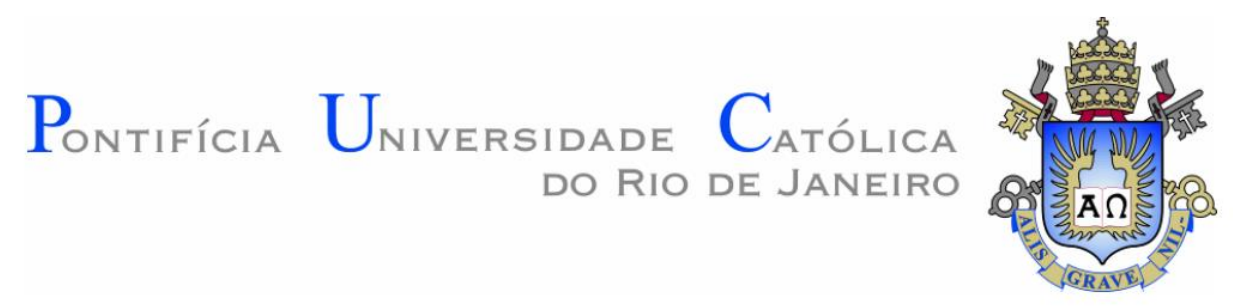

NATÁLIA PINTO REBOUÇAS

\title{
Nadando contra a maré: As práticas estético-político-pedagógicas do MAR
}

\section{Dissertação de Mestrado}

\begin{abstract}
Dissertação de Mestrado apresentada ao Programa de Pós-Graduação em Educação da PUC-Rio como requisito para obtenção do título de Mestre em Educação
\end{abstract}

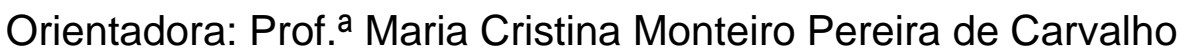


Natália Pinto Rebouças

"Nadando contra a maré: As práticas
estético-político-pedagógicas do MAR"

Dissertação apresentada como requisito parcial para obtenção do grau de Mestre pelo Programa de Pós-graduação em Educação do Departamento de Educação do Centro de Teologia e Ciências Humanas da PUC-Rio. Aprovada pela Comissão Examinadora abaixo assinada.

Profa. Maria Cristina Monteiro Pereira de Carvalho

Orientadora

Departamento de Educação - PUC-Rio

Prof ${ }^{a}$. Maria Helena Marques Araújo UERJ

Profa. Vera Maria Ferrão Candau Departamento de Educação - PUC-Rio

Prof ${ }^{\mathrm{a}}$. Monah Winograd Coordenadora Setorial do Centro de Teologia e Ciências Humanas

PUC-Rio

Rio de Janeiro, 24 de fevereiro de 2021. 
Todos os direitos reservados. A reprodução, total ou parcial, do trabalho é proibida sem autorização da autora, da orientadora e da universidade.

\section{Natália Pinto Rebouças}

Possui graduação em Letras Português/ Inglês pela Universidade Federal do Rio de Janeiro (UFRJ). É integrante do Grupo de Estudo e Pesquisa em Educação, Museu, Cultura e Infância (GEPEMCI) do Departamento de Educação da Pontifícia Universidade Católica do Rio de Janeiro (PUCRio).

Ficha Catalográfica

Rebouças, Natália Pinto

Nadando contra a maré : as práticas estético-políticopedagógicas do MAR / Natália Pinto Rebouças ; orientadora: Maria Cristina Monteiro Pereira de Carvalho. - 2021.

192 f. : il. color. ; $30 \mathrm{~cm}$

Dissertação (mestrado)-Pontifícia Universidade Católica do Rio de Janeiro, Departamento de Educação, 2021.

Inclui bibliografia

1. Educação - Teses. 2. Museu. 3. Decolonialidade. 4. Interculturalidade. 5. Museu de Arte do Rio. I. Carvalho, Maria Cristina Monteiro Pereira de. II. Pontifícia Universidade Católica do Rio de Janeiro. Departamento de Educação. III. Título. 


\section{Agradecimentos}

O presente trabalho foi realizado com o apoio da Coordenação de Aperfeiçoamento de Pessoal de Nível Superior - Brasil (CAPES) - Código de Financiamento 001.

Primeiramente agradeço à PUC-Rio por ter proporcionado toda a estrutura para o desenvolvimento desta dissertação. Sou grata também a todos os professores do programa de pós-graduação em Educação na PUC-Rio, por tudo o que aprendi, em especial a: Maria Inês Marcondes, Mylene Mizrahi, Ralph Bannell, Vera Candau e minha orientadora Cristina Carvalho.

E a todos os professores que vieram antes sem os quais eu não chegaria até aqui, em especial a: Silvia Néli, Nazareth Salutto, Danielle Menezes, Maria Lúcia Guimarães, Mário Martelotta e Marcia Barros (a tia Marcia).

Agradeço ainda à minha mãe Cida e às minhas mães emprestadas, Tuta, Ângela e Derly, por sempre me incentivarem a navegar nas águas turbulentas do conhecimento e da autossuperação.

A Felipe Formoso, por me ajudar a velejar por mares decoloniais.

A Dayane Vieira, Gabriela Campolina, Isabel Gomes, Isabel Mendes, Monique Gewerc, Patrícia Santos e a todos os colegas do GEPEMCI, por me mostrarem as rotas possíveis para navegar.

A minhas parceiras de longa data Cristiane Reis, Fernanda Simones, Juliana Salles e Mônica Linhares, por sempre me ajudarem a remar meu barquinho.

A minhas amigas Ana Luísa Honorato, Érica Nascimento, Paula Costa e Valéria Martins, por me resgatarem em alto mar nos momentos mais difíceis.

A Taís Ximenes, por ser sempre meu porto seguro. 


\section{Resumo}

Rebouças, Natália Pinto; Carvalho, Maria Cristina Monteiro Pereira de (orientadora). Nadando contra a maré: As práticas estético-políticopedagógicas do MAR. Rio de Janeiro, 2021. 183p. Dissertação de Mestrado - Departamento de Educação, Pontifícia Universidade Católica do Rio de Janeiro.

A presente dissertação tem como objetivo traçar um panorama das práticas estético-político-pedagógicas do Museu de Arte do Rio (MAR) por um viés decolonial. Estas práticas, abordadas como estético-político-pedagógicas, se referem às práticas museais como um todo, ou seja, todas as ações empreendidas pelo museu, desde seus aspectos curatoriais até aquilo que compreende o eixo do setor educativo. Ao tratar de práticas estéticas, o presente trabalho assume a estética como espaço epistemológico, ao definir tais práticas como políticas, ressalta o papel crítico e ativista da arte e da educação e, ao interpretar tais práticas como pedagógicas, concebe o museu como um espaço de educação não formal. A investigação teve como metodologia a análise bibliográfica e documental do material produzido pelo museu ou relativo a ele. A partir do panorama traçado, é possível verificar que este museu nada contra a maré porque encontra brechas em um projeto hegemônico, realizando um projeto que pode ser percebido em alguns aspectos como a prática de uma pedagogia decolonial, uma vez que manifesta alternativas ao projeto modernidade/ colonialidade, à história oficial da cidade do Rio de Janeiro e às formas tradicionais de construção de conhecimento.

\section{Palavras-Chave}

Museu; Decolonialidade; Interculturalidade; Museu de Arte do Rio 


\section{Abstract}

Rebouças, Natália Pinto; Carvalho, Maria Cristina Monteiro Pereira de (advisor). Swimming against the tide: The aesthetic-politicalpedagogical practices in MAR. Rio de Janeiro, 2021. 183p. Dissertação de Mestrado - Departamento de Educação, Pontifícia Universidade Católica do Rio de Janeiro.

The objective of this dissertation is to draw a panorama of the aestheticpolitical-pedagogical practices in Museu de Arte do Rio (MAR - Rio Art Museum) in a decolonial perspective. These practices, named as aestheticpolitical-pedagogical, refer to the museum practices as a whole, that is, the actions endeavoured by the institution, from the curatorial aspects to the ones that belong strictly to the educational programme. By dealing with aesthetic practices, the present study assumes the aesthetic as an epistemological field, by defining these practices as political, it highlights the critical and activist role of art and education and, by interpreting such practices as pedagogical, it understands the museum as a non-formal education setting. The research used as a methodology the bibliographic and documentary analysis of the material produced by and about the museum. From the outlined panorama, it is possible to verify that this museum swims against the tide because it finds cracks in a hegemonic project, carrying out a project that can be perceived in some respects as a decolonial pedagogy practice, once it presents alternatives to the modernity/ coloniality project, to the official history of Rio de Janeiro city and to the traditional ways of constructing knowledge.

\section{Keywords}

Museum; Decoloniality; Interculturality; Rio Art Museum 


\section{Sumário}

1. Introdução

2. Referencial Teórico

2.1. Por que falar sobre um museu na Educação? - O museu como espaço de educação não formal

22

2.2. Decolonialidade: Uma busca pela ruptura com

antigos paradigmas

29

2.3. A decolonialidade e o museu

3. Cartograma

3.1. Primeira etapa: Levantamento bibliográfico inicial

3.2. Segunda etapa: Coleta de dados

3.3. MAR à vista - O MAR nos questionários do GEPEMCI 56

3.4. As ondas do MAR online

3.5. As ondas do MAR nos catálogos

3.6. As ondas do MAR na academia e na mídia

4. As práticas estético-político-pedagógicas do MAR

4.1. Surfando dentro da onda: O MAR, suas contradições

e as brechas decoloniais - O Abrigo e o Terreno

4.1.1. Um mergulho no MAR

4.1.2. O amor bandido: A gestão por OS

4.1.3. Um novo museu aporta no Porto Maravilha

4.1.4. O Abrigo e o Terreno

4.1.5. Por dentro da onda: Brechas

4.2. Me ensina a olhar? - A Escola do Olhar e a interculturalidade no MAR - Dja Guata Porã

4.2.1. Todos a bordo! Um MAR de crianças, bebês e de quem mais quiser nadar

4.2.2. "Para o pobre, isso aqui é uma novidade": 
4.2.3. "O Rio de Janeiro continua índio": Dja Guata Porã, um modo outro de fazer museu

4.3. Será que o MAR vai virar sertão? - O MAR em crise e o MAR em tempos de pandemia - Casa Carioca

5. A crença na delicadeza: Notas conclusivas

6. Referências Bibliográficas

6.1. Eventos presenciais

6.2. Obras de arte 181

6.3. Exposições 182

6.4. Vídeos do YouTube 184 


\section{Lista de Siglas e Abreviaturas}

APIB - Articulação dos Povos Indígenas do Brasil

BDTD - Biblioteca Digital Brasileira de Teses e Dissertações

BNDES - Banco Nacional de Desenvolvimento Econômico e Social

CAPES - Coordenação de Aperfeiçoamento de Pessoal de Nível Superior

CCBB - Centro Cultural Banco do Brasil

CEM - Currículo, Espaço, Movimento

CIMI - Conselho Indigenista Missionário

CNPq - Conselho Nacional de Desenvolvimento Científico e Tecnológico

$\mathrm{CPI}$ - Comissão Parlamentar de Inquérito

FRM - Fundação Roberto Marinho

FUNAI - Fundação Nacional do Índio

GEA - Ginásio Experimental de Arte

GEPEMCI - Grupo de Estudo e Pesquisa em Educação, Museu, Cultura e Infância

GT - Grupo de trabalho

IBRAM - Instituto Brasileiro de Museus

ICOM - Conselho Internacional de Museus

IDG - Instituto de Desenvolvimento e Gestão

IFBA - Instituto Federal da Bahia

IHGB - Instituto Histórico e Geográfico Brasileiro

INCRA - Instituto Nacional de Colonização e Reforma Agrária

IPHAN - Instituto do Patrimônio Histórico e Artístico Nacional

MAR - Museu de Arte do Rio

MAM - Museu de Arte Moderna do Rio de Janeiro

MAM-SP - Museu de Arte Moderna de São Paulo

MHN - Museu Histórico Nacional

MIAN - Museu Internacional de Arte Naif

MNBA - Museu Nacional de Belas Artes

OS - Organização social

PEC - Proposta de Emenda Constitucional

PMDB - Partido do Movimento Democrático Brasileiro

PPP - Parceria público-privada 
PT - Partido dos Trabalhadores

PUC-Rio - Pontifícia Universidade Católica do Rio de Janeiro

SciELO - Scientific Electronic Library Online

SPHAN - Serviço do Patrimônio Histórico e Artístico Nacional

STF - Supremo Tribunal Federal

UERJ - Universidade do Estado do Rio de Janeiro

UFF - Universidade Federal Fluminense

UFRGS - Universidade Federal do Rio Grande do Sul

UFRJ - Universidade Federal do Rio de Janeiro

UNESCO - Organização das Nações Unidas para a Educação, a Ciência

e a Cultura

UNIRIO - Universidade Federal do Estado do Rio de Janeiro

UNIVATES - Universidade do Vale do Taquari

UQ - Universidade das Quebradas

USP - Universidade de São Paulo 


\section{Lista de Figuras}

Figura 1: A Redenção de Cam - Modesto Brocos 13

Figura 2: Carolina da Praia de Mauá 2011 e 2016 - Ana Stewart 13

Figura 3: Detalhe de Mining the Museum 42

Figura 4: Detalhe de Black Mirror 42

Figura 5: Vista da exposição O Abrigo e o Terreno, com as obras de Oiticica e Ernesto Neto lado a lado 78

Figura 6: Vista da exposição Turvações Estratigráficas 87

Figura 7: Vista do MAR a partir da Praça Mauá 89

Figura 8: Vista do MAR a partir da Av. Venezuela 89

Figura 9: Vista da Praça Mauá em um dia de sol, a partir do mirante da Escola do Olhar $\quad 92$

Figura 10: Vista da Praça Mauá em um dia de chuva, a partir do mirante da Escola do Olhar 92

Figura 11: Detalhes de Poética do Dissenso 111

Figura 12: Detalhe de Ação 3 - Yuri Firmeza 116

Figura 13: Morrinho - Projeto Morrinho 121

Figura 14: Registro da atividade Bebês no MAR 127

Figura 15: Registro de crianças observando a Praça Mauá, a partir do mirante da Escola do Olhar 129

Figura 16: Retrato de Tia Lúcia $\quad 135$

Figura 17: Registro da mostra A Pequena África e o MAR de Tia Lúcia 135

Figura 18: Detalhe de Cobra do Tempo - Denilson Baniwa 150

Figura 19: Menina na Laje - Claudia Jaguaribe 170 
aqui

nesta pedra

alguém sentou olhando o mar

o mar não parou pra ser olhado

foi mar pra tudo quanto é lado

Paulo Leminski 


\section{Introdução}

Em 2020, contribuí no livro Pedagogias decoloniais e interculturalidade: insurgências (CANDAU, 2020) com um artigo, escrito no ano anterior, intitulado Navegar é preciso: decolonização de saberes no MAR. Nesse artigo, discuto alguns aspectos do projeto curatorial do Museu de Arte do Rio, o MAR, que considero como parte de uma pedagogia decolonial. A pedagogia decolonial pode ser definida como

[...] práticas que abrem caminhos e condições radicalmente "outros" de pensamento, re- e in-surgimento, levantamento e edificação, práticas entendidas pedagogicamente - práticas como pedagogias - que fazem questionar e desafiar a razão única da modernidade ocidental e o poder colonial ainda presente, desviandose dela. (WALSH, 2013, p. 28, tradução nossa).

Assim como Walsh, a referência à pedagogia aqui e naquele artigo não se dá em um sentido instrumentalista, nem em uma restrição ao campo educacional ou aos espaços escolarizados.

O referido artigo é o fruto de um momento inicial de um trabalho que desenvolvi ao longo de dois anos de mestrado na Pontifícia Universidade Católica do Rio de Janeiro (PUC-Rio). A presente dissertação tem como objetivo aprofundar ainda mais o debate ao qual ele deu início. Para tanto, se faz necessário retomar algumas questões.

O artigo é iniciado por uma comparação entre duas obras de arte: $A$ Redenção de Cam de Modesto Brocos e Carolina da Praia de Mauá 2011 e 2016 de Ana Stewart.

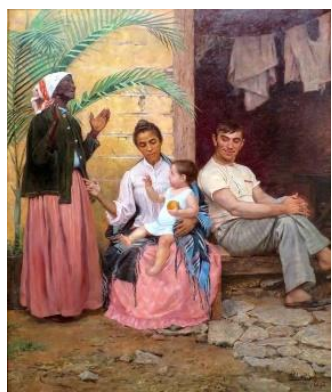

Figura 1: Redenção de Cam - Modesto Brocos

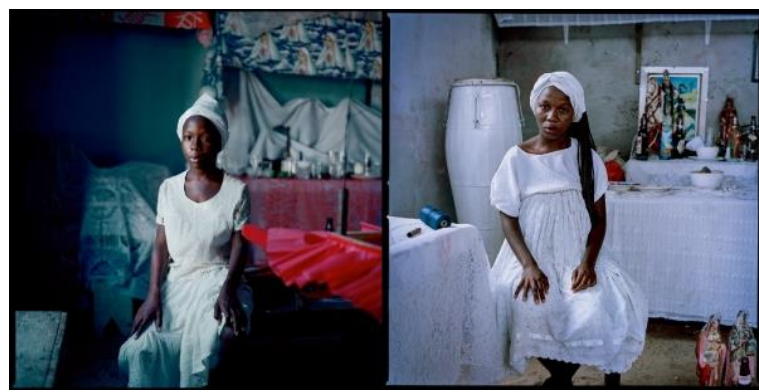

Figura 2: Carolina da Praia de Mauá 2011 e 2016 - Ana Steward 
A primeira faz atualmente parte do acervo do Museu Nacional de Belas Artes (MNBA) e foi utilizada por João Batista Lacerda, antigo diretor do Museu Nacional do Rio de Janeiro, no I Congresso Internacional das Raças, em 1911, para ilustrar a perspectiva da mestiçagem como estratégia para o branqueamento da população brasileira, por ele defendida (SCHWARCZ, 1993). Nela, vemos uma senhora negra e de pele com tonalidade bem escura, de pé, com as mãos erguidas, como quem agradece a Deus. Sentada ao seu lado, se encontra uma mulher mais nova e de pele um pouco mais clara. No colo da mulher sentada, está um bebê de pele branca. Ao lado dos dois, está um homem branco, de feições tipicamente europeias. A pintura parece representar a felicidade de uma família em se "salvar" - por isso, o nome "Redenção" - pelo branqueamento de sua pele ao longo das gerações.

A segunda obra, Carolina da Praia de Mauá 2011 e 2016, fez parte da exposição Mulheres na Coleção MAR ${ }^{l}$, ocorrida entre novembro de 2018 e novembro de 2019 no MAR e faz parte do acervo do museu. Trata-se de uma ampliação fotográfica de duas fotos de uma jovem posicionada no mesmo local de sua casa, uma tirada em 2011 e outra, em 2016. Na foto da esquerda, de 2011, vemos uma jovem sentada em uma cadeira, vestida de branco e com a cabeça, aparentemente sem cabelos, envolta em um lenço branco, fazendo uma espécie de turbante. Do seu lado direito, há uma mesa de madeira descoberta e, do lado esquerdo, outra mesa. Atrás dessa mesa, há um objeto que parece ser uma garrafa de cerveja. E um pouco mais ao fundo, podemos ver algumas imagens de Nossa Senhora, em um pano azul pendurado sobre uma prateleira. Abaixo da prateleira, há um móvel coberto com um pano vermelho, com alguns objetos sob um pano branco e, na frente deles, alguns copos de vidro. Ao lado desse móvel, há outro móvel menor sob um plástico branco. Na foto da direita, de 2016, vemos a mesma jovem na mesma posição. Dessa vez, ela está vestida de branco, com os cabelos longos em tranças finas, que saem por trás de um pano branco que envolve a sua cabeça. A mesa de madeira permanece no seu lado direito, mas agora está coberta por um pano branco. A mesa que estaria do seu lado esquerdo já não se encontra no ambiente. No lugar dela, vemos estatuetas de dois santos com cera de vela escorrendo sobre suas cabeças. Na frente deles, há uma garrafa de cerveja. Ao

\footnotetext{
${ }^{1}$ Mulheres na Coleção MAR (11/2018 - 11/2019) - curadoria coletiva da equipe MAR.
} 
fundo, a prateleira onde antes estava o pano com imagens de Nossa Senhora agora estava coberta por um pano branco. O móvel abaixo dela também está coberto por um pano branco, e os objetos sobre ele agora são estatuetas de santos e garrafas de cerveja. Ao lado desse móvel, há um tambor típico de celebrações de religiões de matriz africana, também todo branco. A leitura da imagem, da esquerda para a direita, mostra uma $i a \hat{o}^{2}$ no início e fim de seu processo de feitura.

Traçando uma comparação entre as duas obras, é possível perceber, de um lado, um distanciamento do negro em relação a uma identidade africana, em um encaminhamento à branquitude, e, de outro, uma personagem que mergulha em uma identificação cultural associada à África e à negritude, se empoderando pela afirmação de sua etnicidade.

Como será discutido com mais profundidade adiante, há muitos eixos em que o MAR, onde está a segunda obra, e o MNBA, onde está a primeira, se encontram, em muitas comparações feitas pelo próprio MAR. No evento denominado \#MAR $e^{3}$, realizado em fevereiro de 2020, em comemoração aos sete anos do MAR, Marcelo Araújo, diretor da Japan House, em São Paulo, um dos participantes do encontro, comparou a trajetória de Paulo Herkenhoff, primeiro diretor cultural e primeiro curador-chefe do MAR, no próprio MAR e no MNBA, onde havia atuado anteriormente. Araújo destacou que o modelo de gestão por organização social (OS) do MAR permitiu a Herkenhoff maior liberdade de ação e organização de um projeto curatorial que não conseguiu realizar anteriormente no MNBA, devido ao tipo de gestão deste museu. Em uma das edições do evento Conversa de Galeria 4 , no MAR, ocorrida em 2013, o artista Ernesto Neto, que já teve diversas obras expostas e até mesmo comissionadas por este museu, também compara o MAR com o MNBA. O artista critica o MNBA, em uma referência ao fato de ser um museu ligado a uma tradição de arte europeia, caracterizando-o como "um museu sem expressividade na nossa cultura" e afirma ainda que este

\footnotetext{
${ }^{2}$ No candomblé, aqueles que experienciam a possessão passam por um processo chamado "feitura". Antes da iniciação, são chamados de abians. Ao longo da feitura, quando estão cumprindo os sete anos de obrigação, são chamados iaôs. É comum aos iaôs terem que raspar o cabelo. Com a feitura completa, os iaôs passam a ser chamados de ebomis (RABELO, 2015).

${ }^{3}$ MUSEU DE ARTE DO RIO. \#MARé. Rio de Janeiro: Museu de Arte do Rio (MAR), 12 fev. 2020.

${ }^{4}$ MUSEU DE ARTE DO RIO. Conversa de Galeria com Ernesto Neto - Especial de encerramento $\boldsymbol{O}$ Abrigo e o Terreno. 05 ago. 2013. (30m37s). Disponível em: https://youtu.be/VNT0GOZv1GE. Acesso em: 29 out. 2019.
} 
deveria ser um museu em que aprendemos sobre a nossa arte. Traçando um paralelo com a educação escolar tradicional, o artista diz que a educação deveria nos ajudar a entender quem somos e não quem gostaríamos de ser. Em relação ao MAR, o artista afirma o desejo de que este seja um museu que nos una como sociedade e que faça com que nos amemos como nós somos. Esse desejo é expresso pelo nome de sua obra exposta em uma das primeiras exposições ${ }^{5}$ do museu, Mar revolto é coisa do passado, mar tranquilo é mar nunca navegado, no qual faz o convite para que o MAR seja visto como esse "mar nunca navegado" e que, por isso mesmo, pode ser apropriado e transformado em qualquer coisa.

A fala de Ernesto Neto pode dialogar com a análise feita anteriormente sobre as duas obras de arte. No lugar de nos rendermos a um projeto de sociedade embranquecida e europeizada, como em A Redenção de Cam, encontrarmos a nós mesmos, mergulharmos em nossa essência, como faz Carolina da praia de Mauá, no que há de mais brasileiro ${ }^{6}$ em nós mesmos, e também no que há de mais carioca.

Apesar de muitos paralelos que podem ainda ser traçados entre os dois museus, o ponto que se pretende levantar aqui é o de que o MAR aparenta seguir em uma direção contrária ao que se concebe tradicionalmente como prática museal. Além de regimes de representação que rompem com o quadro de referências tradicional dos museus, branco e europeu, circulam pelo MAR saberes que subvertem lógicas epistêmicas coloniais/ modernas/ eurocêntricas. O título desta dissertação fala em nadar contra a maré, porque o MAR evidencia um potencial que sugere contranarrativas ao projeto modernidade/ colonialidade e também à história oficial da cidade do Rio de Janeiro.

O objetivo desta dissertação é traçar um panorama das práticas estéticopolítico-pedagógicas do MAR a partir da perspectiva decolonial, conforme é elaborada por autores como Mignolo, Quijano, Walsh, entre outros. Cabe esclarecer o que são essas práticas e por que são abordadas como estético-político-

\footnotetext{
${ }^{5}$ O Abrigo e o Terreno (03/2013 - 07/2013), curadoria de Paulo Herkenhoff e Clarissa Diniz.

${ }^{6}$ Embora não haja uma concordância entre os estudiosos das culturas afro-brasileiras e da história dos africanos e afro-brasileiros sobre como se deu surgimento dos primeiros terreiros de candomblé e de umbanda ou até mesmo de qual seria o primeiro terreiro, os que se dedicam a estas temáticas estão de acordo que estas religiões nasceram no Brasil e estão vinculadas diretamente à história da diáspora africana. São religiões, portanto, brasileiras de matriz africana (cf. MOURA, 1995; GOLDMAN, 2011).
} 
pedagógicas. Refiro-me às práticas museais como um todo, isto é, todas as ações empreendidas pelo museu, desde seus aspectos curatoriais até aquilo que compreende o eixo do setor educativo. Primeiramente, tratar de práticas estéticas significa afirmar a estética como espaço epistemológico (MIGNOLO, 2019). Além disso, definir tais práticas como políticas constitui ressaltar o papel crítico e ativista da arte e da educação. Por fim, interpretar tais práticas como pedagógicas é conceber o museu como um espaço de educação não formal, além de ser ainda um espaço de potencial desaprendizagem e reaprendizagem.

A declaração de que a dissertação tratará das "práticas museais como um todo" traz o risco da compreensão de que se tenha a pretensão de abordar cada aspecto mínimo do MAR em detalhe, o que não seria possível, uma vez que toda pesquisa possui seus limites. $\mathrm{O}$ “todo" aqui se refere ao fato de que não haverá um enfoque em um elemento específico do museu, como o setor educativo, por exemplo. A partir do que o material mostra, o olhar ampliará um ou outro aspecto, uma ou outra fala, obra ou exposição, de maneira que se tornem visíveis as práticas estético-político-pedagógicas do museu, atingindo-se o objetivo de obter seu panorama ${ }^{7}$.

A presente investigação se vincula ao Grupo de Estudo e Pesquisa em Educação, Museu, Cultura e Infância (GEPEMCI), coordenado pela professora Cristina Carvalho, que, desde 2010, investiga questões relativas aos espaços museais e suas estratégias educativas. A linha de pesquisa dentro do grupo a qual a investigação se insere é a Educação em Museus, que toma o museu como espaço de educação não formal enquanto seu pressuposto. Dentro do curso de Pósgraduação em educação da PUC-Rio, a pesquisa está vinculada à linha de pesquisa Diferenças Culturais, Espaços de Formação e Processos Educativos.

A dissertação se desenvolve da seguinte maneira: Primeiramente, faço uma revisão teórica dos eixos sobre os quais se dará o trabalho posterior de análise, sendo eles: (1) o museu como espaço de educação não formal; (2) a perspectiva decolonial; (3) a decolonialidade no museu. O item seguinte se refere aos aspectos

\footnotetext{
${ }^{7}$ De acordo com o dicionário Michaelis, a palavra "panorama" possui dois sentidos literais: "1. Grande quadro circular disposto de modo que o espectador, colocado no centro, veja os objetos representados como se estivesse em um local bem alto, dominando todo o horizonte em volta; 2 . Visão extensa e abrangente, em todas as direções, que se desfruta de um local geralmente alto; paisagem, vista". Em sentido figurado, segundo o mesmo dicionário, a palavra pode significar: "3. Estudo ou apresentação completa e ampla de determinado assunto; 4. Grande exposição".
} 
metodológicos, no qual apresento como foi realizada a pesquisa. Em um primeiro momento dentro deste mesmo item, delineio o MAR dentro do cenário dos museus do Rio de Janeiro, a partir dos achados dos questionários que o GEPEMCI aplicou em dois períodos, entre os anos de 2015 e 2016 e entre 2019 e 2020. Em um segundo momento, os dados encontrados a partir do material coletado são separados em categorias e analisados. Posteriormente, apresento a discussão dos dados, separados a partir dos temas mais recorrentes e que retratam de maneira mais explícita as práticas do MAR. Dentro da discussão, trago uma exposição que já ocorreu no museu para ilustrar cada aspecto ressaltado. Por fim, encaminho a conclusão, apontando questões ainda a serem exploradas em trabalhos futuros.

Esta pesquisa possui como principal objetivo:

- Traçar um panorama das práticas estético-político-pedagógicas do MAR a partir da perspectiva decolonial

A pesquisa busca responder às seguintes questões:

- O MAR pode ser compreendido dentro de um projeto ético-político e epistêmico de decolonização?

- Quais são as práticas estético-político-pedagógicas do MAR que se destacam e em que medida podem ser consideradas transgressoras de uma lógica colonial e instauradoras de uma práxis outra?

Partindo das questões supracitadas, foram estabelecidos os seguintes objetivos específicos:

- Mapear as práticas do MAR que apresentem caráter insurgente e decolonial;

- Analisar a articulação entre as dimensões estética, política e pedagógica do museu;

- Verificar as estratégias adotadas pelo museu para dar visibilidade a segmentos subalternizados e para questões tradicionalmente silenciadas.

Concebendo o museu enquanto espaço de educação não formal e também enquanto local privilegiado para legitimação de discursos, o presente trabalho busca discutir esta instituição dentro da matriz colonial, considerando a possibilidade de uma prática museal decolonial. O caminho escolhido foi 
debruçar-se sobre a prática pedagógica do MAR enquanto "exercícios radicais de des-pensar, des-disciplinar e re-educar" (MALDONADO-TORRES, em entrevista para DREXLER-DREIS, 2014). O que confere relevância ao que se propõe é a busca por mapear um projeto de desobediência epistêmica através da arte como uma instância daquilo que é defendido por pensadores e ativistas da América Latina, um "giro decolonial", entendido como um projeto ético-político e epistêmico de desvinculação de estruturas coloniais.

A fim de responder aos objetivos previamente colocados, a pesquisa foi realizada em uma abordagem qualitativa de caráter descritivo e exploratório, a ser descrita em detalhes no terceiro capítulo. Optou-se como metodologia pela análise bibliográfica e documental do material produzido pelo museu ou relativo a ele.

Cabe sinalizar algumas razões para a escolha da análise bibliográfica e documental como metodologia de pesquisa. O primeiro motivo já mostrou sua relevância, em 2019, no momento de elaboração do projeto. O MAR passava então por um momento de instabilidade, que será relatado de modo mais detalhado no item 4.3. Ao longo do ano de 2019, muitas notícias foram veiculadas na mídia afirmando que o museu poderia fechar em breve devido à falta de repasse de verbas da prefeitura para a OS com a qual divide a gestão. Em novembro do mesmo ano, Evandro Salles, então diretor-cultural do MAR, pediu demissão, alegando como motivo o "profundo desmantelamento" dos equipamentos culturais da cidade por parte do então prefeito do Rio de Janeiro (cf. HONORATO, 2019; FREIRE, 2019; ANGIOLILLO, 2019). Portanto, uma vez que figuras-chave do MAR estavam deixando a equipe do museu, assim como as instituições vinculadas a ele estavam sob a ameaça de perderem este vínculo, não existia na época de planejamento da pesquisa a garantia de que o museu se manteria aberto ao longo do desenvolvimento da mesma e nem de que ele seguiria a mesma linha de curadoria e de projetos de educação que vinha seguindo desde sua inauguração. Em seguida, outro motivo surgiu para reafirmar a escolha dessa metodologia como a única possível: a entrada no Brasil da pandemia de covid$19^{8}$, no início de 2020, que forçou o fechamento dos museus. O MAR se manteve

\footnotetext{
${ }^{8}$ Em 2020, o coronavírus da síndrome respiratória aguda grave 2 (SARS-Cov2), identificado pela primeira vez em dezembro de 2019 na China, se espalhou pelo mundo, ocasionando uma pandemia da doença que recebeu o nome de covid-19. A doença causa problemas respiratórios que, em casos mais graves, podem levar à morte. O primeiro caso de covid-19 no Brasil foi
} 
fechado desde o dia 16 de março, sem data prevista para reabertura. O museu só reabriu para visitação em 22 de setembro. No entanto, para visitar as exposições em cartaz era então necessário agendar o dia e o horário pelo site. O número máximo de inscrições por cada faixa de horário era de 60. Até dezembro de 2020, o MAR ainda não havia voltado às suas atividades presenciais normalmente.

diagnosticado em fevereiro de 2020 e a primeira morte, em março. Como não há uma vacina para a doença, a forma de prevenção mais utilizada ao redor do mundo, recomendada pela Organização Mundial de Saúde (OMS), é o isolamento social. A adoção dessa medida causou o fechamento de vários estabelecimentos durante um longo período, em respeito a medidas impostas pelos governos ou por consciência própria das gestões dos espaços (WORLD HEALTH ORGANIZATION). 


\section{2 \\ Referencial Teórico}

Esta pesquisa gira em torno de três eixos centrais, cujas teorias e perspectivas nas quais estão ancorados são elucidadas nos próximos subcapítulos. Os eixos são:

- O museu enquanto espaço de educação não formal.

- A decolonialidade

- A possibilidade de o museu compor parte de um projeto decolonial, realizando o que Catherine Walsh chama de "pedagogia decolonial".

A pergunta que abre o título do primeiro subcapítulo, "Por que falar sobre um museu na Educação?", parte de uma inquietação que me acompanhou ao longo desses dois anos de mestrado. Um mestrado na área de educação traz a nossas mentes uma temática relacionada à escola. De fato, ingressei no curso pensando em realizar uma pesquisa sobre escola. $\mathrm{O}$ contato com minha orientadora, Cristina Carvalho, e as discussões que tive na disciplina Espaços de Educação Não-Formal, ministrada por ela, foi o que despertou meu interesse pela educação chamada não formal, modalidade dentro da qual o museu se encaixa. Assim, o subcapítulo a seguir indica não só em qual referencial teórico em relação ao museu e à educação não formal esta pesquisa se apoiou, como também busca justificar trazer o museu em um mestrado de educação e até mesmo explicitar em que medida uma pesquisa sobre um museu poderia contribuir para pensar não só a educação de maneira geral, como também pensar na educação escolar.

Nos dois outros subcapítulos, é discutida a perspectiva decolonial. Primeiramente, são explicitados em que consiste esta perspectiva, seus principais autores e alguns pontos de maior destaque dentro dela. Em seguida, são apresentadas algumas reflexões teóricas que ligam a discussão decolonial ao museu e à arte. 


\section{1 \\ Por que falar sobre um museu na Educação? - O museu como espaço de educação não formal}

A educação é uma prática social complexa, multiforme, permanente, por isso ela não acontece só na escola, mas também nas bibliotecas, nos museus, nos cinemas, com a televisão, a internet, com a família, no clube, no bairro, com a vizinhança etc. (ARAÚJO, 2012, p. 86).

É comum que ao falar de educação se pense na escola. Entretanto, a educação escolar é apenas um tipo de educação. Conforme afirma Trilla (2008), o processo educacional é amplo e variado, podendo-se classificar dentro dele alguns tipos de educação e até mesmo a preponderância de um deles sobre os demais. Comumente, se distinguem três tipos de educação: a formal, a não formal e a informal. Como assegura Araújo (2012), com base em Trilla (2008) e Gohn (2010), enquanto a educação informal é aquela que está envolta no cotidiano e em sua espontaneidade, a formal e a não formal são permeadas de intencionalidade e possuem caráter propositivo, não espontâneo.

De acordo com Trilla (2008), a associação entre educação e escolarização data do século XIX. Além da escola, existem outros mecanismos educacionais, que, por vezes, podem interferir na ação escolar, seja acrescendo-se a ela, seja constituindo um contraponto. Para Ghanem (2008), a certificação é a característica fundamental da educação formal. A identificação entre educação e escolarização surgiria então do reconhecimento formal desta última por parte do Estado.

Quanto à educação não formal, em termos gerais, Trilla (2008) a define como todo processo educacional que não surge da família, nem do contato direto com o mundo em experimentações sem intenção prioritariamente educativa, nem é proveniente do sistema escolar. Para o autor, a educação não formal ela é entendida principalmente pelo contraponto que faz com aquilo que nega, isto é, a educação formal. Trilla (2008) diz ainda que existem certos tipos de interações entre a educação formal e a não formal. $O$ autor cita relações de complementaridade, de suplência ou substituição, de reforço e colaboração e de interferência ou contradição.

O museu é considerado uma instituição pertencente ao campo da educação não formal. No entanto, a função primordial do museu não é a educativa, mas sim, segundo Oleiro (2005), a de coleta, resguardo, garantia e conservação de 
patrimônios e testemunhos. As funções educativas e sociais foram se agregando mais tardiamente na história desta instituição, quando o museu deixou de ser uma instituição voltada a si mesma e se abriu para o exterior. Posteriormente, foram somados desafios contemporâneos que fizeram com que esta instituição revisse sua organização, sua relação com a sociedade, a formação de suas coleções e sua maneira de se fazer ser vista.

Varine (2012) aponta como principais funções atribuídas ao museu ao longo de sua história: seu papel em relação à pesquisa, à conservação, à educação e ao deleite estético e intelectual, seu uso turístico e, por fim, sua associação ao nacionalismo e à ideologia dominante. $\mathrm{O}$ autor considera que é possível a esta instituição ser ressignificada como "um instrumento útil e eficaz de informação, de educação, de mobilização a serviço do desenvolvimento local" (VARINE, 2012, p. 172).

Em relação às mudanças ocorridas nos museus ao longo da história, Semedo (2005) se refere à maneira como foram construídos os discursos sobre museus, sobre seus acervos e suas funções, sobre o próprio patrimônio, o valor conferido a ele e à maneira de abordá-lo. Nesse sentido, atualmente os museus veem sua ação como um esforço de conjugar a guarda, a conservação e o estudo de seus objetos com diferentes formas de produção de conhecimento, suscitando interpretações e sensações, de maneira a trazê-los à luz das críticas contemporâneas, retirando-os de seu estatuto hegemônico, que remete ao limiar da ideia de patrimônio e museu.

Como aponta Padró (2005), atualmente, com a contribuição dos estudos culturais, vive-se uma fase em que o cânone e a narrativa hegemônica, patriarcal e colonial dentro dos espaços museais têm sido questionados. Segundo Brito (2005), o crescimento e as mudanças dos museus com coleções não europeias, em países que foram colonizados, afetaram a legitimidade do museu tradicional. Os sentidos e as práticas do museu precisaram ser reformulados para a afirmação desses povos saídos de uma relação de dominação. Esse movimento fez com que surgisse uma atitude reivindicatória do retorno dos objetos tirados destes lugares e também a criação de vários tipos de manobras para possibilitar o acesso a este acervo. Nesse sentido, Brito (2005) ressalta que o discurso museal se voltou à questão da territorialidade e à construção identitária.

Machado (2012) destaca, entre os múltiplos papéis que o museu possui perante a sociedade contemporânea, o de responsabilidade social. Para a autora, o 
museu tem um potencial para a promoção do desenvolvimento local. Segundo a autora, enquanto instituição sociocultural e educativa, o museu não pode se desvincular do território onde se localiza, nem ser alheio à sua vizinhança. Conforme ressalta Machado (2012, p. 73), a relação entre vizinhos, mais do que uma coexistência em proximidade, é uma "partilha de identidades, de objetivos e expectativas, de espaços e recursos, de fragilidades e potencialidades".

De acordo com Lopes (2005), o museu é uma instituição que foi elevada à condição de discurso oficial, cumprindo um papel em legitimar a construção das memórias, delinear a erudição, estipular o patrimônio e elaborar a narrativa de uma sociedade específica. Ainda conforme ressalta o autor, na contemporaneidade, as sociedades pós-coloniais vêm denunciando o espaço museal pela sua pretensa neutralidade, e afirmando o desafio de criação de políticas culturais que busquem uma narrativa mais plural.

Na América Latina, segundo Araújo (2012), os museus nacionais surgem afirmando as identidades que se formam no processo de independência. Para a autora, ao longo do tempo, os museus foram consolidando suas funções enquanto instituições de pesquisa e ensino, reforçando sua identidade como espaços de educação não formal.

Esse movimento de renovação no campo museal, como visto em Varine (2012), se tornou mais intenso na década de 1960, e acabou originando o que é conhecido como a Nova Museologia. Ainda segundo o autor, México, Índia e Nigéria lideraram esse movimento, que foi também influenciado pela mobilização de afirmação étnica dos Estados Unidos. A Nova Museologia foi se desdobrando em um "duplo movimento de museologia turística e de museologia popular" (VARINE, 2012, p. 181). Ela reúne diferentes tipos de agentes que procuram adequar o museu às necessidades contemporâneas e às populações locais. Conforme afirma Araújo (2012, p. 74), com base em Fernandes (1999), a Nova Museologia é uma nova ideologia de trabalho museal, que tem como parâmetros:

Democracia cultural (respeito à diversidade cultural e valorização da própria cultura de cada grupo); novo paradigma (da monodisciplinaridade à multidisciplinaridade, do público à comunidade, do edifício ao território); conscientização da comunidade da existência e valor de sua própria cultura; modelo museológico aberto e interativo, tendo por objeto o patrimônio originado da comunidade; diálogo com os sujeitos, com a participação ativa da comunidade, catalizando as necessidades da mesma; método colocado na exposição, ou seja, a 
exposição passa a ser um método como um dos mais importantes instrumentos de diálogo e conscientização.

Dentro deste movimento, segundo Araújo (2012), surge o ecomuseu, um tipo de museu orientado por tal ideologia. Esse tipo de museu tem como elemento fundamental a tríade "território-patrimônio-comunidade". No ecomuseu, a comunidade local ganha protagonismo, não há edifício nem coleção, mas sim a valorização do patrimônio regional e a própria região.

A autora aborda também o fato de que os museus vão se instituindo como espaços que concretizam juízos de valor e que desenham identidades e alteridades. Os museus de história, por exemplo, escolhem um discurso sobre os eventos históricos, selecionam os fatos que querem evidenciar e, ao mesmo tempo, deixam parte da história de fora, conferem protagonismos a determinados agentes, enquanto outros são invisibilizados ou marginalizados. Já os museus de arte, a partir da escolha do que compõe e do que fica fora de seu acervo, ditam o que é belo, o que é arte, o que é digno de entrar no museu e o que não é. Assim, o museu diz muito através do que expõe, mas também através do que deixa de expor.

Devido a isso, Araújo (2012) ressalta o elo entre os museus e a memória. Contextualiza ainda que os ecomuseus e os museus comunitários têm seus sentidos muito aproximados, sendo interpretados por alguns autores até mesmo como um único tipo de museu, porque ambos surgiram a partir de demandas de movimentos sociais em busca de um senso de justiça para a recuperação de memórias e do resgate da história de comunidades historicamente subalternizadas. No entanto, a autora pontua algumas diferenças afirmando que o ecomuseu é um museu territorial em seu todo, ou seja, não possui uma sede, já o museu comunitário, embora lide com o território em que é localizado como temática e que dê protagonismo para a comunidade ao redor, possui uma sede e é nela que os elementos que narram a história e retratam a identidade desse território e de sua comunidade são expostos.

A questão da recuperação da memória, conforme discute Araújo (2012), está diretamente ligada a uma concepção de museu voltado para fora e para o desenvolvimento humano e comunitário. Trata-se de uma necessidade da comunidade de compreender a si mesma para que se conscientize e que abra para si possibilidades de transformação. Como aponta a autora, é uma concepção muito 
próxima da discussão promovida por Paulo Freire, que, não por acaso, foi convidado para a Mesa Redonda de Santiago do Chile de 1972, porém, foi impedido de comparecer pelo regime militar brasileiro.

A Mesa-Redonda de Santiago do Chile, em 1972, organizada pelo Conselho Internacional dos Museus (ICOM) em parceria com a Organização das Nações Unidas para a Educação, a Ciência e a Cultura (UNESCO), é o marco para o surgimento da proposta de um museu "para todos" e também das orientações do movimento para uma Nova Museologia. Diversos grupos, como de ecologistas e socialistas, colaboraram para o debate, no qual entrou também a reivindicação de devolução dos bens usurpados ou expatriados de países que saíram da condição de colônia e que buscam encontrar seu protagonismo na História (SANTOS, 2008).

Para Dalla Zen (2011), o convite a Paulo Freire para participar da Mesa de Santiago tinha significado em relação às ideias que orientaram o evento: conscientização, engajamento social e político e compromisso com um projeto de sociedade diferente. A ideia, segundo a autora, é que os museus, que já eram "espaços de educação", passassem a ser "espaços democráticos de educação". Democratizar significa estar aberto, acessível e compreensível a qualquer tipo de público, inclusive a um público que jamais tenha frequentado a instituição anteriormente. Para tanto, os museus precisaram criar recursos que os tornassem acessíveis. Isto se estende desde recursos que visem à acessibilidade física do lugar quanto a programas educativos e materiais didáticos. Segundo Dalla Zen (2011), a proporção de recursos democráticos oferecidos ao público indicaria o quanto um museu é democrático. Desta maneira, conforme afirma a autora, o conceito de "pedagógico" e as aspirações democráticas se tornam cada vez mais entrelaçados. E, em relação à abertura a um público leigo, de acordo com a autora, o museu de arte se configurou como o de maior resistência, pois, como assinala, não seria fácil para a "casa das musas" se tornar a "casa do povo".

Segundo Dalla Zen (2011), a compreensão do museu como uma instituição educativa ocorre concomitantemente com o processo de ressignificação do próprio campo da arte, que se volta a um diálogo cada vez mais profundo com o público, chegando até mesmo a envolvê-lo na concepção das obras. "Tanto as manifestações artísticas atuais, como as teorias contemporâneas de educação, operam na produção de um sujeito participante" (DALLA ZEN, 2011, p. 73). Com diferentes sujeitos e diversas formas de engajamento entre eles, a obra vai 
transpondo seus limites, se interdisciplinarizando. Dalla Zen (2011) conclui que os conceitos de "participação" e "interdisciplinaridade" são fundamentais à arte feita atualmente.

Valente (2009) também comenta a respeito da associação no museu entre a sua função educativa e a sua democratização. Toda exposição quer dizer algo e democratizar a compreensão dessa mensagem envolve um processo de aprendizagem. Para Hooper-Greenhill (1994 apud VALENTE, 2009), existem dois tipos principais de abordagens comunicativas utilizadas nas exposições: a transmissora e a cultural. A primeira concebe que aquilo que se quer comunicar parte de uma fonte e chega a um receptor passivo, em um caminho linear, fechado e até mesmo autoritário. A segunda considera o processo como uma negociação, na qual os indivíduos se engajam e utilizam suas próprias vivências para a construção de sentido.

O entrelaçamento entre o pedagógico e o democrático fez ainda com que a relação entre o museu e a escola se estreitassem cada vez mais. Segundo Dalla Zen (2011), embora o museu e a escola tenham origens bem distintas, são instituições com muito em comum. Inicialmente, ambas são instituições modernas. Enquanto a primeira se voltou à preservação do patrimônio e estipulou o modelo do que deve ser valorizado, a segunda incumbiu-se da fixação de hábitos e definiu ideais de normalização. De acordo com a autora, levou mais de dois séculos para que as duas instituições tivessem seus caminhos cruzados e, quando isto ocorreu, a forma-escola prevaleceu, instituindo o dispositivo escolarizador.

Para Dalla Zen (2011), escolarizar se impôs de maneira tão forte enquanto regra no museu que o investimento em atração de público e comunicação dentro destes espaços passou a dar prioridade ao público escolar.

O museu se parece cada vez mais com a escola: programas pedagógicos, materiais didáticos, visitas educativas, formação de professores; todas essas expressões fazem parte, hoje, do campo semântico da palavra museu. Campo semântico que, certamente, não é o mesmo da época em que a burguesia revolucionária, imbuída de ideais republicanos e democráticos, julgava fundamental a abertura dos museus ao público em geral, ou melhor, ao público burguês. Vale lembrar que foi nesse período, também, que se deu à escola um caráter universal, como forma de socializar a criança e prepará-la para exercer as funções produtivas do mundo adulto. Desde então, museu e escola, cada qual ao seu modo, legitimaram-se como instituições modernas a "serviço da nação". (DALLA ZEN, 2011, p. 60). 
Valente (2009) defende que o museu busque uma atuação diferente do formato curricular da escola. É necessário que estes espaços de educação percebam suas diferenças, "não porque essas instituições correspondessem a níveis hierárquicos de educação, mas porque são instâncias de naturezas educativas diferentes" (VALENTE, 2009, p. 93). A autora destaca, em relação ao eixo educativo do museu, a dificuldade em reconhecer-se a abrangência do conceito de educação, restringindo-o ao ensino e à escola. A autora sinaliza que esta limitação do conceito acarreta o entendimento da dimensão educativa dos museus apenas em relação ao seu potencial de complementar a escola ou auxiliála em suas deficiências. O debate em torno desse eixo permeia até mesmo a concepção das exposições. Conforme aponta Valente (2009), existe um impasse também entre os curadores em relação à obrigatoriedade de objetivos educativos nas exposições.

Apesar do debate em torno de uma tarefa educativa dos museus e de um setor dentro deles, é essencial frisar que mesmo no cumprimento de suas

[...] funções elementares de conservar e mostrar um patrimônio tangível ou intangível ele [o museu] está gerando efeitos educativos. Nesse sentido, independentemente de contar ou não com um programa específico de atividades pedagógicas, a instituição é em si mesma um meio educativo. (VALENTE, 2009, p. 88).

Por fim, quanto às mudanças na concepção e na atuação dos museus, dentro da questão do relevo que vem ganhando sua função educativa em relação ao seu processo de democratização, cabe destacar, conforme discute Dalla Zen (2011), que a associação entre cultura e cidadania acarreta um contexto marcado pela tensão entre arte e mercado, no qual é possível notar a ocorrência de dois tipos de discursos: uma concepção de acessibilidade à arte influenciada pela pedagogia libertadora freireana e a imagem da privatização da cultura e da crescente responsabilização social das empresas como o que possibilita a adoção de estratégias democratizantes. Segundo Dalla Zen (2011), mecanismos de privatização da cultura são criados devido ao reconhecimento, principalmente por parte das políticas públicas de cultura, da função social dos museus, que passam a significar para a iniciativa privada um meio de desempenhar sua responsabilidade social. 


\section{2 Decolonialidade: Uma busca pela ruptura com antigos paradigmas}

Os estudos decoloniais focam na experiência histórica da América Latina para realizar uma revisão da modernidade, concebida como tendo um outro lado, a colonialidade. A ideia básica de tais estudos é a de que o colonialismo teve seu fim, mas deixou como vestígio a colonialidade, padrão de poder que se conservou após o fim do colonialismo e possibilitou a constituição do sistema/ mundo moderno (ARIAS et al., 2012). O colonialismo pode ser definido como uma relação política e econômica de soberania de um povo sobre outro e a colonialidade como

um padrão de poder que emergiu como resultado do colonialismo moderno, mas que em vez de estar limitado a uma relação formal de poder entre dois povos ou nações, se refere à forma como o trabalho, o conhecimento, a autoridade e as relações intersubjetivas se articulam entre si, através do mercado capitalista mundial e da ideia de raça. (MALDONADO-TORRES, 2007, p. 131, tradução nossa).

Esse padrão, segundo Maldonado-Torres (2007), não é formado a partir de qualquer tipo de relação colonial, mas sim daquela que se constituiu com a conquista da América, momento em que se configuraram a mais ambiciosa empresa colonial da história e também a articulação entre o capitalismo e as formas de dominação, que conservaram e apoiaram o controle sobre sujeitos colonizados.

Devido a este resquício deixado pelas relações coloniais, as nações latinoamericanas, embora emancipadas no âmbito administrativo de seus colonizadores europeus, são impossibilitadas de alcançar uma democratização real, porque foram fundadas sob um modelo de estratificação sociorracial que colocou determinados grupos humanos em uma posição de extrema vantagem frente aos demais, que por sua vez, apesar de constituírem a maioria populacional, tiveram seu acesso ao controle dos meios de produção negado (ARIAS et al., 2012). Segundo Mignolo (2017), a colonialidade é o monstro de quatro cabeças e duas pernas, criado pelo colonialismo. As quatro cabeças são formadas pelo controle da economia, da autoridade, do gênero e da sexualidade e pelo controle do conhecimento e da subjetividade. Já as duas pernas do monstro, ou seja, a sua base, são o racismo e o patriarcado. 
Um conceito central para os estudos decoloniais é a colonialidade do poder, elaborado pelo sociólogo Aníbal Quijano. Conforme afirma Quijano (2000), a colonialidade do poder se refere a um novo padrão de poder a nível global formado dentro da experiência histórica de conquista da América Latina.

De acordo com Quijano (2000), a experiência de dominação colonial europeia encontrou seu fundamento na ideia de raça, que constituiu o instrumento mais eficiente para a imposição do padrão de poder mundial. Antes da colonização da América, a "raça" não era concebida da mesma maneira que é até hoje. Essa ideia legitima as relações de dominação e inaugura identidades sociais historicamente novas, como índios, negros e mestiços, além de trazer uma nova conotação para outras já existentes. A estas identidades se associaram hierarquias, lugares e papéis sociais. Após a conquista da América e devido ao controle dos metais preciosos levados desse continente, a Europa passou a ocupar a posição central na ampla rede de intercâmbio comercial que envolvia, além do que hoje se conhece como Europa, lugares como China, Índia, Oriente Médio, entre outros. Assim, ao passo em que a Europa se constitui através de sua nova identidade geocultural, passa também a exercer o controle do mercado mundial e a inserir todas as regiões e populações do planeta em seu sistema-mundo, o que faz com que se desencadeie um processo de re-identificação histórica, em que novas identidades geoculturais são imputadas a todas as outras regiões a partir da Europa. O modelo europeu passou a ser a medida para o desenvolvimento político, cultural e intelectual. Deste modo, a Europa passou também a controlar a subjetividade, a cultura, o conhecimento e a produção de conhecimento em nível global (QUIJANO, 2000).

A conquista da América Latina constituiu, portanto, a raiz do eurocentrismo que, conforme afirma o autor, foi elaborado de forma sistemática na Europa Ocidental em meados do século XVIII. A construção do eurocentrismo, ainda segundo Quijano (2000, p. 798, tradução nossa), aconteceu em associação à secularização burguesa do pensamento europeu e às "necessidades do padrão mundial de poder capitalista, colonial/ moderno, eurocentrado". Trata-se, como mostra o autor, de uma racionalidade específica ou uma perspectiva de conhecimento que, ao passo em que coloniza àquelas anteriores ou diferentes, ganha a hegemonia mundial. 
Ainda conforme afirma Quijano (2000), o eurocentrismo é constituído por uma série de elementos que atuam de maneira interdependente, e que são cultivados e desenvolvidos pela colonialidade do poder. Um deles é a classificação racial da população mundial. Essa classificação naturalizou "as diferenças culturais entre grupos humanos através de sua codificação com a ideia de raça" (QUIJANO, 2000, p. 802, tradução nossa). Assim, os diferentes povos nativos da América, maias, Guarani, entre muitos outros, cada um com sua própria cultura, história e identidade foram rotulados a partir de uma só identidade: "índios". O mesmo ocorreu com os povos da África, que se diversificavam em iorubas, bantos, entre muitos outros, e que passaram a ser conhecidos pelo rótulo único de "negros". Outro elemento é a articulação entre um dualismo e um evolucionismo linear e unidirecional, em que a humanidade segue uma trajetória que parte de um estado de natureza em direção à sociedade moderna europeia. Nessa perspectiva, o não-europeu não é somente diferente do europeu. Esse dualismo é ressignificado em um evolucionismo, onde o nãoeuropeu é relocalizado no tempo, passando a ser visto como anterior ao europeu. O mesmo é válido para as relações entre o pré-capital/ capital, primitivo/ civilizado, tradicional/ moderno, entre outras. Conforme explica Quijano (2000), nessa lógica, os índios e os negros eram raças inferiores porque estavam em um estágio de desenvolvimento anterior ao europeu, e sua cultura era inferior porque não havia ainda alcançado um grau de sofisticação civilizatória como a europeia.

Como assinala Mignolo (2017), a colonialidade é um conceito decolonial, uma vez que a decolonialidade é a desnaturalização, o questionamento e a desestabilização da colonialidade.

Dentro dos estudos decoloniais, a colonialidade do poder configura-se como categoria de referência. A partir deste conceito, foram propostos outros, entre os quais podem ser destacados a colonialidade do saber e a colonialidade do ser, devido ao seu caráter central dentro desse campo teórico e também por serem conceitos que se complementam. Na definição de Maldonado-Torres (2007), a colonialidade do saber é a reprodução de regimes de pensamento coloniais nos níveis epistemológicos e de produção do conhecimento e a colonialidade do ser se refere aos efeitos da colonialidade na experiência vivida.

A colonialidade do saber diz respeito ao formato eurocêntrico do conhecimento moderno. A experiência local europeia é universalizada como 
modelo de onde surgem os dispositivos de validação do conhecimento, sendo este controlado em associação à geopolítica global. Ligada a este conceito está a colonialidade do ser. Nela, o conceito de "raça" é utilizado para justificar o aniquilamento da humanidade do outro por meio da sua desqualificação epistêmica (ARIAS et al., 2012). Como sinaliza Maldonado-Torres (2007), com base em Dussel (1996), a formulação e a relevância do ego cogito se dá com base no ego conquiro, que implica para a afirmação cartesiana "Penso, logo existo" uma segunda dimensão, que compreende um outro - racializado - que não pensa, ou que não pensa da mesma maneira que eu - sujeito moderno -, logo, não existe, ou possui uma existência dispensável.

Mignolo (2017) declara que para o projeto colonial/ moderno foi elaborada uma retórica celebratória, sustentada pelo discurso da racionalidade, da cientificidade e do humanismo, surgido do Renascimento e do Iluminismo, que escondia uma dimensão oculta dos acontecimentos que ocorriam nas esferas da economia, inicialmente baseada na empresa colonial e depois moldada no capitalismo, e do conhecimento. O que se omitiu foi a "dispensabilidade (ou descartabilidade) da vida humana, e da vida em geral" (MIGNOLO, 2017, p. 4, grifos do autor).

Segundo Ribeiro (2018), o pensamento decolonial engendra um giro epistêmico, em que alguns elementos são ressignificados. O principal deles é a modernidade e a concepção vastamente aceita de que esta retirou a humanidade de um estado de imaturidade e a levou à razão. A autora afirma que é perceptível que as soluções modernas se mostraram incapazes de resolver muitos problemas modernos e, por isso, é necessário recuperar os saberes que foram silenciados e subalternizados.

O giro decolonial e a decolonização como projeto [...] se trata de pôr fim ao paradigma moderno da guerra, o que significa uma confrontação direta com as hierarquias de raça, gênero e sexualidade, que foram criadas ou fortalecidas pela modernidade europeia, no processo de conquista e escravização de um sem número de povos no planeta. (MALDONADO-TORRES, 2007, p. 161, tradução nossa).

Dussel (2000) propõe o conceito de Trans-Modernidade como projeto mundial de libertação. A modernidade, segundo o autor, possui um núcleo ad intra de racionalidade, que afirma que a humanidade evoluiu de um estado primitivo, mas, ao mesmo tempo, possui um lado ad extra, no qual aquela 
evolução justifica uma práxis irracional de violência para o domínio dos povos que ainda estariam no estágio anterior, supostamente pelo bem deles mesmos. Estes outros povos compõem, para Dussel (2000, p. 31), a “'outra-face' negada e vitimada da "Modernidade"”, sendo eles: “o mundo periférico colonial, o índio sacrificado, o negro escravizado, a mulher oprimida, a criança e a cultura popular alienadas, etc". A Trans-Modernidade, na concepção do autor, é composta pela negação do mito civilizatório, a revelação da contradição do ideal racional da modernidade e o reconhecimento da "outra-face" como vítima inocente da violência sacrificadora.

O pensamento decolonial pressupõe ainda o que Mignolo (2003 apud BALLESTRIN, 2013) chamou de "pensamento fronteiriço", um pensamento que não se alheia ao pensamento da modernidade, mas que, ao mesmo tempo, não se subjuga a ele. A via trans-moderna e fronteiriça coopera com o projeto de pluriversalidade, proposto por Mignolo como uma forma de decolonização epistemológica, que possui como algumas de suas estratégias "desprendimento, abertura, de-linking, desobediência, vigilância e suspeição epistêmicas" (BALLESTRIN, 2013, p. 108).

Para Walsh (2013), não há como "des-colonizar", porque não existe um estado nulo da colonialidade, não há como desfazer o que já foi feito. Porém, conforme afirma a autora, há como "de-colonizar", assumindo "posturas, posicionamentos, horizontes e projetos de resistir, transgredir, intervir, insurgir, criar e incidir" (p. 25, tradução nossa). O decolonial anuncia "um caminho de luta contínuo, no qual se pode identificar, visibilizar e conceber 'lugares' de exterioridade e construções alter-(n)ativas" (WALSH, 2013, p. 25, tradução nossa). Trata-se, de acordo com a autora, de movimentos não-lineares, que exigem práticas teóricas e pedagógicas de ação. Propondo um enlace entre o pedagógico e o decolonial, Walsh (2013, p. 31) nos convida a ver a pedagogia dentro das "lutas de conscientização, afirmação e desalienação" e da obstinação em fazer-se humano, diante da negação de sua humanidade.

A preferência de Walsh pelo uso do termo "decolonizar", ao invés de “descolonizar" se dá também como uma distinção entre o conceito histórico de descolonização e o projeto decolonial. O primeiro remete à libertação nacional como o ato de um país deixar de ser colônia de outro, enquanto o segundo se liga à ideia de resistir e insurgir contra um padrão de poder fundado na época do 
colonialismo, mas que se estende até a atualidade sob a forma de subalternização, invisibilização e silenciamento de determinados grupos humanos e suas culturas (BALLESTRIN, 2013).

Walsh (2004, apud RIBEIRO, 2018) elabora alguns critérios para que a descolonização epistêmica seja possível. Primeiramente, é preciso reconhecer que o conhecimento tem valor, cor, gênero e lugar de origem e, assim, interessa saber o lugar de onde se fala. Em segundo lugar, é necessário que os saberes ancestrais sejam recuperados. Em terceiro, é essencial que os conhecimentos deixem de ser entendidos como blocos compartimentados, que podem entrar em relação entre si, mas sim que se considerem conhecimentos e modos de pensar atravessando fronteiras, de forma a contribuir e intervir uns nos outros. Ribeiro (2018) conclui com base em Walsh que decolonizar é desvincular-se dos ideais eurocêntricos, o que não é o mesmo que trocar uma totalidade/ universalidade por outra, ocidental/ eurocêntrica por indígena/ afrocêntrica, mas sim estabelecer um diálogo em condição de igualdade, um diálogo intercultural.

Segundo Candau (2016), há certa polissemia entre os termos multiculturalismo e interculturalidade ${ }^{9}$. Entretanto, conforme aponta a autora, a interculturalidade advém da experiência da educação escolar indígena na América Latina e reflete uma perspectiva de caráter interativo do multiculturalismo.

De acordo com Walsh (2009), o termo "interculturalidade" é usado em três perspectivas diferentes: relacional, funcional e crítica. A perspectiva relacional corresponde ao modelo mais simples de contato e intercâmbio entre culturas. O ponto negativo desta perspectiva está no fato de ela esconder e diminuir o conflito e o contexto estrutural de colonialidade. A perspectiva funcional reconhece a diversidade e tenta inscrevê-la no interior da estrutura social vigente, mas não questiona a estrutura em si. Walsh diz que muitos autores se referem a esta

\footnotetext{
${ }^{9}$ Segundo Candau (2008, apud CANDAU, 2016), a interculturalidade está dentro do âmbito do multiculturalismo. De acordo com a autora, o multiculturalismo pode adotar uma das seguintes abordagens: o multiculturalismo assimilacionista, o multiculturalismo diferencialista ou monoculturalismo plural e o multiculturalismo interativo, que é a interculturalidade. A primeira abordagem caracteriza a sociedade como multicultural e concebe que as diferentes culturas são assimiladas em uma cultura hegemônica. A segunda abordagem considera que existem dentro de uma mesma sociedade diferentes grupos culturais que necessitam de contextos próprios para a manifestação de suas respectivas culturas e identidades culturais, mas sem interagir com os demais grupos. Já a última abordagem é considerada pela autora a mais apropriada para a criação de uma sociedade realmente democrática, uma vez que se baseia não só no respeito em relação à cultura do outro, mas também na interação entre diferentes culturas, em que uma pode aprender com a outra.
} 
perspectiva como a "nova lógica multicultural do capitalismo global". Por fim, há a interculturalidade crítica, cujo foco não é a questão da diversidade, mas do problema estrutural-colonial-racial. Walsh a caracteriza como algo que advém da demanda da subalternidade, não imposto de cima, e também não possui uma forma definida, mas é uma estratégia em incessante formulação. Segundo Walsh (2009), a interculturalidade caracteriza uma luta, na qual estão em constante disputa temas como identificação cultural, direito e diferença, autonomia e nação. Diz ainda a autora que um dos espaços centrais dessa luta é a educação, uma vez que este constitui o espaço onde valores, atitudes e identidades são formados e reproduzidos e onde o poder do Estado incide diretamente.

De acordo com Candau (2016, p. 81), a educação intercultural crítica vai além da promoção da simples tolerância com as diferenças, trazendo uma concepção de que "nas sociedades em que vivemos os processos de hibridização cultural são intensos e mobilizadores de identidades abertas, o que supõe que as culturas não são puras nem estáticas”. Segundo definição de 2013 criada pelo Grupo de Estudos sobre Cotidiano, Educação e Cultura (GECEC) da PUC-Rio,

A Educação Intercultural parte da afirmação da diferença como riqueza. Promove processos sistemáticos de diálogo entre diversos sujeitos - individuais e coletivos -, saberes e práticas na perspectiva da afirmação da justiça - socioeconômica, política, cognitiva e cultural -, assim como da construção de relações igualitárias entre grupos socioculturais e da democratização da sociedade, através de políticas que articulam direitos da igualdade e da diferença. (CANDAU, 2016, p. 83).

Afirmar a diferença como riqueza, ainda conforme diz a autora, implica em reconhecer que as culturas são incompletas e, ao interagirem, se enriquecem mutuamente (CANDAU, 2016) ${ }^{10}$.

Walsh (2009) afirma que a interculturalidade crítica é um projeto decolonial, porque além de não possuir funcionalidade no atual modelo de sociedade, o questiona e o desafia, propondo um modo "outro" de viver, que é necessariamente uma forma de com-vivência, no sentido de viver "com". Assim, a autora conceitua a interculturalidade crítica como a ferramenta pedagógica que contesta a racialização, subalternização e inferiorização e seus padrões de poder, ensejando modos outros de ser, viver e saber.

\footnotetext{
${ }^{10}$ A questão da incompletude das culturas é abordada por Candau (2016) em análise das ideias de Boaventura Sousa Santos.
} 
O pedagógico e a pedagogia são compreendidos por Walsh (2013, p. 29, tradução nossa), com base em Paulo Freire, como uma metodologia políticopedagógica mandatória às "lutas sociais, políticas, ontológicas e epistêmicas de libertação". Assim, a autora concebe as lutas sociais como espaços de "aprendizagem, desaprendizagem, reaprendizagem, reflexão e ação", cujas ações procuram perturbar a ordem do poder colonial. Diz Walsh que tais lutas sinalizam um problema, expressam sua oposição e organizam a intervenção, para que, então, se desfaça a circunstância encontrada e outra se torne possível.

$\mathrm{Na}$ concepção de Walsh, a pedagogia decolonial assume sua forma na interculturalidade crítica, partindo de uma prática política que contesta a geopolítica hegemônica monocultural e monorracional do conhecimento, capaz, assim, de abalar a colonialidade em suas estruturas sociais, políticas e epistêmicas. Nesse sentido, para Walsh, a pedagogia decolonial é uma práxis cujo fundamento é uma insurgência educativa propositiva, uma vez que ela não apenas denuncia as estruturas de opressão, mas também se volta à concepção de condições outras sociais, políticas, culturais e de pensamento, delineando-se enquanto uma perspectiva pedagógica que entende a pedagogia como política cultural. Também segundo Walsh, trata-se de uma operação teórica e prática ainda sendo gestada nos sistemas escolares e em outros espaços educativos (OLIVEIRA \& CANDAU, 2010).

Ribeiro (2018) atenta para o fato de que, ao longo das décadas de 1980 e 1990, muitos países latino-americanos tiveram reformas educativas voltadas ao multiculturalismo de caráter neoliberal. Estas reformas poderiam ter sido estimuladas por reivindicações sociais, mas, na realidade, elas buscavam ajustar a educação aos moldes da modernização e do desenvolvimento. Conforme discute Walsh (2009, apud RIBEIRO, 2018), tais reformas reforçaram o discurso da diversidade e da interculturalidade como tolerância com a diferença cultural, sem mudanças significativas.

Candau (2013) e Walsh (2009) abraçam a ideia de uma interculturalidade crítica, que emana de diferentes esferas da sociedade, como um projeto que se origina da reivindicação da subalternidade pelo direito aos lugares e a ter voz. Conforme argumenta Ribeiro (2018), o conhecimento ocupa um espaço de grande importância nesse projeto, porque questiona a legitimidade atribuída pelo eurocentrismo a um tipo único de conhecimento e de ser. 
A interculturalidade não é meramente uma outra forma de se referir ao simples contato entre o ocidente e outras civilizações, mas sim um elemento dentro de "uma configuração conceitual que propõe um giro epistêmico capaz de produzir novos conhecimentos e outra compreensão simbólica do mundo, sem perder de vista a colonialidade do poder, do saber e do ser" (OLIVEIRA \& CANDAU, 2010, p. 27). Além disso, essa perspectiva, segundo Walsh (2009), não representa simplesmente introduzir novos temas nos currículos ou nas metodologias pedagógicas, mas sim uma transformação estrutural e sóciohistórica. Nesse sentido, a autora critica o fato dos termos interculturalidade e multiculturalismo terem sido usados em muitas políticas públicas educacionais na América Latina como meio de apenas agregar as reivindicações dos subalternizados pelo ocidente ao aparato estatal, onde o que perdura ainda é a hegemonia do padrão epistemológico eurocêntrico e colonial.

Walsh (2016) propõe ainda o conceito de brechas decoloniais. Segundo a autora, não existe um caminho a seguir que nos leve do colonial ao decolonial. O caminho precisa ser feito abrindo-se espaços nas brechas da própria colonialidade. Portanto, para a autora, o decolonial é algo a ser vivido. Diz ainda Walsh que tais brechas estão por toda parte, mas são difíceis de ser notadas devido a dois elementos principais: a atual forma míope de viver e a incapacidade de uma parcela da sociedade, em especial da esquerda, de se reinventar e imaginar outros cenários possíveis. De acordo com Walsh (2016, p. 72), "as brechas se transformam no lugar e no espaço a partir do qual a ação, militância, resistência, insurgência e transgressão são impulsionadas, onde as alianças se constroem, e surge um modo-outro que se inventa, cria e constrói”.

\section{3}

\section{A decolonialidade e o museu}

De acordo com Cocotle (2019), a imagem do museu é hoje a de uma instituição fossilizada, cujas existência e permanência precisam ser justificadas. Para a autora, o caminho para isso é descolonizá-lo. Diz ela que uma vez que o museu é fruto e mecanismo de uma narrativa colonial, é cada vez mais considerado necessário que se instaurem práticas descolonizadoras no plano das políticas de exibição e de coleção. Além disso, salienta que, ainda que essa perspectiva remeta aos anos 1970, com o surgimento da Nova Museologia e, 
como desdobramento dela, da museologia crítica, somente recentemente os museus, por meio de uma demanda da arte contemporânea, vêm denunciando de fato sua narrativa colonial e buscando alternativas. No entanto, o processo não é simples, visto que esta instituição nasce dentro da modernidade e encontra na lógica colonial seu princípio epistêmico e seu propósito de existir. Trata-se de uma instituição ligada à narrativa do Estado-nação, aos processos de patrimonialização e à questão da memória a eles vinculada, funcionando como um mecanismo de visibilidade dentro da estrutura de poder.

A autora faz um exame de alguns pressupostos que permearam as tentativas de descolonizar o museu, tentando encontrar seus pontos fracos para que esse projeto ainda não tenha vingado. Assim, aponta duas tendências: iniciativas que se interessam pelas políticas de identidade e representatividade e ações voltadas à introdução do Sul enquanto uma categoria epistemológica.

Cocotle afirma que a primeira tendência surge a partir do debate em torno do multiculturalismo e da hibridização cultural, que, por sua vez, ocorre de forma simultânea à crise do Estado-nação e ao declínio do modelo tradicional de fronteira. Nesse sentido, começam a ser foco de questionamento as categorias de "identidade", "representação" e "apropriação", em um debate que se divide em três linhas: "1. A narrativa dos museus nacionais e sua relação com o discurso histórico, a memória e a identidade coletiva; 2 . A representatividade cultural de minorias e grupos ditos subalternos; 3. A conformação, propriedade e gestão das coleções" (COCOTLE, 2019, p. 5).

Em sua análise, a autora observa que a crítica à lógica colonial no museu passou a girar em torno do reconhecimento da diversidade cultural e das políticas de representatividade. No entanto, em sua concepção, a "multiculturalidade" entrou no museu de maneira temática, não chegando à estrutura. As tentativas de inclusão de uma narrativa mais plural foram configuradas enquanto uma fala sobre o "outro", mas aqueles que tinham voz permaneciam os mesmos. Conforme busca mostrar a autora, os novos projetos configuraram-se como investidas despolitizadas de elogio à diversidade, que escapavam do debate dos conflitos e tensões históricas, se constituindo enquanto um discurso "igualador da diferença".

Dada a centralidade que a ideia de raça recebe na perspectiva decolonial, seus conceitos podem ser apropriados para considerar a presença ou ausência da memória e de como são moldados os regimes de representação de grupos 
historicamente subalternizados nos espaços museais. Cunha (2006, apud GIL \& MEINERZ, 2017), que analisou exposições de nove museus brasileiros, afirma que o discurso museal sobre as populações africanas e afro-brasileiras ainda é preso na experiência do passado e no retrato dessas populações como vítimas, não contemplando a história dos movimentos de reação e de resistência. Segundo o autor, africanos e afro-brasileiros não só raramente constituem os temas das exposições, como, na maioria das vezes, aparecem como coadjuvantes da história branca. Além disso, a cultura africana aparece normalmente no discurso expográfico influenciando a brasileira, mas não como uma de suas bases. Faltam ainda nos museus, de acordo com o autor, referências contemporâneas do continente africano. Quanto à questão da luta e da resistência no passado de opressão que estas populações viveram, o autor ressalta que as resistências cotidianas, as experiências comunitárias, as revoltas e o movimento quilombola são experiências invisibilizadas no museu. Essas histórias de resistência, nos raros casos em que são contadas, surgem na perspectiva de um personagem individual, fato que reforça a representação da insubordinação. Além disso, ainda segundo Cunha (2006, apud GIL \& MEINERZ, 2017), os museus comumente trazem representações das populações negras através de arquétipos anônimos, como, por exemplo, o capoeira ou a baiana do acarajé, não por personagens com uma história de vida individualizada.

Apesar de a Nova Museologia buscar uma narrativa mais plural e de valorização de diferentes etnias, a colonialidade ainda parece operar no espaço museal. Um exemplo deste fato pode ser visto na pesquisa de Silva (2016), na qual é analisada a figura da mulher negra no discurso expográfico de museus na cidade de Salvador, no estado da Bahia. Tal pesquisa mostra que essa personagem constantemente assume papel secundário. Segundo a autora, a representação mais comum da mulher negra no museu é aquela como Mãe Preta (a ama-de-leite), como escravizada ou simplesmente como elemento da economia do período colonial.

Quanto aos povos originários das Américas, segundo Anjos (2016), a presença indígena no Brasil e o que ela expressa atualmente para quem vive no país é um tema ignorado e suprimido na arte brasileira contemporânea. Para o autor, trata-se de uma omissão que é tanto um reflexo do lugar concreto e simbólico reservado para estes povos quanto uma consequência do processo de 
colonização do país. Anjos (2016) afirma também que repetidamente artefatos indígenas são incluídos em exposições de artes visuais, como uma forma de conectar duas áreas de criação física e simbólica. Entretanto, a singularidade dessa arte sofre um esvaziamento e sua leitura é realizada através de um olhar arrogante de superioridade, ainda que afetuoso. $\mathrm{O}$ autor assinala ainda que a questão indígena, quando contemplada nas exposições, tem suas marcas de conflito negligenciadas.

Muñiz-Reed (2019) investiga curadores e instituições de arte dentro da matriz colonial e a possibilidade de uma prática curatorial decolonial. Segundo o autor, na teoria da arte, Walter Mignolo, semiólogo argentino e um dos principais autores dentro da perspectiva decolonial, foi quem deu início ao debate sobre uma estesia/ estética decolonial.

Segundo Mignolo (2010), o conceito de estética advém da palavra aesthesis, no grego antigo. No entanto, o significado de aesthesis se referia ao processo de percepção, envolvendo as sensações visuais, gustativas, auditivas e de outros sentidos. Diz o autor que, ao longo do século XVII, esse conceito passou por uma reelaboração diretamente influenciada pelas ideias de Immanuel Kant, se restringindo à "sensação do belo". Para Mignolo (2010), esta transformação do conceito constituiu a colonização da aesthesis pela estética. Ocorreu nesse processo a universalização de uma experiência estética europeia, que definia a partir de si o que era o belo, e, ao mesmo tempo, a desvalorização de toda experiência estética diferente. Mignolo propõe então que decolonizemos a estesia, através do contraconceito de estesia decolonial. Para Muñiz-Reed (2019, p. 6), a crítica de Mignolo ao conceito kantiano de estética pode ser aplicada aos curadores e instituições de arte, que receberam o papel de "guardiões do belo e do sublime", o que levou ao estabelecimento de um cânone e ao silenciamento de histórias.

A fim de investigar configurações de práxis artísticas de teor decolonial, Mignolo (2010) faz um relato de três exposições museográficas ocorridas entre os anos de 1992 e 2008. Para o autor, a tarefa de um projeto decolonial consiste em desmascarar a modernidade, revelando sua outra face, a colonialidade, para que, a partir de então, seja possível a construção de futuros nos quais a modernidade/ colonialidade constituirá apenas um capítulo infeliz na história da humanidade. 
As duas primeiras exposições das quais Mignolo (2010) faz o relato são ambas de Fred Wilson ${ }^{11}$ e realizadas em 1992, época em que se celebrava os 500 anos de "descobrimento" da América. A primeira, ocorrida no Museu Histórico de Baltimore (Maryland Historical Society), se chama Mining the Museum ${ }^{12}$. Wilson organizou a instalação com peças arquivadas no depósito do museu, dispondo-as de forma que possibilitasse o surgimento de novas interpretações. A segunda exposição, Site Unseen: Dwellings of the Demon ${ }^{13}$, ocorreu no Museu da Cultura Mundial, em Gotemburgo, na Suécia. Na ocasião, a diretora do museu, Jette Sandahl, afirmou que pediu ao artista que trouxesse os demônios do museu à superfície, um exercício bem similar ao que Wilson já havia realizado na exposição anterior. Conforme relata Mignolo (2010), em Mining the Museum os demônios trazidos do depósito se referiam à história da escravidão nos Estados Unidos e, em Site Unseen, os demônios diziam respeito à trajetória do próprio Museu de Gotemburgo e de sua histórica usurpação de objetos das civilizações indígenas.

Embora alguns caracterizem a obra de Wilson como pós-moderna, para Mignolo (2010), ela é decolonial, porque é constituída por ações de desobediência estética e institucional. Segundo Mignolo (2010, p. 18, tradução nossa), “a estética é abertamente política e decolonizadora, como é também a inversão do papel que o museu interpreta na esfera pública e na educação".

A terceira exposição relatada por Mignolo (2010) é do Museu Nasher, na Universidade de Duke, na Carolina do Norte, Estados Unidos. Trata-se da exposição de Pedro Lasch $^{14}$, nomeada Black Mirror ${ }^{15}$. Se Wilson trata de uma experiência vivida pelos afro-americanos, Lasch se volta aos latino-americanos. $\mathrm{Na}$ exposição, Lasch colocou estátuas de civilizações pré-colombianas viradas para um espelho negro, no qual não se viam, como seria esperado, o reflexo das

\footnotetext{
${ }^{11}$ Fred Wilson é um artista, nascido nos Estados Unidos e auto-descrito como "descendente de africanos, nativo-americanos, europeus e ameríndios". A marca de sua obra está em dispor objetos de maneira que evoquem interpretações incomuns, geralmente críticas e problematizadoras da questão racial e do privilégio.

${ }^{12}$ A tradução em português, respeitando o significado que a exposição buscou empreender, ficaria algo como Garimpando o Museu ou Escavando o Museu.

${ }^{13}$ Em português: Lugar Invisível: Moradias do Demônio.

${ }^{14}$ Pedro Lasch é um artista nascido no México. Ele se dedica à arte colaborativa e com viés pedagógico. Sua obra é voltada principalmente à discussão sobre a situação dos imigrantes e dos grupos indígenas.

${ }^{15}$ Em português: Espelho Negro.
} 
estátuas, mas sim imagens de obras europeias, com representação de pessoas brancas. Na interpretação de Mignolo, a obra evidencia o fato de que não conseguimos ver a beleza e a criatividade das civilizações destroçadas e conseguimos ver apenas uma civilização. No entanto, outra interpretação possível seria a de que, na América Latina, somos naturalizados a nos enxergarmos pela imagem do outro, do colonizador.

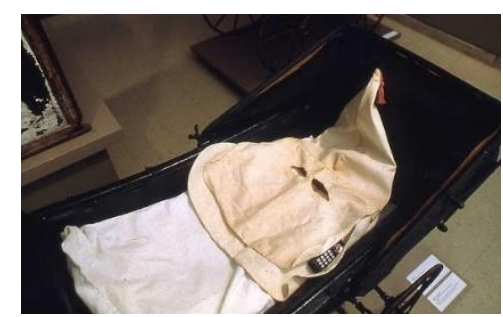

Figura 3: Detalhe de Mining the Museum

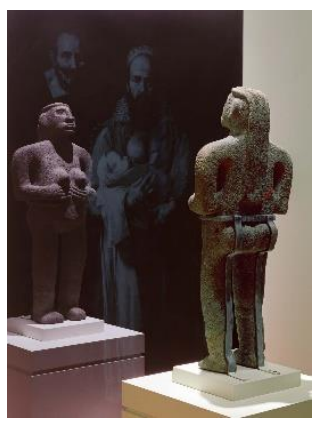

Figura 4: Detalhe de Black Mirror

Muñiz-Reed (2019) destaca o fato de que os curadores, ao contrário dos artistas, são aqueles que estão do lado de dentro da estrutura. Por isso, aos artistas é mais fácil criticar as instituições e exercer uma práxis artística decolonial. Para o autor, as exposições que Mignolo traz como exemplos refletem uma interessante aproximação do trabalho de artista e de curador, uma vez que tanto Lasch quanto Wilson são artistas que começaram a focar seu trabalho não na criação, mas na seleção e organização de objetos de coleções preexistentes. Nesse esforço, os artistas buscam sugerir novas leituras e denunciar a suposta neutralidade das obras, reenquadrando ou recontextualizando os objetos, forjando um instrumento decolonial em curadoria.

Cocotle (2019) também destaca Mignolo como o principal autor entre os que propõem a decolonialidade a incidir na arte contemporânea a partir do que concebe como a "estética decolonial". O próprio, segundo a autora, assumiu junto com Pedro Pablo Gómez ${ }^{16}$ a curadoria da mostra Estéticas Decoloniales, de 2010. Sua proposta era abalar a lógica colonial determinada pelo "privilégio do olho", ou seja, desafiar categorias estéticas já legitimadas.

\footnotetext{
${ }^{16}$ Pedro Pablo Gómez é artista e estudioso da arte e da cultura em uma perspectiva decolonial, da Colômbia.
} 
A prática curatorial decolonial, conforme conceituada por Muñiz-Reed (2019), é aquela que defende uma desobediência epistêmica, sustentada em uma lógica outra. $\mathrm{O}$ autor traz como exemplo de curadoria decolonial a exposição Magiciens de La Terre de Jean-Hubert Martín ${ }^{17}$, de 1989. Para o autor, essa exposição pode ser caracterizada como decolonial porque contemplou cenas artísticas desenvolvidas além do Ocidente, ademais de uma variedade de histórias e cosmologias indígenas e desafiou a noção de parâmetros artísticos globalizados, ressaltando a pluriversalidade de estesia.

No entanto, o autor destaca que não basta a integração sistemática de histórias antes invisibilizadas para que um projeto curatorial seja caracterizado como decolonial. Pelo contrário, a inclusão dessas histórias no museu sem um cuidado adequado pode sustentar visões estereotipadas ou folclóricas.

Ainda que seu interesse tenha como foco a curadoria, Muñiz-Reed (2019, p. 11) sinaliza o fato de ela constituir somente uma esfera de um projeto decolonial maior, uma "convocatória cultural à luta" para a concepção do "mundo de outra maneira" 18 .

Para Cocotle (2019), embora as políticas de exibições e programas públicos de muitos museus tenham buscado assumir uma identidade contra-hegemônica e contestadora, tais museus, de maneira geral, entram em contradição quando são consideradas as suas políticas de gestão e organização institucional. Segundo a autora, no projeto de contestação da colonialidade, o "Sul" surge como categoria, em uma referência tanto a regiões que se localizam geograficamente ao sul como a populações que guardam uma herança colonial comum, que se aproximam por seus padrões de colonização, de migração e por sua mistura cultural. Um dos aspectos mais contraditórios, conforme salienta Cocotle $(2019$, p. 9) é a "projeção

\footnotetext{
17 Magiciens de La Terre (Mágicos da Terra) foi uma exposição de arte contemporânea que aconteceu no Centro Georges Pompidou e no Grande halle de la Villete, na França. A mostra deu visibilidade a artistas de diversas partes do mundo, saindo do eixo Europa-Estados Unidos, além de trazer temáticas questionadoras das estruturas coloniais/ modernas. Jean-Hubert Martín é um historiador de arte e curador, nascido na França, que trouxe para espaços de legitimação artistas contemporâneos de vanguarda.

18 Esta é uma referência indireta ao trabalho de Arturo Escobar, intitulado "Mundos e conhecimentos de outro modo", apresentado no Terceiro Congresso Internacional de Latinoamericanistas, em Amsterdã, em 2002. Segundo Oliveira \& Candau (2010), este trabalho constituiu a primeira referência direta ao grupo Modernidade/Colonialidade (M/C), cujos principais representantes são Dussel, Quijano, Mignolo, Grossfoguel, Walsh, Maldonado-Torres e o próprio Escobar. Trata-se de um grupo de estudiosos de diversas áreas do conhecimento que se dedica à crítica do projeto moderno e colonial e à elaboração de alternativas para ele.
} 
desse "Sul" nos, e a partir dos, modelos de gestão institucional do museuempresa, [...] modelo museal ligado ao circuito internacional do mercado da arte contemporânea". Para a autora, o "museu do Sul" parece buscar ser reconhecido como um "museu do primeiro mundo", isto é, "empresarial, eficiente, sucesso de bilheteria e de vendas", um museu que conseguiu se descolonizar em seu discurso curatorial e museográfico, mas que se recolonizou institucionalmente.

Abordando especificamente a arte e o pensamento negros e anticoloniais, Mombaça (2020) analisa que vem emergindo uma tendência de mercado global dentro dos sistemas de arte e produção de conhecimento que "valorizam" tais produções, mas que constitui, na verdade, uma comodificação dessas perspectivas ${ }^{19}$. Para a autora, trata-se de uma maneira de tirar a potência e o significado do verbo "descolonizar".

Além das questões artísticas, curatoriais e administrativas do museu, é importante assinalar que a colonialidade está entranhada nas instituições e na vida de modo geral de forma tão forte que, em muitos aspectos, ela passa despercebida. Lilia Schwarcz, em entrevista a Carneiro \& Mesquita (2019), comenta que a colonialidade e o pensamento único são impostos de tal maneira no museu que até a maneira de referenciar as obras é ocidental, gerando certa dificuldade quando diante de uma obra cuja autoria é coletiva. Diz ela que, em alguns casos, as obras são referenciadas com legendas de "artista desconhecido", quando, na verdade, são criações de povos que não adotam a ideia de autoria individual.

\footnotetext{
${ }^{19}$ Bell Hooks (2019) faz uma observação similar, a partir da análise da inclusão de elementos da cultura negra no cinema, na música e na cultura pop de maneira geral. Afirma ela que "atualmente, a comodificação da diferença promove paradigmas de consumo nos quais qualquer diferença em que o Outro habite será erradicada por meio da troca, pelo consumo canibal que não apenas desloca o Outro, mas nega a importância da história do Outro através de um processo de descontextualização" (HOOKS, 2019, p. 81).
} 


\section{3 \\ Cartograma ${ }^{20}$}

Como mencionado na introdução, a pesquisa foi realizada em uma abordagem qualitativa de caráter descritivo e exploratório. A pesquisa qualitativa, como afirmam Ferreira et al. (2002), trabalha com uma diversificação de métodos, buscando o estudo minucioso de pequenas amostras. Embora esse tipo de abordagem, por seu caráter menos objetivista, envolva o risco de impregnar-se de subjetividade, ele se mostra o mais adequado para a presente investigação. A caracterização desta pesquisa como descritiva também parece a mais adequada uma vez que, como conceituados por Gil (2002), os estudos descritivos buscam a descrição das características de uma população ou fenômeno em relação às suas variáveis. Quanto aos estudos exploratórios, o autor destaca seu uso relativo a propiciar uma aproximação do problema, tornando-o mais explícito.

Oliveira (2008, p. 41) conceitua a pesquisa qualitativa como "um processo de reflexão e análise da realidade através da utilização de métodos e técnicas para compreensão detalhada do objeto de estudo em seu contexto histórico e/ ou segundo sua estruturação". Para a autora, não é incompatível com a abordagem qualitativa o uso de alguns dados quantitativos.

Adotar a prática de combinar técnicas de análise quantitativa com técnicas de análise qualitativa proporciona maior nível de credibilidade e validade aos resultados da pesquisa evitando-se, assim, o reducionismo por uma só opção de análise. (OLIVEIRA, 2008, p. 43, grifo da autora).

Assim, conforme será observado, embora a presente pesquisa seja de caráter qualitativo, alguns dados apresentados são quantitativos. Alguns dados estão tanto contabilizados como também organizados em tabelas, como é o caso das respostas do Museu de Arte do Rio (MAR) aos questionários do Grupo de Estudo e Pesquisa em Educação, Museu, Cultura e Infância (GEPEMCI).

Em relação ao delineamento da pesquisa, foi selecionado como procedimento para a coleta de dados a análise bibliográfica e documental do material produzido sobre e pelo museu investigado.

\footnotetext{
${ }^{20}$ Cartograma "é um esquema representativo de uma superfície ou parte dela, sobre a qual são apresentadas informações quantitativas e qualitativas, de eventos geográficos, cartográficos e socioeconômicos" (OLIVEIRA, 1993). O termo aqui é utilizado metaforicamente em uma referência ao esquema metodológico da pesquisa.
} 
Oliveira (2008) conceitua a pesquisa bibliográfica como o gênero de estudos e análises de documentos que fazem parte do domínio público e científico, como materiais bibliográficos, dissertações, teses, entre outros. Tais fontes de informação são também comumente chamadas de fontes secundárias. Já a pesquisa documental é caracterizada pela autora como uma investigação em documentos que ainda não passaram por um tratamento científico, como reportagens, filmes, fotografias, entre outros. Tais documentos são também denominados fontes primárias.

Em relação à pesquisa documental, Sá-Silva et al. (2009) a conceituam como um método de investigação de documentos dos mais diversos tipos. É destacada pelos autores a dificuldade em formular uma definição de documento. Dizem eles que, durante muito tempo, em especial por influência do positivismo, foi considerado documento somente o material escrito. No entanto, esse conceito foi ampliado com a Escola de Annales ${ }^{21}$, passando a serem considerados documentos materiais cinematográficos, fotográficos, gravações de entrevistas, entre outros tipos de suporte que registre algum tipo de informação, deixando-a disponível para consulta posterior. Conforme menciona Gil (2002, p. 46),

\begin{abstract}
Nem sempre fica clara a distinção entre a pesquisa bibliográfica e a documental, já que, a rigor, as fontes bibliográficas nada mais são do que documentos impressos para determinado público. Além do mais, boa parte das fontes usualmente consultadas nas pesquisas documentais, tais como jornais, boletins e folhetos, pode ser tratada como fontes bibliográficas. Nesse sentido, é possível até mesmo tratar a pesquisa bibliográfica como um tipo de pesquisa documental, que se vale especialmente de material impresso fundamentalmente para fins de leitura.
\end{abstract}

Devido ao seu grau de similaridade, a pesquisa bibliográfica e a documental aparecem aqui dentro de um mesmo bloco. A utilização dos dois procedimentos teve como intenção obter uma visão mais ampla do objeto através do acesso a documentos sem discriminar os que passaram ou não por um tratamento analítico prévio. Como será explicitado no item 3.2, compuseram o corpus da pesquisa desde teses e dissertações escritas sobre o MAR até vídeos disponíveis no canal do YouTube da própria instituição. Em seguida, para o tratamento dos dados, optou-se pelo uso da análise de conteúdo.

\footnotetext{
${ }^{21}$ A Escola de Annales é como ficou conhecida a corrente historiográfica que surgiu na França, no início do século XX, e que trouxe uma renovação para as pesquisas históricas, o enriquecimento da perspectiva sobre os fatos através do tratamento multidisciplinar, envolvendo as ciências sociais de maneira geral (BURKE, 1991).
} 
A análise de conteúdo é um método empírico, composto por uma série de instrumentos metodológicos em aprimoramento contínuo, empregado em diversos tipos de discursos, a fim de desvendá-los criticamente. Trata-se de um exame em profundidade de um material discursivo a partir do que o seu sistema linguístico oferece. A finalidade é descobrir os encadeamentos entre o conteúdo do discurso e as questões exteriores (BARDIN, 2009).

Com a análise, pode-se buscar investigar a presença ou a ausência de determinados elementos, a frequência com que aparecem, a intensidade medida através dos elementos linguísticos, a co-ocorrência de certos elementos, a orientação partidária, contrária ou isenta. A organização da análise se dá em três etapas: (1) a pré-análise, também chamada de análise flutuante; (2) a exploração do material, constituída pela codificação e classificação; (3) o tratamento dos resultados, em que se infere sobre os dados tratados e, por fim, se interpreta os mesmos. Na interpretação dos dados, as análises são embasadas com a retomada do referencial teórico (BARDIN, 2009).

A pesquisa foi dividida em três etapas. A primeira etapa, que será discutida no item seguinte, foi a etapa de elaboração do projeto, na qual foi feito um levantamento bibliográfico inicial. A segunda etapa constituiu a coleta de dados e a produção de relatórios. A terceira etapa foi a de interpretação dos dados, que gerou os textos de discussão apresentados no capítulo 4.

\section{1 \\ Primeira etapa: Levantamento bibliográfico inicial}

Em um momento preliminar da pesquisa, foi feito um levantamento bibliográfico para obter um panorama das pesquisas que relacionavam a decolonialidade e o museu. Para este levantamento, foram utilizados os descritores decolonialidadel decolonial/ descolonialidadel descolonial + museu. Foi também realizado um segundo levantamento, empregando o descritor Museu de Arte do Rio, para compreender o que já foi pesquisado especificamente sobre este museu. Para a busca, as seguintes bases foram utilizadas: o portal de periódicos da Coordenação de Aperfeiçoamento de Pessoal de Nível Superior (CAPES), o catálogo de Teses e Dissertações da CAPES, a Biblioteca Digital Brasileira de Teses e Dissertações (BDTD), a base da Scientific Electronic Library Online (SciELO) e o Google Acadêmico. Com o intuito de restringir o 
número de resultados, foram utilizados os operadores booleanos AND e NOT, eliminando resultados que, por exemplo, no segundo levantamento, indicavam trabalhos sobre o Rio Grande do Sul ou sobre Museu de Arte Moderna ou Contemporânea. Além disso, o levantamento inicial foi restrito a trabalhos realizados no período de 2015 a 2019.

Quanto à relação decolonialidade/museu, no portal de periódicos da CAPES, foram encontrados 15 resultados; no catálogo de teses e dissertações da CAPES, 3 resultados; na base SciELO, foi encontrado somente um resultado; no Google Acadêmico, foram encontrados 1.300 resultados sem incluir patentes ou citações. Restringindo os resultados do Google Acadêmico somente para português, foram obtidos 1.080 resultados, dos quais foram selecionados os 30 primeiros resultados que o site colocou como mais relevantes para a pesquisa. Foi então feita uma primeira seleção dos textos a partir dos títulos e, posteriormente, uma segunda seleção a partir da leitura dos resumos.

Entre os temas que apareceram de modo mais recorrente, destacam-se:

- Relações étnico-raciais e racismo;

- Na área de artes: trajetórias biográficas e artísticas de artistas específicos da América Latina, relatos de projetos artísticos e expressões artísticas;

- Direito jurídico;

- História da Arte da América Latina;

- Infância;

- Arqueologia e escravidão;

- Um museu específico;

- Educação museal;

- A constituição dos museus de maneira geral;

- Patrimônio de culturas indígenas e afro-diaspóricas;

- Visibilidade ou invisibilidade de identidades historicamente subalternizadas nos museus.

Os trabalhos que dialogam com a investigação intencionada pela pesquisa aqui apresentada foram selecionados e organizados no quadro a seguir: 
Quadro 1. Levantamento bibliográfico inicial: Museu + Decolonialidade

\begin{tabular}{|c|c|c|c|c|}
\hline Autor & Ano & Título & $\begin{array}{ll}\text { Objeto } & \text { de } \\
\text { investigação } & \end{array}$ & Temas abordados \\
\hline Amaral & 2015 & $\begin{array}{l}\text { Da colonialidade do } \\
\text { patrimônio ao } \\
\text { patrimônio decolonial }\end{array}$ & $\begin{array}{l}\text { Processo } \quad \text { de } \\
\text { patrimonialização do } \\
\text { modo de fazer viola } \\
\text { de cocho }\end{array}$ & $\begin{array}{l}\text { • Processos } \\
\text { patrimonialização } \\
\text { • Potencial } \\
\text { decolonizador } \\
\text { patrimonialização } \\
\end{array}$ \\
\hline $\begin{array}{l}\text { Gil \& } \\
\text { Meinerz }\end{array}$ & 2017 & $\begin{array}{l}\text { Educação, patrimônio } \\
\text { cultural e relações } \\
\text { étnico-raciais: } \\
\text { possibilidades para a } \\
\text { decolonização } \\
\text { saberes }\end{array}$ & $\begin{array}{lr}\text { Projeto } & \text { Territórios } \\
\text { Negros: } & \text { Afro- } \\
\text { Brasileiros } & \text { em Porto } \\
\text { Alegre } & \end{array}$ & $\begin{array}{ll}- & \text { Relações étnico- } \\
\text { raciais } & \\
- & \text { Direito ao território }\end{array}$ \\
\hline $\begin{array}{l}\text { Miranda } \\
\text { \& Araújo }\end{array}$ & 2019 & $\begin{array}{l}\text { Memórias contra- } \\
\text { hegemônicas } \\
\text { educação para as } \\
\text { relações étnico-raciais: } \\
\text { práticas decoloniais } \\
\text { em periféricos contextos } \\
\text { perifos }\end{array}$ & $\begin{array}{l}\text { Museu da Maré e } \\
\text { Fundo Documental } \\
\text { Afro-Andino }\end{array}$ & $\begin{array}{l}\text { - Relações étnico- } \\
\text { raciais } \\
\text { - Lugares } \\
\text { memória }\end{array}$ \\
\hline Pereira & 2018 & $\begin{array}{l}\text { Museologia } \\
\text { Decolonial: Os Pontos } \\
\text { de Memória e a } \\
\text { insurgência do fazer } \\
\text { museal }\end{array}$ & $\begin{array}{l}\text { Programa Pontos de } \\
\text { Memória }\end{array}$ & $\begin{array}{l}\text { - } \quad \text { Compromisso } \\
\text { social do museu } \\
\text { - } \quad \text { Participação } \\
\text { popular no museu }\end{array}$ \\
\hline Estelita & 2019 & $\begin{array}{l}\text { O contexto epistêmico } \\
\text { do museu e da história } \\
\text { da arte a partir de uma } \\
\text { abordagem decolonial }\end{array}$ & $\begin{array}{l}\text { Museu e história da } \\
\text { arte }\end{array}$ & $\begin{array}{l}\text { - } \quad \text { Espaços } \\
\text { legitimação de saberes } \\
\text { - } \quad \text { Epistemicídio }\end{array}$ \\
\hline
\end{tabular}

(Elaborado pela autora)

Estelita (2019) elabora uma reflexão a partir de autores não eurocêntricos, se debruçando sobre o museu e a história da arte como contextos de narrativas de legitimação de saberes, problematizando a sua suposta neutralidade. Primeiramente, a autora se volta à questão dos objetos guardados e preservados para contar uma história. Em seguida, aborda as sociedades que não "fazem história" da mesma maneira, isto é, não preservam suas memórias em museus ou livros, mas sim dentro da tradição oral. Dessa maneira, aponta o surgimento de um padrão de produção de conhecimento que se impõe como verdadeiro e universal, desqualificando outras formas de saber e de guardar memórias, configurando um processo conhecido dentro dos estudos pós-coloniais e decoloniais como epistemicídio. A autora então busca pensar saídas para estas políticas de dominação epistêmicas. No entanto, afirma que não é possível empreender esse projeto saindo do modelo já estabelecido. Procura, portanto, diferenciar os diversos campos teóricos que surgiram a partir de questionamentos similares, como aqueles que abordaram o colonialismo de uma perspectiva descolonial, pós-colonial, decolonial, entre outros. A autora busca mostrar em que sentidos os teóricos dessas diferentes vertentes divergem e convergem, destacando 
alguns dos conceitos que dialogam melhor com seus questionamentos a respeito do museu e da questão da universalidade. Sua conclusão é a de que é preciso que se leve em conta a não neutralidade do sujeito epistêmico.

Pereira (2018) efetua uma investigação sobre o Programa Pontos de Memória, concebido como um ato insurgente e decolonizador dentro da prática museal. Esse programa foi lançado em 2008, na cidade do Rio de Janeiro, e visa estimular a criação e participação popular no fazer museal na cidade. Embora a metodologia de pesquisa seja focada na análise de documentos sobre o programa, como material de pesquisa a pesquisadora também se valeu de revisão bibliográfica e coleta de depoimentos e entrevistas.

Destaca as ideias de autoras da Museologia Social a respeito do compromisso social do museu, em especial em relação à salvaguarda de memórias e de culturas de populações historicamente subalternizadas e que foram invisibilizadas no discurso museal tradicional. Identifica a perspectiva destas autoras com o que posteriormente seria compreendido como decolonial.

Pereira (2018, p. 70) contextualiza os esforços dentro da museologia de inserir o museu dentro de um contexto de "possibilidades conscientizadoras, educadoras, problematizadoras e participativas", que criam musealidades transgressoras. Nesse sentido, aponta a Nova Museologia como inspiradora para o surgimento da Museologia Social, que pensa o fazer museal na "relação dialética e epistemológica da sociedade nos museus e destes em sociedade", baseado na subversão da "lógica da colonialidade do poder, saber e ser no âmbito dos processos museais" (PEREIRA, 2018, p. 84).

A autora traça o percurso das políticas públicas de cultura no Brasil e destaca três tradições em relação às mesmas: ausências, autoritarismos e instabilidades. Enfatiza a gestão de Gilberto Gil $^{22}$ no Ministério da Cultura como um momento de efervescência na reformulação do fazer museal, tendo como um de seus marcos o surgimento do Museu da Maré.

A autora conclui que os Pontos de Memória são processos museais decolonizadores e insurgentes, constituindo necessariamente práticas pedagógicas - no sentido amplo de pedagogia, como atribuído por Catherine Walsh. Nessa

\footnotetext{
${ }^{22}$ Gilberto Gil é cantor, compositor e instrumentista e ocupou o cargo de Ministro da Cultura de 2003 a 2008.
} 
perspectiva, Pereira (2018, p. 258) chama de Museologia Decolonial um desdobramento da Museologia Social, que rompe com lógicas museológicas hegemônicas, trazendo para o museu a visibilidade de grupos historicamente marginalizados, assim como formas outras de "ver, sentir, existir, fazer, pensar e escutar".

A consideração de processos museais como parte de uma pedagogia decolonial faz também parte da discussão de Miranda \& Araújo (2019), que abordam a educação para relações étnico-raciais em contextos de educação não formal. A análise comparativa foi o recurso metodológico utilizado para investigar o uso da memória como instrumento para um projeto de valorização de culturas e identidades historicamente subalternizadas. A análise se volta ao Museu da Maré, localizado na cidade do Rio de Janeiro, e ao Fundo Documental AfroAndino, no Equador. Na conclusão, os lugares de memória investigados são ressaltados enquanto possibilidades de trajetórias epistemológicas outras e de pedagogias decoloniais. Algumas das considerações deste texto partem da tese de doutoramento de Araújo (2012) sobre o Museu da Maré, citada na discussão sobre educação não formal, no item 2.1.

A questão das relações étnico-raciais também é o foco de Gil \& Meinerz (2017), que exploram o projeto Territórios Negros: Afro-Brasileiros em Porto Alegre, que serve como campo de estágio para alunos do curso de História da Universidade Federal do Rio Grande do Sul (UFRGS). O projeto engloba vários tipos de ações voltadas à escola e à universidade, vinculadas à lei 10.639/03²3, e consiste basicamente em um percurso feito de ônibus por determinados pontos da cidade, que foca em territórios relacionados à história das populações afrobrasileiras para relembrar e redescobrir suas memórias que, por muito tempo, foram sufocadas pela história considerada oficial.

As autoras ressaltam o quanto africanos e afro-brasileiros sofreram, ao longo do tempo, diversos processos diferentes de desterritorialização, que não necessariamente implicavam no deslocamento forçado das pessoas, mas também envolviam processos de perda de vínculo dos sujeitos com os espaços. Assim, a desterritorialização pode assumir a forma de migrações, remoções, proibição de

${ }^{23}$ A lei 10.639/03 incluiu com obrigatoriedade a história e a cultura afro-brasileiras no currículo das escolas brasileiras nos níveis de ensino fundamental e médio (BRASIL, 2003). 
práticas religiosas ou culturais, substituição de nome de lugares, entre outras ações. De acordo com as autoras, falar em "territórios" negros não é uma referência apenas à falta de território, ou seja, à exclusão dessa camada da população, mas também aos agenciamentos e estratégias cotidianas de sobrevivência dessas pessoas, tanto em nível financeiro como cultural, a táticas diárias para assegurar ou reclamar seu direito aos espaços da cidade.

Por sua vez, Amaral (2015) discute a decolonialidade dentro dos processos de patrimonialização. $\mathrm{O}$ autor, considerando a diversidade de povos que formam o Brasil, coloca em questão o que poderia ser aceito como patrimônio, uma vez que, na Constituição, a noção de patrimônio é definida a partir dos elementos culturais que compõem a identidade nacional. Nessa perspectiva, o autor busca a referência dos teóricos do Grupo Modernidade/ Colonialidade, por estes apresentarem uma orientação investigativa e propositiva de descolonização. Seu objetivo centra-se em analisar a política pública sobre patrimônios culturais no Brasil a partir do pensamento decolonial. A metodologia utilizada para a pesquisa é a autoetnografia. Por meio desta, o autor descreve sua participação no processo de patrimonialização do modo de fazer a viola de cocho no Mato Grosso do Sul e analisa o mesmo.

A partir de uma revisão bibliográfica, Amaral (2015) afirma que a fundação do Instituto Histórico e Geográfico Brasileiro (IHGB) e do Arquivo Nacional, em 1838, marca o início da estruturação da memória e identidades nacionais através da definição de patrimônios históricos. No entanto, a questão patrimonial só viria a ser consolidada durante a presidência de Getúlio Vargas ${ }^{24}$, quando o Serviço do Patrimônio Histórico e Artístico Nacional (SPHAN) é institucionalizado por iniciativa de Gustavo Capanema ${ }^{25}$. Ressalta ainda o autor que os primeiros bens tombados pelo SPHAN eram legados da experiência branca, especialmente portuguesa, católica e ligados à elite política e econômica, o que consolidou uma política patrimonial associada à colonialidade. Posteriormente, as contribuições advindas de culturas indígenas e afro-diaspóricas também seriam vistas como parte do patrimônio. No entanto, ocupariam um lugar menor, como culturas que

\footnotetext{
${ }^{24}$ Presidente do Brasil de 1930 a 1945.

${ }^{25}$ Ministro da Educação do Brasil de 1934 a 1945.
} 
teriam apenas deixado resquícios em um bloco cultural muito mais identificado com a Europa.

A partir da segunda metade do século XX, conforme destaca Amaral (2015), surgem novos paradigmas nas ciências sociais brasileiras, que problematizaram a definição de cultura e a questão da preservação de patrimônios. Nesse tempo, alguns setores da sociedade tiveram uma atuação, considerada pelo autor como de cunho decolonial, de reivindicação pela patrimonialização de locais e construções de referência para as culturas não brancas, principalmente as afro-diaspóricas. Assim, conforme afirma Amaral (2015), da demanda pela valorização das culturas chamadas populares, surge o conceito de patrimônio imaterial. $\mathrm{O}$ autor destaca o Plano de Salvaguarda do Instituto do Patrimônio Histórico e Artístico Nacional (IPHAN) como um instrumento que chama os cidadãos à participação desde a formulação até o acompanhamento da salvaguarda do patrimônio, realçando uma gestão compartilhada e uma autodeterminação daqueles que detém a prática cultural em questão. Nesse sentido, o IPHAN conta com o envolvimento de órgãos como associações, instituições culturais, universidades, o que o autor caracteriza como um modo de gerir de potencial decolonial, uma vez que envolve decisões que não são impostas de cima, a partir de um ideal de cultura, pelo contrário, trata-se de negociações em diálogo com aqueles que vivenciam o elemento cultural a se tornar patrimônio e de ações de valorização de práticas culturais de diversas origens. Portanto, o autor identifica essa forma de patrimonialização como uma maneira de valorização de culturas e saberes outros e também de construção de conhecimento de outro modo.

Posteriormente, ele adensa a narrativa sobre sua participação no processo do Plano de Salvaguarda do modo de fazer viola de cocho, destacando como se desenvolveram as reuniões e as ações que foram planejadas. Entre essas ações, o autor destaca eventos que ocorreram em parceria com museus e escolas locais.

Um ponto destacado a respeito do processo é o fato de que a preservação do modo de fazer viola de cocho é também um movimento de recuperação da cultura do povo Guató, indígenas que ocupam a região do Pantanal desde bem antes da invasão portuguesa e que, com ela, passaram a sofrer processos de desterritorialização, tendo sido durante algum tempo até mesmo considerados extintos. Assim, o processo de salvaguarda do modo de fazer viola de cocho se configurou também como estratégia de (re)existência para os Guató. 
Em sua conclusão, Amaral (2015) ressalta o potencial decolonizador da patrimonialização, apontando também seus limites, como uma eventual desvinculação do bem a se tornar patrimônio do universo cultural que lhe confere sentido e também sua possível fetichização.

A partir da revisão bibliográfica aqui apresentada, foi possível perceber que grande parte dos estudos que ligam a temática do museu à perspectiva decolonial investiga a questão da educação de relações étnico-raciais e da luta antirracista, sendo comum também a abordagem quanto à recuperação e à preservação da memória de povos historicamente subalternizados e a reflexão a respeito das formas de patrimonialização.

Em relação ao levantamento bibliográfico sobre o MAR, no portal de periódicos da CAPES, foram encontrados 181 resultados para artigos; no catálogo de teses e dissertações da CAPES, 9 resultados; na base SciELO, 2 resultados; no Google Acadêmico, foram encontrados 901 resultados sem incluir patentes ou citações e restringindo ao português, dos quais foram selecionados os 30 primeiros resultados que o site colocou como mais relevantes. Foi feita uma primeira seleção dos textos a partir dos títulos e, posteriormente, uma segunda seleção a partir da leitura dos resumos.

Entre os temas que apareceram de modo mais recorrente, destacam-se:

- Exposições específicas ocorridas no museu;

- Educação museal, setor educativo, mediação e visita guiada;

- Contexto de surgimento do MAR, megaeventos e a reabilitação do edifício;

- Curadoria e coleção;

- Políticas culturais e modelos de gestão.

Os dados obtidos nesse primeiro levantamento bibliográfico sobre o MAR foram incorporados aos dados coletados posteriormente, na segunda fase da pesquisa, explicitada no item a seguir. É importante destacar que esse primeiro levantamento mostrou que grande parte dos estudos sobre o MAR ressalta seu caráter inovador e dá grande foco ao seu projeto educativo e ao seu contexto de surgimento. Entretanto, não foram encontrados estudos que abordem as características inovadoras deste museu por uma via decolonial. Assim, atestou-se 
a carência de bibliografia sobre o MAR apoiada no referencial teórico dos estudos da decolonialidade. É necessário destacar ainda que a ideia de interculturalidade foi recorrente em artigos sobre a exposição de temática indígena, Dja Guata Pora $\tilde{a}^{26}$.

\section{2}

\section{Segunda etapa: Coleta de dados}

A etapa de coleta de dados ocorreu em duas fases. Na primeira, foram utilizados os dados dos questionários aplicados pelo GEPEMCI em dois períodos, o primeiro compreendendo os anos de 2015 e 2016 e o segundo, os anos de 2019 e 2020. A partir desses dados, foi traçado um perfil comparativo do MAR frente aos demais museus da cidade do Rio de Janeiro, destacando-se algumas questõeschave que transpareceram através das respostas.

$\mathrm{Na}$ segunda fase, foram utilizados como fontes na análise bibliográfica e documental:

- O material de divulgação do museu em meio digital, disponível nas redes sociais, como Facebook, Twitter e Instagram, na página do YouTube e no site da instituição;

- Os catálogos das exposições;

- Material bibliográfico acadêmico e jornalístico.

O corpus obtido foi separado de acordo com o tipo de documento nos seguintes grupos:

1. Teses, dissertações e monografias

2. Outros tipos de documentos escritos

3. Vídeos e o evento em comemoração aos 7 anos do MAR, no qual tive a oportunidade de comparecer

Depois de explorado e categorizado, o material foi, então, interpretado à luz do referencial teórico.

Para a interpretação, apresentada no capítulo 4, foram considerados os temas mais abordados no material e que permitiam a visão panorâmica almejada

\footnotetext{
${ }^{26}$ Dja Guata Porã: Rio de Janeiro indígena (05/2017 - 03/2018), curadoria de Sandra Benites, José Ribamar Bessa Freire, Pablo Lafuente e Clarissa Diniz.
} 
aqui. Como será possível notar no quarto capítulo, nem todo o material foi diretamente citado. Todavia, a interpretação foi construída a partir da análise do material como um todo.

A fim de permitir ao leitor a mesma visão panorâmica, esta foi separada em três ângulos e ilustrada a partir de três exposições que passaram pelo MAR. O primeiro ângulo se volta ao contexto de abertura do MAR, sua gestão por Organização Social (OS) e a possibilidade de aplicação do conceito de brechas decoloniais ao MAR e à sua história. A mostra que ilustra esse primeiro ponto é $O$ Abrigo e $O$ Terreno $^{27}$. No segundo ângulo, busca-se a visão de um museu-escola, a partir das práticas da Escola do Olhar e também da possibilidade de aplicação do conceito de interculturalidade ao MAR. A mostra Dja Guata Porã é a que ilustra esse segundo ponto. Por fim, é apresentada a situação mais recente do MAR, incluindo a sua crise financeira e de gestão de 2019 e também suas práticas ao longo do período de pandemia de 2020, no qual os museus do Rio de Janeiro ficaram fechados. Essa última questão é ilustrada pela mostra Casa Carioca $^{28}$.

\section{3 \\ MAR à vista - O MAR nos questionários do GEPEMCI}

O primeiro questionário (Q1) do GEPEMCI foi aplicado ao longo dos anos de 2015 e 2016. Responderam ao questionário 85 instituições, entre museus, centros culturais e instituições afins da cidade do Rio de Janeiro. O questionário foi elaborado com 30 questões. O segundo questionário (Q2) possuía 47 questões e foi aplicado ao longo dos anos de 2019 e 2020. Devido ao fechamento dos museus em decorrência da pandemia, o contato com eles foi prejudicado. Assim, foi obtido um número menor de respostas, apenas 62. No caso do MAR, ambos os questionários foram respondidos por alguém que se identificou como integrante da coordenação do museu. Isso não significa que tenha sido a mesma pessoa que respondeu a ambos os questionários, uma vez que o respondente não informa seu nome, mas apenas seu cargo na instituição.

Foram selecionadas as respostas mais relevantes para os objetivos da pesquisa. Os quadros a seguir comparam alguns dos dados correspondentes ao MAR com os dados das demais instituiçõos.

${ }^{27}$ O Abrigo e o Terreno (03/2013 - 07/2013), curadoria de Paulo Herkenhoff e Clarissa Diniz.

${ }^{28}$ Casa Carioca (09/2020 - 09/2021), curadoria de Marcelo Campos e Joice Berth. 
Quadro 2. Respostas sobre a tipologia das instituições no Q1 (Respostas abertas)

\begin{tabular}{|l|l|}
\hline Resposta do MAR & Museu de Arte \\
\hline Respostas coincidentes & 5 \\
\hline Respostas parecidas & 6 \\
\hline Outras respostas & 73 \\
\end{tabular}

(Elaborado pela autora)

Quanto à tipologia, é importante destacar que, no Q1, algumas instituições indicaram mais de uma tipologia, outras deram respostas ambíguas, como as que se referiam à instituição como "interativo", "expositivo", "museu” ou "temático", algumas também responderam com a sigla da instituição. Estas respostas foram contabilizadas como "outras respostas". No entanto, é essencial também mencionar que algumas entre estas instituições são reconhecidamente museus de arte ou centros culturais voltados à arte, tais como o Museu de Arte Moderna do Rio de Janeiro (MAM) e o Centro Cultural Banco do Brasil (CCBB).

Entre os que deram respostas parecidas, estão os que definiram a sua tipologia como de centro ou espaço cultural, museu de arte popular brasileira, arte sacra e arte e meio ambiente. Entre os que se definiram pela mesma tipologia do MAR estão o Museu Internacional de Arte Naif (MIAN) ${ }^{29}$, os Museus Castro Maia/ Chácara do Céu, o Museu Nacional de Belas Artes (MNBA), o Museu Bispo do Rosário de Arte Contemporânea e o Museu Dom João VI.

Quadro 3. Resposta sobre a tipologia das instituições no Q2 (Com opções de resposta)

\begin{tabular}{|l|l|}
\hline Resposta do MAR & Artes visuais \\
\hline Respostas coincidentes & 19 \\
\hline Outras respostas & 42 \\
\hline
\end{tabular}

(Elaborado pela autora)

Como é possível observar, o MAR deu uma resposta diferente no Q2. Isso se deve ao fato de que essa versão do questionário oferecia opções de respostas. Foram utilizadas como opções as tipologias da classificação do Cadastro Nacional de Museus do Instituto Brasileiro de Museus (IBRAM). Assim, evitaram-se os equívocos ocorridos no questionário anterior. Nota-se também que mais instituições se alinharam com o MAR em relação à sua tipologia, sendo elas: o MAM, Museu Histórico Nacional (MHN), Museu Vivo NAMI, Museu Arquidiocesano de Arte Sacra, Museu Dom João VI, Museus Castro Maya, Centro Nacional de Folclore e Cultura Popular, Igreja da Santa Cruz dos

${ }^{29}$ Como será possível notar, o MIAN, que possuía muitas respostas coincidentes com o MAR no Q1, não aparece nos dados do Q2. Essa ausência se deve ao fato de que esta instituição está fechada desde dezembro de 2016. 
Militares, Museu Provedor Mauro Ribeiro Viegas, MNBA, Museu Carmen Miranda, Instituto Cultural Cravo Albin, Museu Bispo do Rosário, Casa Museu Eva Klabin, Centro Cultural Correios, Solar Grandjean de Montigny, Centro Cultural do Movimento Escoteiro, Instituto Casa Roberto Marinho e Museu Judaico.

Quadro 4. Respostas à pergunta "A instituição oferece programações específicas para quais audiências?" no Q1 (Com opções de resposta e espaço "outro", para acrescentar respostas indisponíveis nas opções)

\begin{tabular}{|l|l|}
\hline Resposta do MAR & $\begin{array}{l}\text { Escolar - creche, pré-escola, ensino } \\
\text { fundamental I e II e ensino médio, ensino } \\
\text { superior, pessoas com deficiência, professores, } \\
\text { famílias, turistas, idosos, vizinhos }\end{array}$ \\
\hline Respostas coincidentes & 9 \\
\hline Outras respostas & 75 \\
\hline
\end{tabular}

(Elaborado pela autora)

No Q1, o MAR marcou todas as opções de resposta em relação ao oferecimento de programações específicas para audiências particulares. Além disso, o museu foi o único a mencionar "vizinhos" na opção "outro", mas outros museus, ainda que em número reduzido, se referiram à população do entorno de outras formas. Marcaram também todas as opções, portanto, dando a mesma resposta que o MAR, as seguintes instituições: Casa da Ciência da Universidade Federal do Rio de Janeiro (UFRJ), Museu Casa do Pontal, MIAN, CCBB, MAM, Museu Bispo do Rosário, Fundação Planetário, Casa Daros e Jardim Zoológico.

No entanto, no Q2, o MAR deu outra resposta, afirmando ter programação específica para: educação infantil (0-5 anos), ensino fundamental I, ensino fundamental II, ensino médio, ensino superior, professores, famílias e idosos. Apenas uma instituição marcou exatamente as mesmas opções, o Espaço Ciência Viva. Todas as demais variaram em ao menos uma opção.

Outra observação a ser feita sobre o Q1 é que a audiência menos contemplada com programações específicas parece ser a de creche (crianças com idade entre 0 e 3 anos). Das 75 instituições que marcaram outras respostas, 20 afirmaram não oferecer programação para nenhum grupo específico e das 55 que oferecem, 50 não marcaram a opção de oferecimento para o público de creches. Isso significa que $42,5 \%$ do total das instituições excluíram este grupo no oferecimento de programações específicas. No Q2, a educação infantil, desta vez compreendendo o grupo de crianças entre 0 e 5 anos, também aparece como uma 
das menos contempladas com programações específicas, ficando atrás apenas de idosos.

Devido à observação quanto à exclusão de crianças pequenas no oferecimento de programações específicas, mostrou-se pertinente, portanto, trazer a resposta em relação à frequência desse público nos espaços.

Quadro 5. Respostas à pergunta "Em comparação com os demais públicos, qual é a frequência de visitas das crianças à instituição? [0-3 anos]" no Q1 (Com opções de resposta)

\begin{tabular}{|l|l|}
\hline Resposta do MAR & Alta \\
\hline Muito alta/ Alta & 7 (excluindo-se o MAR) \\
\hline Média/ Baixa & 26 \\
\hline Muito baixa/ inexistente & 51 \\
\hline
\end{tabular}

(Elaborado pela autora)

Quadro 6. Respostas à pergunta "Em comparação com os demais públicos, qual é a frequência de visitas das crianças à instituição? [0-3 anos]" no Q2 (Com opções de resposta)

Resposta do MAR

\begin{tabular}{|l|l|}
\hline Muito alta/ Alta & 3 \\
\hline
\end{tabular}

Média/ Baixa $\quad 18$ (excluindo-se o MAR)

Muito baixa/ inexistente

(Elaborado pela autora)

Responderam, no Q1, que a frequência de visitas de crianças entre 0 a 3 anos é alta ou muito alta as seguintes instituições: MIAN, Centro Cultural Parque das Ruínas, Museu Nacional, Museu Bispo do Rosário, Museu Casa de Rui Barbosa, Casa Daros e Jardim Zoológico. Já no Q2, deram esta resposta as seguintes instituições: MHN, Parque das Ruínas e Musehum - Museu das Comunicações e Humanidades. A Casa de Rui Barbosa, no Q2, deu a mesma resposta que o MAR, média.

O MAR respondeu, no Q1, que também é alta a frequência de crianças entre 4 e 5 anos e é muito alta a de crianças entre 6 e 10 anos. Já no Q2, o museu afirmou ser média a frequência de crianças entre 4 e 6 anos e muito alta a de crianças entre 7 e 10 anos.

Analisando as respostas às duas questões anteriores, 2 e 3, é possível questionar se a frequência baixa de crianças entre 0 e 3 se deve ao não oferecimento de programação específica para esta audiência ou se o não oferecimento é devido à baixa frequência. Assim, a questão a respeito de a instituição possuir iniciativas para atrair as crianças de 0-5 anos se mostra relevante. Para esta pergunta, a resposta do MAR, no Q1, foi positiva, assim como a de 25 instituições, enquanto 59 responderam que não possuem iniciativas para atrair esta audiência. Logo, pode-se observar que um número considerável de instituições não possui uma programação específica para crianças entre 0 e 3 anos, 
não tem iniciativas para atrair este público e possui uma frequência inexistente ou muito baixa do mesmo. Por outro lado, o MAR estaria dentro da minoria que possui programação específica, tem iniciativas de atração do público de crianças entre 0 e 3 anos e o recebe com frequência alta, tendo possivelmente diminuído essa frequência com o passar dos anos, de modo que, no Q2, ela passou a ser média.

No Q1, o MAR menciona como iniciativas para a atração desta audiência as seguintes: visitas educativas com foco no público escolar e ações educativas. Além disso, afirma que disponibiliza para este grupo de espaço para acolhimento e para alimentação e que o atendimento é feito na área externa e na expositiva. As atividades oferecidas para as crianças desta faixa etária são as seguintes: jogos e brincadeiras, contação de história, visita mediada e oficina.

No Q2, o MAR afirma que oferece como atividade para esta faixa etária oficinas, visitas mediadas com a família e visitas mediadas com grupos escolares. Além disso, o museu diz que disponibiliza para crianças entre 0 e 6 anos apenas banheiro familiar e fraldário e que todas as dependências do museu são usadas para o atendimento deste grupo. Em relação a considerar se deveria ocorrer alguma mudança para a realização do trabalho com o público infantil, no Q1, o MAR respondeu que não, mas, no Q2, a resposta foi positiva, apontando os seguintes itens: mobiliário adequado, espaço expositivo acessível, espaço de acolhimento.

Algumas hipóteses podem explicar as mudanças nas respostas do MAR em relação ao grupo de crianças menores de 6 anos. A primeira delas se refere à diminuição do investimento financeiro público no museu, que pode ter impactado nas ações do setor educativo e até mesmo no transporte de determinados grupos até o espaço. Esta hipótese se baseia na análise dos vídeos do seminário $O$ Terceiro Setor na Gestão da Cultura $^{30}$ e também na análise do evento \#MARé ${ }^{31}$. Em ambos os eventos, são discutidas as formas de financiamento do MAR e são mencionadas diminuições nos repasses de verba pública para a organização social (OS) que administra o museu, o Instituto Odeon. A segunda hipótese diz respeito

\footnotetext{
${ }^{30}$ MUSEU DE ARTE DO RIO. Seminário "O Terceiro Setor na Gestão da Cultura"| Pt. 1. 29 mar. 2017. (2h38m52s). Disponível em: https://youtu.be/ZRdTNra3MpU. Acesso em: 15 fev. 2020.

${ }^{31}$ MUSEU DE ARTE DO RIO. \#MARé. Rio de Janeiro: Museu de Arte do Rio (MAR), 12 fev. de 2020.
} 
à mudança recente na coordenação da Escola do Olhar. Em março de 2020, Izabela Pucu deixou a coordenação, sendo substituída no cargo por Hugo Oliveira. Assim, é possível que o questionário tenha sido respondido por alguém que ainda não estava completamente familiarizado com os públicos recebidos pelo museu e teve uma perspectiva mais pessimista.

Em relação ao atendimento a pessoas com deficiência, no Q1, o MAR informou utilizar ou já ter utilizado nas exposições ou atividades educativas os seguintes recursos: livro em Libras e legenda, maquete tridimensional, videoguides-surdos, interação com o tato, audioguides-cegos, áudio descrição e Libras $^{32}$. Além disso, afirmou oferecer os seguintes recursos estruturais: portas e corredores largos, banheiros adaptados, rampa de acesso, elevadores, piso tátil e corrimão. Já no Q2, como recursos de acessibilidade, a instituição informou oferecer portas e corredores largos, banheiros adaptados, rampa de acesso, elevadores, piso tátil, corrimão, interação com o tato, braile e Libras.

Quanto a possuir um plano educacional, no Q1, o MAR respondeu que sim, junto a 40 instituições, enquanto 44 responderam negativamente. Além disso, o MAR afirmou, em ambos os questionários, que possui verba fixa para o desenvolvimento de ações educativas. No Q1, 15 instituições deram a mesma resposta, enquanto 69 instituições responderam que não recebem verba ou apenas recebem eventualmente. Já no Q2, 14 responderam positivamente, enquanto 47 disseram não receber verba ou receber eventualmente.

Em relação a possuir um setor educativo, o MAR respondeu que sim, junto a 43 outras instituições, enquanto 41 disseram que não possuem. $\mathrm{O}$ nome desse setor no MAR, segundo o Q1, é Gerência de Educação, mas, de acordo com o Q2, é Coordenação de Educação. Verificou-se, posteriormente, com a análise dos vídeos e dos textos escritos por membros da própria equipe e disponibilizados no site do museu, que esta nomenclatura, assim como a do trabalhador a frente do setor, varia a depender do interlocutor ou autor, além de também se transformar muito ao longo do tempo, seguindo as próprias mudanças do setor em relação ao quadro de trabalhadores, que pode aumentar ou diminuir de acordo com o aporte financeiro, e a atribuição de cargos. Assim, por exemplo, já houve na instituição

\footnotetext{
${ }^{32}$ Embora no questionário o museu não especifique de que maneira a Libras é utilizada, no site, a instituição informa que são oferecidas visitas mediadas em Libras todo domingo.
} 
uma pessoa responsável pela Gerência de Educação, chamado gerente de educação, e outra pela Coordenação de Educação, denominado coordenador. Mas, em outros períodos, havia apenas uma pessoa responsável pela gestão do setor educativo ou, em denominação específica dada tanto ao setor quanto ao edifício em que ele funciona, pela Escola do Olhar.

No Q1, na questão em que se perguntava quanto às pesquisas científicas do setor educativo, o MAR ofereceu um dado sobre o seu funcionamento:

Os educadores da Gerência de Educação se dividem em 4 grupos de estudos fixos, dirigidos por um educador de projetos e acompanhados pela coordenadora pedagógica. É através dos grupos de trabalho que as pesquisas sobre as exposições e metodologias de educação são realizadas. Os grupos são: "Eu, a cidade e o outro", "Forma, Imagem e Palavra", "Acessibilidade" e "Narrativas Fantásticas". Mas as pesquisas nos GT's não se caracterizam como científicas. (Questionário GEPEMCI 2015/2016, resposta do MAR).

Como será discutido no item 4.1.2, esta organização em grupos de trabalho deixou de existir devido a uma reestruturação da equipe por diminuição orçamentária.

Quanto ao referencial teórico no qual o setor educativo se baseia para suas atividades, no Q1, a resposta foi a seguinte:

Cada grupo de trabalho tem referenciais teóricos e artísticos próprios, a partir dos quais as atividades e debates sobre arte, educação e cultura visual se estruturam. Podemos destacar Jaques Ranciere, Gilles Deleuze, Felix Guatarri, Sueli Rolnik, Judith Butler, Beatriz Paul Preciado, Michel de Certeau, George Yúdice, Aby Warburg, Paulo Freire, Jorge Luiz Borges, Stuart Hall, Michel Foucault, Hal Foster, Giovana Xavier, Conceição Evaristo, Peter Pál Pelbart, Paola Berentein, Antonio Negri, Ricardo Basbaum e Vilém Flusser. (Questionário GEPEMCI 2015/2016, resposta do MAR).

Entretanto, no Q2, o museu citou apenas Paulo Freire como referência. Como explicação para esta escolha a instituição afirmou:

Porque ele colabora com o pensamento referencial de nossas práticas como, autonomia, não hierarquização dos saberes, emancipação, a aprendizagem a partir dos referenciais do outro no processo educativo, foco na dialética, a experiência coletiva de criação da educação e a questão da estética indissociável da ética. (Questionário GEPEMCI 2015/2016, resposta do MAR).

O museu também informou, no Q1, que a maioria das pessoas do setor educativo possui como nível educacional o ensino superior, com formação nas seguintes áreas: Artes Visuais, Museologia, Educação, História, Cinema, Filosofia, Economia, Educação Física, Letras e Comunicação Social. No Q2, a 
instituição informou que a maioria já cursou ou ainda está cursando o ensino superior, nas seguintes áreas: Artes, Comunicação (Jornalismo, Mídias Digitais, Publicidade), História, Museologia e Pedagogia.

Além disso, o MAR afirmou, em ambos os questionários, que o setor educativo avalia as ações desenvolvidas por meio de entrevistas e questionários com o público espontâneo e com o público escolar, relatórios administrativos, reuniões com a equipe e observação. Cabe ainda mencionar a informação dada em ambos os questionários de que a participação do setor educativo nas exposições é eventual.

\section{4}

\section{As ondas do MAR online}

O MAR pode ser encontrado em meio digital nos seguintes endereços:

- Site: http://museudeartedorio.org.br

- Twitter: https://twitter.com/MuseuArteRio

- Facebook: https://www.facebook.com/museudeartedorio

- Instagram: https://www.instagram.com/museudeartedorio

- YouTube: https://www.youtube.com/user/Museudeartedorio

No site, o museu disponibiliza ampla informação sobre suas exposições, cursos, oficinas, catálogos, livros, publicações e outras atividades oferecidas. O site pode ser lido em português, inglês, espanhol e é também acessível em Libras.

A conta do MAR no Twitter foi criada em agosto de 2012 e até agosto de 2020 possuía 27 mil seguidores. A grande maioria das publicações é de divulgação dos eventos e demais atividades do museu, sejam elas presenciais ou virtuais, ou ainda de comentário sobre alguma temática relacionada ao que é oferecido. O público interage pouco e a forma de interação mais constante é a curtida ${ }^{33}$.

A conta no Facebook foi criada na mesma época e até agosto de 2020 contava com um total de 195.728 pessoas que curtiram e 199.177 seguidores,

\footnotetext{
${ }^{33} \mathrm{O}$ Twitter oferece três opções de interação: (1) Responder - Trata-se de comentar a publicação de outro usuário, na própria publicação, dando sua opinião; (2) Retwittar - Consiste em compartilhar a publicação de outro, tendo a opção de acrescentar um comentário próprio, mas criando uma nova publicação; (3) Curtir - Consiste em marcar um ícone em forma de coração como uma maneira de mostrar que gostou ou concorda com o que foi publicado.
} 
além de 165.450 registros de check-in ${ }^{34}$. As publicações são as mesmas do Twitter e a interação do público também não é muito frequente, sendo a curtida mais uma vez a forma de interação mais constante. Além destas publicações, na aba de fotos e vídeos é possível ter acesso a registros de algumas atividades do museu. Grande parte dos vídeos possui por volta de mil visualizações. Na aba de avaliações, a instituição recebeu de 282 visitantes a média $4.9^{35}$. Além de escrever muitos elogios, principalmente ao espaço físico do museu, a maioria dos visitantes também publicou fotos de suas visitas.

No Instagram, o MAR possuía, em agosto de 2020, 170 mil seguidores. Embora as publicações sejam, em sua maioria, as mesmas das outras duas redes, esta é aquela em que o público interage com maior frequência. O público não só curte mais as publicações do MAR no Instagram, como a interação por meio de comentários é bem mais constante em comparação com as demais redes. Suas publicações, que antes possuíam por volta de 500 curtidas, na época da pandemia, passaram a ter por volta de mil.

Através de seu site e de suas redes, é possível ver que o museu possui alguns eventos e atividades permanentes e outras esporádicas ${ }^{36}$. Algumas delas são as seguintes:

- Bebês no MAR - Uma oficina voltada para crianças de 0 a 2 anos, que acontece no espaço expositivo, na biblioteca e nas salas multiuso, todo primeiro sábado do mês.

- \#MARAberto - Uma proposta de descobrir outros modos de se habitar um museu.

- Universidade das Quebradas (UQ) - Um projeto coordenado por Heloísa Buarque de Hollanda e Numa Ciro, que acontece em uma parceria entre o MAR e Faculdade de Letras da UFRJ. A UQ realiza um curso voltado a artistas e agentes culturais.

\footnotetext{
${ }^{34}$ O Facebook dá ao usuário a opção de curtir e seguir separadamente. Ao curtir, o usuário demonstra o interesse pela atividade a que a página em questão se dedica e, ao seguir, recebe atualizações sobre o que é publicado na página. As páginas que se referem a espaços possuem ainda a opção de fazer check-in, que permite ao usuário marcar em sua própria publicação que esteve no determinado lugar, geralmente publicando uma foto.

${ }^{35}$ A nota máxima para avaliações no Facebook é 5.0.

${ }^{36}$ Durante o período de pandemia, quando o museu se manteve fechado, todas as atividades presenciais foram suspensas. Entretanto, algumas delas foram retomadas em formato virtual, no segundo semestre de 2020, como o Vizinhos do MAR.
} 
- Vizinhos do MAR - Um programa que elabora atividades visando a criação de uma plataforma de diálogo, experiência e ação entre o museu, moradores, coletivos e instituições do entorno. Como parte do programa, existe ainda o evento mensal chamado Café com Vizinhos, um café-damanhã oferecido no museu para os moradores da região como um espaço de conversa sobre as ações da instituição e as necessidades e aspirações locais. Além disso, há ainda a produção de um jornal, que aborda temas de interesse do museu e da região portuária ${ }^{37}$ e é feito em coletividade com os moradores. Atualmente o jornal está em sua segunda edição e pode ser baixado no site do museu.

- MAR na Rua - Uma websérie no YouTube, que discute o vínculo das obras da coleção com a história narrada por moradores do entorno.

- \#MARdecasa - Um projeto que visa manter o MAR funcionando durante o tempo de isolamento social de 2020. Como parte do projeto, o museu lançou um podcast, a consulta online ao acervo, o tour virtual por algumas exposições, entre outras ações.

Foi feita uma análise flutuante das publicações do MAR em suas redes e em seu site, seguida por uma aproximação mais detalhada de algumas publicações e alguns materiais disponíveis no site.

Todos os vídeos que compõem o corpus de pesquisa foram retirados do canal do YouTube do museu, no endereço eletrônico https://www.youtube.com/Museudeartedorio. Foram feitos relatórios sobre os vídeos e sobre o evento \#MARé. No YouTube, o MAR possuía até agosto de 2020 um total de 6,56 mil inscritos em seu canal. Devido ao amplo material oferecido pela instituição nesta rede, ela constituiu uma das principais fontes desta pesquisa. A princípio, a intenção era a de trabalhar com todo o material publicado no canal. No entanto, depois que a coleta começou a ser feita, percebi que seria necessário fazer escolhas. Dessa maneira, os vídeos já assistidos ou até mesmo o material bibliográfico indicavam quais seriam os vídeos que mais poderiam contribuir com a análise. Por exemplo, existia um número significativo de artigos sobre a exposição Dja Guata Porã. Assim, foram privilegiados vídeos relativos a esta

37 Região portuária é como é conhecida a área do centro da cidade do Rio de Janeiro que compreende a área ao redor da Praça Mauá e os bairros da Gamboa, Saúde e Santo Cristo. 
mostra. Ao final, foram analisados 95 vídeos, que juntos totalizaram mais de 74 horas e 182 páginas de relatório. A última seleção dos vídeos foi realizada no dia 17 de agosto de 2020. Desse modo, qualquer vídeo publicado pelo MAR posteriormente não entrou na análise.

Foi selecionado para análise o seguinte material:

Quadro 7. Organização dos vídeos selecionados para análise.

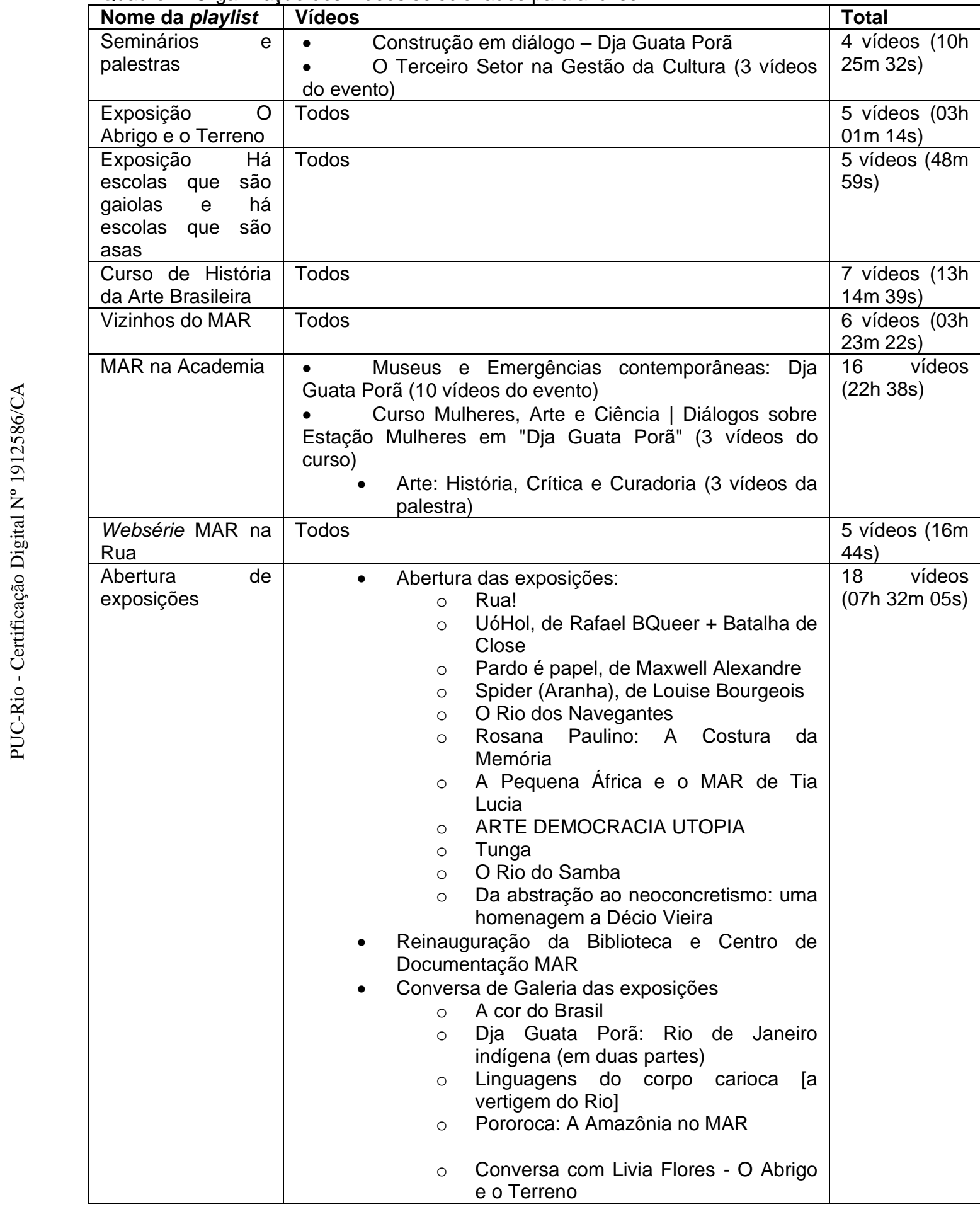




\begin{tabular}{|c|c|c|}
\hline $\begin{array}{l}\text { Curso arte, ação e } \\
\text { pensamento } \\
\text { decoloniais/ } 2019\end{array}$ & Todos & 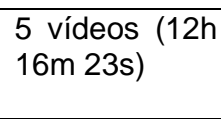 \\
\hline $\begin{array}{l}\text { Percursos } \\
\text { mediados - O Rio } \\
\text { dos Navegantes }\end{array}$ & Todos & $\begin{array}{l}5 \text { vídeos }(20 \mathrm{~m} \\
38 \mathrm{~s})\end{array}$ \\
\hline Casa Carioca & Todos & $\begin{array}{lr}19 & \text { vídeos } \\
\text { (01h } 39 \mathrm{~m} 43 \mathrm{~s})\end{array}$ \\
\hline Total & & $\begin{array}{lr}95 & \text { vídeos } \\
(74 \mathrm{~h} & 59 \mathrm{~m} \\
57 \mathrm{~s}) & \\
\end{array}$ \\
\hline
\end{tabular}

(Elaborado pela autora)

Em relação ao material bibliográfico disponibilizado no site, após a seleção, foi feita a leitura e revisão de literatura em fichas, que gerou um total de 26 páginas. Foram selecionados para análise os seguintes documentos:

Quadro 8. Material bibliográfico disponibilizado no site do MAR

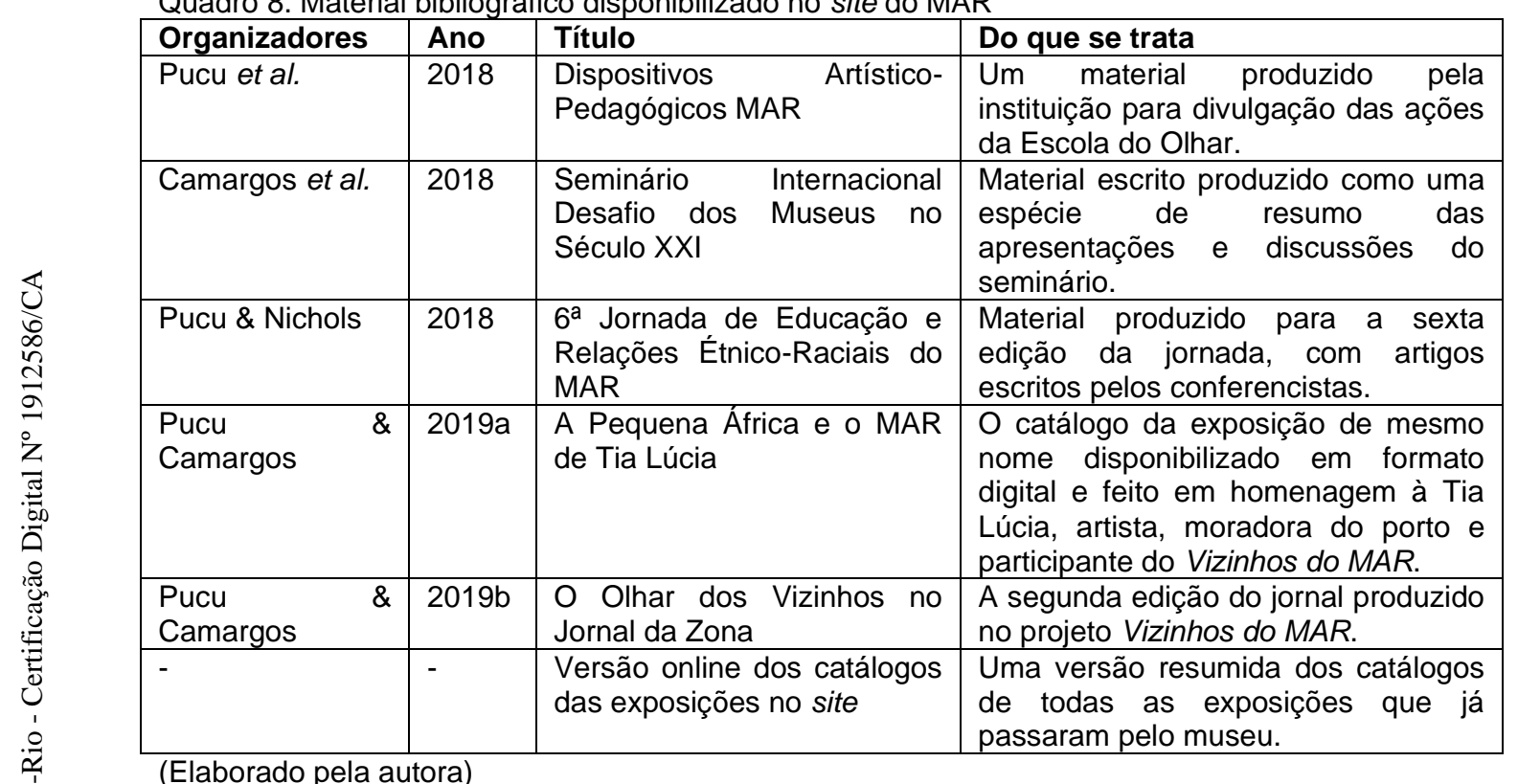

\section{5}

\section{As ondas do MAR nos catálogos}

Também fizeram parte do corpus os catálogos físicos do MAR. Foram analisados os catálogos das seguintes exposições:

Quadro 9. Catálogos de exposições

\begin{tabular}{|l|l|l|}
\hline Organizadores & Ano & Título da exposição \\
\hline Diniz & 2014 & Pernambuco Experimental \\
\hline Diniz \& Cardoso & 2015 & Do Valongo à Favela: Imaginário e periferia \\
\hline Anjos & 2018 & Arte, Democracia e Utopia: quem não luta tá morto \\
\hline Salles et al. & 2018 & O Rio do Samba: resistência e reinvenção \\
\hline Equipe MAR & 2019 & Mulheres na coleção MAR \\
\hline Salles et al. & 2019 & O Rio dos navegantes \\
\hline
\end{tabular}

(Elaborado pela autora) 
Foram produzidos relatórios de análise dos catálogos. Esta análise se deu em três eixos: (1) aspectos materiais; (2) aspectos textuais; (3) textos de abertura de Carlos Gradim, diretor-presidente do Instituto Odeon. A escolha pela análise dos textos escritos por Gradim em específico se deu por este ser um elemento comum a todos os catálogos, com a exceção de Mulheres na Coleção MAR, cujo único texto não escrito por uma mulher é assinado por Evandro Salles, então diretor cultural do museu.

Quanto ao primeiro e ao segundo eixos, foi observado que os catálogos de Pernambuco Experimental e Do Valongo à Favela diferem dos demais em três aspectos: (1) tamanho, (2) material e (3) linguagem. Os catálogos das exposições de 2018 e 2019 são padronizados. Todos possuem a dimensão de $15 \times 21 \mathrm{~cm}$, o papel utilizado é de tipo offset e os textos são mais curtos e possuem uma linguagem bem acessível, lembrando um guia turístico. Já os catálogos das duas exposições anteriores são maiores, o de Pernambuco Experimental mede 20x 24cm e o de Do Valongo à Favela, 22x28cm. Além disso, são feitos em papel couché e seus textos são maiores, possuem subtítulos, bibliografia e identificação de autor, além de uma linguagem mais acadêmica.

Há também uma diferença muito evidente entre esses dois grupos de catálogos em relação ao terceiro eixo. Da mesma maneira que os demais textos dos catálogos, a linguagem utilizada por Gradim nos textos de abertura é de tipo mais acessível nas obras de 2018 e 2019 e os textos são também menores em comparação com os dos catálogos de 2014 e 2015. Além disso, nos catálogos mais recentes, ele não faz nenhuma menção em relação ao financiamento, tema que ocupou um longo parágrafo de Pernambuco Experimental. Neste catálogo, Gradim menciona que este seria um terceiro módulo de uma trilogia curatorial de Paulo Herkenhoff, composta por duas exposições que ocorreram anteriormente em Recife, Pernambuco Moderno e Pernambuco Contemporâneo, porém, desta vez a curadoria seria de Clarissa Diniz. Segundo Gradim,

Pernambuco Experimental lançou luz sobre outros projetos de modernidade, ideias de país, experiências de arte e conformações sensíveis. Trata-se, assim de uma mostra que reagiu criativa e criticamente às zonas de conforto da cultura - esforço 
continuado com o qual se compromete o Museu de Arte do Rio. (GRADIM, 2014, p. 9$)^{38}$.

Já no catálogo de Do Valongo à Favela, Gradim $\left(2015\right.$, p. 7) ${ }^{39}$ caracteriza a exposição como parte do projeto do MAR em assumir uma identidade associada ao Rio de Janeiro, adotando a história desta cidade como temática central, mas fazendo uma leitura dela de maneira a "expor, enunciar e visibilizar aquilo que sofreu, anos a fio, tentativas de apagamento e invisibilização". Além disso, afirma que a exposição fez também parte de um projeto maior que visa vincular o museu ao seu entorno, a área conhecida como Pequena África. Gradim utiliza um discurso bem parecido em seu texto de abertura do catálogo de O Rio do Samba, no qual ainda parabeniza o MAR pelos seus "5 anos de diversidade, encontros, acolhimento, pertencimento e também de resistência e reinvenção" (GRADIM, 2018 , p. 7$)^{40}$. Já a exposição $O$ Rio dos Navegantes é descrita por Gradim como o fechamento de um ciclo, do qual $O$ Rio do Samba faz parte, mas que teve seu início com $O$ Rio de Imagens, formando com estas mostras o retrato de um Rio que se vê, se escuta e se constrói, ou ainda que é composto por uma riqueza de natureza, cultura e trabalho.

A exposição Arte, Democracia e Utopia, cujo tema principal foi a política, conforme afirma Gradim, faz parte do programa Arte e Sociedade, que teve seu primeiro momento com a exposição $O$ Abrigo e o Terreno, que apresentou como tema a moradia, sucedida por Há escolas que são gaiolas e há escolas que são asas, cujo tema era a educação. O programa visa discutir questões polêmicas e de interesse do país.

\section{6}

\section{As ondas do MAR na academia e na mídia}

Foi feita uma revisão bibliográfica de um total de 20 textos acadêmicos e jornalísticos escritos sobre o MAR.

\footnotetext{
${ }^{38}$ GRADIM, C. Apresentação. In: DINIZ, C (org.). Pernambuco Experimental. Rio de Janeiro: Instituto Odeon, 2014.

39 GRADIM, C. Apresentação. In: DINIZ, C.; CARDOSO, R. (org.). Do Valongo à Favela: Imaginário e periferia. Rio de Janeiro: Instituto Odeon, 2015.

${ }^{40}$ GRADIM, C. Apresentação. In: SALLES, E. et al. (org.). O Rio do Samba: resistência e reinvenção. Rio de Janeiro: Instituto Odeon, 2018.
} 
Em relação aos documentos escritos, foram também produzidos relatórios nos quais o material coletado foi fichado e categorizado de acordo com os seguintes critérios:

1) Tipo de material: (a) material acadêmico, (b) textos jornalísticos, (c) material de divulgação do museu, (d) catálogo de exposições

2) Frequência do tema "MAR": (a) baixa, (b) média, (c) alta

3) Eixo do museu abordado: (a) ações do setor educativo, (b) aspectos curatoriais, (c) demais aspectos

4) Questões de destaque

Em relação à frequência do tema, os documentos foram categorizados da seguinte maneira:

1. Baixa: Foram considerados documentos que falam sobre o MAR com uma frequência baixa aqueles em que o nome do museu ou de seus projetos, considerando os nomes das exposições, do projeto Vizinhos do MAR e da Escola do Olhar não aparecem no título do texto e aparecem na posição de sujeito de até cinco orações.

2. Média: Foram considerados documentos que falam em frequência mediana sobre o MAR aqueles em que o nome do museu ou de seus projetos aparecem ou no título ou na posição de sujeito de seis a dez orações.

3. Alta: Foram considerados documentos que falam sobre o MAR com uma frequência alta aqueles em que o nome do museu ou de seus projetos aparecem no título do texto e aparecem na posição de sujeito de mais de dez orações.

O quadro a seguir ilustra a categorização feita em relação aos artigos e demais materiais escritos sobre o MAR, com a exceção das monografias, dissertações e teses incluídas na análise e que, por sua vez, são apresentadas no quadro seguinte. Em relação ao primeiro tipo de material, foram selecionados 20 trabalhos, que geraram um total de 31 páginas de fichas de revisão. A presente dissertação valeu-se ainda de uma monografia, duas dissertações e duas teses, que juntas deram origem a um total de 17 páginas de revisão. 
Quadro 10. Artigos acadêmicos e jornalísticos sobre o MAR

\begin{tabular}{|c|c|c|c|c|c|c|}
\hline Autor & Ano & Título & Tipo & Frequência & Eixo & Destaque \\
\hline Nobre & 2016 & $\begin{array}{l}\text { A city at play. Rio } \\
\text { de Janeiro on the } \\
\text { eve of the } 2016 \\
\text { Olympic and } \\
\text { Paralympic } \\
\text { Games }\end{array}$ & Artigo & Baixa & $\begin{array}{l}\text { Revitaliza- } \\
\text { ção }\end{array}$ & $\begin{array}{l}\text { Previsão sobre } \\
\text { o legado dos } \\
\text { Jogos Olímpicos } \\
\text { e Paralímpicos } \\
\text { no Rio de } \\
\text { Janeiro, cenário } \\
\text { político, reforma } \\
\text { urbana }\end{array}$ \\
\hline Jandir & 2017 & $\begin{array}{l}\text { Dentro }- \\
\text { Programa Sala de } \\
\text { Encontro: Museu } \\
\text { de Arte do Rio, } \\
\text { Rio de Janeiro - } \\
\text { Abertura: } 25 \text { de } \\
\text { março de } 2017\end{array}$ & Resenha & Alta & Exposição & $\begin{array}{l}\text { Modernidade, } \\
\text { democratização } \\
\text { da arte, Dentro, } \\
\text { Arte } \\
\text { sociedade no } \\
\text { Brasil, Lugares } \\
\text { de Delírio } \\
\end{array}$ \\
\hline $\begin{array}{l}\text { Leite \& } \\
\text { Olivei- } \\
\text { ra }\end{array}$ & 2015 & $\begin{array}{l}\text { Arte, educação e } \\
\text { poder: discursos } \\
\text { ocultos r nas } \\
\text { narrativas de } \\
\text { museus } \\
\text { brasileiros de arte }\end{array}$ & $\begin{array}{l}\text { Artigo } \\
\text { acadêmi- } \\
\text { co }\end{array}$ & Média & $\begin{array}{l}\text { Setor } \\
\text { educativo }\end{array}$ & $\begin{array}{l}\text { Visitas guiadas, } \\
\text { relações de } \\
\text { poder, } \\
\text { mediação, } \\
\text { Museu Nacional } \\
\text { de Belas Artes, } \\
\text { Museu de Arte } \\
\text { Contemporânea }\end{array}$ \\
\hline Vieira & 2019 & $\begin{array}{l}\text { Dja Guata Porã: o } \\
\text { rio indígena que } \\
\text { desaguou no } \\
\text { MAR }\end{array}$ & $\begin{array}{l}\text { Artigo } \\
\text { acadêmi- } \\
\text { co }\end{array}$ & Alta & Exposição & $\begin{array}{l}\text { Indígenas, } \\
\text { reinvenção, } \\
\text { ressurgência, } \\
\text { aldeias em } \\
\text { contexto urbano, } \\
\text { lugar de fala }\end{array}$ \\
\hline $\begin{array}{l}\text { Almei- } \\
\text { da \& } \\
\text { Ribeiro }\end{array}$ & 2013 & $\begin{array}{l}\text { Museu de Arte do } \\
\text { Rio - MAR: Uma } \\
\text { Abordagem do } \\
\text { Valor Patrimonial }\end{array}$ & $\begin{array}{l}\text { Artigo } \\
\text { acadêmi- } \\
\text { co }\end{array}$ & Alta & $\begin{array}{l}\text { Revitaliza- } \\
\text { ção }\end{array}$ & $\begin{array}{l}\text { Reforma } \\
\text { urbana, } \\
\text { patrimônio, } \\
\text { democratização }\end{array}$ \\
\hline $\begin{array}{l}\text { Mu- } \\
\text { nhoz et } \\
\text { al. }\end{array}$ & 2016 & $\begin{array}{l}\text { Notas sobre uma } \\
\text { residência } \\
\text { pedagógica no } \\
\text { Museu de Arte do } \\
\text { Rio }\end{array}$ & $\begin{array}{l}\text { Artigo } \\
\text { acadêmi- } \\
\text { co }\end{array}$ & Alta & $\begin{array}{l}\text { Setor } \\
\text { educativo }\end{array}$ & $\begin{array}{l}\text { Educação, } \\
\text { currículo, } \\
\text { experimentação }\end{array}$ \\
\hline $\begin{array}{l}\text { Dacos- } \\
\text { ta }\end{array}$ & 2018 & $\begin{array}{l}\text { O Rio do Samba - } \\
\text { Resistência } \\
\text { Reinvenção }\end{array}$ & Artigo & Alta & Exposição & $\begin{array}{l}\text { Momentos da } \\
\text { exposição, } \\
\text { identidade } \\
\text { carioca, música }\end{array}$ \\
\hline $\begin{array}{l}\text { Benites } \\
\& \\
\text { Lafuen } \\
\text {-te }\end{array}$ & 2018 & $\begin{array}{l}\text { A Way of Working } \\
\text { Together. On Dja } \\
\text { Guata Porã: Rio } \\
\text { de } \quad \text { Janeiro } \\
\text { indígena }\end{array}$ & $\begin{array}{l}\text { Artigo } \\
\text { acadêmi- } \\
\text { co }\end{array}$ & Alta & Exposição & $\begin{array}{lr}\text { Tradução dos } \\
\text { conceitos entre } \\
\text { as culturas; } \\
\text { objetivos da } \\
\text { exposição, } \\
\text { alguns } \\
\text { momentos da } \\
\text { exposição }\end{array}$ \\
\hline Baker & 2018 & $\begin{array}{lr}\text { Curadoria } & \\
\text { participativa: } & \text { O } \\
\text { caso } & \text { da } \\
\text { exposição } & \text { Dja } \\
\text { Guata Porã } & \text { no } \\
\text { Museu de Arte do } \\
\text { Rio (MAR) } \\
\end{array}$ & $\begin{array}{l}\text { Texto em } \\
\text { anais }\end{array}$ & Alta & Exposição & $\begin{array}{l}\text { Concepção da } \\
\text { exposição, } \\
\text { lógica outra, } \\
\text { indígenas, } \\
\text { quebra } \\
\text { paradigma }\end{array}$ \\
\hline $\begin{array}{l}\text { Gue- } \\
\text { des et } \\
\text { al. }\end{array}$ & 2017 & $\begin{array}{l}\text { Dja Guata Porã: } \\
\text { Construções em } \\
\text { diálogo }\end{array}$ & $\begin{array}{l}\text { Texto em } \\
\text { anais }\end{array}$ & Alta & Exposição & $\begin{array}{l}\text { Interculturalida- } \\
\text { de, constituição } \\
\text { da exposição, } \\
\text { desafios e } \\
\text { potencialidades } \\
\text { da exposição }\end{array}$ \\
\hline
\end{tabular}




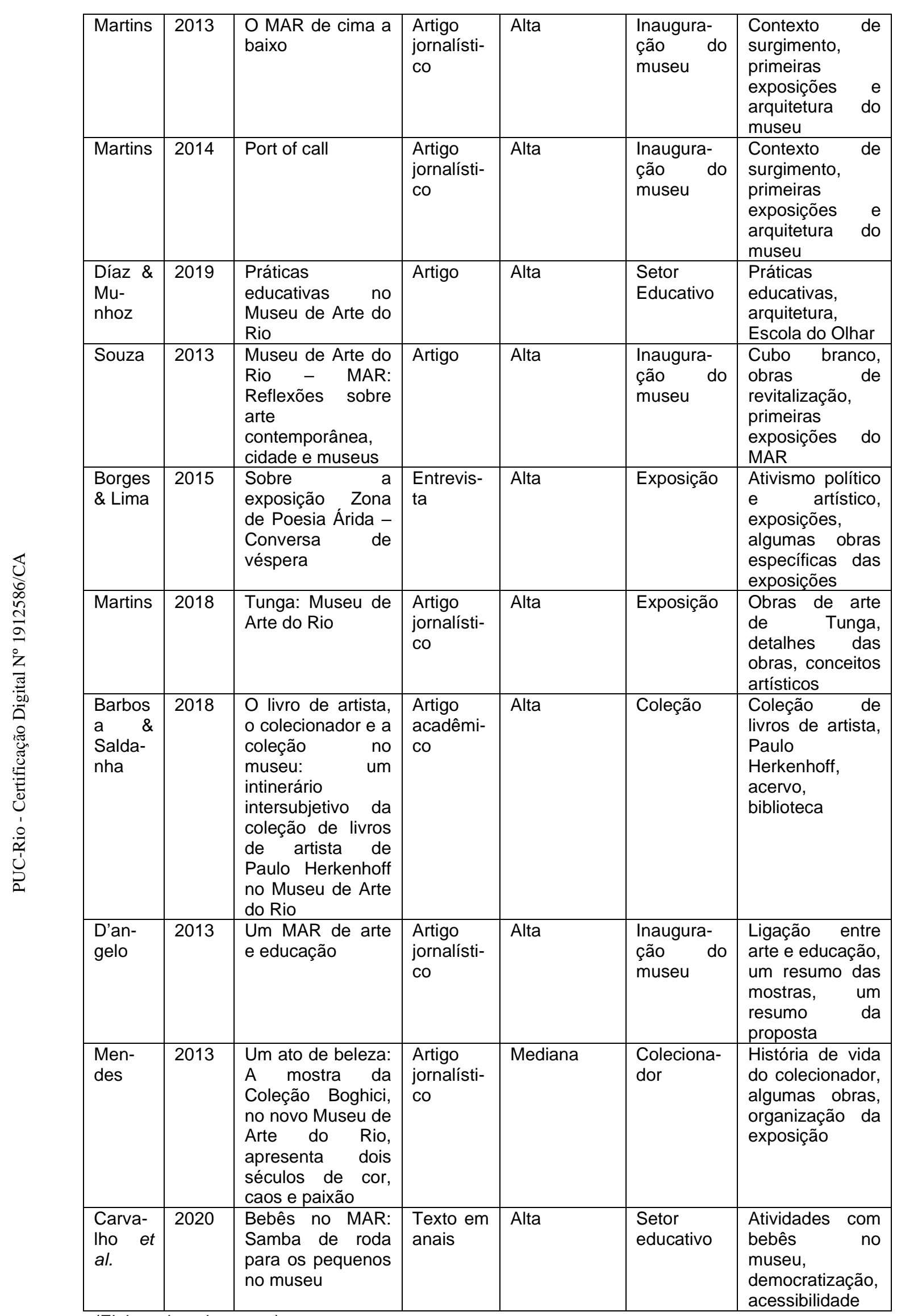

(Elaborado pela autora) 
Quadro 11: Teses, dissertações e monografias

\begin{tabular}{|c|c|c|c|c|c|c|}
\hline Autor & Ano & Título & Nível & Área & $\begin{array}{l}\text { MAR } \\
\text { como } \\
\text { tema } \\
\text { principal? }\end{array}$ & Destaque \\
\hline Motta & 2018 & $\begin{array}{lr}\text { Discursos } & \text { de } \\
\text { Contrainformação: } \\
\text { Coletivos } \\
\text { artistas de } \\
\text { curadores-autores } \\
\text { no Brasil (2000- } \\
2015)\end{array}$ & Tese & Artes Visuais & Sim & $\begin{array}{l}\text { Contexto } \\
\text { político, } \\
\text { surgimento de } \\
\text { novas } \\
\text { práticas } \\
\text { artísticas e } \\
\text { curatoriais }\end{array}$ \\
\hline Lopes & 2019 & $\begin{array}{l}\text { Outras Formas de } \\
\text { Conhecer } \\
\text { Mundo: Educação } \\
\text { Infantil em Museus } \\
\text { de Arte, Ciência e } \\
\text { História }\end{array}$ & Tese & Educação & Não & $\begin{array}{l}\text { Visitas } \\
\text { educativas } \\
\text { com turmas } \\
\text { de educação } \\
\text { infantil }\end{array}$ \\
\hline Boing & 2016 & $\begin{array}{l}\text { A educação } \\
\text { praticada no/com } \\
\text { o MAR: o que nos } \\
\text { dizem gestos e } \\
\text { narrativas dos } \\
\text { educadores do } \\
\text { museu? }\end{array}$ & Dissertação & Educação & Sim & $\begin{array}{l}\text { Trabalho dos } \\
\text { educadores } \\
\text { do museu }\end{array}$ \\
\hline Silva & 2018 & $\begin{array}{l}\text { \#museumselfie: } \\
\text { sociabilidades } \\
\text { mediadas por } \\
\text { imagens } \\
\text { conectadas no } \\
\text { Instagram }\end{array}$ & Dissertação & $\begin{array}{l}\text { Comunicação } \\
\text { social }\end{array}$ & Não & $\begin{array}{l}\text { Selfies tiradas } \\
\text { em museus }\end{array}$ \\
\hline Ramos & 2014 & $\begin{array}{l}\text { Mergulho no MAR: } \\
\text { Um estudo- } \\
\text { reportagem sobre } \\
\text { o Museu de Arte } \\
\text { do Rio - A } \\
\text { relevância } \\
\text { sociocultural de } \\
\text { um museu } \\
\text { temático da cidade } \\
\text { do Rio de Janeiro }\end{array}$ & Monografia & $\begin{array}{l}\text { Comunicação } \\
\text { social } \\
\text { Jornalismo }\end{array}$ & Sim & $\begin{array}{l}\text { Inauguração } \\
\text { e projeto do } \\
\text { museu }\end{array}$ \\
\hline
\end{tabular}

(Elaborado pela autora) 


\section{4}

\section{As práticas estético-político-pedagógicas do MAR}

Em 2011, nas vésperas da cidade do Rio de Janeiro receber dois megaeventos de projeção mundial, a Copa do Mundo de 2014 e os Jogos Olímpicos de 2016, teve início o Projeto Porto Maravilha. Trata-se de um projeto de revitalização da zona portuária do município, considerado então a maior parceria público-privada (PPP) da América Latina. O empreendimento causou a remoção de cerca de 67 mil pessoas que moravam na área. Na Praça Mauá, como elementos-chave do Projeto Porto Maravilha, dois espaços museais foram construídos: o Museu do Amanhã e o Museu de Arte do Rio (MAR) (GONÇALVES, 2019).

Os dois museus se destacam como contraditórios. O Museu do Amanhã é um museu de ciências dirigido às questões ambientais e ao futuro do planeta, amparando suas experiências em recursos tecnológicos interativos. A temática, apesar de ser pertinente, não é compatível com o fato de o Rio ser uma cidade que não recicla nem $3 \%$ do lixo produzido e em que o índice de tratamento de esgoto chega a apenas 34\% (CAVALCANTI, 2016). No entanto, o MAR configurou-se como um dos principais alvos de críticas e polêmicas desde sua inauguração, que se deu às pressas, em 2013. O MAR, o primeiro elemento do Projeto a ser entregue à população, nasce dentro do contexto em que a cidade do Rio de Janeiro se firma enquanto uma cidade global, um modelo hegemônico de gestão urbana enraizado no processo de globalização da economia.

De acordo com De Lira Bottura (2014), esse tipo de gestão toma como referencial a eficácia e a eficiência dentro da competitividade mundial, o que termina por impulsionar a fragmentação territorial e a participação do capital privado, principalmente através do modelo PPP, se valendo também do marketing urbano. Trata-se, assim, de um processo que reorganiza e reimagina a cidade para sua "venda". Há, portanto, uma movimentação dentro do campo econômico e administrativo, que envolve os interesses do capital privado, mas também dentro do campo simbólico, que demanda um trabalho de reelaboração da imagem da cidade, em uma associação à cultura. Dentro deste contexto, conforme demonstra a autora, os megaeventos se constituem enquanto oportunidades para o marketing das cidades, que se preparam com projetos de infraestrutura - ligados de alguma 
forma a projetos culturais - feitos em um tempo reduzido para atrair investimentos.

A concepção do Rio de Janeiro enquanto cidade global é essencial para a compreensão tanto do contexto de surgimento do MAR como da contradição que ele próprio anuncia ao abrir as portas, em 2013, trazendo, entre suas quatro exposições inaugurais, $O$ Abrigo e o Terreno $^{41}$, que dava início a uma série de exposições chamada Arte e sociedade no Brasil. A mostra trazia obras de diversos artistas contemporâneos e de coletivos de artistas em torno do tema habitação e moradia e denunciava o fato de que os projetos de revitalização das cidades, como aquele que deu origem ao MAR e reestruturou a Praça Mauá, causam a desterritorialização da parte vulnerável da população.

Surgido da desterritorialização, o MAR se destaca por buscar se territorializar. Abarcando uma gama diversa de temáticas em suas exposições, o museu, de maneira geral, busca relacioná-las à história e às culturas da cidade do Rio, procurando fazer emergir as questões dos povos subalternizados e seu papel na construção do que se reconhece atualmente como a cultura carioca, enquanto uma parte significativa da cultura brasileira. Exemplo disto é o fato de, apenas no ano de 2019, terem passado pelo MAR as exposições A Pequena África e o MAR de Tia Lúcia, O Rio do Samba e $O$ Rio dos Navegantes ${ }^{42}$. As três exposições contam, sob diferentes ângulos, a história do Rio de Janeiro, com um foco especial na região portuária, onde está o museu, trazendo como protagonistas personagens africanos ou afro-brasileiros, assim como de outros grupos historicamente subalternizados e invisibilizados, que, em sua maioria, passaram ou até mesmo viveram pelo território em que está o museu. Tais mostras, como grande parte das exposições do MAR, construíram uma narrativa que evidencia uma ruptura com regimes de representação tradicionais dos museus e que segue uma linha epistêmica em sentido contrário à lógica colonial/ moderna/ eurocêntrica.

\footnotetext{
${ }^{41}$ O Abrigo e o Terreno (03/2013 - 07/2013), curadoria de Paulo Herkenhoff e Clarissa Diniz.

${ }^{42}$ A Pequena África e o MAR de Tia Lúcia (11/2018 - 03/2019), curadoria de Izabela Pucu e Bruna Camargos.

O Rio do Samba: resistência e reinvenção (04/2018 - 04/2019), curadoria de Nei Lopes, Evandro Salles, Clarissa Diniz e Marcelo Campos.

O Rio dos Navegantes (05/2019 - 05/2020), curadoria de Evandro Salles, Fernanda Terra, Marcelo Campos, Pollyana Quintela e consultoria de Francisco Carlos Teixeira.
} 
A contextualização do Rio de Janeiro como cidade global é ainda necessária para situar a análise que se pretende fazer dentro da perspectiva decolonial, que interpreta a globalização como o ponto culminante do projeto capitalista neoliberal que teve seu início nos processos de conquista.

Em relação às discussões entre os organizadores para a concepção de um novo museu, Ramos (2014) destaca que estas se deram em torno de proporcionar ao Rio de Janeiro um museu que a cidade ainda não tinha e que fosse necessário a ela. Enfatiza também o papel de Paulo Herkenhoff ${ }^{43}$, primeiro diretor cultural do MAR e curador-chefe de muitas exposições da instituição, nas mudanças feitas no plano inicial do museu, que o tornaram mais inovador e democrático. Menciona ainda os aspectos arquitetônicos da instituição pela sua beleza, referindo-se também à preocupação com a sustentabilidade e com a acessibilidade que permeou o projeto de construção do museu, além de destacar os diferentes usos dos espaços, que fogem do ideal de silêncio e elitismo que marca a tradição desse tipo de instituição.

Ramos (2014) volta sua análise para a questão da representatividade do MAR enquanto um museu da cidade do Rio de Janeiro, destacando o papel desse tipo de instituição na preservação das memórias. Afirma também que os museus podem tanto se dedicar a este papel no sentido de manter determinadas relações de poder, selecionando memórias que exaltam certas populações e excluindo outras, por exemplo, ou ainda reinventando tais relações, trazendo ao debate questões do passado que costumam ser silenciadas e atribuindo valor a elementos culturais antes desvalorizados, caminho este que seria seguido pelo MAR.

A autora realça ainda como o propósito democratizante do MAR se expressa em seu ambicioso projeto educativo, configurando-se como um museu que procura ser compreendido e apreciado por todos. Nesse sentido, a instituição oferece, na Escola do Olhar, oficinas, cursos, visitas educativas, entre outras atividades, para pessoas de todas as idades, além de buscar manter um contato bem próximo com as escolas da rede pública de ensino e com os moradores da região.

\footnotetext{
${ }^{43}$ Atualmente, Herkenhoff é responsável pela curadoria do acervo do MAR.
} 
Conforme ressalta Motta (2018), o MAR foi concebido sobre três eixos: (1) um museu de arte, (2) com uma dimensão pedagógica e (3) tendo a cidade do Rio como tema central.

Com o mergulho no material coletado, foi possível estabelecer os três pontos de observação do MAR, que se desenvolvem nos subcapítulos a seguir. No primeiro deles, é possível perceber seus aspectos mais polêmicos e até mesmo contraditórios. Assim, serão abordados o contexto de surgimento do museu, a questão da PPP e sua gestão por organização social (OS). A este respeito, a ideia de brechas decoloniais, proposta por Walsh (2016), servirá como um caminho para pensar como uma instituição que surge dentro de um modelo de gestão fundamentalmente neoliberal pode representar, ainda assim, um espaço de resistência e insurgência. A exposição $O$ Abrigo e o Terreno será aqui uma ilustração das questões abordadas. No segundo ponto de observação, é possível contemplar a Escola do Olhar e a educação praticada no MAR em um sentido mais restrito. Neste ínterim, será abordada também a questão da democratização do museu, dos públicos que o MAR recebe e de como eles se relacionam com o museu. Quanto a públicos específicos, devido à vinculação da presente dissertação ao Grupo de Estudo e Pesquisa em Educação Museu, Cultura e Infância (GEPEMCI), será abordado como a instituição recebe as crianças. Ainda com relação à educação, será discutida a interculturalidade crítica neste espaço. E a mostra Dja Guata Porã ${ }^{44}$ constituirá a elucidação dos tópicos levantados. Por fim, o foco recairá sobre o contexto mais recente do MAR, que compreende os anos de 2019, quando o museu quase fechou por problemas de financiamento, e de 2020, quando a instituição se manteve fechada durante quase todo o ano devido à pandemia de covid-19 no Brasil. Neste ponto, serão abordadas as saídas encontradas pelo museu para os desafios enfrentados. A exposição Casa Carioca $^{45}$ exemplificará as ações do MAR neste contexto. Como será possível notar, apesar do enfoque nestas três mostras, outras obras, exposições e até pequenos momentos vividos no museu serão convocados na narrativa, enquanto o que está sendo chamado de práticas estético-político-pedagógicas do MAR.

\footnotetext{
${ }^{44}$ Dja Guata Porã: Rio de Janeiro indígena (05/2017 - 03/2018), curadoria de Sandra Benites, José Ribamar Bessa Freire, Pablo Lafuente e Clarissa Diniz.

${ }^{45}$ Casa Carioca (09/2020 - 09/2021), curadoria de Marcelo Campos e Joice Berth.
} 


\section{1 \\ Surfando dentro da onda: O MAR, suas contradições e as brechas decoloniais - $O$ Abrigo e o Terreno}

Abracei o mar na lua cheia, abracei

Abracei o mar

(Calazans \& Gerônimo/ Maria Bethânia)

Em uma das salas da exposição $O$ Abrigo $e$ o Terreno, era possível encontrar postas lado a lado as obras Nas quebradas, de Hélio Oiticica (1979), e Mar revolto é coisa do passado, mar tranquilo é mar nunca navegado, de Ernesto Neto (2012-13).

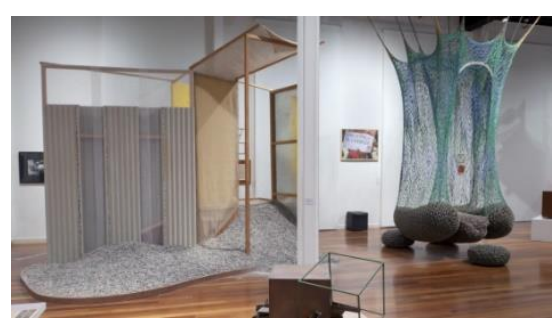

Figura 5: Vista da exposição $O$ Abrigo e o Terreno, com as obras de Oiticica e Ernesto Neto lado a lado. Foto: Rafael Adorján

Embora tenham em comum o fato de serem interativas, sendo ambas instalações artísticas de tipo espacial-imersivo, as experiências que suscitam são absolutamente contrárias.

A primeira, um penetrável, composto por pedras e telhas, traz a experiência de confusão, de uma casa em construção ou em demolição. Já a segunda, composta por puffs e uma espécie de rede de balanço suspensa por fios de crochê, traz a experiência de acolhimento, do útero da mãe, do colo da avó, do abrigo. O nome da obra é em celebração à inauguração do MAR e também um convite para encarar o Museu como esse abrigo, um mar tranquilo, que ainda não foi navegado e, por isso mesmo, apresenta certa plasticidade para se tornar qualquer coisa. (REBOUÇAS, 2020, p. 223).

O convite, que a princípio é feito pelo nome dado à obra, é repetido pelo artista, durante a sua participação na Conversa de Galeria (MAR, 2013, vídeo $1)^{46}$, organizada pela Escola do Olhar como uma das atividades que compunham

\footnotetext{
46 Para evitar uma quantidade numerosa de notas de rodapé, os vídeos (do canal do MAR no YouTube) citados são identificados no texto, a partir da ordem em que aparecem, como "vídeo 1", "vídeo 2" etc. e referenciados por completo ao final de cada subcapítulo, 4.1, 4.2 e 4.3. No caso do evento \#MARé, este foi identificado como "evento1", uma vez que se trabalhou com o relatório do próprio evento e não com o registro em vídeo.
} 
parte da mostra. No vídeo de registro, é possível ver Ernesto Neto, dentro da galeria, conversando sobre a sua obra com o público.

Ernesto Neto, que tem um fluxo de fala repleto de idas e vindas, que parece encantar o público, se apresenta como um escultor. A escultura, conforme discorre, é algo que, via de regra, tem que ficar em pé, lidando, assim, necessariamente com a gravidade. A arte, segundo ele, é algo que mistura algo de físico e de imaterial de modo a suscitar em nós sentimentos ou pensamentos. Nesse caso, é a gravidade que o faz pensar. Dois outros elementos que o mobilizaram na criação foram a sua fascinação com a elasticidade dos tecidos e o seu gosto de se apoiar nos lugares. Assim, surgiu a ideia de usar a gravidade de forma invertida - "ao invés de puxar para cima, ir de cima para baixo" -, fazendo esculturas que flutuassem. Estava desenvolvendo, na época dessas mobilizações, uma técnica de crochê a dedo.

Outro fator sobre o qual refletia e que influenciou suas obras foi a reação agressiva que o Estado tinha em relação aos camelôs, os vendedores ambulantes. O fascinava a maneira como eles conseguiam ocupar espaços utilizando as estruturas já existentes e recolher toda a mercadoria rapidamente em uma trouxinha, carregando-a para outro lugar. Pensou em fazer um tipo de obra que tivesse um "estado camelô", ou seja, que fosse transportada com facilidade, o que acarretava também em mais oportunidades de ser visto.

Em relação ao material de sua obra, Neto diz que queria um projeto que se parecesse com a carne, esculturas que se assemelhassem com a pele e, quanto ao processo de confecção, explica que o crochê estabelece uma relação direta da mente com a mão. Ambos os aspectos conferirem algo de orgânico às suas obras e ao seu processo de construção. Sobre a peça feita para o MAR, afirma que se baseou no "desejo de que o MAR nos leve para muitos lugares".

Heloísa Buarque de Hollanda, escritora e professora da Universidade Federal do Rio de Janeiro (UFRJ), no encontro \#MARé (MAR, 2020, evento 1), relatou sobre como descobriu no MAR esse abrigo para seu projeto da Universidade das Quebradas (UQ). A ideia da UQ era estabelecer uma relação de troca entre universidade e periferia, para que, a partir desse diálogo, surgisse algo novo. Segundo Hollanda, no lugar da adoção de uma distância antropológica, em que a academia iria examinar a periferia, e de uma visão salvacionista, de levar o conhecimento para as áreas pobres, a perspectiva era mais voltada a "salvar a 
universidade do que a favela". O projeto foi, a princípio, rejeitado pela Faculdade de Educação da UFRJ. Quando soube da notícia, Paulo Herkenhoff, então diretor cultural e curador-chefe do MAR, quis receber o projeto no museu. Posteriormente, o projeto tomou forma através de uma parceria entre o MAR e a Faculdade de Letras da UFRJ. Para Heloísa, a sua utopia combinou com a de Paulo e, por isso, a parceria deu certo.

Heloísa afirma que ainda tem a lembrança do exato momento em que Herkenhoff teve a ideia do nome "MAR". Relembra então que, em uma reunião, na qual era discutido qual seria o nome do novo museu, ele escreveu o nome "MAR" em um pedaço de papel e passou para ela, para, em seguida, explicar para os demais que por este nome seria conhecido o Museu de Arte do Rio. Por fim, Heloísa destacou a imprecisão do MAR, já anunciada desde o nome, em relação às suas idas e vindas.

Herkenhoff, na palestra Arte: História, Crítica e Curadoria (MAR, 2014, vídeo 2), aponta que o MAR vive "uma falsa dúvida" sobre ser um museu com uma escola ou uma escola com um museu. Em resposta, afirma categoricamente: "Isso é um museu". Para responder o que é um museu, se recorda de uma noite em Buenos Aires, com Aracy Amaral ${ }^{47}$, no congresso do Conselho Internacional de Museus (ICOM), quando tinha recentemente assumido a curadoria do Museu de Arte Moderna (MAM). Ela falou sobre o que deveria ser um museu e ele levou essa definição consigo: "Um museu deve colecionar, preservar, pesquisar, expor, comunicar e educar". Na percepção de Herkenhoff, era necessário ao Rio de Janeiro um museu que colecionasse, uma vez que muitas coleções estavam saindo da cidade.

Segundo Herkenhoff, o então prefeito Eduardo Paes desejava que a praça que conectava o porto ao centro da cidade, a Praça Mauá, tivesse um museu de arte, que veio a ser o MAR, e um museu de ciências, o Museu do Amanhã. De acordo com o curador, desde o projeto do MAM, não havia ocorrido um grande projeto de arquitetura no Rio de Janeiro. Afirma ainda que esse novo momento marca um renascimento do conceito de arquitetura como arte, dentro do qual o próprio edifício constitui o primeiro objeto artístico do museu.

\footnotetext{
${ }^{47}$ Aracy Amaral é crítica, curadora de arte e professora da Universidade de São Paulo (USP).
} 
Mencionando a resistência de alguns setores da população e partidos políticos à construção do novo museu, Herkenhoff assinala algumas polêmicas. Uma delas dizia respeito à barreira de vidro colocada no térreo, que fechou uma área que antes era aberta. Segundo as críticas, essa seria uma prova da elitização do novo espaço. Martins (2013), por exemplo, afirma que, apesar de o espaço dos pilotis ter sido liberado visualmente, a barreira de vidro segrega o museu, e remete à frente dos condomínios da área mais privilegiada da cidade. Entretanto, conforme a explicação de Herkenhoff (MAR, 2014, vídeo 2), o museu já tinha como projeto uma ênfase no trabalho com o ensino fundamental e, portanto, deveria se preparar para receber crianças. Assim, a barreira foi colocada para protegê-las. De fato, é comum ver crianças, em visitas escolares ou espontâneas, circulando pelo térreo do museu correndo, lanchando e até mesmo interagindo com algumas obras que, por vezes, são dispostas no espaço.

Outra questão polêmica que Herkenhoff destaca é a adoção do regime de OS. O MAR foi o primeiro equipamento cultural do Rio a adotar o modelo, que se baseia, essencialmente, em um contrato firmado entre o Estado e uma OS. O curador relata que dirigiu o Museu Nacional de Belas Artes (MNBA), uma instituição com gestão e financiamento públicos, e não aceitaria entrar para o MAR se não fosse com o modelo de OS, porque proporciona muito mais eficiência. Se refere ao período em que trabalhou no MNBA como uma época desastrosa em relação à gestão pública. Cita como um exemplo da falta de eficiência e da burocracia nesse tipo de gestão o fato de que, para comprar uma caneta, era preciso fazer o pedido em Brasília. Em comparação, no MAR, na inauguração, os vidros foram quebrados em um protesto. Sem nenhuma nota na imprensa ou qualquer alarde, o conselho da OS se reuniu com o corpo do museu e, no dia seguinte, recolocaram os vidros.

Herkenhoff afirma que, ainda assim, o museu é público, uma vez que recebe recursos diretamente da Prefeitura, o que significa que a população paga pela instituição e, por isso, é preciso que receba um retorno. Era, portanto, necessário pensar no oferecimento de algo que a cidade ainda não tivesse. Sua ideia era a de um museu para a cidade, mas que fosse também um museu local. Além disso, queria criar um museu suburbano, que não fosse para "quem já sabe de tudo", e, portanto, seria necessário que fosse uma instituição que se relacionasse muito com a audiência. Nesse contexto, o programa educativo e a integração entre o museu e 
as escolas da rede pública emergiram como uma forma de lidar com a dimensão pública da instituição.

Em sua monografia, Ramos (2014) realiza uma entrevista com o museólogo Mário Chagas, que aponta que a proposta de Herkenhoff de um museu suburbano é, em certa medida, questionável. A própria localização do museu, no centro da cidade, e as opções de transporte público para chegar até a instituição já o impedem de ser fundamentalmente suburbano. Há de se destacar, contudo, que há uma quantidade considerável de favelas no entorno do museu, como o Morro da Providência, e a própria área ao redor da Praça Mauá é mais economicamente desprivilegiada em comparação com outras áreas do centro.

Julia Baker, então assistente curatorial do MAR, em entrevista a Ramos (2014, p. 56), sinaliza que, ao falar em um museu para o subúrbio, Herkenhoff quer se referir a uma instituição voltada a uma audiência que não fosse aquela já "entendida de arte".

A respeito da constituição da coleção, Herkenhoff (MAR, 2014, vídeo 2) afirma que o processo é muito aberto. Alguns colecionadores ou artistas doam obras esparsas, e há ainda os fundos, que são pessoas e instituições que decidem doar uma quantidade maior de peças ao museu, seguindo um ritmo próprio. Segundo ele, o museu tinha então, em 2014, mais de 60 fundos. Há ainda a constituição de núcleos significativos, que consiste em uma organização do acervo a partir de determinados temas de interesse.

Quanto ao acervo geral do MAR, Barbosa \& Saldanha (2018) ressaltam que ele se divide em três coleções: museológica, composta por pinturas, esculturas etc.; arquivística, formada por fotografias, cartões postais etc.; e bibliográfica, da qual fazem parte livros, periódicos etc. Cada coleção, segundo os autores, tem seu armazenamento em um lugar determinado. Na reserva técnica, no Palacete Dom João VI, fica a coleção museológica sob os cuidados da equipe de museologia. $\mathrm{Na}$ biblioteca, localizada dentro da Escola do Olhar, encontram-se as coleções arquivística e bibliográfica, sob a responsabilidade da bibliotecária. Os autores destacam também que o acervo da biblioteca pode ser de dois tipos: de acesso livre ou restrito. Todo o material pode ser consultado pelo público externo. No entanto, aquele de acesso restrito requer agendamento prévio, enquanto o de livre acesso pode ser encontrado no salão de leitura, aberto aos visitantes de forma gratuita. 
Segundo Barbosa \& Saldanha (2018), quando o MAR inaugurou, a estrutura de guarda de acervo ainda não estava finalizada e a equipe para a biblioteca não tinha sido contratada. Foi decidido que o acervo a ser formado, além de precisar ser desenvolvido preferencialmente por doações, deveria se voltar à arte, à cultura visual, ao Rio de Janeiro, à história da escravidão e à cultura afro-brasileira.

Os autores enfatizam que a coleção de livros de $\operatorname{artista}^{48}$ do MAR constitui uma das maiores coleções institucionais de obras desse gênero no Brasil. O início dessa coleção se deu, no fim de 2013, a partir da doação do próprio Herkenhoff de cerca de 1.200 livros, entre os quais se destacam os livros de artista de diversas tipologias e nacionalidades.

Em relação ao programa curatorial, Clarissa Diniz, na palestra Arte: História, Crítica e Curadoria (MAR, 2014, vídeo 3), explica que ele se organiza em 5 grandes núcleos: 1) História do Rio de Janeiro, que ocupa o terceiro andar do pavilhão de exposições - o antigo palacete - e que trabalha traçando diferentes olhares sobre a história da cidade. Do Valongo à Favela e Rio de Imagens ${ }^{49}$ são exemplos de exposições deste núcleo; 2) Revisão da história da arte no Brasil, que retoma movimentos artísticos pouco abordados ou a produção artística de lugares do Brasil que foram negligenciados pela historiografia tradicional, como o Norte e o Nordeste. Pernambuco Experimental e Pororoca ${ }^{50}$ são exemplos de mostras deste núcleo; 3) Coleção, um núcleo que diz respeito ao fato de que cada exposição precisa ser testemunha e, ao mesmo tempo, participante da formação da coleção, de modo que parte das obras expostas são incorporadas ao acervo; 4) Exposições individuais, que visa incluir artistas novos ou pouco conhecidos no eixo Rio-São Paulo. Exemplos de exposições desse tipo são Turvações

\footnotetext{
${ }^{48}$ Barbosa \& Saldanha (2018) definem o livro de artista como o tipo de obra que, se valendo de linguagem verbal e não verbal, do uso de imagens, texturas e formas, se estabelece como um híbrido entre o texto informativo e a obra de arte. Trata-se, segundo os autores, de um objeto no qual busca-se condicionar uma dimensão informacional e outra estética, isto é, um design que tanto proporcione uma experiência artística quanto diga algo a respeito das posições estéticopolíticas do autor.

${ }^{49}$ Do Valongo à Favela: imaginário e periferia (05/2014 - 05/2015), curadoria de Rafael Cardoso e Clarissa Diniz.

Rio de Imagens: uma paisagem em construção (03/2013 - 07/2013), curadoria de Carlos Martins e Rafael Cardoso.

${ }^{50}$ Pernambuco Experimental (12/2013 - 03/2014), curadoria de Paulo Herkenhoff e Clarissa Diniz.

Pororoca - A Amazônia no MAR (09/2014 - 11/2014), curadoria de Paulo Herkenhoff.
} 
Estratigráficas, de Yuri Firmeza, e Eu como Você ${ }^{51}$, do Grupo EmpreZa; 5) Exposições transversais, que partem de alguma questão em voga no momento e a abordam a partir de perspectivas múltiplas. Exemplos de mostras desse tipo são Josephine Baker e Le Corbusier ${ }^{52}$ e todas as exposições do programa Arte e Sociedade no Brasil ${ }^{53}$.

A moradia, conforme destaca Diniz, era o tema em voga na época de abertura do MAR, devido ao projeto Porto Maravilha, que previa a remoção de um número grande de pessoas. Partindo desta questão, foi criada a exposição $O$ Abrigo e o Terreno, como a primeira parte do programa Arte e sociedade no Brasil.

De acordo com Diniz, a mostra $O$ Abrigo e o Terreno gerou diversos tipos de polêmica. Uma delas foi em relação ao projeto que seria feito entre o coletivo carioca Opavivará! e a Escola Pimpolho, a escola de samba mirim da Grande Rio, cujo barracão foi removido como parte do projeto de reforma da cidade. $\mathrm{O}$ desfile foi impedido devido ao fechamento pela polícia de parte do perímetro perto do museu, em razão da presença da então presidenta Dilma Rousseff, na inauguração da instituição. Segundo Diniz, em frente ao museu, estava acontecendo um protesto contra as remoções e contra o fechamento dos teatros, que tiveram seus alvarás revistos após o incêndio na boate Kiss, no Rio Grande do Sul ${ }^{54}$. Não haveria como a polícia diferenciar o que seria parte do projeto do Opavivará! e o que seria parte do protesto.

Para Martins (2013), o impedimento da ação do Opavivará! é um exemplo dos desafios que o MAR enfrenta devido ao seu formato híbrido, entre o público e o privado, e que diminui o seu potencial em trazer contribuições valiosas para o panorama artístico carioca. O autor relata que, após o acontecimento, o MAR

${ }^{51}$ Yuri Firmeza: Turvações Estratigráficas (09/2013 - 12/2013), curadoria de Paulo Herkenhoff, Clarissa Diniz e Yuri Firmeza.

Eu como Você (05/2014 - 07/2014), curadoria coletiva MAR e Grupo EmpreZa.

52 Josephine Baker e Le Corbusier no Rio - Um caso Transatlântico (04/2014 - 08/2014), curadoria de Inti Guerrero e Carlos Maria Romero.

${ }^{53} \mathrm{O}$ programa Arte e sociedade no Brasil reúne exposições que discutam através da arte temas de interesse e relevância para a sociedade brasileira. Além de O Abrigo e o Terreno, que discute a moradia, fazem parte do programa mostras como Há escolas que são gaiolas e há escolas que são asas, sobre a educação, e Lugares de Delírio, sobre a saúde mental.

${ }^{54}$ Em janeiro de 2013, na boate Kiss, no município de Santa Maria, Rio Grande do Sul, houve um incêndio no qual mais de 200 pessoas morreram. A tragédia repercutiu por todo o Brasil. No Rio de Janeiro, aconteceu uma vistoria massiva em casas de reunião de público, como boates, teatros e restaurantes. Muitos espaços foram fechados por não possuírem a estrutura mínima de segurança contra incêndios. 
divulgou uma nota de esclarecimento na qual não expunha nenhum tipo de posicionamento crítico em relação à decisão da Prefeitura em impedir o desfile.

Outra questão polêmica foi a instalação Poética do Dissenso, realizada pelos coletivos de artistas Frente 3 de Fevereiro, Nova Pasta e outros, que fazia uma documentação em torno da Ocupação Prestes Maia $^{55}$, em São Paulo, e que discutia, além da questão da moradia, o envolvimento da arte com os movimentos sociais. A respeito da instalação, Diniz (MAR, 2014, vídeo 3) enumera uma série de discussões que foram suscitadas. Uma delas seria sobre a própria produção artística. Muitos jornalistas, críticos de arte, artistas e visitantes em geral argumentavam que o que estava exposto pertencia ao âmbito do ativismo e não da arte. Houve também quem alegasse que os artistas que participaram da exposição "se venderam ao sistema". Por vaidade, queriam ter sua produção inserida no museu e, assim, serem validados institucionalmente, mesmo que isso significasse colocar essa produção dentro de uma instituição criada como parte do mesmo projeto de gentrificação contra qual eles se colocavam ao participar das ocupações, e que a própria produção criticava. Dentro dos próprios coletivos que participaram na Ocupação Prestes Maia, houve quem se recusou a participar da exposição. Neste ínterim, foi criada ainda uma polarização entre Rio e São Paulo.

Fabiane Borges, uma das participantes dos coletivos paulistanos que criaram a Poética do Dissenso, no debate de encerramento da exposição (MAR, 2013, vídeo 4), relata que, quando o MAR convidou os artistas do Prestes Maia para participar da mostra, os mesmos já apontaram o paradoxo em ter protestado contra a gentrificação em São Paulo e depois expor em um museu construído como elemento-chave de um projeto de gentrificação no estado vizinho. Por isso, houve oposição de grande parte do grupo. Os que aceitaram o convite tentaram fazer contato com pessoas do Rio de Janeiro que produziram material, como vídeos ou fotos, que retratassem a gentrificação nessa cidade, mas também muitos, quando souberam que o destino do material seria uma exposição no MAR, se opuseram.

\footnotetext{
${ }^{55}$ Prestes Maia é o nome pelo qual é conhecido um edifício abandonado em uma rua da cidade de São Paulo que leva esse nome. O prédio, que já abrigou uma fábrica têxtil, se tornou residência para mais de 400 famílias que "ocupam" o edifício, no sentido de sua situação habitacional não ser regularizada pelo poder público. Entre os anos de 2002 e 2007, ocorreram muitas tentativas de despejo. Muitos coletivos de artistas atuaram no local, promovendo eventos e ações que chamavam a atenção da mídia e acabavam fazendo com que o poder público recuasse em suas investidas de desocupação forçada. Em 2007, houve uma desocupação negociada. Mas, pouco tempo depois, o edifício foi ocupado novamente.
} 
Ainda quanto ao programa curatorial do MAR, Diniz (MAR, 2014, vídeo 3) declara que este busca realizar um desdobramento de uma mesma temática em diversas exposições, não em um sentido de evolução, mas sim como o acréscimo de camadas ou a adoção de outras perspectivas para observar um mesmo tema. Nesse contexto, o tema da moradia foi retomado, ainda no primeiro ano do museu, pela exposição Turvações Estratigráficas, de Yuri Firmeza.

Ao longo das obras na região portuária, foram realizadas diversas escavações, como a que redescobriu o Cais do Valongo ${ }^{56}$, em 2011. As escavações resgataram a história dos africanos trazidos à força para o Brasil para serem escravizados. Na área do MAR, foram encontrados elementos como tijolos, canos, madeira, objetos pessoais, entre outros vestígios oriundos do aterramento dessa região com a derrubada do Morro do Castelo, no começo do século passado. $\mathrm{O}$ artista expôs o material arqueológico encontrado nas escavações da área do MAR. A demolição do Castelo constituiu um outro caso de desterritorialização da população negra e de racismo institucionalizado, uma vez que esta representava a maioria de sua população ${ }^{57}$. O movimento de derrubada e de remoção da população se repetia então com um projeto recente de remoção de aproximadamente 3 mil casas no Morro da Providência, próximo ao MAR. Firmeza coletou para a mostra parte dos destroços das casas que já haviam sido derrubadas. Segundo Diniz, a exposição fazia um diálogo entre esses dois momentos da história da cidade, além de questionar o que pode ser considerado material arqueológico e o que é lixo. Na mostra, foram exibidos também vídeos que Firmeza realizou com a ajuda de sua avó, que sofre de Alzheimer. Ele a acompanhou filmando seu dia a dia, privilegiando situações em que ela repetia ações depois de esquecer que já as tinha feito, como tomar café da manhã duas vezes seguidas.

\footnotetext{
${ }^{56}$ O Cais do Valongo, hoje um sítio arqueológico, foi, no século XIX, um local de desembarque e comércio de africanos escravizados.

${ }^{57}$ Essa informação é dada por Diniz no vídeo, mas é retomada pela arquiteta Thainá de Paula no curso Arte e pensamento anticoloniais. Segundo ela, as transformações nas cidades têm como ponto de partida as estruturas de poder. Assim, o Morro do Castelo não era apenas "um morro, um acidente geográfico, mas um território negro, que foi demolido por escolha de apagamento, de destruição e de racismo". De acordo com a arquiteta, o projeto de demolição compunha parte de um genocídio simbólico.

(MUSEU DE ARTE DO RIO. Curso Arte, ação e pensamento anticoloniais - Estamira: corpos que pesam, vidas que importam. 10 out. 2019. (2h41m54s). Disponível em: https://youtu.be/147NLCARm1M. Acesso em: 01 fev. 2020).
} 
Além dos vídeos de sua avó, Firmeza utilizou vídeos institucionais e propagandas governamentais associados aos megaeventos no Rio e ao Porto Maravilha e uma sequência de slides com imagens de elefantes.

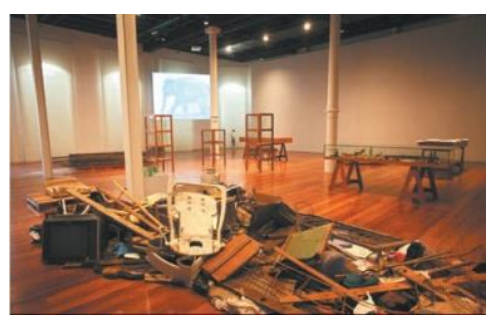

Figura 6: Vista da exposição Turvações Estratigráficas.

Foto: Bruna Prado.

Conforme analisa Motta (2018), a organização espacial dos diferentes grupos de elementos - os escombros, embaixo, e as telas com as imagens, em cima - criava dois planos, um material e outro, imagético. Esses dois planos se cruzavam, remetendo a uma crítica tanto aos processos históricos que se repetem, em uma sociedade que não tem memória, quanto às próprias perdas materiais e afetivas das pessoas prejudicadas pelas demolições. Por outro lado, os vídeos institucionais aludiam ao processo de modernização que se impõe "pelo alto" e que arrasa o que estiver pelo caminho.

O autor sinaliza que, além do senso histórico, em uma perspectiva crítica que coloca em evidência a ligação da construção do próprio museu e os processos de gentrificação e, assim, também de perda de memória, a exposição apresentava ainda como inovação a obra comissionada, uma produção artística que funcionava por encomenda e cujos procedimentos mesclavam-se com os da prática curatorial.

Diniz (MAR, 2014, vídeo 3) afirma que as obras e exposições comissionadas são um encontro entre algo que o museu já quer mostrar e que o artista acredita que combina com a sua poética e que já é uma de suas temáticas de interesse.

Conforme destaca Motta (2018, p. 235), O Abrigo e o Terreno e Turvações Estratigráficas são exemplos de mostras que tocaram em questões como "noções de território, de inscrição periférica, de identidade nacional e de ocupação do espaço urbano" e, assim, realizaram uma problematização da própria instituição. 


\subsection{1}

\section{Um mergulho no MAR}

Ramos (2014) destaca o momento de sua pesquisa, que coincidia com o período inaugural do MAR, como uma época em que os olhares do mundo se voltavam ao Rio de Janeiro, cidade selecionada para sediar muitos eventos de importância mundial. Ressalta ainda que o Rio é, por vezes, percebido internacionalmente como o exemplo de brasilidade, de maneira que a cidade, apesar de não ser a capital, constitui de forma recorrente a imagem do Brasil no exterior.

A autora aponta o cosmopolitismo da capital fluminense como um elemento que constitui ao mesmo tempo um desafio e uma potencialidade para um museu que planeja ser "do Rio". O desafio consiste em como a instituição pode se fazer representativa de "mais de seis milhões de pessoas que tem em comum apenas a cidade em que vivem" (RAMOS, 2014, p. 2). A potencialidade está na abertura para ir além das fronteiras e trazer exposições que tematizam outras áreas do país, como Pernambuco Experimental.

Segundo Ramos (2014), o MAR foi inaugurado no dia primeiro de março de 2013, data de comemoração do aniversário da cidade do Rio de Janeiro. Até então, de acordo com a autora, apesar de o município possuir muitos espaços museais, a Prefeitura do Rio não dispunha de um museu próprio ou de um espaço adequado para preservar e expor a memória e a história da cidade. Conforme já sinalizado, o MAR constituiu parte do projeto Porto Maravilha, foi construído através de uma PPP, recebe o patrocínio de grandes empresas e é gerido por uma OS, o Instituto Odeon.

Em uma análise do momento inaugural do MAR, Martins (2013) caracterizou a instituição como um museu de muitas contradições. Segundo o autor, por um lado, havia quem alegasse que o novo espaço era apenas uma "locomotiva da especulação imobiliária", por outro, existia quem o defendesse enquanto um novo local para a arte na cidade, uma possível superação da histórica deficiência de acervos institucionais no Brasil.

Conforme apresenta o autor, a arquitetura do MAR estrutura uma rota de visita que se inicia pela Escola do Olhar, passando depois para o Palacete Dom João VI, o pavilhão de exposições, em um percurso que vai de cima a baixo. A visita começa na cobertura do primeiro edifício, de onde se tem uma vista da 
região portuária e da Baía de Guanabara. Martins (2013) descreve que foram colocados monitores nesta área, de onde o visitante podia ver como ficaria a conclusão do projeto Porto Maravilha, ainda em construção. Segundo ele, essa técnica na arquitetura é chamada de rendering, um procedimento muito usado no mercado imobiliário, que inseria ainda mais o contexto de construção do museu dentro do projeto de especulação imobiliária e de marketing da cidade. Ainda quanto à arquitetura, o autor destaca o fato de que a passarela, que leva o visitante entre um prédio e outro, do ponto de vista da Avenida Venezuela, que não entrou no projeto de obras do porto, é esteticamente mal planejada, o que evidencia que o museu foi criado para um tipo específico de apreciador, aquele que o observa de frente, a partir da área turística da cidade. Kamita (2013 apud MOTTA, 2018) também aponta que o MAR foi planejado em uma integração direta e exclusiva com a Praça Mauá, ignorando a área de trás dos edifícios que o constituem.

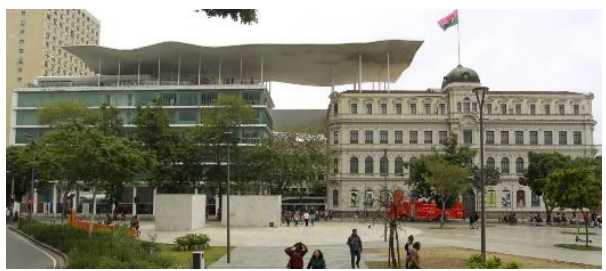

Figura 7: Vista do MAR a partir da Praça Mauá. Foto: Gabriel de Paiva

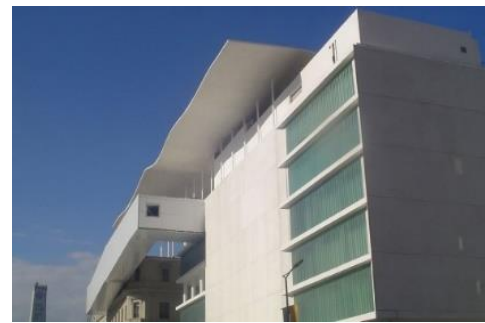

Figura 8: Vista do MAR a partir da Av. Venezuela. Foto: João Masao Kamita.

Almeida \& Ribeiro (2013) também tecem críticas a respeito da passarela de acesso e da rampa de saída, devido ao fato de serem completamente fechadas, não permitindo o olhar para fora. Há de se considerar, no entanto, que o mais coerente é que um museu convide para dentro e não para fora.

Em artigo que teve como base uma experiência de residência pedagógica no MAR realizada pelo grupo de pesquisa Currículo, Espaço, Movimento (CEM), da Universidade do Vale do Taquari (UNIVATES) junto ao Conselho Nacional de Desenvolvimento Científico e Tecnológico (CNPq), Munhoz et al. (2016) narram uma cena em que um educador do museu, em uma visita educativa com um grupo escolar, se vale do mesmo elemento arquitetônico para engajar as crianças na visita de uma forma divertida e lúdica.

Logo em seguida, chegamos ao longo corredor que liga a Escola do Olhar aos espaços expositivos. Há uma porta de vidro separando as crianças desse espaço. Nesse momento, o educador convida-os para realizarem juntos uma viagem no 
tempo, anunciando que eles estavam prestes a percorrer uma passagem mágica. Empolgadíssimas com a proposta, as crianças acompanham atentas os movimentos do educador. Abrindo a porta de vidro lentamente, ele convida: vamos atravessar o tempo? Extasiadas e ansiosas com a ideia da viagem, as crianças iniciam sua travessia pelo "túnel do tempo" e assim chegam ao primeiro andar de exposições. Curiosos com as obras históricas expostas, começam a fazer perguntas sobre os diversos mapas dispostos na primeira parede. Histórias inventadas circulam em voz alta. A viagem aconteceu. (MUNHOZ et al., 2016, p. 376).

O evento narrado é um exemplo do que me referi em Rebouças (2020) como uma experiência de submersão, que é parte essencial para um "mergulho no MAR”. A visita ao MAR, portanto, tem seu início subindo pelo elevador que leva à cobertura do prédio da Escola do Olhar. $\mathrm{O}$ acesso ao segundo prédio, o Palacete Dom João VI, se dá através da passarela fechada. E, assim como a passarela, uma onda de concreto suspensa cumpre a função de ligar os dois edifícios.

Os aspectos arquitetônicos fazem parte de uma narrativa museográfica maior que inclui o jogo metafórico com o nome pelo qual o Museu ficou mais conhecido, MAR, e sua referência à identidade do Rio enquanto uma cidade litorânea. Para entrar no mar, é preciso saber nadar e daí o conceito educacional fundamentando a concepção do Museu. Para entrar nesse MAR, é preciso passar primeiro pela Escola do Olhar, que abriga o setor educativo. Dessa superfície, parte-se para um mergulho na arte e na história cariocas. O mergulho, que, a princípio, é metafórico, torna-se concreto com o percurso de visitação. Na proposta de curadoria conceitual, a passarela, que liga um prédio ao outro, dentro das exposições, passa a compor uma de suas obras de arte, inserindo o visitante dentro do novo universo que ali se abre, como uma experiência de submersão. (REBOUÇAS, 2020, p. 221).

Ramos (2014) interpreta a ligação entre um prédio antigo, o Palacete Dom João VI, e um moderno, o edifício da Escola do Olhar, na composição do museu como uma maneira de tornar visível a missão do MAR de ligar a memória passada a um futuro projetado por meio da educação.

Segundo a descrição da autora, o palacete, que abriga as mostras principais, conta com oito salas de exposições. O prédio anexo, que recebe o nome de Escola do Olhar, acolhe, além do setor educativo, a biblioteca, uma pequena sala de exposições $^{58}$, bem como outros espaços para cursos, seminários e outras atividades. No térreo, há uma área externa, onde também ocorrem alguns eventos gratuitos como shows de música e dança, entre outras atividades culturais.

\footnotetext{
${ }^{58} \mathrm{~A}$ biblioteca e a sala de exposições anexa ainda não estavam prontas na época da monografia de Ramos (2014), por isso, não são citadas nela, mas foram incluídas na presente dissertação para uma descrição mais apurada do espaço físico da instituição.
} 
De acordo com Ramos (2014), o MAR possui um projeto de sustentabilidade precursor em nível nacional. O museu recebeu por este projeto uma certificação internacional ${ }^{59}$, que leva em conta a reutilização de águas pluviais nas descargas sanitárias, a utilização de madeira certificada, a aplicação de vidros com tecnologia de potencialização energética, com o aproveitamento de iluminação e conforto térmico naturais, entre outras estratégias sustentáveis.

Ramos (2014) afirma que o MAR se destaca ainda em relação à acessibilidade, tendo elevadores, rampas de acesso, sanitários apropriados para cadeirantes, cadeiras de rodas disponíveis para pessoas com baixa mobilidade, referências bilíngues e em braile, audioguias e equipe de orientação em cada seção expositiva. A autora destaca ainda como recurso de acessibilidade para pessoas com deficiência visual ou baixa visão a maquete tátil do museu, no quinto andar da Escola do Olhar.

Na cobertura da Escola do Olhar, conforme discute Ramos (2014), há uma área de socialização, um restaurante e um mirante, de onde se vê a Baía de Guanabara e a Praça Mauá. No térreo, havia ainda uma cafeteria e uma loja de souvenirs e livros. Em visita realizada no início de 2020, pude observar que a cafeteria não existia mais, porém havia, então, um quiosque que vendia café. Além disso, na loja que, anteriormente, vendia souvenirs, eram vendidos apenas os catálogos das exposições do museu.

Quanto ao mirante, ele parece constituir um dos elementos que o público em geral mais gosta no MAR. Em pesquisa na qual compara as selfies ${ }^{60}$ publicadas no Instagram com marcação de hashtags $^{61}$ referentes ao MAR e ao Centro Cultural Banco do Brasil (CCBB), Silva (2018) constatou que, ao contrário do que esperava, o percentual de selfies tiradas no MAR é maior do que no CCBB. Em

\footnotetext{
${ }^{59}$ Ramos (2014) se refere aqui ao selo Leed (Leadership in Energy and Environmental Design Liderança em Energia e Design Ambiental), pelo World Green Building Council (Conselho Mundial de Construções Ecológicas), um sistema internacional de certificação e orientação ambiental para edificações.

${ }^{60}$ A selfie é uma fotografia, geralmente feita com um celular ou uma câmera digital, que a pessoa realiza de si mesma, seja segurando o aparelho e esticando o braço, seja com o uso de algum equipamento, como um bastão. O fotógrafo pode se fotografar sozinho ou com outras pessoas. $\mathrm{O}$ mais comum é que este tipo de foto seja realizado com o uso da câmera frontal do celular smartphone, de maneira que o fotógrafo pode se ver na tela do aparelho no mesmo momento em que fotografa. É comum que esse tipo de foto seja publicado em redes sociais com o uso da hashtag \#selfie.

${ }^{61}$ Hashtags são as palavras-chave de uma publicação em redes sociais. Elas são marcadas pelo símbolo \#. O objetivo dessa marcação é tornar mais fácil a busca por publicações de mesmo tipo.
} 
sua visão, uma possível justificativa consistiria nas fotos tiradas no mirante da Escola do Olhar, que correspondiam a $28 \%$ das selfies realizadas no MAR. A autora observou ainda que as exposições eram o assunto mais abordado nas publicações sobre as duas instituições. No caso do $\mathrm{CCBB}$, o segundo assunto mais comentado era a arquitetura do centro cultural e o terceiro, as peças de teatro. Em relação ao MAR, o segundo assunto mais mencionado era a vista do mirante e o terceiro, a arquitetura.

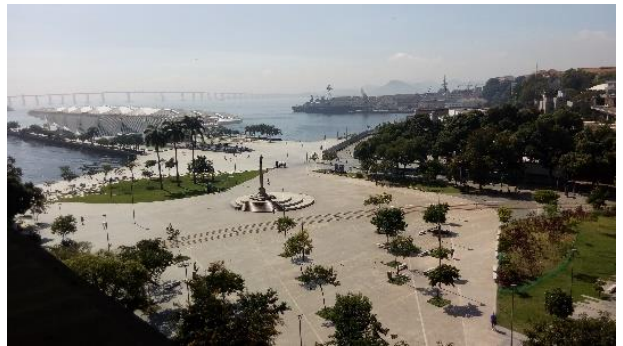

Figura 9: Vista da Praça Mauá em um dia de sol, a partir do mirante da Escola do Olhar. Registro da autora, 2019.

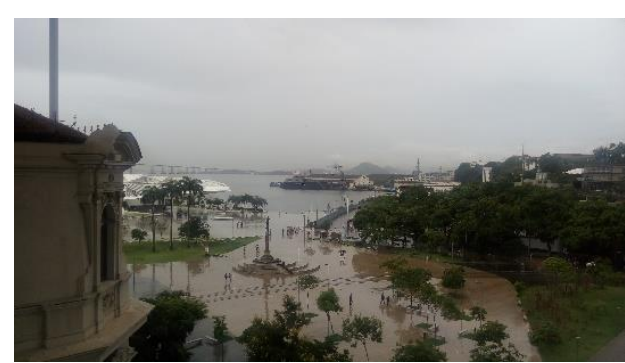

Figura 10: Vista da Praça Mauá em um dia de chuva, a partir do mirante da Escola do Olhar. Registro da autora, 2020.

Além da arquitetura, Martins (2013) tece considerações sobre as primeiras exposições que ocuparam o MAR: Rio de Imagens; O Colecionador; Vontade construtiva na Coleção Fadel ${ }^{62}$; e $O$ Abrigo e o Terreno. Em relação à primeira, o autor a coloca como o ponto alto, mostrando tanto a beleza quanto a instabilidade das paisagens que formam o cenário carioca. Menciona ainda o fato de as duas exposições seguintes refletirem um primeiro momento da concepção do museu, que logo foi abandonada, a de que ele se dedicaria a exposições de colecionadores particulares.

O autor conclui sua análise de maneira bastante crítica à instituição, principalmente em relação a sua forma de financiamento e à sua ligação com a Fundação Roberto Marinho (FRM) e ao modelo de museu-símbolo de cidades globais que esta já vinha implementando com seus investimentos no campo das artes, na cidade de São Paulo ${ }^{63}$. A posição adotada pelo autor ecoa muitas críticas

${ }^{62}$ O Colecionador: Arte brasileira e internacional na coleção Jean Boghici (03/2013 - 09/2013), curadoria de Leonel Kaz e Luciano Migliaccio.

Vontade Construtiva na Coleção Fadel (03/2013 - 10/2013), curadoria de Paulo Herkenhoff e Roberto Conduru.

${ }^{63}$ O Museu da Língua Portuguesa e o Museu do Futebol, ambos na cidade de São Paulo, são frutos de parceria entre o poder público e a FRM. 
que outros jornalistas, acadêmicos, artistas e a população de uma maneira geral fez e ainda faz ao MAR.

D’angelo (2013), por outro lado, mostra uma perspectiva mais positiva em relação à inauguração do museu, ressaltando a proposta educacional em diálogo com a arte como um elemento audacioso e dissonante dentro do novo equipamento cultural da cidade.

Para Ramos (2014), um dos elementos que compõem o diferencial do MAR e que mais caracteriza este museu como "do carioca" é a relação que ele estabelece com o entorno, principalmente através do Projeto Vizinhos do MAR, que realiza atividades como o oferecimento de visitação gratuita para os moradores da área e também reuniões e cafés-da-manhã, onde buscam o diálogo com os mesmos sobre as ações do museu. O projeto é destacado pela autora como uma possibilidade de integração territorial e de troca dialógica entre o museu e a população local. Segundo Ramos (2014), no balanço de gestão de 2013, o programa possuía um total de 1.518 inscritos. Segundo Carlos Gradim, em participação no Seminário O Terceiro Setor na Gestão da Cultura (MAR, 2017, vídeo 5), em seus primeiros quatro anos, o MAR já tinha 4 mil e 200 Vizinhos cadastrados.

Em relação à proposta educacional, Ramos (2014) aponta que o MAR tem parceria com a Secretaria Municipal de Educação e, assim, estabelece contato com o corpo docente e discente de escolas municipais. De acordo com a autora, da sua inauguração até março de 2014, o MAR já havia recebido cerca de 40 mil estudantes e mais de dois mil professores. A autora evidenciou, a partir de um acompanhamento das programações e de visitas de observação, que a presença da escola no museu é, de fato, muito intensa.

Ramos (2014) destaca que o MAR oferece cursos e oficinas, alguns voltados especificamente para professores da rede pública, outros, para o público em geral. Os eventos abordam vários assuntos, mas especialmente educação e arte. Além disso, outra atividade oferecida é a Conversa de Galeria, na qual artistas vão ao museu e debatem suas obras com o público, ou ainda os próprios educadores realizam um encontro para provocar o público com algumas questões sobre arte e outros assuntos transversais. A autora ressalta também as parcerias que o MAR tem com algumas universidades como parte do programa MAR na Academia. Segundo a autora, em 2014, a instituição já tinha como parceiras, além 
da UFRJ, que já foi mencionada, a Universidade Federal Fluminense (UFF) e a Universidade do Estado do Rio de Janeiro (UERJ). Embora a autora não mencione este fato, o MAR tem ainda uma parceria com a Pontifícia Universidade Católica do Rio de Janeiro (PUC-Rio), através do curso Trajetórias Judaicas.

A entrada no MAR é gratuita às terças-feiras e, de quarta a domingo, a entrada inteira é $\mathrm{R} \$ 20$, sendo $\mathrm{R} \$ 10$ a meia entrada. Às segundas-feiras o museu fica fechado ao público. Os grupos que possuem direito à gratuidade nos demais dias são idosos, estudantes, crianças com menos de cinco anos, professores da rede pública, guias de turismo, funcionários de outros museus e Vizinhos.

O fato de o museu não ser totalmente gratuito também constitui uma das fontes de polêmica. Silva (2018), por exemplo, escolhe o MAR e o CCBB para seu estudo comparativo sobre selfies, exatamente porque o primeiro tem entrada paga, na maior parte da semana, enquanto o segundo oferece entrada gratuita para todo o público todos os dias. Devido à questão da gratuidade, a autora trabalhou com a hipótese de que o número de selfies tiradas no $\mathrm{CCBB}$ superaria a quantidade de fotos do mesmo tipo tiradas no MAR, o que não se comprovou.

Em sua pesquisa, Silva (2018) concluiu que, apesar das diferenças entre o CCBB e o MAR, as selfies feitas nas duas instituições eram basicamente dos mesmos tipos e com legendas parecidas. A única diferença, segundo ela, é que foram encontradas, em relação ao MAR, um maior número de legendas ligando o museu ao turismo, como "Turistando na própria cidade", já nas fotos tiradas no $\mathrm{CCBB}$, a pesquisadora encontrou mais legendas que mostravam um envolvimento afetivo, como referências ao centro cultural como uma segunda casa, o que ela interpreta como uma maior apropriação da instituição, enquanto as legendas das fotos no MAR denotariam um maior distanciamento.

Há de se destacar que, apesar de não oferecer uma gratuidade extensiva como o $\mathrm{CCBB}$, o MAR tem um apelo muito grande com o público escolar, especialmente com as escolas da rede pública, que, como mencionado em outras pesquisas, é uma das maiores audiências no museu. Uma parte significativa desse grupo não tem 13 anos, a idade mínima para uso do Instagram, segundo as regras da rede, e é possível ainda que, devido à idade e talvez até mesmo ao nível socioeconômico, não tenha um aparelho smartphone para fazer as selfies. Portanto, trata-se de um público que é desconsiderado dentro do corpus da pesquisa em questão. 
Julia Baker, que fazia parte da equipe da Escola do Olhar, em entrevista para Ramos (2014), aponta que o grande diferencial do MAR é a ênfase que a instituição dá à educação. Na palestra de Clarissa Diniz no evento Arte: História, Crítica e Curadoria (MAR, 2014, vídeo 3), um dos presentes parece ter a mesma percepção. Ele afirma que, ao contrário do que é visto em outras instituições, não há, no MAR, uma separação radical entre o educativo e os demais setores do museu. Pelo contrário, os setores educativo e curatorial interagem intensamente. Além disso, afirma que a postura adotada não é paternalista, mas sim dialógica, o que faz com que o educativo funcione também como um "ouvido" do museu. Ele achou interessante ouvir um educador comentando sobre as percepções do público sobre as obras e as exposições, mostrando ter uma escuta ativa.

Também em entrevista para Ramos (2014), o museólogo Mário Chagas discorda que o museu realmente represente uma novidade. Para ele, a importância do MAR é limitada, já que, em sua opinião, o museu não está preenchendo uma lacuna em relação aos espaços culturais da cidade e seu alcance à comunidade local é questionável. Ele argumenta a favor de investimentos públicos em iniciativas populares, como museus de favela. Para Chagas, no lugar de um museu feito por um grupo, no caso, a OS, que realiza ações nesse espaço para a comunidade, o próprio museu poderia ser feito pela comunidade. Afirma ele: "Nada de extraordinário eu vejo ali [no MAR]. [...] Se há uma novidade na museologia brasileira, no campo museal brasileiro eu identifico essas novidades nessas pequenas iniciativas [nos museus de favela]" (Chagas em entrevista para RAMOS, 2014, p. 62).

A perspectiva apresentada pelo museólogo sinaliza as duas contradições que o MAR, em certo sentido, corporifica: seu caráter híbrido, que envolve o uso do dinheiro público e a gestão por OS, e sua própria constituição enquanto parte do projeto Porto Maravilha, que afetou, em alguns casos, bruscamente, a população local com a qual o museu afirma estabelecer uma relação de boa vizinhança.

\subsection{2}

\section{O amor bandido: A gestão por OS}

No site do MAR, são informadas como formas de apoio à instituição os seguintes dispositivos: patrocínios de pessoa física ou empresas privadas, seja com recursos diretos ou por meio de leis de incentivo à cultura (Lei Rouanet, Lei 
Estadual e Lei Municipal de Incentivo à Cultura - Rio de Janeiro), doações financeiras ou de obras de arte para o acervo e parcerias institucionais.

A OS que gerencia o MAR é o Instituto Odeon, criado em 1998 como Odeon Companhia Teatral e, posteriormente, expandido. Segundo o site do museu, “o Instituto Odeon é uma associação privada de caráter cultural, sem fins lucrativos, que tem a missão de promover a cidadania e o desenvolvimento socioeducacional por meio da realização de projetos culturais".

O projeto do museu foi concebido e realizado em uma parceria entre a FRM e a Prefeitura do Rio de Janeiro, tendo o Grupo Globo e a Vale como patrocinadores. Atualmente, o grupo de patrocinadores inclui ainda as empresas Equinor, IRB Brasil, Bradesco Seguros, Itaú, Icatu Seguros, Machado Meyer Advogados, HIG Capital, RIOgaleão e JSL, além de entidades que oferecem patrocínios pontuais para algumas atividades ou eventos. Além disso, a instituição recebe apoio do Governo do Estado do Rio de Janeiro, do Ministério da Cidadania e do Governo Federal.

Em relação à FRM, conforme explica Deca Farroco, gerente de produção da Fundação, em participação no Seminário O Terceiro Setor na Gestão da Cultura (MAR, 2017, vídeo 6), a instituição, considerada uma das pioneiras no modelo de gestão por OS, não gerencia diretamente nenhum equipamento cultural, mas participa da criação, elaboração e implementação de novos equipamentos, se mantendo, posteriormente, como um membro do conselho deles.

Conforme explicitado ao longo do evento \#MARé, em 2020, e do Seminário O Terceiro Setor na Gestão da Cultura, em 2017, o modelo de OS já é a norma em São Paulo, Minas Gerais e em outros estados do Brasil. O Rio de Janeiro foi um dos últimos a aderir a este tipo de gestão. Apesar de ser considerado por muitos uma forma de privatização da cultura, ele vem sendo visto como a solução para muitos equipamentos culturais manterem seu funcionamento. É crescente o número de equipamentos que vem adotando o modelo de gestão por OS ou ainda outras formas de administração mais ligadas ao privado e menos articuladas com o público.

Muitos museus que ainda não aderiram ao modelo de OS, anunciaram que vão aderir ou que estão considerando a adesão. Em sua participação no Seminário Internacional Desafios dos Museus no Século XXI (CAMARGOS et al, 2018), Martin Grossman fala sobre o Fórum Permanente de Museus, que adotará em 
breve o modelo de gestão por OS. Ricardo Piquet, diretor presidente do Instituto de Desenvolvimento e Gestão (IDG), OS responsável pela gestão do Museu do Amanhã, em participação no evento \#MARé (MAR, 2020, evento 1), informou que esta instituição veio sofrendo cortes de investimentos públicos em seu orçamento, que cresciam ano após ano e, hoje, excetuando-se o incentivo da Lei Rouanet, está funcionando inteiramente com financiamento privado. Algumas pessoas presentes no evento \#MARé que se apresentaram como parte das equipes do Museu Bispo do Rosário e do Museu de Imagens do Inconsciente afirmaram estar no evento para aprender mais sobre o modelo porque estavam considerando a sua adoção. Há, portanto, um motivo para que cada vez mais instituições estejam vendo no modelo uma possível alternativa.

O Seminário O Terceiro Setor na Gestão da Cultura, cujo objetivo era debater a atuação das organizações sociais e gestoras de projetos em instituições e outras iniciativas culturais do poder público, ocorreu em vista da publicação do livro de mesmo nome, organizado por Carlos Gradim, presidente do Instituto Odeon.

No evento (MAR, 2017, vídeo 5), Gradim afirma que 49\% do orçamento do MAR é proveniente de repasse municipal, sendo, portanto, mais da metade, 51\%, resultante da bilheteria e da captação de recurso, ou seja, da atuação da OS junto ao setor privado.

Beth Ponte, diretora do Instituto de Ação Social pela Música, primeira OS da área da cultura a realizar um contrato de gestão com o Estado da Bahia, em participação no seminário (MAR, 2017, vídeo 5), diz que, apesar de o modelo de gestão por OS ainda precisar de melhorias e de todas as críticas que ele enfrenta, continua acreditando nele. Em sua concepção, a gestão por OS não é a solução real para o problema da falta de investimentos e da má administração no setor cultural, mas foi a solução possível. E acredita que seja irreversível, uma vez que o modelo já demonstrou amenizar muitos problemas enfrentados anteriormente com a gestão direta do Estado, além de outras contribuições. Outros expressam opiniões semelhantes, mostrando não acreditar que o modelo de gestão por OS seja o ideal, mas foi uma boa solução para manter equipamentos culturais em funcionamento.

Ponte também destaca que é preciso ter cautela ao criticar o modelo porque a contestação por grande parte da sociedade atualmente não é apenas em relação à 
gestão por OS na área da cultura, mas sim à própria cultura e ao investimento nela. Oferece como exemplo o caso do prefeito de São José dos Campos, São Paulo, Felício Ramuth, que anunciou, em uma transmissão ao vivo em suas redes sociais, que iria acabar com a orquestra sinfônica municipal, de 35 anos, porque era preciso investir no que era "realmente prioritário". A orquestra, que gastava cerca de $0,2 \%$ do orçamento da Prefeitura, acabou, deixando mais de 45 pessoas desempregadas. Grande parte dos comentários deixados na rede, segundo ela, apoiavam o prefeito em sua decisão. Ponte argumenta que, dentro da atual conjuntura política, é necessário não só mostrar a relevância do modelo, mas também da cultura.

Claudineli Ramos, historiadora e pesquisadora da Secretaria de Cultura de São Paulo, que também participou do evento (MAR, 2017, vídeo 7), menciona que, apesar de soar como heresia a pergunta se a cultura é um valor público e se o Estado deve investir nela, o cenário mundial mostra que agora, mais do que nunca, é importante estar apto a respondê-la ${ }^{64}$. No entanto, argumenta que assumir algo como um valor público implica em considerar as condições para transformar aquilo em realidade, o que significa pensar no orçamento. Ramos questiona ainda com quais propósitos a cultura deve ser política pública. Afirma ela que, conforme está na Constituição, o Estado deve ser um indutor de políticas públicas, mas, em relação à execução, ele tem como alternativas: se incumbir dela, fazê-la em parceria com a sociedade, delegá-la ou terceirizá-la completamente. Segundo Ramos, ter os objetivos claros é essencial para pensar no planejamento e, posteriormente, na prestação de contas, que deve se dar não apenas no sentido de conferir como o dinheiro foi investido, mas também de verificar se aquele recurso público alocado em uma finalidade cultural representa para a sociedade um valor.

Em relação ao questionamento do valor público da cultura, Ramos declara que a Secretaria do Estado de São Paulo responde a ele afirmando o lugar da cultura dentro do âmbito simbólico da formação das identidades individuais e coletivas e dos legados sociais, como um conteúdo indispensável para o desenvolvimento do respeito à diversidade humana e para o pleno exercício da

\footnotetext{
${ }^{64}$ Ponte e Ramos se referem aos ataques que a área cultural veio sofrendo na última década, que, no Brasil, se fortaleceram, em especial, devido a uma má interpretação da Lei Rouanet, e que teve como um dos reflexos a extinção do Ministério da Cultura (cf. CHAVES, 2019; JORNAL NACIONAL, 2016; ROSÁRIO, 2016; TURINO, 2019).
} 
cidadania e, portanto, um direito, além de compreendê-la como um elemento que conduz a economia e a sociedade ao desenvolvimento sustentável.

Piquet, ao participar do evento \#MARé (MAR, 2020, evento 1), traz o exemplo do MAR Vive para argumentar que o sucesso de um equipamento cultural pode ser visto na importância que a sociedade dá a ele. Quando sob o risco de fechar, a sociedade civil se mobiliza para impedir que isso aconteça, o equipamento cultural mostra o seu valor.

O MAR Vive foi um movimento organizado pela sociedade civil para impedir o fechamento do MAR no ano de 2019, quando foi anunciado em muitos meios de comunicação que a instituição não vinha recebendo verbas da Prefeitura e que um grande número de funcionários já estava recebendo aviso prévio.

Quanto às argumentações contrárias ao modelo de OS, para Ramos (MAR, 2017, vídeo 7), "vive-se um amor bandido na área cultural" e "tem um monte de coisas que não pegam bem”. Entretanto, é necessário ter em mente a conta a ser paga, uma vez que, além do custo do próprio equipamento ou evento, a área emprega direta e indiretamente muitas pessoas, que precisam receber por seus serviços.

A respeito do que necessita ser melhorado, Beth Ponte (MAR, 2017, vídeo 5) afirma que o que o governo federal tem como lei de parceria com OS não prevê uma parceria real, em que ambos, governo e OS, atuariam de igual para igual. Há uma falta de diálogo entre as diferentes instâncias e uma falta de clareza sobre o funcionamento desse modelo de gestão. No entanto, acredita que os problemas mais concretos sejam os financeiros. É comum que, após assinar com uma OS, o governo simplesmente deixe de disponibilizar o recurso ou o diminua, deixando para a OS a incumbência de encontrar uma alternativa. Um processo semelhante aconteceu no MAR, que suscitou a crise de 2019, e também no Museu do Amanhã, que fez com que a gestão optasse por trabalhar apenas com financiamento privado.

Marília Bonas, diretora executiva do Instituto de Preservação e Difusão da História do Café e da Imigração em São Paulo, em apresentação no mesmo evento (MAR, 2017, vídeo 5), em relação às questões financeiras que envolvem o modelo, destaca que, em contextos de contingenciamento, quando uma das partes deixa de prover com os custos necessários para a manutenção do equipamento, as áreas finalísticas são as mais afetadas. As áreas jurídicas, contábeis e de 
controladoria não podem sofrer cortes muito grandes, porque são essenciais no próprio cumprimento do contrato de gestão. Logo, quando há uma redução orçamentária, os cortes são realizados quase integralmente na área finalística, ou seja, nos setores educativo, de pesquisa e de preservação. Outra opção é condicionar o funcionamento desses setores à captação, o que, segundo Bonas, já é feito em alguns museus em São Paulo. Ela alerta que os cortes nestes setores levam ao questionamento da própria existência da instituição.

A narrativa de Pucu (2019) ${ }^{65}$ a respeito das mudanças ocorridas na Escola do Olhar constitui um exemplo dentro da própria experiência do MAR de como os contingenciamentos incidem sobre o setor educativo. A princípio, relata que houve uma mudança de gestão da Escola do Olhar em 2018, quando Janaina Melo deixou o cargo de coordenadora e ela, Izabela Pucu, passou a ocupá-lo. A respeito da mudança, afirma que a equipe teria sido integralmente mantida. No entanto, em outros momentos do mesmo texto, ela se refere a reduções no número de educadores, à rotatividade e ao acúmulo de funções deste grupo, além de também se referir a educadores que não estão mais na equipe.

Lopes (2019), ao se referir ao programa de formação continuada da equipe do educativo no MAR, destaca que, em 2017, o museu teve uma diminuição orçamentária que resultou na redução da equipe e em dificuldades para manter o programa de formação nos mesmos moldes. A autora sinaliza ainda que outro elemento da formação perdido devido ao corte de verbas foi o convite de especialistas para ministrar práticas formativas.

O corte de verbas na área da cultura foi apontado pelas três instituições pesquisadas por Lopes (2019), dentre elas o MAR, como uma das principais dificuldades na elaboração de uma formação interna de qualidade. A diminuição orçamentária causa não somente a diminuição da equipe, como também a concomitante sobrecarga de trabalho, o que impossibilita a participação em eventos de formação e atualização. Em entrevista à autora, uma das educadoras comenta sobre como a equipe de educação foi afetada pela redução orçamentária.

${ }^{65}$ PUCU, I. Objetos-limite e outras práticas experimentais de educação e arte no MAR. In: PUCU, I.; NICHOLS, N.; ZACA, R. (org.). Dispositivos Artístico-Pedagógicos. Rio de Janeiro: Instituto Odeon, 2019. 
Temos um Programa de Formação Continuada de equipe, é interno, com uma metodologia de Grupos de Trabalho [GTs] onde toda a equipe se divide entre quatro temas. [...] Em maio [de 2017] nós tivermos uma reestruturação da equipe, que foi reduzida à metade por corte de verba e não pode ser mais dessa forma. Antes, nós tínhamos os encontros em todas as segundas-feiras, que nos era muito valioso. Em uma semana tínhamos uma formação nossa, só da Equipe de Referência (Educadores de Projetos e os Educadores Sêniores) [...] e na semana seguinte era a formação com a equipe inteira junto. Essa formação com a equipe inteira era quinzenal. Agora, por uma questão de escala, não conseguimos mais reunir a equipe inteira na segunda-feira e os quatro GTS de estudos foram reduzidos à um - que é geral. Isso tem prejudicado muito nossa estrutura, obviamente! (Clarisse, educadora de projetos em entrevista para LOPES, 2019, p. 139).

Outro reflexo do corte de verbas na área da cultura em relação à educação em museus, conforme aponta Lopes (2019), está na falta de transporte para levar grupos escolares e não escolares.

Nesse sentido, Gradim, em participação no Seminário O Terceiro Setor na Gestão da Cultura (MAR, 2017, vídeo 5), relata que, inicialmente, a Prefeitura do Rio disponibilizava ônibus para as escolas municipais levarem os alunos para visitas educativas no MAR. Entretanto, a quantidade de fornecimento desses ônibus sofreu uma significativa diminuição. A fim de manter o mesmo fluxo de estudantes, o Instituto Odeon realizou uma parceria com a Fecomércio, na qual surgiu o projeto Partiu MAR, que não apenas disponibilizava o transporte para as escolas como também oferecia um programa de formação para os professores.

Gradim menciona ainda a parceria entre o Instituto e o Banco Nacional de Desenvolvimento Econômico e Social (BNDES) no projeto de ampliação da reserva técnica, que foi necessário em vista do crescimento do acervo do museu. Para ele, estes são dois exemplos da atuação da OS em situações extremas, que só foram possíveis porque uma das atribuições das OS é buscar parceiros para executar projetos.

\subsection{3}

\section{Um novo museu aporta no Porto Maravilha}

Em 2009, o Rio de Janeiro foi escolhido como cidade-sede das Olimpíadas de 2016. Este seria, conforme aponta Nobre (2016), apenas um capítulo em um longo calendário de megaeventos no qual o Brasil se envolveu, depois de um extenso intervalo de estagnação cultural e econômica, desde a mudança da capital para Brasília, na década de 1960. Às vésperas dos Jogos Olímpicos, como ressalta a autora, a cidade do Rio de Janeiro se encontrava repleta de novos projetos em 
desenvolvimento, muitos dos quais já demonstravam que não seriam terminados a tempo.

Entre as obras realizadas para a preparação da cidade para o evento, na zona portuária, teve início a operação urbana Porto Maravilha, criada a partir de um convênio em regime de PPP. A Praça Mauá seria uma espécie de hall do Porto Maravilha. Segundo Motta (2018), os agentes estatais e privados, que estavam à frente dos grandes eventos esportivos e das reformas urbanas que os acompanharam, propagavam os mesmos como o ápice do processo modernizador e democratizante, que começou com a vitória da esquerda na eleição presidencial de 2002.

Nobre (2016) se refere ao cenário político prévio aos Jogos Olímpicos como de euforia. A economia do Brasil ia bem e se desvencilhava de uma crise internacional, e os megaeventos, que atraíram ainda mais investimentos estrangeiros, além de movimentar o campo cultural, trouxeram ainda mais otimismo. No entanto, ao final dessa fase, teve início o impacto da crise econômica internacional no país e a população começou a questionar o alto custo de vida que não condizia com a qualidade dos serviços públicos prestados. Esse questionamento teve início em relação ao sistema de transporte, que havia recentemente aumentado o preço das passagens dos ônibus urbanos, e depois se estendeu para outras áreas, gerando uma onda de protestos por todo o país, que culminaram no pedido de impeachment presidencial.

Durante os primeiros anos de governo do Partido dos Trabalhadores (PT), conforme discute Motta (2018), a economia brasileira sofreu uma reprimarização ${ }^{66}$, que gerou muitos lucros, que, em parte, foram aplicados no mercado de arte interno. O mercado local de arte contemporânea estava cada vez mais atrelado ao mercado global. Ao passo em que a cultura brasileira, como sinaliza o autor, ascendia em importância no mercado externo, internamente, o mercado de galerias comerciais de arte se ampliava, saindo até mesmo do eixo Rio-São Paulo.

Além disso, em 2010, seguindo o modelo de sucesso da SP-Arte, com início em 2005, surgiu, no Rio de Janeiro, a ArtRio, uma feira internacional de galerias,

\footnotetext{
${ }^{66}$ Reprimarização indica um processo pelo qual um país passa a exportar mais produtos primários do que industriais.
} 
realizada em um galpão reformado da área portuária. Motta (2018, p. 154) vê o surgimento da ArtRio como um elemento a mais dentro das perspectivas simbólicas, permeadas por mercadorias culturais, que projetavam o Brasil enquanto um "paraíso pacificado de consumo" e da elevação do Rio de Janeiro ao nível de cidade global, onde o tecido urbano é incorporado à forma-mercadoria.

Conforme assinala Rolnik (2015 apud MOTTA, 2018), a princípio, a área portuária não estava dentro do dossiê da candidatura do Rio de Janeiro para as Olimpíadas de 2016. Não obstante, em 2009, ela veio a se tornar um dos principais elementos do projeto. A área já constituíra matéria de muitas propostas de reforma que nunca se concretizavam por falta de alinhamento políticopartidário entre o governo federal, que detinha $62 \%$ da zona portuária como sua propriedade, o municipal e o estadual. Somente depois da aliança política entre o PT e o Partido do Movimento Democrático Brasileiro (PMDB), o projeto de revitalização, surgido de uma proposta da empreiteira OAS, começou a tomar forma.

Nascia, assim, o projeto Porto Maravilha, que, com inspiração em experiências que já haviam ocorrido em outros países, tomava equipamentos culturais como base estratégica para reforma física e simbólica do espaço urbano, em um "modelo olímpico" de gestão urbana, um tipo de administração que utiliza dinheiro público para financiar projetos de infraestrutura, escondendo uma crise econômica urbanística. Segundo Botelho (2017 apud MOTTA, 2018), este tipo de modelo visa obter resultados passageiros, mas não solucionar de fato a crise, que tende a se intensificar, passados os megaeventos. Afirma ainda Motta (2018) que, para que estes benefícios sejam estendidos, a cidade se empenha em sediar, no menor intervalo possível, o máximo de eventos que conseguir. Neste contexto, o autor recorda que, entre 2007 e 2016, ou seja, em menos de dez anos, o Rio de Janeiro recebeu os Jogos Pan-Americanos, os Jogos Militares Mundiais, a Copa das Confederações, a Copa do Mundo, a Jornada Mundial da Juventude e os Jogos Olímpicos. Além destes eventos, Nobre (2016) também menciona a Conferência das Nações Unidas para o Desenvolvimento Sustentável Rio +20.

Nesse contexto, como descreve Motta (2018), três importantes setores do capital, construção civil, serviços urbanos de infraestrutura e incorporação imobiliária, convergiram em um único consórcio, que recebeu o nome de Porto Novo, do qual participavam as empresas OAS, Odebrecht e Carioca Christiani- 
Nielsen Engenharia. Este consórcio foi encarregado de administrar a PPP do Porto Maravilha, projeto de revitalização da região portuária, dentro do qual o MAR e o Museu do Amanhã foram criados. O autor se refere a estes dois museus como "meios-irmãos" por dividirem a mesma "casa", a Praça Mauá, e também terem sido ambos parte da mesma iniciativa.

Para Motta (2018), o resultado mais duradouro da reforma urbana foi a forma como afetou as populações, em sua maioria, negras e pobres, que moravam na área. Segundo o autor, a gentrificação, na área do porto do Rio, aconteceu de forma direta, com as remoções e demolições, mas também indireta, com o aumento do custo de vida. Entre os casos de remoção, Laranja (2011 apud MOTTA, 2018) destaca aquela feita na Ocupação Zumbi dos Palmares, a maior ocupação da cidade, que resistiu entre 2005 e 2009 no antigo prédio abandonado do Instituto Nacional do Seguro Social (INSS), na Avenida Venezuela. Em 2020, o prédio seguia desabitado, sem uso e, agora, interditado pela Defesa Civil.

Conforme a análise de Motta (2018), o Porto Maravilha seguia o exemplo do Governo de São Paulo em relação à revitalização da área da Estação da Luz, que teve a reforma da Pinacoteca do Estado como âncora cultural e onde, na ocasião, atuaram coletivos de arte em articulação com movimentos de moradia. Para o autor, a ideia inicial de criar uma pinacoteca do Rio revelava a inspiração na experiência paulistana. Foi, então, elaborado, entre 2009 e 2011, o projeto da Pinacoteca Escola do Olhar, que teria como diretor cultural Leonel Kaz, idealizador do Museu do Futebol, em São Paulo, e com experiência em gestão cultural por OS. O projeto da pinacoteca foi reformulado, em 2012, a partir da entrada de Paulo Herkenhoff na direção cultural da instituição. Kaz, posteriormente, veio a trabalhar na curadoria de algumas exposições do MAR, que, em certo nível, ainda guardavam resquícios do projeto inicial do museu como uma pinacoteca para exibição do acervo de colecionadores particulares, como $O$ Colecionador.

Apesar de nascer em meio a grandes contradições e manifestações contrárias à sua existência, como sinaliza Motta (2018), o MAR foi inaugurado trazendo para a galeria, com $O$ Abrigo e o Terreno, o debate proposto pelos artistas 
emergentes $^{67}$, em grande parte, rotulado como "arte política", que abordava os conflitos sociais, especialmente aqueles em torno da temática da moradia. Além disso, trazia um robusto projeto pedagógico, com um foco significativo na rede pública de ensino, que recebeu o nome de Escola do Olhar. A instituição, como assinala o autor, tem como eixo estruturante da sua programação a arte contemporânea e, a partir dela, são planejadas as demais atividades.

O MAR é formado por um complexo arquitetônico de dois edifícios adjacentes que foram reformados, um em estilo modernista, da década de 1940, e um palacete eclético, dos anos 1910. O projeto de reforma é assinado pelos escritórios Bernardes e Jacobsen. Para Kamita (2013 apud MOTTA, 2018), dois elementos da arquitetura se destacam em relação à experiência do visitante. Um deles é a conciliação estética de dois edifícios construídos em épocas e sob modelos arquitetônicos diferentes, modernismo e ecletismo. $\mathrm{O}$ outro é a fruição da paisagem urbana, conjugada com o cenário natural da Baía de Guanabara, proporcionada pela vista do mirante da Escola do Olhar, que, como já descrito, articula-se à própria trajetória da visita.

A respeito da junção dos dois edifícios, Almeida \& Ribeiro (2013) afirmam que o Palacete Dom João VI foi construído para servir como sede da Inspetoria Federal de Portos e o edifício modernista já abrigou anteriormente o Hospital da Polícia Civil José da Costa Moreira e o Terminal Rodoviário Mariano Procópio, no térreo. Em relação à renovação do palacete, as autoras citam o arquiteto Wallace Caldas, que afirma que foi aplicado o princípio museográfico do cubo branco, de maneira que externamente o prédio tem estilo eclético, do início do século XX, mas internamente é ultra moderno, do século XXI. Esse princípio gera bastante polêmica. A estrutura interna do edifício foi esvaziada, dando lugar a duas grandes salas expositivas por andar. Os elementos do antigo prédio ao qual o visitante tem acesso direto no pavilhão de exposições são a escada e o elevador. De dentro do prédio, não se tem a sensação de estar no mesmo palacete histórico que se vê do lado de fora.

\footnotetext{
${ }^{67}$ Segundo Motta (2018), a arte produzida pelos artistas que foram surgindo no final da década de 1990 e início dos anos 2000, foi denominada "emergente" em uma referência tanto ao estágio da carreira de seus produtores, que estavam ainda emergindo enquanto artistas, quanto à designação neoliberal de determinadas camadas da sociedade, ou em sentido mais amplo, determinados países como de economias ou mercados "emergentes", ou "em desenvolvimento", em uma perspectiva que destaca o caráter de jovialidade e contemporaneidade desse tipo de produção.
} 
A respeito do eixo educacional do MAR, Motta (2018) avalia que, especialmente o plano de vincular a nova instituição à rede municipal de ensino, constituía uma maneira de incorporar as demandas populares por melhorias na educação e, ao mesmo tempo, representava um valor que legitimava o novo espaço e justificava as operações urbanas ao redor. Por outro lado, o eixo temático, focado no Rio de Janeiro, condizia com as ações de marketing urbano.

A ideia de ter um eixo temático combinado com o educacional era, como analisa o autor, uma reprodução do que a FRM já havia feito em seus museus paulistanos. Ambos, o Museu da Língua Portuguesa e o Museu do Futebol, trabalham com experiências audiovisuais interativas e têm como público-alvo as famílias e as escolas, o que assegura uma densidade quase certa de visitação.

Ainda em relação à mudança de rumo do MAR, Motta (2018) destaca que duas das exposições inaugurais, $O$ Colecionador e Vontade construtiva na Coleção Fadel, constituíam resquícios da proposta preliminar de exibição de coleções particulares, sem formação própria de acervo. Outra mudança significativa incidiu sobre a linha curatorial de cultura visual do Rio de Janeiro. No momento inaugural, ela veio muito ligada ao marketing da cidade, mas, depois passou a destacar as questões culturais dos grupos subalternizados e seu protagonismo na história da cidade. É possível visualizar essa mudança de tom ao comparar Rio de Imagens, a mostra inaugural desta linha, com exposições posteriores, como Do Valongo à Favela.

No entanto, $O$ Abrigo e o Terreno foi o marco na atualização do projeto cultural do museu, inaugurando na rotina da instituição a arte contemporânea emergente e as práticas colaborativas. De acordo com Motta (2018), a arte contemporânea emergente estava, embora lentamente, ganhando espaço em eventos de curta duração ou mostras temporárias, além de ser incorporada no MAM e em um número pequeno de galerias comerciais maiores, que seguiam um viés mais ousado e arrojado. O diferencial do MAR, segundo o autor, seria o de proporcionar à produção contemporânea uma instituição regular que não só a exibisse, mas também a colecionasse. O autor destaca que "nesta linha modernizadora, ligada à produção artística 'contemporânea', intervém combinadamente duas forças igualmente importantes: a produção artística 'emergente' e sua expressão mediada por um discurso curatorial” (MOTTA, 2018, p. 172, grifo do autor). 
A nova produção de arte contemporânea entrava no museu, mas através de um filtro curatorial, o que criava dentro da instituição um discurso contraditório e complexo. De acordo com Motta (2018), ao passo em que o MAR era elaborado a partir do "alto", ou seja das instâncias política e dos setores de classe alta, os artistas emergentes, associados aos coletivos e envolvidos em práticas colaborativas, incorporavam em sua produção demandas "de baixo", isto é, dos setores mais marginalizados da sociedade.

Além disso, ao passo em que a linha de arte contemporânea reconhecia os artistas mais novos, como sinaliza Motta (2018), as propostas de revisão da história da arte brasileira faziam com que os artistas modernos de renome fossem revisitados, adquirindo um aspecto alternativo atualizado, alinhado com a produção mais recente.

Segundo o autor, o discurso curatorial do MAR trabalha em duas vias. Em uma, ele imprime sentidos, conceitos e perspectiva histórica ao antiintelectualismo e ao imediatismo da maioria da produção emergente dos coletivos. Em outra, ele aplica um filtro de qualidade estética às manifestações mais carentes de forma ou consistência.

Afirma ainda Motta (2018, p. 214) que "os curadores visavam transformar o museu numa plataforma de intervenção no processo produtivo (e de circulação) da 'arte contemporânea'”, na qual eles próprios seriam os protagonistas. Assim, as práticas colaborativas eram absorvidas, com os curadores em uma posição gerencial.

\subsection{4}

\section{O Abrigo e o Terreno}

Como já exposto, O Abrigo e o Terreno foi a primeira exposição da linha de arte contemporânea do MAR. O nome é uma referência ao conto $O$ Mineirinho (1962) de Clarice Lispector, um texto no qual a autora aborda a sua revolta pela execução com treze tiros de um criminoso pela polícia do Rio.

O que Lispector questiona em seu texto não é nem a execução em si, mas a vontade de aniquilação do outro expressa pelos treze tiros. Nesse sentido, a autora fala sobre o terreno como uma camada que está por baixo da "casa fraca" e onde pode-se erguer uma nova casa. Não se trata exatamente da questão da moradia, mas de se colocar no lugar do outro, perspectiva expressa pela afirmação de que 
"o décimo terceiro tiro me assassina" (LISPECTOR, 1999, p. 124). O texto se desenvolve em um sentido de, por um lado, reconhecer que há mais camadas na história do criminoso Mineirinho, que o fizeram "construir essa casa", e, por outro lado, admitir que cada um de nós também se acovarda em uma "casa fraca" - "nós todos somos perigosos" (LISPECTOR, 1999, p. 126). Por isso, Lispector encerra desejando chegar ao que é mais “áspero e difícil”, o terreno.

Se a referência ao terreno, no nome da exposição, vem do conto de Lispector e remete à oposição proposta entre a "casa fraca" e o "terreno", o abrigo seria, de acordo com MOTTA (2018), uma alusão, ainda que indireta, à obra de Lygia Clark, Abrigo Poético (1960).

Segundo Motta (2018), O Abrigo e o Terreno foi uma mostra crucial na mudança de rumo do MAR, de sua primeira elaboração como uma pinacoteca para exibição de mostras temporárias com obras de colecionadores particulares, até sua reformulação como um museu público, com um acervo próprio e com foco na arte contemporânea. Para o autor, o programa expositivo e museológico do MAR passava a trazer e a colocar em interação, a partir daí, dois fenômenos relativamente recentes no campo artístico brasileiro: a curadoria conceitual e as práticas artísticas colaborativas ou coletivas.

Motta (2018) afirma que o marco histórico do primeiro fenômeno é a $24^{\mathrm{a}}$ Bienal de São Paulo, a Bienal da Antropofagia, de 1998, cujo curador-geral foi Paulo Herkenhoff. Já em relação ao segundo fenômeno, o autor considera que ele teve início no final da década de 1990, quando diversos coletivos de artistas começaram a agir, em um processo que veio a ser reconhecido institucionalmente em 2006, na $27^{\text {a }}$ Bienal, Como Viver Junto, com curadoria de Lisette Lagnado.

Quanto ao primeiro fenômeno, a ascensão da curadoria conceitual, como apresenta Motta (2018), ele surge aliado à figura do curador auteur ${ }^{68}$. A curadoria conceitual é o procedimento pelo qual os curadores aproximam em uma mostra objetos diversos, que se apresentam também de maneira diversa para a fruição e o

\footnotetext{
${ }^{68}$ Auteur significa "autor" em francês. No mundo da arte, o termo é usado para se referir a um curador, diretor de cinema ou artista em uma posição de poder ou gestão dentro de uma produção artística com certo grau de coletividade, que deixa nela a sua assinatura, ou seja, exerce na obra a sua autoria, geralmente sob a forma de um estilo estético que se associa ao conjunto de sua obra. A figura do auteur surge dentro do cinema francês da década de 1950, conhecido como Nouvelle Vague, em uma analogia que comparava o diretor de cinema ao escritor e o filme à linguagem escrita, ancorada no conceito de caméra-stylo ou "câmera-caneta".
} 
uso, constituindo a partir dessa organização um discurso imagético perceptível e coerente. A associação do conceito com o de curador auteur encontra-se no fato de que, ao construir este discurso, o curador faz com que a exposição se torne uma obra de arte à parte - uma obra maior formada a partir de outras e da maneira como estas são organizadas, estabelecendo diálogos entre si -, cujo autor, ou seja, o artista, é o próprio curador da mostra. Trata-se, portanto, de uma prática curatorial que induz uma leitura específica das obras a partir de seu conjunto e de como ele é organizado em uma exposição.

O segundo fenômeno mencionado por Motta (2018, p. 17) é a transformação do próprio objeto artístico e das práticas artísticas, que se deu em quatro dimensões: “a) a produção coletivizada, b) as práticas colaborativas, c) a criação de circuitos 'alternativos' para arte 'contemporânea' e d) o uso de materiais nãoconvencionais". Segundo o autor, daí resultam três operações: o barateamento da produção, uma vez que recursos alternativos passam a ser empregados mais frequentemente, tais como performances e intervenções urbanas; o esfacelamento da hierarquia autor-obra-público; e a expansão do espaço de ação da prática artística, que "ganha as ruas" nas intervenções urbanas e participa ativamente nos movimentos sociais.

Segundo Motta (2018), no final da década de 1990, coletivos de artistas começavam a surgir em grande número. De acordo com Mesquita (2008 apud MOTTA, 2018), três principais fatores acarretaram o fenômeno. O primeiro deles é a internet, que começava a se popularizar e a possibilitar a criação de redes de contato; as residências e ocupações constituíam o segundo fator, uma vez que viabilizavam intercâmbios presenciais; por fim, como terceiro fator, há a vontade de transformação através da arte.

Houve ainda influências internacionais que levaram à constituição de coletivos e da arte política emergente. Segundo Motta (2018), no final dos anos 1990 e início da década de 2000, adentrava no campo artístico brasileiro um tipo de produção artística de caráter conceitual e ativista, associada a uma resistência ao neoliberalismo.

De acordo com o autor, os coletivos brasileiros se aproximaram principalmente da discussão sobre a ocupação de espaços públicos e sobre o direito à cidade, que já vinha sendo evidenciada pelo cicloativismo e pelos movimentos sociais populares organizados, como aqueles em defesa do transporte 
público e da moradia. Portanto, as mensagens que os coletivos propagavam se associavam, em certa medida, a uma demanda de longa data dos grupos subalternizados da sociedade. Quanto à forma desta produção, a intervenção urbana colaborativa se destaca como um dos principais artifícios dentro das práticas desses coletivos.

Para Motta (2018), os novos artistas, que apareciam associados aos coletivos, viam o engajamento nas causas políticas como uma necessidade espiritual, enquanto, por outro lado, o formato de produção coletiva com o uso de materiais baratos atendia à sua necessidade material.

Outro elemento que contribuiu para a formação dos coletivos, conforme menciona Motta (2018), foi a ampliação dos cursos universitários de arte, que trouxe para o mercado um contingente significativo de aspirantes a artistas. De acordo com o autor, todo esse pessoal acabava indo para uma espécie de força reserva, ocupando cargos como montadores de obras de arte, assistentes na curadoria, pesquisa ou em outra área. Alguns ainda entravam no mercado exercendo a atividade de educador, sendo talvez este, segundo Motta (2018), o maior setor em termos de número de pessoal e o menor dentro da hierarquia da instituição, excetuando-se dos trabalhadores indiretamente empregados no mercado da arte, como os da área da segurança e da limpeza. O autor sinaliza ainda que é comum a esta categoria viver um contexto de trabalho de variadas formas de superexploração e de precarização. Argumenta ainda que estes profissionais dispõem de certa autonomia para elaborar percursos nas mostras ou até mesmo interpretações das obras e questionamentos para os visitantes, mas sofrem uma espécie de coação, uma vez que se veem impedidos de criticar explicitamente a instituição ou as escolhas curatoriais, o que acaba fazendo com que realizem um trabalho de valor mais propagandístico do que educativo. Assim, conclui que os integrantes dos coletivos, antes de serem inseridos nas instituições como artistas, já ocupavam as suas margens, constituindo sua força de trabalho intelectual secundária e sendo doutrinados pelos interesses institucionais.

$\mathrm{O}$ autor menciona ainda que, no mesmo período, o formato expositivo que dominava era o modelo cenográfico-espetacular, determinado por uma estetização conservadora populista e associado aos grandes eventos de massa. No entanto, as instituições público-privadas ou apenas privadas, amparadas pela renúncia fiscal, procuravam um formato expositivo mais barato e as mostras de arte 
contemporânea passaram a constituir uma solução financeiramente mais interessante. Entretanto, o modelo mais econômico exigia novas estratégias discursivas, que seriam, então, cumpridas pela curadoria.

Apesar da prática colaborativa, que tomava como base a $27^{\mathrm{a}}$ Bienal, Motta (2018) destaca uma inovação importante em relação à prática curatorial contemporânea que era própria da proposta de $O$ Abrigo e o Terreno: a abordagem dos antagonismos e tensões sociais, ao invés do princípio virtuoso de "como viver junto" - nome daquela bienal.

A exposição $O$ Abrigo e o Terreno ocupava os dois salões expositivos do térreo do palacete. Motta (2018) sinaliza a heterogeneidade de dimensões, escalas e dos materiais que compunham as obras e objetos dispostos no salão, que iam de fotografias a instalações constituídas por materiais de construção, passando por documentações visuais e escritas, objetos tridimensionais, livros, entre outros. O autor assinala ainda que os parâmetros de fruição e uso que tais objetos ofereciam destoavam entre si, impondo regimes de atenção de vários tipos. Para o autor, o que as obras tinham em comum era a abordagem da questão do espaço urbano. Os objetos na mostra dialogavam entre si em uma dinâmica entre os conteúdos semânticos do abrigo e da falta dele.

Quanto à organização do espaço físico da mostra, Motta (2018) destaca a utilização do recurso da saturação, no qual diversos objetos de diferentes materiais são acumulados na sala expositiva de maneira a causar uma sensação de confusão. Entretanto, na segunda sala, as paredes diagonais da instalação Poética do Dissenso, que, ao mesmo tempo, a separavam do resto das obras e objetos e a colocavam como um eixo central no fluxo de visitação, tornavam a organização do espaço circular, resultando em um aspecto mais integrado e menos conturbado.
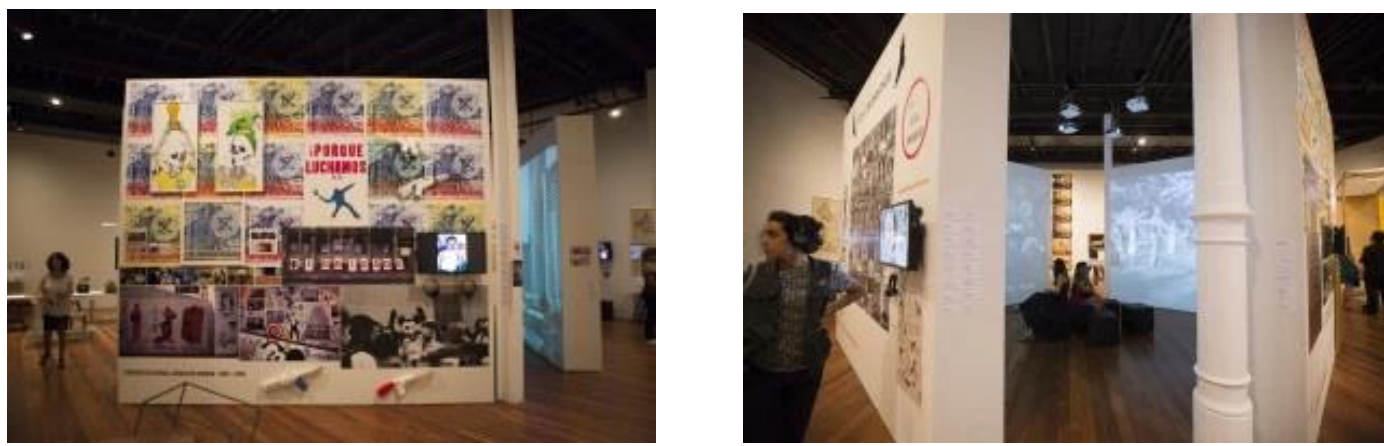

Figura 11: Detalhes de Poética do Dissenso. Fotos: Túlio Tavares 
As paredes que compunham a instalação Poética do Dissenso criavam, no meio da galeria, um outro ambiente. Do lado externo, haviam colados nas paredes cartazes, panfletos, além de uma pequena prateleira com livros e monitores com vídeos. Internamente, o ambiente era escuro e, nas paredes, eram projetados, de forma ininterrupta, 16 vídeos que documentavam as atividades artísticas e o cotidiano das ocupações no centro de São Paulo. As paredes da instalação não se fechavam por completo. De dois lados, havia espaço o suficiente para a entrada e saída dos visitantes e, nas outras duas quinas, existia um espaço de ao menos um palmo separando as paredes. Esse recurso fazia com que tanto a instalação permanecesse sempre visível, estando o visitante dentro ou fora dela, quanto todos os objetos ou obras ao redor do salão.

Segundo Motta (2018), a arquitetura expositiva de $O$ Abrigo e o Terreno, ao fazer uso de tais recursos, recuperava, ao mesmo tempo, os princípios de transparência, ligado à contaminação, da $24^{\mathrm{a}}$ Bienal, e de porosidade, da $27^{\mathrm{a}}$ Bienal.

Conforme a análise de Motta (2018), a 24 $4^{\mathrm{a}}$ Bienal, a Bienal da Antropofagia, trouxe três novidades que influenciaram, em alguma medida, o programa do MAR. A primeira delas é a elaboração de um discurso multicultural associado às estratégias conceituais ao redor da ideia de antropofagia, que, segundo o autor, ressurge com uma interpretação que a coloca como uma tradição local. A segunda foi o recurso curatorial da contaminação, pelo qual obras de artistas de diferentes épocas, consagrados e periféricos, são aproximadas, dentro de uma narrativa maior, histórica e multicultural. E, por fim, a terceira novidade é o destaque que recebe o setor educativo.

Já a $27^{a}$ Bienal, Como Viver Junto, como sinaliza o autor, além do aspecto colaborativo, também trouxe três elementos, que foram aderidos pelo museu carioca. Um deles é o caráter processual, pelo qual a exposição deixa de ser um evento pontual e passa a ser acompanhada por seminários anteriores e simultâneos ao período em que a mostra estivesse em cartaz, além de receber um catálogo, que dá ainda continuidade ao debate e às questões suscitadas. Outro elemento é a encomenda de obras inéditas para os artistas. E, por fim, no lugar da contaminação, havia o princípio da porosidade, segundo o qual, as obras estabeleciam um diálogo por meio do impacto imagético-visual ou imersivo- 
reflexivo, de maneira que a exposição como um todo, em certa medida, parecesse com uma grande instalação imersiva.

Motta (2018) afirma que a curadoria de $O$ Abrigo e o Terreno buscava conjugar uma experiência, ao mesmo tempo, de percepção e de reflexão. Isso era realizado através de um jogo sinestésico, aplicado pelos princípios de saturação, transparência e porosidade e através do conteúdo histórico-conceitual crítico sobre o conflito urbano. $\mathrm{O}$ discurso curatorial funcionava como uma narrativa textual e espacial com uma dimensão performática ou teatral muito evidente, na qual o visitante, em uma espécie de "suspensão da descrença" ou "pacto fíccional", se engajava no universo que ali se abria - "mergulhando" no universo criado.

Para o autor, no entanto, o modelo conseguiu trazer a problemática urbana de uma maneira a denunciar e, ao mesmo tempo, apaziguar o conflito. Motta (2018, p. 233) interpreta o movimento no campo artístico, da ascensão da curadoria conceitual e da entrada institucional dos coletivos de artistas ligados à arte política, como parte da revolução passiva em desenvolvimento no país desde a eleição de Lula à presidência, que "envolveu processos intensos de transformação, estruturados de cima para baixo e marcados pela absorção apenas parcial de demandas dos grupos sociais subalternos".

O autor emprega em sua análise o conceito de "revolução passiva" do marxista italiano Antonio Gramsci, que utilizou inicialmente o termo para se referir a processos históricos de transformações sociais em que o Estado ocupa o lugar de protagonista, mediando o conflito de interesses entre diferentes segmentos de classe na população, e nos quais as classes "subalternas"69 - em tese, as maiores interessadas em mudanças sociais - não participam de forma ativa. A mesma expressão é utilizada por Gramsci para uma interpretação da integração corporativa das classes "subalternas" ao projeto da classe dominante no fascismo italiano. Segundo o autor, o fenômeno age através de uma lógica modernizadora, que atua desde cima. A "revolução" alude a transformações sociais em sentido progressista - ainda que partam da classe dominante -,

\footnotetext{
${ }^{69}$ Motta (2018) utiliza o vocábulo "subalterno" em uma referência direta a Gramsci. No entanto, nesta dissertação, optou-se pelo uso do termo "subalternizado", assim como "marginalizado", "escravizado" etc., com suas variáveis de gênero e número, em um sentido de não naturalizar o contexto de opressão que colocou tais indivíduos nestas condições.
} 
enquanto "passiva" remete à falta de envolvimento ativo das classes "subalternas", cujas demandas são em certa medida absorvidas no processo.

Motta (2018, p. 238) argumenta que alguns processos observados no campo artístico foram consequência da dinâmica de inovação-conservação, que compunha a revolução passiva, engendrada pelo lulismo - "ao custo da desmobilização política das classes subalternas e da integração puramente imagética de suas demandas aos dispositivos culturais institucionais".

Assim, é verdade que $O$ Abrigo e o Terreno trazia para dentro do museu as contradições das quais ele próprio fazia parte, ao mesmo tempo em que, através de um modelo curatorial de vanguarda, inseria o MAR no debate crítico sobre a arte emergente e, deste modo, adicionava as práticas colaborativas e o conteúdo das demandas subalternizadas ao seu programa e acervo. Todavia, na visão do autor, a associação entre a produção artística emergente e a curadoria conceitual, dentro do projeto cultural do MAR, instaurou um discurso socialmente esclarecido, porém, conciliatório, em consonância com o discurso do lulismo, que enfraquecia qualquer potência contestadora das obras.

Desde a exposição $O$ Abrigo e o Terreno, o MAR trouxe a produção artística emergente para a esfera da legitimação e, acompanhando esse fenômeno, deu visibilidade às demandas das camadas mais vulneráveis e a um conteúdo crítico. Esse mesmo conteúdo, segundo Motta (2018, p. 220), "assumia [...] a 'direção moral' da instituição - e a partir daí passava a pautar as demais linhas curatoriais (e as instâncias pedagógicas e editoriais) que compunham o MAR". Para o autor, a direção moral dos "de baixo" encontrava seu limite no consentimento dos "de cima".

Nessa perspectiva, uma mudança pode ser notada na linha de cultura visual do Rio de Janeiro ao comparar as mostras Rio de Imagens, ImagináRIO ${ }^{70}$ e Do Valongo à Favela. Na primeira, instalações multimídia e semi-interativas criavam uma iconografia histórica da paisagem do Rio. Segundo Motta (2018, p. 223), as instalações repetiam o modelo midiático-informativo dos museus da Língua Portuguesa e do Futebol, constituindo, assim, "novidades mais próximas de uma concepção paternalista-mercantil de 'acessibilidade' de massas - que buscava 'capturar', com mediação 'tecnológica', a atenção de um público que era

\footnotetext{
${ }^{70}$ ImagináRIO (08/2013 - 04/2014), curadoria de Paulo Herkenhoff.
} 
considerado desinteressado e passivo". Na mostra seguinte, o foco se voltou não mais à paisagem carioca, mas à construção social da cidade, aos sujeitos reais que a compõem. Já na terceira mostra da linha, "a curadoria mobilizava tanto a perspectiva histórica quanto o novo foco nos sujeitos sociais 'periféricos' ou "subalternos"” (MOTTA, 2018, p. 224). Além disso, a curadoria, desta vez, no lugar das instalações multimídia, investia mais em obras de arte contemporânea e no dispositivo da contaminação.

Essa mudança de tom, em relação a Rio de Imagens e Do Valongo à Favela, foi percebida e mencionada por um dos presentes na palestra de Clarissa Diniz em Arte: História, Crítica e Curadoria (MAR, 2014, vídeo 3). Quanto a isto, Diniz responde que Rio de Imagens foi criada em um momento em que o MAR ainda estava construindo o seu olhar sobre o Rio. Assim, a proposta da exposição era mostrar o imaginário do Rio feito por um olhar de fora, um olhar construído e elitista, que não necessariamente vê a realidade.

Em resumo, tanto o projeto educativo quanto o programa curatorial do museu (envolvendo suas 3 linhas curatoriais iniciais: Rio de Janeiro, Modernidades e Arte Contemporânea "emergente") procuravam questionar o elitismo dos códigos "artísticos" que a própria instituição museológica representava, exibia e legitimava (contrastando e abordando tais códigos a partir da perspectiva de acessibilidade, de massas, da cultura visual). $\mathrm{O}$ programa curatorial do museu também problematizou, de modo aberto, o etnocentrismo (ou o eurocentrismo) excludente de grande parte da produção artística estabelecida no "circuito de arte". (MOTTA, 2018, p. 225).

O MAR, ao incorporar a produção dos coletivos, levou-a a outro nível. Quando essa produção saiu do campo midiático para entrar no museu, a visibilidade que ela gerava para os movimentos sociais deixou de ter "o efeito de pressão" para constituir uma documentação. Em contrapartida, segundo Motta (2018, p. 228), “abria-se, em chave institucional, um espaço para reflexão e debate críticos". Ao trazer a produção dos coletivos para a galeria, o MAR fazia reverberar a atuação e as demandas dos movimentos por moradia.

Reciprocamente, no conjunto, o exercício curatorial se apropriava da candente problemática urbana trazida pelos trabalhos e documentos trazidos pelos coletivos - "virando o jogo", discursiva ou performativamente, dos questionamentos acerca da ação gentrificadora do museu, no contexto, todavia real, do Porto Maravilha. (MOTTA, 2018, p. 229, grifo do autor). 


\subsection{5}

\section{Por dentro da onda: Brechas}

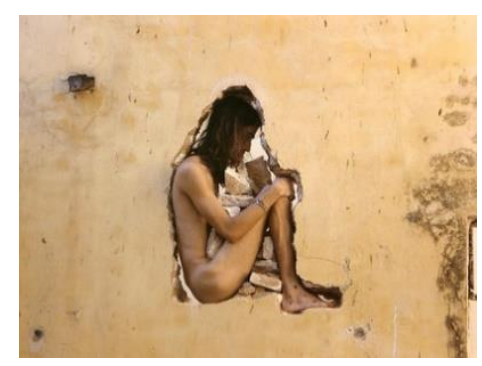

Figura 12: Detalhe de Ação 3

- Yuri Firmeza

Motta (2018, p. 239) finaliza sua tese de maneira bastante pessimista frente ao novo governo pós-impeachment, afirmando que ele radicalizou o quadro de guerra social aberta que teve início em 2014, desencadeando "um processo brutal de regressão: extinção dos direitos do trabalho, ataques a lideranças políticas e rotinização do genocídio". Talvez na data da defesa, em maio de 2018, o cenário sombrio da eleição presidencial daquele ano ainda não estivesse tão delineado.

A perspectiva negativa do autor em relação ao MAR se alinha com a de outros críticos que pensam na atuação de obras de arte, de artistas ou coletivos, e até mesmo das práticas dentro do próprio museu como algo que tem um alcance muito além do que aquele elemento se propõe. A área de atuação do museu, o campo discursivo, possui seus limites, mas também tem potências. É importante lembrar que, em 2018, foi eleito para presidência um candidato da extrema direita, cuja principal estratégia de campanha política foi supostamente a disseminação de notícias falsas, uma estratégia discursiva (cf. BARRAGÁN, 2018; PADUAN \& SILVA, 2020). Portanto, não se deve desconsiderar o potencial das estratégias discursivas.

Além disso, Motta (2018), ao trabalhar com a perspectiva gramsciana, acaba se prendendo à miopia que não permite que se visualize outros cenários possíveis, conforme sinaliza Walsh (2016).

O título do subcapítulo 4.1 é uma referência à fala de Hugo Oliveira, anteriormente à frente do projeto Vizinhos do MAR, no evento \#MARé (MAR, 2020, evento 1). Morador do Morro da Providência e participante do projeto da Galeria Providência, ele afirma que aprendeu a "surfar por dentro da onda", isto é, a agir por dentro do sistema, sem se retirar dele. Ressalta ainda que, como "negro e favelado", é importante para ele ocupar este tipo de espaço, historicamente 
excludente. No ano de 2020, conforme anúncio no site e nas redes do MAR, Oliveira assumiu a coordenação da Escola do Olhar. Em nota publicada com o anúncio, assegurou que sua missão é "estimular a descolonização do corpo institucional e de manter a vocação do museu para dialogar com questões como as relações étnico-raciais e direitos humanos".

No evento citado, Oliveira demonstra uma visão questionadora sobre o MAR e faz até mesmo algumas críticas diretas à instituição, como ao fato de que o museu se coloca como o centro em sua relação com os Vizinhos, não realizando projetos dentro da Providência, por exemplo. Diz ele: "Vizinho visita vizinho, mas não vejo o MAR indo até a Providência”. Portanto, em nenhum momento ele se mostra doutrinado pelos interesses institucionais. Pelo contrário, sua disposição para "surfar por dentro da onda" expressa a sua habilidade em perceber espaços, brechas (WALSH, 2016), para insurgir.

Perspectivas similares podem ser evidenciadas por parte de alguns participantes de coletivos que concordaram em expor no MAR ou ainda artistas em geral que se engajaram no debate sobre entrar ou não no museu. Durante a palestra Arte: História, Crítica e Curadoria (MAR, 2014, vídeo 3), Diniz lê alguns trechos de artigos e textos trocados por e-mail falando sobre a exposição $O$ Abrigo e o Terreno, a obra Poética do Dissenso e a participação de coletivos na mostra. Um deles, assinado por Mariana Cavalcante, fala especificamente sobre ver o museu como uma brecha, a partir da qual pode se tornar visível a própria política de remoções.

A coisa já rolou, desapropriações, despejos, limpeza social. O museu está lá, será aberto com ou sem a exposição sobre os movimentos sociais, não faríamos nenhuma falta. Por que não entrar lá e falar sobre o que tudo aquilo se trata? Fazer com que as pessoas encarem essa realidade de frente, ver quanto de cinismo é necessário para que as pessoas simplesmente finjam que não entenderam a mensagem? Esse museu não precisa de artista-ativista para se legitimar, não mesmo. O Paes não se daria ao trabalho de fazer essa encomenda. Mas a brecha surgiu. Melhor ignorar e não participar ou aproveitar e se manifestar? (texto assinado por Mariana Cavalcante, lido por Diniz em MAR, 2014, vídeo 3).

Fabiane Borges, uma das participantes dos coletivos que criaram a Poética do Dissenso, em uma entrevista na qual comenta sobre a obra e sobre o MAR em si, afirma que a entrada da arte dos coletivos no museu pode ser vista como uma maneira de resguardar a memória da atuação junto aos movimentos sociais por moradia. A produção destes grupos era até então documentada e guardada na 
internet, sem uma garantia real de preservação. Assim, fazer com que essa produção se tornasse acervo de um museu constituiu uma alternativa para que a memória fosse preservada e até mesmo futuramente revisitada.

A gente vive numa era de pouca memória, e a internet, os sistemas de busca ou as redes sociais, contribuem para essa falta de densidade do que se lembra. [...] Parece que a memória tem um preço, e o meu preço pessoal, foi ter que ter encarado os ativistas em frente ao museu no dia da sua inauguração, quando fizemos a instalação audiovisual "Poéticas do Dissenso". Parecia uma incoerência, um paradoxo, uma contradição. Estávamos dentro e fora do museu naquele momento, e a única coisa que tínhamos para colocar para jogo era a força das obras, a memória dessas ações. Para gente como nós, que gosta das coisas abertas, livres, rueiras, realmente é perturbador passar por situações onde os ativistas, o povo que grita e resiste está do outro lado, do que o que a gente está. [...] Eu realmente acredito que esse processo vivido por uma rede de companheiros de estrada, esses anos todos dedicados a rua, deve ser preservado em algum lugar, se esse lugar é o MAR, que seja, nada pode nos paralisar, ou pelo menos não deveria. (Fabiane Borges em entrevista, BORGES \& LIMA, 2015, p. 6).

Borges assinala ainda que, além de precisarem ser preservadas, as obras possuem uma potência discursiva. A discussão proposta por elas precisa ser propagada.

Se encerramos nosso trabalho, enterrando-o no mausoléu branco, o que esperamos é que esses fantasmas atordoem as novas gerações e as impregnem de inspiração e desassossego. Essa é minha aposta pelo menos, eu não nego que houve sim uma espécie de traição, ao que não pode entrar no museu gentrificado, burocrático e hierárquico, mas a aposta é no produto que a gente colocou lá dentro. (Fabiane Borges em entrevista, BORGES \& LIMA, 2015, p. 5).

Conforme sinaliza Walsh (2016), as brechas se encontram dentro da própria colonialidade - dentro do "mausoléu". Dizer que há uma brecha é não aceitar a derrota pela gentrificação ou pela privatização, é afirmar que ainda há o que fazer, é visibilizar espaços de insurgência. Nesse sentido, buscou-se aqui evidenciar como esse instrumento hegemônico que é o museu pode ser transformado a partir das fissuras, de pequenas aberturas como uma exposição que busca pensar ele próprio criticamente.

\section{Lista de vídeos e eventos}

[vídeo 1] MUSEU DE ARTE DO RIO. Conversa de Galeria com Ernesto Neto - Especial de encerramento O Abrigo e o Terreno. 05 ago. 2013. (30m37s). Disponível em: https://youtu.be/VNT0GOZv1GE. Acesso em 29 out. 2019.

[evento 1] MUSEU DE ARTE DO RIO. \#MARé. Rio de Janeiro: Museu de Arte do Rio (MAR), 12 fev. 2020. 
[vídeo 2] MUSEU DE ARTE DO RIO. Palestra com Paulo Herkenhoff - Arte: História, Crítica e Curadoria (PUC/SP). 08 dez. 2014. (1h29m02s). Disponível em: https://youtu.be/xlsa3sPTZ8. Acesso em: 20 mar. 2020.

[vídeo 3] MUSEU DE ARTE DO RIO. Palestra com Clarissa Diniz - Arte: História, Crítica e Curadoria (PUC/SP). 12 dez. 2014. (1h13m57s). Disponível em: https://youtu.be/KPW01N5rDcw. Acesso em: 21 mar. 2020.

[vídeo 4] MUSEU DE ARTE DO RIO. Debate de encerramento da exposição O Abrigo e o Terreno. 06 ago. 2013. (02h05m01s). Disponível em: https://youtu.be/ccqO_ywk1cY. Acesso em: 20 nov. 2019.

[vídeo 5] MUSEU DE ARTE DO RIO. Seminário "O Terceiro Setor na Gestão da Cultura" Pt. 1. 29 mar. 2017. (2h38m52s). Disponível em: https://youtu.be/ZRdTNra3MpU. Acesso em: 15 fev. 2020.

[vídeo 6] MUSEU DE ARTE DO RIO. Seminário “O Terceiro Setor na Gestão da Cultura" Pt. 3. 29 mar. 2017. (2h09m46s). Disponível em: https://youtu.be/0kDLJpX4ymY. Acesso em: 17 fev. 2020

[vídeo 7] MUSEU DE ARTE DO RIO. Seminário "O Terceiro Setor na Gestão da Cultura"| Pt. 2. 29 mar. 2017. (2h07m21s). Disponível em: https://youtu.be/GsLHHZcDcRE. Acesso em: 16 fev. 2020.

\section{2 \\ Me ensina a olhar? - A Escola do Olhar e a interculturalidade no MAR - Dja Guata Porã}

Diego não conhecia o mar. O pai [...] levou-o para que descobrisse o mar. [...] E foi tanta a imensidão do mar, e tanto seu fulgor, que o menino ficou mudo de beleza. E quando finalmente conseguiu falar, tremendo, gaguejando, pediu ao pai: — Me ajuda a olhar!

(Galeano)

Segundo Pucu et al. (2019), o MAR é composto a partir de três eixos: a Escola do Olhar, o Programa de Exposições e a Coleção. Isso significa que, para além de um museu com um setor educativo, esta é uma instituição vinculada diretamente à educação.

O Museu de Arte do Rio não tem um programa educativo, tem uma escola. Que os outros museus nos perdoem, mas, para o MAR, educação é tão fundamental que um dos seus eixos estruturantes - ao lado do Programa de Exposições e da Coleção MAR - é a Escola do Olhar. Uma escola livre, gratuita, revolucionária, que abraça e promove a diversidade em todas as suas atividades; que recebe seus públicos, sejam bebês, crianças, jovens ou adultos, com a mesma seriedade, criatividade e paixão. (GRADIM, 2019, p. 3) . $^{71}$

Gleyce Heitor, que trabalhou como coordenadora pedagógica do museu, na palestra Arte: História, Crítica e Curadoria (MAR, 2014, vídeo 8), explica como

\footnotetext{
${ }^{71}$ GRADIM, C. Viva os educadores do MAR. In: PUCU, I.; NICHOLS, N.; ZACA, R. (org.)
} Dispositivos Artístico-Pedagógicos. Rio de Janeiro: Instituto Odeon, 2019. 
foi estruturado o projeto da Escola do Olhar. Segundo ela, a concepção de escola, anunciada no próprio nome, ultrapassa a noção de um setor educativo. A ideia é lidar com a formação de um modo geral, conjugando a educação formal, não formal e traçando uma ligação efetiva entre o público e a arte. Ressalta que a arquitetura do museu já é pensada no sentido de colocar o corpo no diálogo entre a educação e a arte. Assinala ainda que, em muitas instituições, o setor educativo se restringe ao objetivo de atrair público e convencê-lo do discurso proposto pela exposição. Mas o MAR trabalha em uma perspectiva que vai além disso.

A Escola do Olhar é um polo de pensamento e de formação permanente, voltado especialmente para a prática e a reflexão a partir das relações entre educação e arte. Suas ações buscam aprofundar a dimensão pública do museu, bem como colocar em debate as questões urgentes dos campos da arte e da cultura na contemporaneidade. (PUCU et al., 2019, p. 106).

Em relação ao nome "Escola do Olhar", Heitor (MAR, 2014, vídeo 8) afirma que ele parte não da concepção de existir uma forma certa de olhar e perceber uma autonomia da arte e do objeto, mas em identificar possíveis conexões de variadas ordens. Assim, as formações e as visitas são trabalhadas no sentido de provocar essas conexões. Ainda que o olhar possa se voltar à própria obra, ou ao processo artístico, a perspectiva de "olhar" adotada pela Escola do Olhar se refere à construção de olhares através da relação com a arte, não propriamente a "ensinar a olhar".

Boing (2016), que integrou a primeira equipe da Escola do Olhar, discute que aprendemos que o olhar é o modo hegemônico de se obter conhecimento. Mas, para ela, há um tipo de educação que o olhar somente não alcança, que precisa ser praticada pelo corpo em suas múltiplas possibilidades de interação com os ambientes e os objetos. Portanto, o museu, como um espaço de educação, pode ser vivenciado "de diferentes e combinadas formas” (BOING, 2016, p. 100).

Em relação à multiplicidade de formas de vivenciar o museu, Boing (2016) destaca um momento, fotografado por uma colega de trabalho, em que dois meninos subiram na obra Morrinho $^{72}$, uma maquete de uma favela colocada na

\footnotetext{
${ }^{72} \mathrm{O}$ Morrinho é uma obra feita pelo Projeto Morrinho, criado a partir de uma iniciativa dos irmãos Cirlan Souza de Oliveira e Maycon de Oliveira. Os dois fizeram uma maquete da favela onde moravam, utilizando tijolos e alguns brinquedos. Outros artistas se juntaram ao projeto e muitas ações surgiram dessa associação, sendo a principal delas a preparação de maquetes do mesmo tipo, representando favelas do Rio. As maquetes são feitas coletivamente por meio de oficinas, em que
} 
área dos pilotis do museu. Segundo ela, não era a primeira vez que crianças, ou o público em geral, expressava o desejo de tocar na obra. E, devido a este desejo, foram colocadas correntes de separação, que os meninos, então, simplesmente ignoraram, agindo como se obra fosse feita exatamente para o que faziam com ela, brincar. A autora questiona: “E quem disse que não foi?” Em sua interpretação, os meninos não estariam agindo na intenção de desobedecer as regras, mas sim experimentando a obra de forma despretensiosa e com o corpo inteiro, exercendo um olhar com todo o corpo.

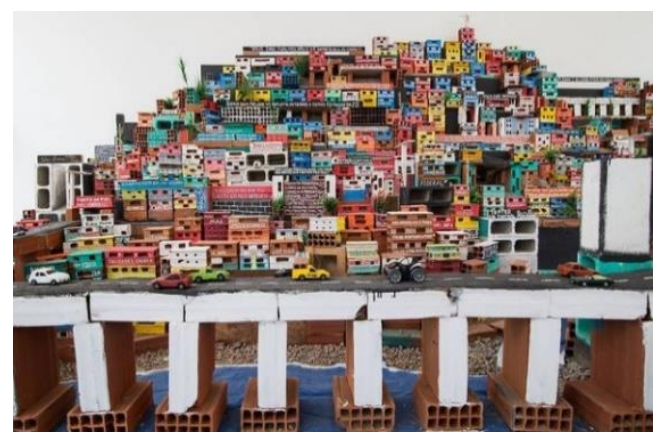

Figura 13: Morrinho - Projeto Morrinho. Foto do Instagram do MAR.

Munhoz et al. (2016), ao analisar as práticas educativas e o currículo do MAR, observam que o que ocorre neste museu é mais um convite a experimentar os sentidos possíveis das obras do que um ensino sobre o que o objeto artístico "quer dizer". Os autores têm como fundamento a teoria de Roland Barthes e focam sua investigação no espaço de interlocução entre público e obra. Assim, a partir da concepção de Barthes, afirmam que a interpretação não deve se dar no sentido de desvendar as intenções do autor - neste caso, o artista -, mas de uma experimentação ou fruição do leitor - ou visitante. Nesse sentido, definindo o currículo como "um dispositivo de produção de sentidos e valores, configurando saberes, espaços, tempos e sujeitos" (MUNHOZ et al., 2016, p. 368), os autores constatam, quanto ao currículo do MAR, que este não se guia por uma lógica escolarizante, mas sim por movimentos experimentais.

Janaina Melo, a primeira gerente da Escola do Olhar, em participação no evento \#MARé (MAR, 2020, evento 1), afirma que o traço fundamental do MAR é

não só é ensinada a técnica material de produção, como também são discutidos os elementos estéticos que compõem o cenário da favela e também seus aspectos culturais. A maquete Morrinho, no MAR, foi exibida pela primeira vez em $O$ Abrigo e o Terreno e depois transferida para os pilotis do térreo, onde se encontra até o momento e é considerada um ícone do museu. 
a sua busca por construir espaços de discussão no lugar de espaços de aprendizagem no sentido transmissivo, além de ter como alicerce a diversidade epistemológica.

A respeito de uma posição de ordem contra-hegemônica do museu, Heitor (MAR, 2014, vídeo 8) afirma que, apesar de o MAR ser, então, um museu novo, há de se considerar toda a história da instituição museu que o precede. Sinaliza ainda que existem empresas por trás e, assim, apesar de as exposições proporem um diálogo transgressor, é uma transgressão que tem limites. Para ela, quem costuma ocupar o lugar de convite à transgressão são o artista e o educador.

Boing (2016), voltando-se ao trabalho dos educadores do MAR, explica que existem muitas denominações para este tipo de profissional e que o nome de escolha reflete as concepções da instituição ou do próprio profissional. Eles podem ser chamados de "guias", "monitores", "arte-educadores" ou ainda, como é a preferência do MAR, "educadores". A autora também sinaliza que o trabalho destes profissionais é chamado na instituição de "mediação cultural" e trata-se de uma prática que busca, indo além da mera explicação sobre as obras expostas, engajar o público com as mesmas.

Conforme explicita Heitor (MAR, 2014, vídeo 8), a Escola do Olhar trabalha com cinco linhas de atuação: 1) comunidade, que tem como principal projeto o Vizinhos do MAR; 2) visitas educativas, que constituem visitas agendadas para grupos, não necessariamente escolares; 3) diálogo com as universidades, que se dá através do programa MAR na Academia; 4) formação com os professores, em uma ligação com as escolas municipais; e 5) a própria Escola do Olhar em um sentido mais restrito.

As visitas agendadas com a Escola do Olhar, de acordo com Pucu et al. (2019), podem ter duração de até duas horas e podem atender a grupos de até 44 pessoas. Elas são compostas por três etapas centrais: a pré-visita e preparação, na qual quem faz o agendamento escolhe o eixo conceitual e explica as expectativas para a visita; a visita em si; e o relatório, que é produzido pelo educador responsável pela visita ao seu término. 
Afirma ainda Pucu (2019) ${ }^{73}$ que os eixos conceituais das ações da Escola do Olhar giram em torno da frase "Você está no Museu de Arte do Rio", que está nas paredes do museu. Assim, pode-se optar em uma visita por um dos quatro eixos: "Meu corpo no museu", que foca no primeiro elemento da frase, "você"; "Guardar para lembrar", que se volta ao segundo elemento, o "museu"; "Práticas artísticas contemporâneas", que enfatiza o elemento "arte"; e "Vejo o Rio", que se concentra no último elemento, a cidade do Rio de Janeiro, trazendo uma leitura de sua história por um viés decolonial. Como afirma Boing (2016), quem procura o museu para o agendamento pode escolher um dos eixos conforme o interesse que desencadeou a visita. Cada eixo possui uma metodologia de visita correspondente e busca, à sua maneira, explorar os conteúdos das mostras do MAR.

Segundo Boing (2016), embora a principal responsabilidade dos educadores seja o atendimento ao público agendado, eles lidam também com o público espontâneo dentro do espaço expositivo. Existem ainda alguns eventos, que geralmente ocorrem aos fins de semana, direcionados a este público como a Conversa de Galeria e as Atividades Educativas. No primeiro, o educador propõe uma conversa dentro da galeria sobre a exposição ou algumas obras específicas. No segundo, o educador convida o público para experimentações a partir da temática das exposições. Além das visitas agendadas, o trabalho do educador consiste em ficar dentro das exposições, mantendo um contato com o público e assegurando a preservação das obras, ou planejar e pesquisar sobre sua prática. Diz ainda a autora que, às segundas-feiras, dia em que o museu fecha para o público, ocorrem atividades de formação para os educadores.

Quanto à relação do museu com a comunidade, no projeto Vizinhos, Heitor (MAR, 2014, vídeo 8) indica que a ideia não é apenas manter uma boa relação com as famílias do entorno, mas também com os comerciantes e os artistas locais. Os Vizinhos fazem uma carteirinha do museu, com a qual têm acesso gratuito às exposições, em qualquer dia da semana. Esse projeto teve início com o Café com Vizinhos, um café da manhã oferecido na Escola do Olhar. Segundo Heitor, a princípio, era apenas uma maneira que o museu encontrou para ouvir a população local, mas, depois, se tornou um programa maior, dentro do qual foi também

${ }^{73}$ PUCU, I. Objetos-limite e outras práticas experimentais de educação e arte no MAR. In: PUCU, I.; NICHOLS, N.; ZACA, R. (org.). Dispositivos Artístico-Pedagógicos. Rio de Janeiro: Instituto Odeon, 2019. 
criado o programa Ofícios e Saberes, no qual um dos Vizinhos realiza uma oficina na Escola, e a Batalha do Conhecimento, que consiste em uma batalha de rap freestyle ${ }^{74}$, em que um rapper compete com outro improvisando letras a partir do tema da exposição.

De acordo com Boing (2016), além dos cursos e dos cafés da manhã, que acontecem todo primeiro sábado do mês, como parte do programa Vizinhos do $M A R$, o museu também convida alguns representantes da comunidade local para conduzir o evento Conversa de Galeria.

Quanto à relação do MAR com as crianças, Heitor (MAR, 2014, vídeo 8) afirma que elas não são uma preocupação apenas da Escola do Olhar, como são consideradas desde a organização espacial das exposições. Cita como exemplo o fato de a exposição Josephine Baker e Le Corbusier no Rio ter uma sala toda fechada, porque trazia o tema do corpo da mulher e da travesti. Nessa sala, havia muitas imagens de corpos nus. Para ela, é uma questão que poderia ser trabalhada com qualquer público, todavia, algumas negociações são necessárias, se o objetivo é minimamente alcançar essa audiência.

Quanto à formação dos educadores do museu, Zacca $(2019)^{75}$, em uma referência a Paulo Freire, destaca que a formação parte do reconhecimento da própria incompletude e que, a partir dela, algo toma forma, mas nunca em solidão, sempre coletivamente. É necessário destacar que há na publicação Dispositivos Artístico-Pedagógicos (PUCU et al., 2019) muitas referências a Paulo Freire, significativamente mais do que a qualquer outro autor, o que possivelmente justifica ele ter sido o único citado como referência no segundo questionário aplicado pelo GEPEMCI, conforme análise no terceiro capítulo desta dissertação.

Tendo caracterizado a Escola do Olhar e o projeto educacional do MAR de maneira abrangente, agora será possível focar em dois pontos específicos: o atendimento a crianças e o programa Vizinhos do MAR. Por fim, a mostra Dja Guata Porã será apresentada para ilustrar não apenas uma maneira diferente de pensar a educação em museus, mas um modo outro de fazer museu.

\footnotetext{
${ }^{74} \mathrm{O}$ rap freestyle, que literalmente significa "rap em estilo livre", é um tipo de rap caracterizado pela letra improvisada no momento, seguindo uma batida já pronta. Nas batalhas, um rapper desafia o outro e vence quem demonstrar maior criatividade e rapidez para a improvisação.

${ }^{75}$ ZACCA, R. A produção da diferença: arte-educação e democracia. In: PUCU, I.; NICHOLS, N.; ZACA, R. (org.). Dispositivos Artístico-Pedagógicos. Rio de Janeiro: Instituto Odeon, 2019.
} 


\subsection{1 \\ Todos a bordo! - Um MAR de crianças, bebês e de quem mais quiser nadar}

Era 2019 e a exposição $O$ Rio do Samba sairia de cartaz em pouco tempo. Aproveitei uma sexta-feira em uma semana menos atribulada do mestrado e fui ver a mostra. Quando cheguei ao MAR, encontrei um grupo grande de crianças, que aparentavam ter por volta de quatro ou cinco anos, usando uniforme escolar. Elas estavam lanchando nos pilotis, sob a observação de algumas professoras. Comprei meu ingresso e entrei no elevador da Escola do Olhar. Subiram junto comigo duas outras visitantes, mulheres, que deviam ter por volta de quarenta anos de idade, e um educador do museu, jovem, que não devia ter mais de vinte anos. As mulheres estavam surpresas pelo fato de a escola ter agendado uma visita ao museu para um grupo de crianças "tão pequenininhas". O educador, então, entrou na conversa, dizendo que isso não era tão incomum no MAR e que, na verdade, era algo muito importante. "Mas elas entendem alguma coisa do que estão vendo?", questionou uma das visitantes. O educador respondeu: "A gente acha que elas não entendem, mas elas entendem sim, só que de um jeito diferente do que a gente entende. E essas experiências que a gente vive nessa idade ficam na gente. Se elas tiverem uma experiência legal com museu e com arte, elas vão ter uma relação de afeto com isso pelo resto da vida"76.

Depois, enquanto eu passeava pela exposição, vi o primeiro grupo de crianças entrando - elas foram divididas em dois grupos. Este era o grupo de crianças mais novas - acredito que de quatro anos. Estavam acompanhadas por duas professoras e um educador, que segurava um fantoche de Heitor dos Prazeres, sambista e pintor que tinha algumas de suas obras expostas na mostra. Depois de entrar na sala, passando por uma instalação em que as crianças eram convidadas a sambar, o educador parou em frente a uma das obras do artista, mostrou o fantoche e apresentou Heitor para o grupo. A partir daí, quem conduziu as crianças pela exposição foi Heitor, a quem as crianças ouviam com atenção e interagiam, fazendo comentários e perguntas.

"Mas você morava aí?"

"A sua roupa é igual à do homem no desenho."

\footnotetext{
${ }^{76}$ Reproduzo aqui livremente o que me lembro das falas e da visita de maneira geral.
} 
Em seguida, entrou o segundo grupo, com as crianças maiores - creio que de cinco anos. Elas eram acompanhadas por uma professora, que seguia atrás do grupo, e um educador, que ia na frente, segurando um pandeiro. Ele fazia a transição entre as obras e as salas tocando o instrumento e improvisando um samba, que tinha a ver com a exposição como um todo, com as obras ou com as falas das crianças.

O clima geral da visita era de muito barulho e algazarra, algo que rompe diretamente com as formas tradicionais de se estar no museu e até mesmo com a disciplina escolar.

Como foi observado na análise dos questionários do GEPEMCI, no terceiro capítulo desta dissertação, crianças em idade de educação infantil (de 0 a 5 anos) estão entre as audiências menos contempladas com programações específicas em espaços museais. Além disso, a grande maioria das instituições alegou não possuir iniciativas para atração deste público. Estes fatos indicam uma exclusão deste setor da sociedade. Entretanto, o MAR teve respostas que destoaram da maioria.

Carvalho et al. (2020) procuraram, a partir da investigação institucional do GEPEMCI, programações voltadas especificamente para o público infantil espontâneo, tendo como foco crianças de zero a cinco anos. Através das informações coletadas pelo grupo no questionário aplicado em 2015, as autoras puderam notar que o MAR estava entre as oito instituições que constituíam exceções que declararam receber crianças entre zero e três anos com frequência alta, diante do quadro geral de 85 respondentes. A fim de conhecer como se dá o atendimento a este público, as autoras fizeram uma análise do Bebês no MAR, evento mensal que acontece no museu com a participação de bebês e suas famílias.

Santos (2017 apud Carvalho et al., 2020) destaca que os museus, enquanto espaços historicamente elitizados, ainda são muito resistentes para acolher os bebês. A autora defende que, apesar de o recebimento desse público poder ser considerado desafiador, o museu constitui um espaço importante para o encontro entre adultos, crianças e acervo, que é necessário confiar na capacidade das crianças e que criar condições para receber este público é ser inclusivo. "As ações que aproximam os bebês do cotidiano do museu agem diretamente no campo da acessibilidade social e simbólica desses espaços" (SANTOS, 2017 apud CARVALHO et al., 2020, p. 4). 
Carvalho et al. (2020) observaram a atividade Bebês no MAR ocorrida em 23 de junho de 2018, quando compareceram cerca de 50 bebês acompanhados de suas famílias, que foram divididos em dois grupos. Na época, estava em cartaz a exposição $O$ Rio do Samba, a qual a atividade se articulava, dedicando-se à musicalidade e à sensorialidade. As autoras apontam que a atividade era gratuita e tinha como alvo bebês de zero a dois anos.

O evento começava no terraço do museu, onde os educadores esperavam os grupos que subiam pouco a pouco pelos elevadores da Escola do Olhar. As autoras verificam que esta chegada era um tanto lenta. Uma vez que os bebês chegavam acompanhados de pelo menos um familiar, mas, alguns vinham com grupos de até quatro pessoas, além de precisarem andar com seus carrinhos e bolsas, foram necessárias muitas viagens de elevador até que todo o grupo chegasse ao terraço. Ao chegarem, eram recebidos em ritmo de samba pelos educadores, que tocavam instrumentos musicais, cantavam e dançavam. As autoras percebem que o público espontâneo, que desconhecia a atividade, observava com um estranhamento curioso.

Todo o passeio é conduzido ao som de música, como um bloco de carnaval, no qual os educadores vão na frente, "puxando", e as famílias, atrás. No centro da última sala, há um grande tapete colorido estendido e, sobre ele, alguns instrumentos, como pandeiros, e outros objetos, como bambolês com fitinhas coloridas. Neste espaço, acontece uma roda de samba com os bebês. As autoras observam que os bebês interagiam entre si, com a música e com os instrumentos. Segundo Carvalho et al. (2020, p. 7), "o movimento de braços, os olhares, a experimentação dos objetos e a interação com outros bebês indicavam que eles exploravam tudo o que era oferecido". Em seguida, se dava o fechamento da atividade, ainda em formato de bloco.

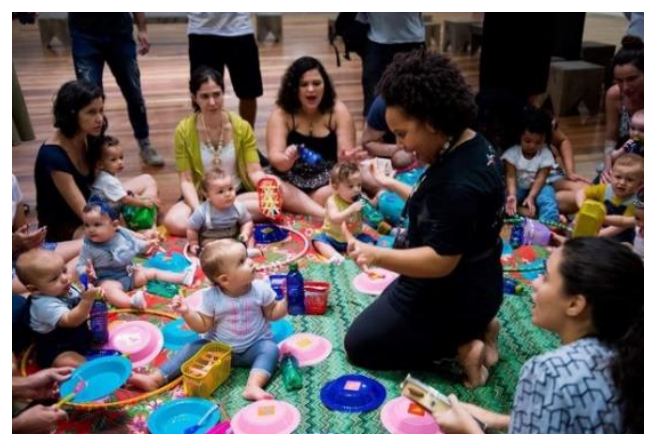

Figura 14: Registro da atividade Bebês no $M A R, 2019$. Foto do Instagram do MAR. 
Para Carvalho et al. (2020), a experiência observada indica que é possível abrir o museu para bebês e famílias. De acordo com as autoras, a maneira como a atividade foi conduzida evidenciou que os profissionais tiveram um efetivo planejamento e qualificação prévios. Assim, concluem que o MAR teve êxito no oferecimento de acessibilidade social e simbólica para esta camada da sociedade.

Em sua tese, Lopes (2019) se volta à questão da relação entre o público da educação infantil e museus, observando museus de tipologias diversas na cidade do Rio de Janeiro. A partir de uma análise dos questionários do GEPEMCI, Lopes (2019) selecionou três museus de tipologias diferentes: de arte, o MAR, de ciência, a Casa da Ciência da UFRJ e de história, o Museu Casa de Rui Barbosa. Para a seleção, levou em consideração a oferta de programação específica para turmas de educação infantil e a frequência do público infantil escolar.

Lopes (2019), em um estudo piloto, obteve resultados que mostram que os equipamentos culturais são distribuídos de forma desigual na cidade do Rio de Janeiro. As áreas da cidade com maior número de crianças são as que possuem menos equipamentos culturais. Além disso, atestou que o público infantil é considerado com pouca relevância no planejamento das atividades de maneira geral. Com base em Carvalho et al. (2017), afirma que tanto a questão da distribuição de equipamentos culturais quanto a de oferta de programação para o público infantil são questões essenciais para se considerar a fim de "reconhecer as crianças como cidadãs de direito, e as instituições culturais como espaços democráticos" (LOPES, 2019, p. 69).

Conforme destaca Lopes (2019), desde 2009, a pré-escola, que compreende o segmento de crianças de 4 e 5 anos de idade, é parte da educação básica obrigatória. Entretanto, este segmento não vem sendo considerado nas programações de equipamentos culturais, ainda que as visitas escolares componham uma parte significativa de sua audiência, como assinala Carvalho (2016).

Lopes (2019, p. 97) aponta para algumas barreiras na relação entre o público infantil e os espaços museais:

(i) a persistência da concepção de que visitas com crianças representam um problema para a segurança das coleções e para a tranquilidade das salas; (ii) a inadequação dos espaços para fazer visitas com propostas diversificadas; (iii) a não adaptação das mensagens expositivas; (iv) a escassez na variedade/reformulação dos programas oferecidos; (v) falta de escuta a esse tipo de público; (vi) o 
excessivo peso do espaço expositivo e dos espaços de administração frente aos espaços de serviços educativos.

Fallon e Chavepeyer (2013 apud LOPES, 2019) ressaltam que os museus, por serem monumentos arquitetônicos, são obras de arte em si mesmos e apresentam as mais diversas possibilidades de experimentação. Mais do que o que está em exposição, as crianças podem se sentir fascinadas por elementos como "as grandes escadas, os tetos altos, as perspectivas, a arquitetura imponente, ou até mesmo o murmúrio das vozes ou o silêncio" ou ainda serem atraídas "pelas entradas de ar, pelos extintores, pelos sinais indicativos, dentre inúmeras possibilidades" (LOPES, 2019, p. 110). Nesse sentido, Lopes (2019) destaca a reação de encantamento com a arquitetura do museu e com a vista do terraço como elementos frequentes nas visitas das crianças ao MAR.

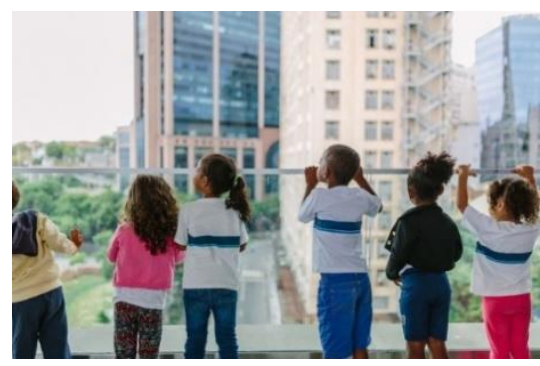

Figura 15: Registro de crianças observando a Praça Mauá, a partir do mirante da Escola do Olhar. Foto do Instagram do MAR.

Lopes (2019) realizou, ao longo do ano de 2017, observações de atividades realizadas com turmas de educação infantil, dentro das ações do projeto Visitas Educativas, um programa de mediação oferecido para públicos escolares e não escolares com agendamento prévio. No período de sua pesquisa de campo, havia três exposições em cartaz: Dja Guata Porã ; Feito Poeira ao Vento; e Dentro ${ }^{77}$.

A autora indica que o MAR não possui um programa ou projeto particularmente voltado ao público de educação infantil, sendo este inserido dentro do programa de Visitas Educativas. Nesse programa, ao agendar a visita, o professor escolhe um entre os quatro eixos temáticos, que se relacionam diretamente aos principais temas de interesse do museu. A partir do eixo escolhido, a visita pode atravessar diferentes exposições que estejam em cartaz ao

\footnotetext{
${ }^{77}$ Feito poeira ao vento: Fotografia na Coleção MAR (08/2017 - 08/2018), curadoria de Evandro Salles.

Dentro: Programa Sala de Encontro (03/2017 - 03/2018), curadoria de Evandro Salles.
} 
mesmo tempo, que geralmente são planejadas pela curadoria de maneira a estabelecer um diálogo entre si.

Lopes (2019, p. 113) verificou nas três instituições investigadas os seguintes elementos:

a realização do trabalho com as crianças nos espaços expositivos junto à presença dos demais públicos, a não utilização de textos como foco das mediações, a busca por adaptações práticas e a tentativa dos mediadores de mostrar que um grupo de crianças no museu não significa um risco à segurança das coleções.

Em relação ao MAR, a autora averiguou que os educadores se valiam de todos os espaços da instituição no trabalho com as crianças, incluindo pátio, terraço, o salão de exposições e até mesmo a reserva técnica. Segundo Lopes (2019, p. 117), as exposições observadas foram planejadas "de forma e altura adequada para que crianças e adultos tivessem acesso e visualização do acervo". A autora destaca ainda que a Gerência de Educação do museu assume como tarefa pensar a acessibilidade de diferentes públicos e, como parte disso, precisa intermediar junto às equipes de curadoria e museologia certos elementos na elaboração das exposições e, caso essa interferência não seja possível, procuram planejar percursos expositivos que abordem a mostra de outra forma.

Temos dois pontos: (i) Desde que o museu abriu experimentamos, de várias formas, a participação da equipe da Gerência de Educação no processo de concepção da exposição. Algumas experiências deram certo, outras nem tanto. Então, não está na mão da Gerência de Educação pensar a exposição, depende muito do curador que vai montar (...). Quando isso acontece [inacessibilidade], a experiência com a exposição tem que se dar de outra maneira. (ii) Não fazemos adaptação como, por exemplo, (até fazemos, mas é eventualmente) um quadro de pintura, não temos aquela pintura em relevo para um visitante com deficiência visual. Procuramos provocar experiências com aquele quadro ou realizamos adaptações no sentido de mapear uma exposição identificando o que é possível ser tocado. Nem todas as obras podem ser tocadas, mas, às vezes, tem uma escultura em que é possível tocar (não por todos os visitantes) e criamos um percurso tátil com alguns visitantes e grupos específicos. (Clarisse, educadora de projetos do MAR, em entrevista para LOPES, 2019, p. 117).

Lopes (2019) ainda assinala que a experimentação, os jogos e as brincadeiras, sobretudo nos espaços expositivos, devem permear diversos momentos da mediação com as crianças em museus e centros culturais, constituindo a sua base. Além disso, Leite (2011 apud LOPES, 2019, p. 119) ressalta que é preciso explorar os diferentes espaços do museu nas atividades com as crianças, "possibilitando e respeitando a rapidez na associação de ideias, os 
interesses pelo acervo e as transgressões caracterizadas pela vontade infantil de soltar o olhar e reverter a ordem das coisas". Destaca também a importância em realizar atividades com as crianças que requeiram concentração e uma observação atenta, engendrando uma diversidade de perspectivas sobre uma mesma mostra. Nesse sentido, a autora observou:

Os amplos espaços expositivos do Museu eram utilizados de forma distintas pelos mediadores que buscavam estimular o prazer, a brincadeira, o movimento e a fantasia, acolhendo a vitalidade das crianças. Influenciados pela temática da fauna brasileira da exposição "Dja Guata Porã", foi possibilitado que as crianças saltassem, pulassem, corressem, rastejassem, engatinhassem, imitassem sons e gestos de diferentes animais, dentre outros movimentos, nas galerias. Na exposição "Dentro", constituída por uma instalação com muito espaço livre, tapetes e objetos acolchoados, os mediadores utilizavam o corpo e um grande tecido azul para propor diferentes movimentos que possibilitavam interagir como o espaço, como rolar, saltar, pular, correr, mergulhar. Na exposição fotográfica "Feito Poeira ao vento", o espaço amplo e as temáticas das obras também proporcionavam essa interação e uma forma diferenciada de ver e estar no museu. Entretanto, essa não foi uma prática adotada pelos educadores (mediador e professores) no momento da visita, que teve como proposta, em sua maior parte, o diálogo e a observação. (LOPES, 2019, p. 117).

De acordo com Lopes (2019), as ações educativas do MAR contam com a participação de todos os funcionários da Gerência de Educação, mas são os educadores que, em dupla, organizam as ações com grupos. Estes dispõem de autonomia em seu planejamento, uma vez que não existe um roteiro de visita que deva ser seguido por todos.

Em entrevista a Lopes (2019), Clarisse, que fazia então parte da equipe de educação do MAR, afirma que as visitas nunca são iguais, uma vez que são planejadas a partir do perfil do grupo, que é traçado através das informações obtidas na pré-visita, isto é, o momento de agendamento. No entanto, os educadores entrevistados por Lopes (2019) informam que o processo tem seus defeitos. Por exemplo, nem sempre o contato com a escola é bem sucedido, o que deixa algumas lacunas no perfil do grupo, e às vezes o tempo disponível não é suficiente para um planejamento adequado.

A autora observou que as estratégias mais utilizadas pelos educadores com os grupos de educação infantil foram o diálogo, a brincadeira e a exploração da diversidade de modos de ocupar o espaço do museu, sendo também frequentes o faz-de-conta, a leitura de imagens e a contação de histórias. Itens de figurino para 
contar histórias, um baú de "tesouros", que guardava colares, sementes, entre outras coisas, instrumentos musicais e outros artifícios também eram empregados.

Quanto à chegada das turmas, Lopes (2019) constatou que o MAR não seguia o "ritual de entrada" típico narrado por Carvalho (2016), no qual as normas de conduta dão início à visita. Pelo contrário, o início das visitas era marcado pelo diálogo e pelo despertar da curiosidade das crianças. Quando a recepção ocorria no terraço, os educadores convidavam as crianças a observarem a paisagem e o teto em formato de onda. Realizavam também brincadeiras que, em sua maioria, faziam referência ao nome mais popularmente conhecido do museu, MAR.

Lopes (2019) teve acesso com seu trabalho de campo a diferentes práticas que atendiam às especificidades do público investigado. Verificou que, no MAR, os educadores consideravam a criança como detentora de autonomia e que poderia, a partir de seu interesse ou curiosidade, determinar a trajetória da visita. Além disso, ao falar com as crianças, os educadores não costumavam fazer uso de uma linguagem infantilizada, cheia de diminutivos, o que demonstra que possuíam uma concepção da criança como sujeito inteiramente competente para experienciar o museu. $\mathrm{O}$ elemento de maior destaque nas visitas observadas em seu trabalho de campo foi a brincadeira, o que evidenciou a concepção dos educadores do MAR da criança enquanto sujeito brincante.

Assim, quanto ao oferecimento de atividades ao público infantil, Lopes (2019) conclui com sua análise que o MAR adota boas práticas para a recepção deste segmento. E, apesar de não oferecer um programa prévio específico para as crianças, a equipe busca atender às suas especificidades, respeitando sua temporalidade e seu modo exploratório. Destaca ainda que o foco das práticas da mediação está nas brincadeiras, o que acaba por constituir um tipo de visitação que rompe com o tradicionalismo do silêncio e da ordem.

As pesquisas apresentadas evidenciam que, no MAR, a criança pequena é bem recebida, ao contrário do contexto observado na pesquisa de Carvalho (2016, p. 68), onde a "criança menorzinha" foi percebida como um dos públicos mais indesejáveis pelos integrantes do setor educativo de outra instituição. O êxito no recebimento de um público amplamente excluído de equipamentos culturais, demonstra um esforço da instituição em operar com os valores público e 
democrático, conforme apontados por Nichols $(2019)^{78}$ e também mencionado pela educadora entrevistada por Lopes (2019).

Quando você traz as crianças para cá, você está atuando diretamente na democratização dos espaços - desde pequenos - porque as pessoas vão ter acesso a esses lugares de cultura, que muitas vezes também são lugares de poder, que excluem. (Clarisse, educadora de projetos, em entrevista para LOPES, 2019, p. 152).

Os benefícios que a presença das crianças pode trazer aos museus também foram destacados pelos entrevistados por Lopes (2019). Trata-se de uma presença que desafia o funcionamento da instituição museu e sua imagem. Assim, tanto as crianças ganham ao estar no museu quanto a própria instituição pode se beneficiar ao receber esta audiência. Segundo Lopes (2019, p. 154), "tornando-o mais vivo, mais barulhento e democrático para diferentes públicos, a presença das crianças pode ajudar a romper com o entendimento de um espaço sacralizado de observação e silêncio".

\subsection{2}

"Para o pobre, isso aqui é uma novidade": Vizinhos do MAR

Munhoz et al. (2016) afirmam que, ao realizar a residência pedagógica no MAR, olhavam com certa suspeita para o projeto Vizinhos do MAR, duvidando do engajamento efetivo da comunidade. No entanto, após presenciarem uma edição do Café com Vizinhos, concluíram que, "ao que parece, a comunidade local, efetivamente, faz do museu um espaço de convivência e se coloca como parte das ações desenvolvidas" (MUNHOZ et al., 2016, p. 377).

O Café é apenas uma das diversas ações do MAR para envolver a população local. Ao observar algumas dessas ações registradas em vídeo e publicadas no canal do museu no YouTube, é possível perceber o quanto a comunidade se apropria da instituição. Além disso, pode-se evidenciar como essas ações conseguem engajar um público que não frequentava museus anteriormente. Nesse sentido, em muitos eventos a própria instituição museu é o tema para discussão. As falas dos Vizinhos demonstram ainda a sua própria opinião sobre o MAR e

${ }^{78}$ NICHOLS, N. A prática educativa é uma ação eminentemente coletiva. In: PUCU, I.; NICHOLS, N.; ZACA, R. (org.). Dispositivos Artístico-Pedagógicos. Rio de Janeiro: Instituto Odeon, 2019. 
sobre as obras do porto, permitindo que se visualizem histórias reais de pessoas que foram negativa ou positivamente afetadas pelas renovações na cidade.

Em um dos vídeos (MAR, 2016, vídeo 9), é possível acompanhar os educadores da Escola do Olhar realizando junto aos Vizinhos do MAR a atividade “Museu é lugar de que?”. Bruna Camargos, então educadora do MAR, dá início convidando a todos os presentes a pensar sobre essa pergunta. Ela vai passando um fio para ligar as pessoas, conforme elas vão falando. Embora alguns falassem da instituição museu de maneira geral, a maioria dos presentes se referiu ao MAR em específico.

Uma senhora, chamada Paula, responde que o museu é o lugar da memória e do conhecimento. Camargos pergunta como ela chegou ao museu, ela diz: "Quando eu vi que era de graça, aí que eu vim mesmo".

O fio vai passando de mão em mão, ligando as pessoas e os relatos. Alguns falam sobre como sua relação com o museu é muito intensa, já tendo sido convidados para falar em eventos. Outros destacam exposições que os encantaram. Entre as palavras e expressões utilizadas para definir o museu é possível destacar: relações, nós, universo coletivo, guardador de memória, lugar de encontro, rede, lugar de reflexão, troca, abertura, experimentação, conexão, um espaço que veio até mim.

Eliane Rosa, vizinha que já realizou uma oficina no MAR, descreve o museu como um lugar de descobertas e redescobertas. E conta que, nesse espaço, conseguiu resgatar um pouco de si mesma, de sua autoestima, após o fim do casamento.

Alguns falam sobre as obras de revitalização da região do museu e da Praça Mauá e o impacto causado na população. Maristela, uma das presentes, afirma que, apesar dos problemas causados a algumas pessoas, a reforma contribuiu para que a região portuária fosse redescoberta. Outra mulher, que se identifica como moradora do Morro da Conceição, conta que antes o lugar era muito sombrio, mas agora os moradores se alegram em utilizar o MAR e o Museu do Amanhã como pontos de referência. Carolina, também moradora do Morro da Conceição, relata que deixava de sair aos finais de semana por medo. Sua filha ficou preocupada quanto aos moradores serem afetados, mas ela vê mais resultados positivos do que negativos em relação à revitalização. Afirma que hoje a área tem maior movimentação e, por isso, é mais segura. 
Algumas pessoas contam que participavam da atividade sem serem Vizinhos. Uma professora afirma que utiliza o museu como um local de trabalho. André Bruno, que diz trabalhar no Museu da República, foi ao MAR com o objetivo de observar a experiência do Vizinhos para possivelmente implantar onde trabalha. Sueli conta que, apesar de não morar na região, se sente "vizinha", porque é sempre bem acolhida.

Gleyce Heitor, então coordenadora pedagógica do museu, afirma, durante a atividade, que "o que vai ser um museu não está dado, ele é feito por quem se apropria dele cotidianamente".

Bruna Camargos finaliza dizendo que, no programa, não usam a palavra “entorno", porque o museu não é o centro. E pergunta se Tia Lúcia, artista e personalidade da Pequena África, gostaria de encerrar. Tia Lúcia fecha o encontro contando uma história.

Tia Lúcia, que faleceu em 2018, foi homenageada pelo MAR na exposição A Pequena África e o MAR de Tia Lúcia. Segundo Pucu \& Camargos (2019a), a artista deixou um legado material e imaterial pela área conhecida como Pequena África e pelos morros do Pinto e da Conceição. As curadoras destacam que a história dos personagens anônimos e populares compõem a história das cidades e, por vezes, dizem muito do que é silenciado pela violência epistemológica do discurso oficial. Nesse sentido, Tia Lúcia constituía parte da história da Pequena África e, depois, também parte da história do MAR, sendo lembrada por muitos membros da equipe como um dos ícones do museu. Ela participava do MAR como protagonista e público, sendo uma integrante do projeto Vizinhos do MAR e também tendo obras suas incorporadas ao acervo.

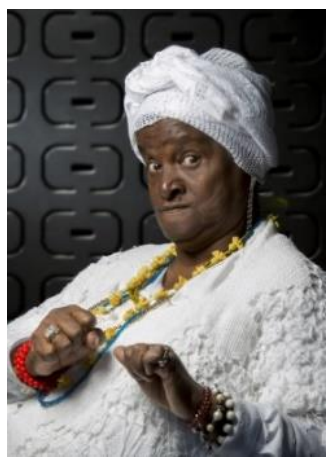

Figura 16: Retrato de Tia Lúcia. Foto: Francisco de Souza.

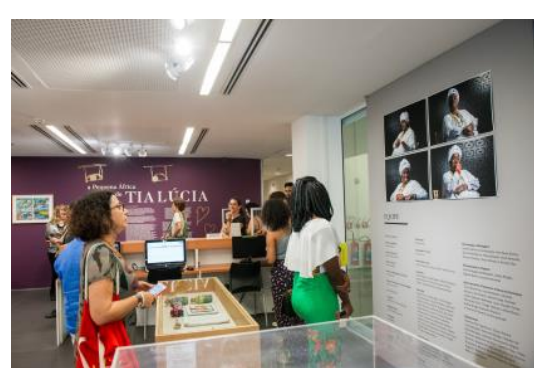

Figura 17: Registro da mostra $A$ Pequena África e o MAR de Tia Lúcia. Foto do Instagram do MAR. 
Quando entrevistada por Bruna Camargos para a edição de 2017 do jornal $O$ Olhar dos Vizinhos no Jornal da Zona, produzido pelos Vizinhos, Tia Lúcia relatou assim seu primeiro encontro com o espaço museal:

Museu era coisa de rico, era muito difícil entrar. Ficava aquela coisa grande bonita, sem ninguém. Eu me sentia acuada em entrar, porque era coisa de gente rica e branca. A primeira vez que fui numa exposição foi sem querer. Eu era professora de catecismo. Quando eu voltava da missa da Candelária com as crianças elas escaparam e entraram no Centro Cultural Banco do Brasil. Eu tive que ir lá dentro buscar elas. [...] O pobre olha mais a cultura do que o rico. O rico já tem tudo, para o pobre isso aqui é uma novidade. Nenhum museu vive só de dizer que ele é lindo, o museu é de todo mundo e, ao mesmo tempo, não é de ninguém, não se pode negar o acesso às pessoas. [...] Agora nós podemos entrar no museu. Aqui no MAR é uma coisa forte, é uma relação de troca, não é só pela beleza, mas é pelo carinho indiscriminado que recebemos aqui. (Tia Lúcia, PUCU \& CAMARGOS, 2019, p. 60)

Em relação ao jornal O Olhar dos Vizinhos no Jornal da Zona, Pucu, que assina o editorial da segunda edição, descreve o projeto como uma produção coletiva dos participantes do Vizinhos do MAR, principalmente daqueles que frequentam o Café com Vizinhos, que constitui, segundo ela, a principal ferramenta do programa. O objetivo do programa é criar "uma plataforma de diálogo, experiência e ação conjunta entre o MAR, moradores, coletivos e instituições da região portuária" (PUCU, 2019, p. 2) ${ }^{79}$. Diz ainda a autora que o Café vem sendo reconhecido como um espaço de diálogo não só entre o museu e seus vizinhos, mas também como um momento de encontro da comunidade com ela mesma, que encontra nele a possibilidade de fortalecer vínculos, de encontrar apoio e de compartilhar as ações e os projetos que vem desenvolvendo na área.

Foi possível evidenciar ainda que o Vizinhos do MAR, além de um espaço de encontro e diálogo da população da área entre si e com o museu, constitui um lugar de valorização da produção artística local, como o caso de Tia Lúcia, e de legitimação e troca de saberes, através do programa Ofícios e Saberes e da Conversa de Galeria.

Eliana Rosa, mineira que mora no Rio há 24 anos, foi uma das convidadas para dar uma oficina dentro do programa Ofícios e Saberes (MAR, 2018, vídeo 10). Em sua oficina, ela ensinou crochê e costura, saberes que são tradicionais em sua família, mas que ela nunca valorizou porque queria ser enfermeira.

${ }^{79}$ PUCU, I. Editorial. In: PUCU, I.; CAMARGOS, B. (Ed.). O Olhar dos Vizinhos no Jornal da Zona. $2^{\mathrm{a}}$ Ed. Rio de Janeiro: Instituto Odeon, nov. 2019. 
Ironicamente, hoje trabalha com este saber, que por muito tempo ficou guardado. Afirma que, na Escola do Olhar, encontrou o apoio para fazer o que, na verdade, sempre quis.

Uma das questões destacadas pelas mulheres que participavam da oficina é que a maioria rejeitava os saberes de corte e costura, porque queria se distanciar de referências ao ambiente doméstico, vistas como dispositivos que subjugam a mulher. Mas muitas viram a aproximação com esse conhecimento como uma forma de encontrar acolhimento em outras mulheres.

Celina Rodrigues, mais conhecida como Mãe Celina de Xangô, mãe de santo e gestora do Centro Cultural Pequena África, foi convidada para falar em um vídeo (MAR, 2019, vídeo 11) sobre uma das obras do museu. Ela escolhe a obra Emblema 85 de Rubem Valentim e afirma: "Não entendo nada de arte, mas baixa um negócio na gente, não é?”.

Outro vídeo (MAR, 2018, vídeo 12) registra o dia em que Mãe Celina foi a convidada do evento Conversa de Galeria. Conforme explica Bruna Camargos, coordenadora da Escola do Olhar, abrindo o evento, o foco da conversa seria o acervo do museu e a exposição $O$ Rio do Samba. Camargos fala que a coordenadora de museologia tirara da reserva técnica duas obras do acervo, uma das quais tinha uma relação de continuidade com algo que estava exposto. Convida então o público para ir ver a série Sete Lendas Africanas da Bahia, de Carybé. A peça que a coordenadora de museologia traria é a xilogravura que estava faltando na exposição. A outra peça era o espelho de Oxum. Explica que a curadoria escolheu fazer uma narrativa sobre o samba, não focando na indústria fonográfica, mas na diáspora africana, a partir de uma experiência da herança africana.

Celina se apresenta, dizendo que não sabe se quem vai falar será a mãe de santo ou a gestora. Afirma: "Muito me orgulha ser vizinha do MAR". Segundo ela, para falar de samba, de jongo ou de capoeira, é preciso falar de candomblé, porque tudo tem início na ancestralidade.

O espelho de Oxum é entregue a Mãe Celina, que o manipula com o uso de luvas. Ela vai, então, construindo uma fala que mescla a sua história como gestora do Centro Cultural Pequena África, com a história da redescoberta do Cais do Valongo e dos objetos encontrados ali, com as outras escavações pelo centro da cidade, que estavam desencobrindo a história silenciada dos escravizados, com os 
saberes do candomblé, com o que o objeto espelho significa na religião e na cultura africana e com a história de Oxum. Passam, então, para ela, o desenho de Carybé, com Exú, que ela olha com admiração. Depois, Ed Gomes, educador do MAR, conta sobre a vida de Carybé, um artista argentino, que veio ao Brasil e se apaixonou pela cultura afro-brasileira e pela tradição do candomblé.

Não são somente pessoas físicas que são Vizinhas do MAR, no vídeo que registra o Café com Vizinhos de encerramento de 2014 (MAR, 2015, vídeo 13), é apresentado um projeto realizado com uma escola Vizinha, o Colégio Vicente Licínio Cardoso, onde funciona o Ginásio Experimental de Arte (GEA). É convidada para falar Roxane Francisca, que desenvolveu um projeto junto aos Vizinhos chamado Foto Nossa de Cada Dia, com as crianças da escola.

Conforme relata Roxane, como parte do projeto, foram realizadas atividades de desenho e fotografia e, depois, foi feita uma instalação. A ideia era que os estudantes documentassem o entorno, trazendo a construção da paisagem ou da memória. Os propósitos do projeto, segundo Roxane, giram em torno não só de levar as crianças ao museu, mas também incentivar os pais a frequentar o espaço.

Após a exibição de um vídeo mostrando o projeto, dois professores são convidados para falar. Uma professora explica que o GEA funciona com os alunos que estão na escola em horário integral. Um professor diz que a primeira visita que a escola fez ao MAR foi na exposição Do Valongo à Favela, que, por ter tocado a todos da escola, constituiu o ponto de partida para o projeto. Relata que pediram autorização aos pais e à escola para fazer saídas com as crianças e explorar o entorno e toda a área da Pequena África. Os alunos coletaram diferentes materiais que pudessem ser utilizados para obras de arte. Esses materiais poderiam ser da natureza, como folhas ou cascas de árvore, ou ainda recicláveis. Por exemplo, foram feitas telas com placas de Eucatex de lojas de móveis que seriam jogadas fora. Essa escolha era para que os alunos percebessem a arte não apenas como algo que se compra. As telas são "dupla face", são duas telas em uma e os trabalhos são coletivos. As crianças fizeram obras a partir delas mesmas, com umas posando para as outras.

A partir da investigação, foi possível observar que o projeto Vizinhos do $M A R$ se configura não apenas como uma possibilidade de diálogo entre o museu e a população local, mas como uma integração efetiva entre instituição e Vizinhos e uma construção coletiva dos muitos sentidos possíveis para o museu. 


\section{2 .3 \\ "O Rio de Janeiro continua índio": Dja Guata Porã, um modo outro de fazer museu}

Vargas et al. (2019) ${ }^{80}$ contam sobre uma atividade feita no Café com Vizinhos, que se voltava à temática de plantas. Os participantes deveriam ao final produzir um desenho e escolher uma palavra que falasse algo sobre sua relação com as plantas. Niara do Sol, indígena, Vizinha do MAR, moradora da Aldeia Vertical $^{81}$ no Morro de São Carlos, que participou anteriormente da exposição Dja Guata Porã, na qual plantou uma horta em um canteiro em frente ao museu, escolheu a palavra "persistência" e explicou:

Quando eu era pequena meu avô dizia "persistência", dizia que nós estávamos vivos porque éramos tão persistentes quanto a natureza. [...] Hoje eu olho para a minha horta Dja Guata Porã e vejo que venceu na persistência, porque quando eu fui morar naquele condomínio, Minha Casa Minha Vida, disseram para mim que não dava para plantar nem mesmo uma roseirinha, uma hortelã... Hoje eu tenho uma mini florestinha lá. Eu levei tudo o que foi plantado aqui no Museu de Arte do Rio na época da exposição que tinha o mesmo nome que minha horta, plantei lá e continuo plantando a cada dia mais. (Niara do Sol, depoimento registrado em PUCU \& CAMARGOS, 2019b, p. 5).

Niara do Sol foi uma das indígenas participantes da exposição Dja Guata Porã. A experiência desta mostra foi relatada na roda de conversa Museus e Democracia Cultural, do Seminário Internacional Desafios dos Museus no Século $X X I$, que tinha como objetivo abordar a possibilidade de se fazer "museus e espaços para imaginar e promover novas estratégias de sociabilidade democrática", sobre "o lugar da instituição na construção de novos modelos democráticos" e as aprendizagens possíveis em "experiências que ultrapassam os limites dos museus" (CAMARGOS et al., 2018, p. 110). Nela, participou Pablo Lafuente, um dos curadores da mostra Dja Guata Porãa que tem como um de seus principais interesses os processos culturais e pedagógicos de natureza colaborativa.

\footnotetext{
${ }^{80}$ VARGAS, A.; CAMARGOS, B.; CYRNE, G. Oficina no Café dos Vizinhos. In: PUCU, I.; CAMARGOS, B. (Ed.). O Olhar dos Vizinhos no Jornal da Zona. $2^{\mathrm{a}}$ Ed. Rio de Janeiro: Instituto Odeon, nov. 2019.

${ }^{81}$ Aldeia Vertical é o nome dado ao bloco do condomínio construído no Morro de São Carlos, como parte do projeto Minha Casa Minha Vida, onde vivem indígenas que foram transferidos da Aldeia Maracanã, a aldeia urbana que fica dentro do terreno do antigo Museu do Índio, ao lado do estádio do Maracanã.
} 
Para Lafuente, projetos como Dja Guata Porã e o próprio projeto da Escola do Olhar podem desencadear o questionamento das relações de hierarquia. Dja Guata Porã foi criada a partir de um diálogo intenso entre culturas indígenas e práticas museológicas, que envolvia, de um lado, as equipes de pesquisa, curadoria e educação do MAR e, de outro, representantes e membros em geral de aldeias indígenas do estado do Rio de Janeiro. Os debates, seminários e demais atividades eram também abertos ao público interessado (CAMARGOS et al., 2018).

Como parte de sua apresentação, Lafuente exibe um vídeo com a documentação do processo de concepção da exposição. No vídeo, uma das curadoras da mostra, Sandra Benites, indígena Guarani, relata sobre a ida da equipe do museu para as aldeias, a fim de conhecer as formas de viver dos grupos indígenas do estado e discutir a exposição. Segundo Benites, "muitas vezes o museu acolhe um objeto sagrado que não faria sentido. Essa exposição foi proposta a partir de um ponto de vista diferente" (CAMARGOS et al., 2018, p. 111). Clarissa Diniz, que também compunha a equipe curatorial, aparece no vídeo afirmando que a exposição buscou "abdicar de muitos dos estereótipos não só em relação ao índio, mas também em relação ao museu, o que se espera de um museu" (CAMARGOS et al., 2018, p. 112).

Entretanto, em relação a uma possível de(s)colonização do museu, Lafuente acredita que a experiência de Dja Guata Porã é limitada.

O museu - as paredes, as janelas, a luz — fica igual. O equipamento determina os processos. Os corpos se movem no espaço. Os protocolos de comportamento são definidos pela casa, e essa casa, o museu, foi herdada no processo de colonização moderna. (fala de Lafuente registrada em CAMARGOS et al., 2018, p. 113).

Não obstante, Lafuente destaca que o MAR se diferencia em certa medida do modelo mais tradicional de museu. Assinala ainda a importância que tem para os povos indígenas a entrada em estruturas de poder, tais como o próprio museu, a academia e a política. Para ele, ocupar estes espaços traz consequências que impactam a indígenas e não indígenas. Em sua visão, Dja Guata Porã não é um modelo a ser seguido, porém é uma experiência que mostra um caminho possível para democratizar o museu e para criar práticas que questionem e desloquem estruturas (CAMARGOS et al, 2018). 
A exposição Dja Guata Porã foi tema de vários artigos escritos, em sua maioria, por pessoas que atuaram diretamente na construção da mostra: Vieira (2019), Benites \& Lafuente (2018), Baker (2018), Guedes et al. (2017). Embora muitas questões, principalmente, as de caráter descritivo, se repitam, cada autor exerce uma reflexão própria sobre o processo. O maior destaque é dado ao engajamento dos participantes indígenas em toda a mostra, desde seu planejamento até o tempo em que permaneceu em exibição.

Vieira (2019), que trabalhava na Escola do Olhar na época de Dja Guata Porã, aponta a histórica relação entre os museus e a colonialidade, assinalando como eles surgiram dentro de um projeto nacionalista e depois se afirmaram em exposições etnográficas "sobre" "o outro", em que o outro, visto como mero objeto, não era engajado no fazer museal. Com as modificações que a teorização sobre os museus foi sofrendo ao longo dos anos, surge a Nova Museologia. Vieira (2019) assinala que a nova abordagem se desdobra já no sentido de repensar o papel do museu, sua relação com o público e com os materiais coletados, e o fazer museal de modo amplo, aproximando a instituição das pessoas e inserindo nela os grupos correspondentes às narrativas propostas.

Para Baker (2018), que atuou como assistente curatorial de Dja Guata Porã, o formato pouco usual de curadoria, montagem e realização desta mostra deslocou o "objeto a ser representado", os indígenas, para a posição de sujeito. A autora destaca que o "outro" geralmente é representado em museus etnográficos, em uma curadoria que não estabelece um diálogo nem uma relação de respeito com sua cultura. Em sua visão, embora a arte contemporânea tenha buscado dar mais visibilidade a culturas não ocidentais, os representantes destas culturas retratadas não costumam ter sua voz ouvida, compondo apenas um objeto para o trabalho do artista ou um tema para uma exposição. Nesse sentido, Dja Guata Porã foi capaz de provocar hierarquias artísticas, curatoriais e pedagógicas tradicionais.

Assim, como também defendem Benites \& Lafuente (2018), curadores da mostra, não importa apenas o que é exibido no espaço museal, mas também a maneira como isso é feito.

Mesmo o modo como se faz importa: se a apresentação de elementos e práticas indígenas acontece sem a negociação com pessoas indígenas, simplesmente se reproduz a violência do processo colonial. (BENITES \& LAFUENTE, 2018, p. 77, tradução nossa). 
Benites \& Lafuente (2018) ressaltam o quanto é raso o conhecimento da população brasileira em geral em relação aos povos originários, também conhecidos como indígenas, e, além disso, o quanto esse conhecimento costuma ser discriminatório, estereotipado e o quanto se dissemina a visão do "índio" como um ser do passado. Um dos objetivos da exposição foi, portanto, mostrar que existem diferentes povos indígenas atualmente no Brasil, em que consistem essas diferenças e como eles vivem na atualidade. Nessa perspectiva, os autores ressaltam a importância em identificar e criar o patrimônio material e imaterial de cada povo, tendo como ponto de partida seu modo de ver o mundo.

Nesse sentido, Vieira (2019) enumera uma série de projetos ocorridos em diferentes museus do Brasil que integravam os povos indígenas nas exposições sobre suas culturas e sua história. Destaca ainda que os grupos indígenas se posicionam longe da dinâmica institucional. Citando James Clifford (2016), Vieira (2019) afirma que o museu pode ser considerado como um espaço de poder fronteiriço, onde diversas negociações podem ocorrer. Ressalta ainda a autora que este espaço é muito mais de conflito do que de neutralidade.

Para Benites \& Lafuente (2018, p. 78, tradução nossa), “o próprio museu é uma construção de território, onde as coisas e as pessoas podem se encontrar ou se desencontrar". Nessa perspectiva, os autores defendem que o museu não precisa ser somente um lugar de seleção, mas também de inclusão.

A narrativa sobre a concepção da exposição, apresentada por Vieira (2019), Benites \& Lafuente (2018), Baker (2018) e Guedes et al. (2017), indica um projeto intercultural, em que não indígenas, querendo se aproximar da cultura indígena, convidam os próprios indígenas para conhecer um de seus modos de obter e construir conhecimento, através de exposição. A interculturalidade é anunciada simbolicamente no nome mesmo da mostra, Dja Guata Porã, que vem do guarani e significa "caminhar bem e caminhar junto".

Os possíveis problemas e potências nas negociações interculturais são o foco de Guedes et al. (2017) em sua análise da experiência de Dja Guata Porã. Para os autores, a participação de indígenas, que encontram no museu um meio de expressão da própria cultura, e de não indígenas, que contribuem com seu conhecimento museológico, é o que confere à mostra seu aspecto intercultural.

Conforme salientam Guedes et al. (2017), a experiência de trazer a questão indígena para o museu não é nova e alguns indígenas até mesmo reconhecem esse 
espaço como uma ferramenta para fazer propagar suas reivindicações. Entretanto, trata-se de uma ferramenta complexa. A maioria dos projetos museais voltados à questão indígena ocorrem em museus etnográficos, alguns dos quais contam com iniciativa ou participação direta de pessoas indígenas. Como exemplo, os autores destacam: o Museu Magüta dos Ticuna, em Benjamin Constant, no Amazonas; o Museu Kuahí, no Oiapoque, Amapá; o Museu Kanindé, no Ceará; o Memorial dos Povos Indígenas, em Brasília; o Museu Índia Vanuíre, em Tupã, São Paulo; e o Museu do Índio, no Rio de Janeiro.

Segundo Guedes et al. (2017), Darcy Ribeiro, fundador do Museu do Índio, afirmava ser necessário mudar a narrativa sobre os indígenas, para tirar do povo brasileiro a visão preconceituosa deles como "fósseis vivos", integrando-os à cultura nacional. Uma das principais inspirações para Dja Guata Porã, de acordo com os autores, foram as experiências de parcerias do Museu do Índio. Neste museu, ocorreu em 2001 a primeira exposição no sistema de parceria indígena, Tempo e Espaço no Amazonas: os Wajãpi, com curadoria da antropóloga Dominique Gallois. Como afirmam os autores, a mostra se apoiava nas quatro metas definidas pelo também antropólogo e então diretor do Museu do Índio, José Carlos Levinho, sendo elas: (1) o foco em culturas indígenas particulares, de modo a desfazer a visão preconceituosa do índio genérico; (2) a participação de antropólogos que trabalham com grupos indígenas específicos; (3) o estímulo à participação dos grupos indígenas cujas culturas seriam representadas, de forma a fomentar o intercâmbio entre diferentes culturas e também de oferecer possíveis resultados aos próprios indígenas; (4) a inserção da exposição no contexto de modernização da instituição, de maneira que ela tenha a mesma importância de mostras representativas de outras culturas.

De acordo com Guedes et al. (2017), o projeto de parcerias, chamado de "Museu do Índio de Cara Nova: instalação de uma exposição de longa duração e implantação de um sistema de proteção patrimonial", visava ao mesmo tempo atribuir um novo valor à autoridade indígena e uma nova significação ao Museu do Índio e tinha como objetivos a divulgação das culturas indígenas e a inclusão dos indígenas nos processos de musealização. Trata-se de uma reformulação imperativa frente ao fato de que a cultura e a história indígenas estão ou ausentes dos museus brasileiros ou historicamente representadas de maneira a inferiorizar esses povos, retratando-os como selvagens ou como um grupo único. 
A museóloga Marilia Xavier Cury (2012) lança algumas questões que refletem parte dos desafios dessa investigação [...]: "onde entram as culturas indígenas nos museus?"; "como ampliar o contato dos profissionais de museus com grupos indígenas e quais metodologias poderiam ser aplicadas para essa aproximação?"; e, finalmente, "o que os museus podem fazer pelas culturas e povos indígenas?". Tais questões de ordem política e também simbólica nos apontam para novas aplicabilidades do instrumento museu nas disputas identitárias, nas lutas por demarcações de terras, e na representação social no mundo contemporâneo. (GUEDES et al., 2017, p. 4).

Conforme destacam Guedes et al. (2017), devido à localização do MAR na área conhecida como Pequena África, a história da população negra traficada para o Brasil perpassa muitas exposições e ações do museu de maneira geral. No entanto, a temática indígena não é trabalhada com a mesma intensidade. Ao trazer a questão indígena, como ressaltam, o MAR estava sujeito a repetir a lógica de muitos museus ocidentais, onde predominam os discursos e as representações de arte ocidentais e onde a arte indígena é colocada no lugar do artesanato ou do artefato etnográfico. No entanto, os autores defendem, com base em Clifford (2003), a possibilidade de reverter uma prática museológica colonial através de uma museologia cooperativa. Assim, questionam:

Poderia o museu, com suas rotinas financeiras, jurídicas, burocráticas e disciplinares - provenientes de uma racionalidade ocidental - e com a relação que estabelecem, por exemplo, com o mercado de arte, operar de fato em colaboração com saberes e culturas outras? (GUEDES et al., 2017, p. 16).

A exposição Dja Guata Porã, como relata Baker (2018), foi inicialmente pensada pelo primeiro diretor cultural do MAR, Paulo Herkenhoff, e submetida no plano anual para a lei Rouanet com o nome A Guanabara antes dos cariocas $^{82}$. Um dos pontos relevantes para se notar é a atualização desse nome, que anteriormente sustentava a ideia do indígena como algo do passado - antes dos cariocas -, uma visão que a mostra, depois de pronta, contestava.

Segundo Baker (2018), a primeira descrição do projeto era bem genérica, basicamente estabelecendo a questão dos povos indígenas como tema. Foi feita

\footnotetext{
${ }^{82}$ No evento Conversa de Galeria - Pororoca, Herkenhoff anuncia uma exposição indígena para o próximo ano, Guanabara antes dos cariocas, em conjunção com uma coleta de acervo de arte indígena. Na palestra Arte: História, Crítica e Curadoria, Herhenhoff também já anunciava: "Vai ter um seminário ano que vem, onde só índio vai falar".

MUSEU DE ARTE DO RIO. Conversa de Galeria - Pororoca: A Amazônia no MAR. 27 out. 2014. (2h23m02s). Disponível em: https://youtu.be/4zXKzB1ynaU. Acesso em 06 jul. 2020. MUSEU DE ARTE DO RIO. Palestra com Paulo Herkenhoff - Arte: História, Crítica e Curadoria (PUC/SP). 08 dez. 2014. (1h29m02s). Disponível em: https://youtu.be/xls-a3sPTZ8. Acesso em: 20 mar. 2020.
} 
então uma reunião com o diretor do Museu do Índio, José Carlos Levinho, a fim de buscar a indicação de um especialista da questão indígena para atuar na equipe curatorial. Assim, surgiu o nome de José Ribamar Bessa Freire, professor da Universidade Federal do Estado do Rio de Janeiro (Unirio), que passou a integrar o projeto. Herkenhoff já havia também sugerido o nome de Pablo Lafuente, curador espanhol, que já tinha colaborado em alguns eventos na Escola do Olhar e que, desde que participou na curadoria da $31^{\mathrm{a}}$ Bienal de São Paulo, voltava seu interesse à questão indígena.

De início as pesquisas foram em busca de iconografia representativa dos indígenas brasileiros. Pensava em utilizar na exposição famosos quadros indigenistas como: Primeira Missa no Brasil, de Victor Meirelles; Iracema, de José Maria de Medeiros; e o Último Tamoio, de Rodolfo Amoedo. A exposição seguiria o caminho das demais exposições do MAR, uma adaptada revisão historiográfica de representações dos indígenas na arte brasileira até o momento atual, em conjunto com artefatos indígenas presentes na coleção do Museu assim como outros objetos de instituições parceiras e, provavelmente, algumas obras comissionadas por artistas contemporâneos que tratassem de questões relacionadas à cultura indígena. Um caminho que diversas exposições e curadorias seguem, tratar do outro sem, necessariamente, a troca efetiva com esse outro. (BAKER, 2018, p. 2604).

De acordo com Baker (2018), a entrada de Sandra Benites, que é Guarani, foi fundamental para a reelaboração do plano para a exposição. O desligamento de Herkenhoff da direção curatorial também foi um facilitador para que a ideia inicial fosse revista. O passo inicial foi pensado em forma de seminário e visava uma aproximação com os indígenas e com seu conceito de arte.

\begin{abstract}
Assim, foi realizado um programa dentro da Escola do Olhar onde convidávamos indígenas que trabalhavam em museus ou eram artistas e demais indivíduos que dialogavam com a interseção entre arte ocidental e arte indígena, indivíduos que problematizavam apropriações de museus ocidentais de artefatos indígenas e como as etnias estavam se colocando atualmente em relação a essas questões. (BAKER, 2018, p. 2605).
\end{abstract}

Segundo Vieira (2019), a equipe do MAR na época da elaboração de Dja Guata Porã era composta pelas curadoras Clarissa Diniz, Julia Baker, Angelica Padovani, Mariana Morais e Marina Martinez, pela curadora de arte e educação Janaina Melo e pela museóloga Andrea Santos. Além destas, foram convidados para a curadoria José Ribamar Bessa Freire, professor da Unirio e UERJ, o curador Pablo Lafuente e Sandra Benites, que, além de ser Guarani, era, na época, doutoranda em Antropologia Social pelo Museu Nacional/ UFRJ. A equipe de 
pesquisa foi composta por Ana Paula da Silva, Ignácio Gomez, Leandro Guedes e a própria Mariane Vieira.

Em meio às reuniões da equipe, conforme relata Baker (2018), surgiu o questionamento se os indígenas teriam o interesse de entrar no espaço museal e, caso sim, o que gostariam de expor. A equipe foi então buscar a resposta nas aldeias dentro do estado do Rio de Janeiro. As primeiras aldeias visitadas foram as da Costa Verde, Paraty Mirim e Sapukai. A primeira sugestão foi a venda de artesanato. A equipe depois refletiu sobre a produção de arte indígena para uma venda após a exposição, tendo em vista o fato de que é comum que artistas e galerias de arte emprestem suas obras para mostras em museus a fim de aumentar o seu valor comercial. No entanto, como argumenta a autora, a venda de obras de arte não faz parte das funções do museu, o lugar apropriado para isto é a galeria de arte. A autora aponta ainda duas outras questões na sugestão: o fato de o museu ser público, vinculado à Prefeitura, e a exposição do próprio indígena como um vendedor ao lado de sua obra ou artefato artesanal, podendo ser vista como uma fetichização do indivíduo. Assim, a ideia de venda foi abandonada. Para que outras sugestões fossem possibilitadas, os indígenas foram convidados a visitar o museu e conhecer o funcionamento de uma exposição.

Baker (2018) conta então que o segundo grupo ao qual a equipe se aproximou foi o de indígenas em contexto urbano, da Aldeia Maracanã e da Aldeia Vertical. Este grupo demonstrou um interesse categórico em estar no museu para mostrar a sua luta, ganhar visibilidade e reafirmar a sua existência.

O passo seguinte, segundo a autora, foi levar representantes de todas as aldeias que participariam da exposição para o museu, onde fizeram uma visitação às exposições que estavam em cartaz.

Após várias reuniões tanto no museu quanto nas aldeias e, a partir delas, foram organizados para a exposição quatro núcleos: Guarani, Puri, Índios em Contexto Urbano e Pataxó. Em seguida, as aldeias pensaram no que produziriam para a exposição e o planejamento seguiu o fluxo comum a qualquer mostra do museu (VIEIRA, 2019; BAKER, 2018).

Guedes et al. (2017) frisam que, desde o momento da pesquisa, a equipe percebeu que dois povos tinham histórias que se destacavam como representativas de processos que se passaram com grupos indígenas por todo o país: os Guarani, pela resistência, e os Puri, pela recente ressurgência. Os Guarani compõem o povo 
aldeado em maior número no estado do Rio de Janeiro. Existem sete aldeias da etnia no estado, situadas nos municípios de Paraty, Angra dos Reis e Maricá. Quanto aos Puri, os autores destacam os estudos do historiador Marcelo Lemos (2016) sobre os povos indígenas que, no século XIX, viviam na região sul do estado, os Coropó, os Coroado e os Puri. Esses povos enfrentaram um processo bárbaro de genocídio pelos barões do café da área do Vale do Paraíba. Os Puri foram considerados extintos, não apenas porque de fato muitos morreram, mas também devido à tática de sobrevivência utilizada pelos remanescentes de ocultamento da identidade. Atualmente, os Puri estão em processo de ressurgência étnica, regressando ao cenário social e exigindo reconhecimento e direitos.

Além dessa divisão por etnias, foram estabelecidas "estações" relativas aos temas comuns aos povos indígenas, que se repetiriam em todos os núcleos, sendo elas: educação, comércio, natureza, mulheres e arte. As curadorias das estações seriam de responsabilidade de cinco indígenas. Uma das estações, a Natureza, saía do espaço expositivo e transbordava na Praça Mauá, onde Niara do Sol, filha de índios Fulni-ô e Kariri, cultivou uma horta em um dos canteiros, com ervas medicinais e alimentos (VIEIRA, 2019; BAKER, 2018).

Já a Estação da Educação, como expõe Vieira (2019), era coordenada pela professora Anari Braz Bomfim, que atuou na produção de um vídeo sobre a importância da educação diferenciada. Havia também a Estação da Arte, coordenada pelo professor Edson Kayapó, onde foi ressaltada a relação entre a arte e a ancestralidade. Foi criada ainda, com a coordenação da escritora Eliane Potiguara, a Estação das Mulheres, que continha a narrativa da história de mulheres indígenas e sua vinda para o Rio de Janeiro.

Ao longo do processo, conforme relata Baker (2018), a equipe percebeu que o título da exposição, Guanabara antes dos Cariocas, não condizia mais com o que ela havia se tornado. Portanto, ele foi repensado, vindo a receber o nome Dja Guata Porã: Rio de Janeiro indígena. Como mencionado anteriormente, dja guata porã, em guarani, significa "caminhar bem e caminhar junto".

Durante o evento Conversa de Galeria (MAR, 2017, vídeo 14), Clarissa Diniz afirma que a equipe do museu realizou uma tarefa muito mais de mediação do que de curadoria. Diz ainda que o caminho que a exposição seguiria foi por muito tempo incerto e, somente após alguns meses, Dja Guata Porã começou a 
tomar alguma forma. Sandra Benites, em participação no evento, afirma que o processo foi, ao mesmo tempo, de diálogo e de conflito.

De acordo com Baker (2018), as decisões eram tomadas em conjunto e, em alguns casos, por meio de "votações", nas quais a vontade inicial da equipe curatorial do museu era frustrada. Relata a autora que alguns pontos foram de extrema incerteza. Um deles era a da categorização de alguns artefatos indígenas como obras. O outro era a recepção do público e de como ocorreria a quebra da expectativa de quem esperava um imagético estereotipado do povo indígena.

Dja Guata Porã foi um paradigma na forma de se fazer curadoria quando se propõe a inserir quem será retratado/pesquisado no processo de criação da exposição. Uma exposição colaborativa onde a criação das obras era sempre pensada em conjunto. Os curadores se tornaram articuladores do campo da arte. Negociavam não apenas com os participantes, mas com a instituição na qual a exposição estaria inserida e com o próprio campo da arte ao alargar o entendimento de uma exposição em um museu de artes sobre - e com - os indígenas cariocas. Apesar do risco e das incertezas que o resultado da exposição poderia trazer, ao realizar a experiência da curadoria participativa, abriu-se um precedente para a instituição, o de tentar incluir vozes diferentes, vozes dos retratados e não apenas daqueles legitimados como agentes do mundo das artes. (BAKER, 2018, p. 2610).

Ainda quanto à fase de planejamento da exposição, Guedes et al. (2017) apresentam um relato de como se desenvolveu o processo de pesquisa. Segundo os autores, a equipe de pesquisa foi dividida de acordo com os séculos.

O ponto de partida para se pensar a presença indígena no território fluminense em uma perspectiva histórica tomou como base as alianças estabelecidas entre índios, portugueses e franceses com a invasão francesa e a criação da França Antártica, discutindo a relação destas nos conflitos e relações com o colonizador português. Assim, a pesquisa se voltou aos aldeamentos indígenas do século XVI do que hoje conhecemos como território do Rio de Janeiro e ao processo de dizimação dos povos promovido pelos portugueses através do uso dos indígenas como força de trabalho escravo, das guerras justas e "resgates", entre outros instrumentos de violência física e simbólica. Aqui importou destacar a política de catequização forçada que, ao logo dos séculos, colaborou com o desaparecimento de línguas e saberes milenares, com o abandono de costumes e cosmogonias, e com mudanças na organização social das aldeias. (GUEDES et al., 2017, p. 9).

É pertinente notar como a equipe de pesquisa coloca ênfase no branco colonizador e na sua atuação de violência física e simbólica, trazendo o indígena como vítima, ao passo que, nas discussões presenciais com os grupos indígenas, o foco recaiu sobre práticas de resistência e insurgência. Em um dos encontros (MAR, 2017, vídeo 15), por exemplo, Tonico Benites, antropólogo Guarani Kaiowá, afirma que o que é realmente surpreendente não é a quantidade de 
indígenas que foram exterminados, mas sim o grande número de indígenas que ainda resistem, mesmo após mais de 500 anos de colonização.

Vieira (2019) explicita o que constava em cada parte da exposição e como se deu a participação dos indígenas na construção das obras e dos espaços.

Primeiramente, a rampa de acesso recebeu a instalação sonora dos fundadores da Rádio Yandê, Erick Marcio Mendes Muniz, conhecido como Anápuáka Muniz, da etnia Tupinambá e Pataxó Hã-Hã-Hãe, e Denilson Monteiro, da etnia Baniwa, mais conhecido como Denilson Baniwa. Ouviam-se depoimentos e cantos em diferentes línguas indígenas. Segundo Benites \& Lafuente (2018), existem atualmente mais de 250 línguas originalmente brasileiras, ou seja, indígenas, que ainda são faladas, mas que, assim como os povos que as falam, raramente são ouvidas. A instalação mostrava essa multiplicidade de línguas faladas no estado do Rio e contrastava com a instalação sonora na rampa de saída, em que podiam ser ouvidos os mesmos depoimentos e cantos em português. Considerando o contraste entre as duas instalações, uma antes e outra depois, é notável o quanto a lógica colonial reduziu a população do estado do Rio, marcada inicialmente por uma diversidade, a uma uniformidade, passando de uma realidade plural a uma homogeneizante.

Vieira (2019) descreve também a linha do tempo construída como parte da exposição, cujo primeiro esboço foi feito por Ana Paula da Silva e Bessa Freire. Essa linha foi montada a partir de registros historiográficos e obras de arte e mostrava um panorama da história dos povos indígenas para além do estado do Rio de Janeiro. A linha do tempo foi dividida em quatro tempos: tempo da autonomia, da invasão, da usurpação e tempo das retomadas. Ainda sobre a linha, a autora destaca:

[...] três linhas de argumentação foram estabelecidas: a história indígena de uma maneira mais ampla e cronológica, os eventos que aconteceram especificamente no estado do Rio de Janeiro e os mitos dialogando com a estrutura histórica mais fluida. Os mitos aparecem na linha do tempo como uma forma de apreensão do mundo e de seus fenômenos. (VIEIRA, 2019, p. 11).

Essa linha do tempo, conforme afirmam Benites \& Lafuente (2018), entrava imageticamente na mostra através da Cobra do Tempo, obra de Denilson Baniwa. Trata-se do desenho de uma serpente, que percorria a parede da exposição e que é uma referência a uma lenda indígena, mais especificamente dos povos do Alto 
Rio Negro. Segundo a lenda, a humanidade surgiu de uma cobra-canoa nascida da Baía de Guanabara, que levou os seres humanos até a Ilha de Marajó, no Pará, entrando pelo rio Amazonas e distribuindo os povos pelo Brasil.

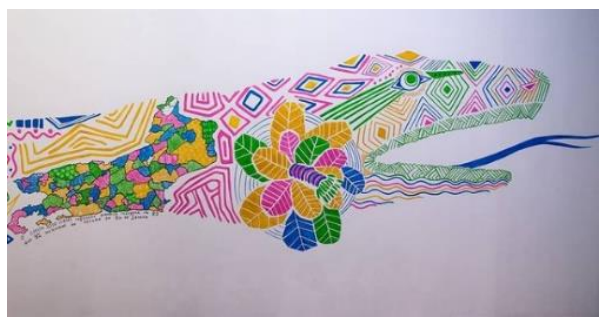

Figura 18: Detalhe de Cobra do Tempo - Denilson Baniwa.

Foto do Instagram do MAR.

Na primeira sala da exposição, conforme descreve Vieira (2019), havia o núcleo Pataxó. Esse povo, que originalmente ocupava a área entre o sul da Bahia e o norte de Minas Gerais, foi destituído de sua terra, o que fez com que parte dele, que procurou se distanciar dos conflitos, se deslocasse para Paraty, no estado do Rio de Janeiro. Esse grupo que veio para Paraty tenta hoje conseguir a demarcação de terras.

Os Pataxó produziram para a exposição um vídeo de caráter documental sobre seu deslocamento para o Rio de Janeiro, que recebeu o nome Pataxó Hã Hã Hãe. Além disso, expuseram objetos de uso cotidiano e que produzem para comercialização, e também um mapa da aldeia, pirografado em madeira.

Na sala seguinte, segundo Vieira (2019), estava o núcleo Puri. A presença dessa etnia é registrada desde o século XVI como ocupantes das regiões do Vale do Paraíba e da Zona da Mata Mineira. Foram destituídos de seu território devido ao aumento da fronteira agrícola e, como já mencionado, durante algum tempo, foram considerados extintos. Entretanto, criaram o Movimento de Ressurgência Puri.

Os Puri expuseram objetos utilitários e artísticos. Entre as obras desse núcleo, Vieira (2019) destaca uma pilastra que foi transformada em tronco e que trazia em suspenso uma espiral de tecido com frases em puri. Os itens contrapunham o argumento da extinção dos Puri e marcavam a sua presença que, no Rio de Janeiro, se deu especialmente em articulação com a Aldeia Maracanã.

O núcleo seguinte era o de indígenas em contexto urbano. As aldeias urbanas foram representadas pela Aldeia Vertical e a Aldeia Resiste (Aldeia Maracanã). A narrativa tinha início com a história da aldeia multiétnica conhecida 
como Aldeia Maracanã, que foi palco de muitas disputas nos anos em que ocorreram os grandes eventos na cidade do Rio, quando os indígenas foram obrigados a deixar o prédio do antigo Museu do Índio, ao lado do estádio do Maracanã. Passada essa fase, um dos líderes da aldeia, Zé Guajajara, junto a um grupo de indígenas, retomou o prédio e criou a Aldeia Resiste. A história foi contada no museu através do vídeo A saga da Aldeia Maracanã (2017) de Eduardo Pereira. Foram exibidas também fotografias da coleção pessoal de Afonso Aporinã, um dos indígenas da Aldeia. Além destas, houve a exibição de outras obras de registro ou artísticas.

O próximo núcleo correspondia ao dos Guarani, que, segundo Vieira (2019), se diferenciavam dos demais indígenas por serem os únicos com algumas aldeias demarcadas. A autora destaca a fala de uma das participantes, Ivanildes Pereira da Silva, que afirma que o grupo se entusiasmou com o convite para a exposição porque seria a primeira vez que poderiam mostrar sua cultura sem que um juruá $a^{83}$ interferisse. Os temas que ganharam maior foco nas discussões entre as aldeias Guarani foram a relação com o território, dentro dela, a caminhada, e a religiosidade. Foram exibidos vídeos produzidos por cineastas Guarani, além de obras de outros suportes.

Vieira (2019) destaca que a Escola do Olhar promoveu visitas mediadas à exposição, em sua maioria com escolas públicas. E os indígenas também ofereceram ações pedagógicas junto ao museu. Além disso, ocorreram outras atividades em torno da temática da exposição, como o Curso de História do Rio de Janeiro.

Grande parte dos eventos, como cursos, palestras, conversas de galeria, entre outros, está documentada em vídeo e disponível no canal do YouTube do MAR, todavia nem todos. Entretanto, quanto ao momento de planejamento da exposição, Guedes et al. (2017), realizam uma espécie de relato dos encontros, que também foram chamados de "Dja Guata Porã”. Segundo os autores, eles aconteceram em quatro ocasiões.

O primeiro ocorreu em novembro de 2016, com a mediação de Pablo Lafuente. Durante a manhã, falaram Sandra Benites, Bessa Freire, que integravam

\footnotetext{
${ }^{83}$ Os indígenas utilizam a palavra "juruá" para se referirem ao não indígena. É também recorrente o uso do vocábulo "branco" e da expressão "homem branco".
} 
a equipe curatorial, e Edson Kayapó, historiador, doutor em educação e professor do Instituto Federal da Bahia (IFBA). À tarde, o debate foi mais aberto com a plateia, composta por indígenas, em grande parte moradores da Aldeia Vertical, que abriga aqueles que foram expulsos da Aldeia Maracanã, incluindo o cacique Carlos Tukano, além de um grupo de Puri que vive em contexto urbano. Afirmam os autores que muitos temas foram abordados no primeiro encontro, como a questão da arte indígena no mundo ocidental, sendo discutido como ela é inserida e representada nos museus e como, nas instituições do mundo inteiro, os acervos indígenas catalogados são escassos. Ainda em relação à sua arte, outros assuntos mencionados foram a ligação entre a arte e a espiritualidade, a substituição de alguns materiais utilizados devido ao desmatamento, a necessidade de venda de sua arte, sob a forma de artesanato, que se torna para alguns grupos sua principal fonte de renda e a assimilação de novas tecnologias como forma de resistência, como o caso de indígenas que vêm entrando na área de audiovisual. Além disso, foram discutidas a expulsão de suas terras e a vida em contexto urbano.

O segundo encontro, conforme apresentam os autores, aconteceu ainda no mesmo mês. Ele contou com a participação do professor e pesquisador Josué Carvalho, indígena Kaingang, que tratou da preparação do museu para operar com as dimensões sagrada, de uso cotidiano e de produção comercial dos objetos indígenas. Para ele, o museu não deveria apenas representar a possibilidade de salvaguarda das memórias, mas também a de revivê-las.

Em dezembro de 2016, aconteceu o terceiro encontro, que teve dois momentos distintos. No primeiro, surgiram assuntos como a responsabilidade do museu em relação a exibir a realidade dos povos indígenas na atualidade, a capacidade de organização e mobilização indígena, a demarcação de terras, a vivência indígena em contexto urbano, incluindo os preconceitos e a supressão e diluição de suas identidades. A segunda parte do encontro foi conduzida quase integralmente em idioma guarani e voltou-se às questões trazidas pelos indígenas Guarani. Segundo os autores, tratou-se de uma experiência única para a parte da equipe formada por não indígenas, que "experienciou a incompreensão linguística e a breve perda do protagonismo político e simbólico na arena de debate" (GUEDES et al., 2017, p. 14). Os autores evidenciaram ainda que alguns indígenas, principalmente os Guarani, viam a exposição com desconfiança, 
temendo que a mostra perpetuasse uma historicidade ocidentalizada a respeito do indígena e que retratasse a identidade indígena de forma monolítica.

O quarto encontro ocorreu em fevereiro de 2017, sendo este voltado somente à questão da mulher indígena.

Para Guedes et al. (2017), Dja Guata Porã constituiu uma experiência muito maior do que o simples diálogo entre indígenas e não indígenas ou da representação do indígena no museu. Foi um processo que problematizou as estruturas de uma instituição fundamentada em uma experiência ocidental e colonial. Os debates que integraram a exposição, para os autores, se caracterizam como exercícios de descolonização, que, em certa medida, engajaram não somente a equipe que atuou diretamente com a mostra, mas todos os funcionários do museu - e é ainda possível acrescentar o público visitante.

Ao possibilitar o acesso a estas dimensões culturais e simbólicas colocando indígenas em evidência, o museu auxiliaria numa possível desestigmatização dos povos dentre seus próprios funcionários. Ainda não é comum para uma parcela considerável da população brasileira - o que se percebia mesmo dentro do museu - conceber um indígena como professor universitário, conforme o caso de Edson Kayapó, ou mesmo uma mulher indígena que desempenhasse a função de curadora de uma exposição, como Sandra. (GUEDES et al., 2017, p. 13).

Pablo Lafuente, ao ministrar a terceira aula do curso História da Arte Brasileira (MAR, 2018, vídeo 16), que compunha parte das atividades de Dja Guata Porã, destaca que realizar eventos para debater o tema da exposição em cartaz já é uma prática comum em alguns museus. Entretanto, segundo ele, estes eventos não afetam o conteúdo ou o processo de construção da mostra ou, se o fazem, é de maneira sutil. Esta seria, portanto, a diferença fundamental de Dja Guata Porã, a criação a partir desses encontros.

Guedes et al. (2017) ressaltam que levar a questão indígena para o museu, em um formato em que os próprios indígenas conduzissem a narrativa era essencial à época, diante da conjuntura em que a cidade do Rio de Janeiro e o país se encontravam. Na época, o Museu do Índio no Rio de Janeiro, um museu federal, estava fechado e o país vivia uma fase de fragilidade democrática que colocava os direitos dos indígenas em risco, com o avanço da proposta do Marco Temporal, a Comissão Parlamentar de Inquérito (CPI) da Fundação Nacional do Índio (FUNAI) e do Instituto Nacional de Colonização e Reforma Agrária 
(INCRA), a nomeação de um general do Exército à presidência da FUNAI e a tramitação da Proposta de Emenda Constitucional 215 (PEC 215).

Em um dos encontros (MAR, 2017, vídeo 17), Eloy Terena, advogado indígena, que atuava então na Articulação dos Povos Indígenas do Brasil (APIB), explicou o que significavam estas propostas e em que medida constituíam um ataque aos povos indígenas. O Marco Temporal é um projeto do Supremo Tribunal Federal (STF), pelo qual os povos indígenas somente poderiam pedir a demarcação das terras que já ocupavam na data em que foi promulgada a Constituição, em 1988. A medida desconsidera que, anteriormente a esta data, muitos grupos indígenas já tinham sido forçados a deixar suas terras. Já a CPI da FUNAI e do INCRA acusa de irregularidades lideranças indígenas, antropólogos, procuradores e pessoas ligadas ao Conselho Indigenista Missionário (CIMI), órgão da Igreja Católica que trabalha em apoio aos indígenas. Trata-se, conforme relata o advogado, de um instrumento para a perseguição de lideranças indígenas e apoiadores. E a PEC 215 visa delegar a demarcação de territórios indígenas e quilombolas exclusivamente ao Congresso Nacional, o que, na prática, significa impedir que mais áreas sejam demarcadas.

Bessa Freire, em participação na Conversa de Galeria (MAR, 2017, vídeo 14), também destaca a relevância da exposição naquele momento. Sinaliza que, recentemente, o então Ministro da Justiça, Osmar Serraglio, havia minimizado os ataques que os indígenas Gamela estavam sofrendo no Maranhão, se referindo a eles como "supostos índios". Nesse sentido, afirma que a exposição "vem reafirmar que o Rio de Janeiro continua índio e continua resistindo".

A antropóloga Els Lagrou, ao ministrar a segunda aula do curso História da Arte Brasileira (MAR, 2018, vídeo 18), frisa que a mostra coloca a cidade para refletir sobre sua relação com a realidade indígena. Ressalta como um conteúdo importante a abordagem do recente conflito na Aldeia Maracanã. Para ela, o recebimento dos grandes eventos na cidade, quando os olhares do mundo se voltavam ao Brasil, poderia ter sido uma ocasião perfeita para visibilizar a população indígena. Entretanto, o momento foi marcado por uma ação autoritária, violenta e desastrosa de tentativa de expulsão da população indígena que ocupava o antigo Museu do Índio. Uma das consequências consistiu no fechamento do atual Museu do Índio, em Botafogo, onde estava em exibição a mostra No Caminho da Miçanga: O mundo que se faz de contas, da qual Lagrou foi 
curadora. Assim, a mostra do MAR se constituía ainda como um espaço de reencontro entre a arte e o ativismo.

Ivair Reinaldim, professor da UFRJ, que ministrou a primeira aula do curso História da Arte Brasileira (MAR, 2018, vídeo 19), revelou seu contentamento ao ver a grande quantidade de escolas públicas visitando a exposição. Segundo ele, uma presença tão grande da escola pública não é algo muito comum para grande parte dos equipamentos culturais, entretanto, é de extrema importância se o que se pretende é causar qualquer espécie de transformação. E diz ainda que transformar é uma das funções da arte.

Reinaldim destaca que, na descrição de Dja Guata Porã, não existe a palavra "arte", mas seu papel no curso seria lidar com este tema. Para ele, algo que o museu precisa considerar é que há uma diferença grande entre o entendimento de arte em culturas indígenas e o que se concebe como arte na cultura ocidental. Os povos originários veem a arte como algo que engloba uma dimensão simultaneamente material e imaterial e que não está apartado da vida.

Os artistas indígenas enfrentam ainda, de acordo com Reinaldim, alguns preconceitos em relação à sua produção. Algumas pessoas, por exemplo, são relutantes em perceber que os indígenas não pararam no passado e também aprenderam coisas novas, apropriando-se de novos materiais e novas formas de fazer arte. Outros sustentam ainda uma visão purista, que não aceita que os indígenas incorporem elementos de outras culturas. Um exemplo que Reinaldim destaca é a polêmica causada por Denilson Baniwa, quando criou uma Mona Lisa índia, obra que recebeu o nome de La Gioconda Kunhã. O artista sofreu duras críticas por utilizar uma referência da cultura ocidental.

A respeito de uma categorização da arte indígena, Reinaldim afirma que, para alguns, como Darcy Ribeiro, existe uma Arte Índia, mas, para outros, existem artes indígenas. Na primeira perspectiva, não se negam as diferenças entre a produção artística de etnias indígenas distintas, mas percebe-se uma identificação de um grupo de produções como uma só categoria, a Arte Índia. Na segunda visão, é imprescindível diferenciar cada produção artística de acordo com o povo que a produz. Na concepção de Els Lagrou, citada por Reinaldim em sua aula, a arte contemporânea já expandiu o conceito de arte, logo, tornou-se incontestável a afirmação de práticas indígenas enquanto arte. Segundo ela, tratase de um tipo de produção muito semelhante à que existiu no ocidente antes do 
Renascimento, por ser uma estética de ordem relacional, que parte de uma forma diferente de perceber a autoria e a relação entre arte e vida, arte e artefato.

Lagrou (MAR, 2018, vídeo 18) sinaliza, no entanto, que é necessário compreender a dificuldade em traduzir conceitos não indígenas para a realidade indígena como uma diferença, não como uma falta. Afirma ainda que, embora os conceitos sempre levem consigo traços de sua origem, eles podem ser atualizados. Assim, arte e estética foram conceitualizadas pela sociedade ocidental como fenômenos que existem fora do âmbito da vida comum, da mesma maneira que o sagrado e o profano são compreendidos como manifestações de campos distintos. Contudo, esses conceitos não são universais.

Pablo Lafuente, na terceira aula do curso História da Arte Brasileira (MAR, 2018, vídeo 16), destaca que a situação da arte indígena em outros países já assumiu novos contornos, mas, no Brasil, ainda é forte a representação dos indígenas através de imagens feitas por brancos, seja na pintura ou na fotografia. O seu objetivo em Dja Guata Porã, enquanto curador, era remover do museu essas imagens e quebrar com o vício de contar a história dos outros. Nesse sentido, comenta que está se tornando frequente a discussão sobre o lugar de fala, mas este é um tópico mais complexo do que parece. Diz ele: "Não é uma questão de não poder falar, mas de como você fala, como você se engaja com essa posição de fala, com que pessoas você fala".

Tratar de interculturalidade, de parcerias e de práticas colaborativas não significa eliminar o conflito e a disputa. Pelo contrário, ambos se manifestam ainda mais. Alguns encontros de Dja Guata Porã evidenciam esses momentos de embate. No vídeo Construção em diálogo (MAR, 2017, vídeo 20), que exibe um encontro para o planejamento da Estação Mulheres, é possível observar alguns exemplos.

Estão presentes no encontro, além de um público espontâneo de cerca de 15 pessoas entre indígenas e não indígenas, Clarissa Diniz, Pablo Lafuente e Sandra Benites, da equipe curatorial, Eliane Potiguara, que era responsável pela Estação Mulheres, Aline Patchamama, parceira da exposição, que estava então elaborando uma publicação sobre ela, e Niara do Sol, à frente da Estação Natureza.

Depois de todos se apresentarem, Eliane Potiguara pergunta o que um carioca gostaria de ver em uma exposição sobre mulheres indígenas. Júlia, uma indígena entre os presentes como público espontâneo, e Sandra Benites 
discordam, afirmando que a pergunta certa seria o que as mulheres indígenas querem mostrar, não o que os brancos querem saber sobre elas. Eliane responde que a intenção é democratizar.

Depois de algumas sugestões de indígenas e não indígenas quanto ao que expor, um homem não indígena, que não diz seu nome, afirma que seria interessante mostrar um pouco da trajetória de mulheres indígenas individualmente. No entanto, Sandra Benites interrompe e afirma que a questão pode ser bem mais complexa do que parece, porque existiu e ainda existe uma violência muito grande contra as mulheres indígenas. Então, diz ela: "Eu carrego a força de falar o que minha avó não podia falar".

A fala de Sandra é cheia de idas e vindas e, por vezes, parece desconexa. Ela interrompe a discussão sobre o que expor, aparentemente, ainda querendo dizer que o importante não era ouvir os juruá, mas sim as mulheres indígenas. Nesse caso, ao que parece, ela quer dizer que contar a própria trajetória pode ser uma tarefa muito difícil, porque inclui a trajetória das mulheres que vieram antes dela e que não tiveram esse privilégio. Assim, uma trajetória individual pode parecer algo pequeno, mas talvez não caiba nos limites de uma exposição. A ponderação de Sandra Benites condiz com a cultura indígena de maneira geral, que não trabalha com tempos pré-estabelecidos, institucionalizados, e que é fundamentalmente relacional, não individualizada. Fica evidenciada, então, a dificuldade em realizar a transposição de uma forma de viver e de perceber o mundo para um molde tão diferente, da cultura indígena para a instituição branca.

Respondendo à Sandra, Eliane diz: "Nós vamos oferecer o conteúdo, os juruá vão oferecer a forma, a tecnologia”. E questiona: "Como materializar esses temas em uma exposição?”.

Eliane Potiguara afirma que compreendeu o objetivo da exposição como o de apresentar a cultura, a vivência e os conhecimentos indígenas para que as pessoas se sensibilizem e se humanizem. Pablo Lafuente, no entanto, diz que não existe um objetivo único e, na verdade, cada um se interessa pela exposição por um objetivo próprio, que pode ser simplesmente para buscar mais conhecimento, havendo uma variedade de objetivos institucionais e pessoais. Todavia, para ele, é importante frisar o que a exposição não poderia ser. A exposição não poderia ter como intenção abarcar toda a realidade da mulher indígena. Se referindo às histórias pessoais que cada uma contou no início do evento ao se apresentarem, 
afirma que nenhuma exposição poderia "dar conta dessas vidas", mas "pode capturar fragmentos, histórias, assuntos".

Em sua aula no curso História da Arte Brasileira (MAR, 2018, vídeo 16), Lafuente ressaltou a dinâmica da construção da exposição como o que considerou mais interessante, exatamente pelos embates e negociações que eram ensejados. Conta que, em uma das reuniões que aconteceram no MAR com as aldeias Guarani para decidir o conteúdo de seu núcleo, os Guarani decidiram se comunicar em sua língua e depois traduziram sua decisão para os curadores. Como demoraram para chegar a um consenso, a reunião durou sete horas. Assim, Lafuente destaca que a equipe do museu percebeu que seria necessário interferir para ajustar as reuniões ao ritmo institucional, estabelecendo um tempo limite e pontuando objetivos claros para cada encontro.

Lafuente afirma ainda que esses encontros o fizeram aprender algo que agora parece óbvio: "Existem muitos jeitos de ser indígena". Relata que percebeu que cada grupo tinha uma forma própria de se organizar e de dialogar, alguns com hierarquia e outros sem. Nessa perspectiva, destaca que o MAR possui um projeto mais orgânico em comparação com outras instituições, porque a curadoria, o educativo e outros setores exercem uma troca constante, mas há ainda uma hierarquia. Entretanto, ressalta que é uma instituição que se destaca: "Eu não sei que outro museu no Brasil teve uma reunião de sete horas em guarani!”. Ele acredita que o MAR é o único museu no país que aceitaria trabalhar da maneira proposta e afirma que não consegue imaginar esse processo em outras instituições.

Para Lafuente, um problema fundamental das instituições de arte hoje é o fato de que um grupo muito pequeno de pessoas detém todo o poder de decisão. Nesse sentido, destaca que, na Bienal, por exemplo, o conteúdo é decidido pela diretoria, composta por um grupo de pessoas da elite paulistana, e pelo curador, que pode atuar sozinho ou em equipe e que pode se envolver ou não com o educativo. A estrutura do MAR é mais complexa, porque envolve a diretoria da OS, a Prefeitura, a equipe de curadoria e o setor educativo, que ocupa um espaço interessante na instituição, com uma produção de conteúdo própria, não subordinada à curadoria. Portanto, em sua concepção, há, no MAR, um certo nível de democratização na proposição de conteúdo, mas, ainda assim, existem algumas pessoas no museu que não são consultadas sobre o conteúdo a ser exposto, nem se gostaram ou se estão confortáveis com o que está em exposição. Para o curador, 
esta é uma questão que supera o simples populismo, ela diz respeito a como manter relações com as pessoas e de como fazer com que elas tenham também uma relação de construção com o que se desenvolve dentro do museu.

Nessa perspectiva, Lafuente destaca a relação que o MAR mantém com os moradores do Morro da Providência, que, em sua visão, é muito bonita. Por exemplo, durante o processo de montagem da exposição, o MAR fez aniversário de quatro anos e, em comemoração, um grupo de mulheres da Providência levou um lanche para os funcionários do museu. $\mathrm{O}$ curador considera esse gesto muito simbólico de como pessoas que não trabalham no museu têm esse museu como seu. Em comparação, menciona a polêmica ocorrida no Museu de Arte Moderna de São Paulo (MAM-SP) em torno da performance de um homem nu. Em alguns atos em defesa, conforme conta Lafuente, foi registrada uma foto em que se vê um grupo segurando papéis com os dizeres "Somos todos MAM", sendo quase todas as pessoas brancas e, notavelmente, de classe média ou alta. $\mathrm{O}$ argumento para tal defesa girava quase sempre em torno de uma expressão que lhe causa incômodo, a "liberdade de expressão artística", uma liberdade não extensiva para todos. Em sua visão, é inconcebível que, em um país com tanta desigualdade, se defenda uma liberdade de privilégio. Para ele, a cultura deveria trabalhar desfazendo privilégios.

Em específico sobre Dja Guata Porã, Lafuente afirma que acompanhou as discussões no Facebook, rede na qual as comunidades indígenas são muito ativas, e que viu um número significativo de comentários feitos por indígenas sobre a exposição, "reclamando com orgulho o projeto, porque estavam envolvidos ou porque outras pessoas indígenas estavam envolvidas". Houve críticas também, mas ele sentiu que as comunidades indígenas, de maneira geral, defenderiam a instituição por fazer a exposição. Para ele, isso evidencia que esse tipo de projeto possibilita transformar a relação entre a instituição e quem está fora dela, "esse fora já fica menos fora e não tem essa parede grande de vidro, de condomínio, que separa quem decide e quem não decide".

Denilson Baniwa, artista que participou da mostra, no evento Museus e Emergências Contemporâneas (MAR, 2017, vídeo 21), que fez parte do projeto geral da exposição, também elogia o MAR pelo trabalho. Ressalta que muitas pessoas vão em exposições sobre indígenas para apreciar o indígena à distância, sem se envolver, mas Dja Guata Porã trouxe uma outra proposta. Afirma ainda 
que tudo poderia ter sido feito pela própria equipe do museu, mas houve uma preocupação em pedir orientação e permissão para os povos indígenas. É uma abordagem que nunca havia visto em outro lugar. Segundo ele, nem todos ficaram satisfeitos, mas seria mesmo impossível contentar todo mundo.

$\mathrm{O}$ artista menciona também como as estruturas hegemônicas se valem de brechas das culturas minoritárias para perpetuarem ainda mais o seu projeto de uma maneira quase silenciosa. Se referindo ao slogan da campanha Agro: a Indústria-Riqueza do Brasil, promovida pela Rede Globo, diz ele que, a cada 15 minutos, é repetido dentro das casas brasileiras que o "agro é pop", até que as pessoas comecem a acreditar nisso e passem a ver quem está do lado oposto da indústria do agronegócio como um inimigo. Ainda sobre essa atuação hegemônica, menciona a apropriação que algumas marcas fazem dos grafismos e outras referências indígenas, em um uso puramente comercial de elementos significativos para determinadas culturas.

O professor Edson Kayapó, em participação no evento Museus $e$ Emergências Contemporâneas (MAR, 2017, vídeo 17), sinaliza que, em alguns casos, o projeto hegemônico opera por uma simples troca de nomes. O que antes se chamavam "capitanias" e "donatários", hoje denominam-se "agronegócio" e "empresários", mas a estrutura latifundiária é a mesma. A PEC 215 é também, segundo ele, apenas um novo nome para a "guerra justa". Outros recursos linguístico-discursivos são ainda utilizados para fazer com que os indígenas sejam vistos como inimigos. Nesse sentido, afirma que chamam de "invasão" a retomada de terras.

Joênia Wapichana, primeira mulher indígena a se formar em Direito no Brasil e, atualmente, deputada federal, em participação no mesmo evento (MAR, 2017, vídeo 22), sinaliza que os povos indígenas também têm encontrado estratégias para defender seus direitos. A principal delas é ocupar novos espaços institucionais, como na política ou em alguns sistemas que trabalham diretamente com questões indígenas, como a FUNAI. Uma estratégia interna em muitas aldeias é investir nos jovens, para que façam faculdade e consigam se expressar melhor dentro destes espaços. Além disso, destaca que é importante estabelecer alianças entre diferentes etnias e educar o não indígena para que ele se torne um aliado. Nessa perspectiva, ela afirma que é essencial aproveitar oportunidades que se abrem nas instituições, como o caso da exposição no MAR. 
Para Edson Kayapó (MAR, 2017, vídeo 17), o contato com os povos indígenas, como aquele possibilitado pela mostra, pode ser valioso para os não indígenas, porque são povos que viveram uma experiência histórica com a qual todos podem aprender. São pessoas, segundo ele, que resistiram a todo o tipo de opressão e se impuseram contra o projeto ocidental, científico, cartesiano, que já se mostrou insustentável. Em sua visão, "as pessoas tinham que repensar o desenvolvimento como um envolvimento" e perceber os saberes e práticas indígenas como uma forma outra de conviver com os seres visíveis e invisíveis e com o planeta em geral, uma forma essencialmente relacional.

\section{Lista de vídeos e eventos}

[evento 1] MUSEU DE ARTE DO RIO. \#MARé. Rio de Janeiro: Museu de Arte do Rio (MAR), 12 fev. de 2020.

[vídeo 8] MUSEU DE ARTE DO RIO. Palestra com Gleyce Heitor - Arte: História, Crítica e Curadoria (PUC/SP). 12 dez. 2014. (1h27m14s). Disponível em: https://youtu.be/dE-bcEiXedM. Acesso em: 22 mar. 2020.

[vídeo 9] MUSEU DE ARTE DO RIO. Conversa de Galeria Especial com Vizinhos Convidados. 24 mar. 2016. (44m23s). Disponível em: https://youtu.be/JtafdT5MJN0. Acesso em: 13 jul. 2020.

[vídeo 10] MUSEU DE ARTE DO RIO. Ofícios e Saberes da Região com Eliana Rosa. 06 mai. 2018. (16m33s). Disponível em: https://youtu.be/1 AeqPXMcHDA. Acesso em 13 jul. 2020.

[vídeo 11] MUSEU DE ARTE DO RIO. MAR na Rua - EP 5 "Cosmovisões Negras”, com Mãe Celina de Xangô. 19 dez. 2019. (3m29s). Disponível em: https://youtu.be/wTdw7N_U9JI. Acesso em: 03 ago. 2020.

[vídeo 12] MUSEU DE ARTE DO RIO. Conversa de Galeria com Vizinho Convidado. 12 nov. 2018. (36m42s). Disponível em: https://youtu.be/vquNjs3uwik. Acesso em 13 jul. 2020.

[vídeo 13] MUSEU DE ARTE DO RIO. Café com Vizinhos do MAR - Dezembro. 12 jan. 2015. (44m21s). Disponível em: https://youtu.be/Fun5AFNMPgs. Acesso em 13 jul. 2020.

[vídeo 14] MUSEU DE ARTE DO RIO. Conversa de Galeria | Dja Guata Porã: Rio de Janeiro indígena | Parte 1. 29 jun. 2017. (52m30s). Disponível em: https://youtu.be/fuFrz4kx4Go. Acesso em 20 jul. 2020.

[vídeo 15] MUSEU DE ARTE DO RIO. MAR na Academia :: Museus e Emergências Contemporâneas | Dja Guata Porã Dia 03 Parte 01. 28 set. 2017. (1h15m03s). Disponível em: https://youtu.be/G4j2egQJCGM. Acesso em: 23 jul. 2020.

[vídeo 16] MUSEU DE ARTE DO RIO. Dja Guata Porã :: Curso de História da Arte Brasileira - Aula 3. 29 jan. 2018. (1h21m51s). Disponível em: https://youtu.be/sV5bnL7qhts. Acesso em 27 jul. 2020.

[vídeo 17] MUSEU DE ARTE DO RIO. MAR na Academia :: Museus e Emergências Contemporâneas | Dja Guata Porã Dia 03 Parte 02. 28 set. 2017. (1h05m01s). Disponível em: https://youtu.be/AyemZid3hIQ. Acesso em: 23 jul. 2020. 
[vídeo 18] MUSEU DE ARTE DO RIO. Dja Guata Porã :: Curso de História da Arte Brasileira - Aula 2. 29 jan. 2018. (2h03m37s). Disponível em: https://youtu.be/4x_e8Y-c3hM. Acesso em 26 jul. 2020.

[vídeo 19] MUSEU DE ARTE DO RIO. Dja Guata Porã :: Curso de História da Arte Brasileira - Aula 1. 17 jan. 2018. (1h51m15s). Disponível em: https://youtu.be/BqV-5F1dVtY. Acesso em: 26 jul. 2020.

[vídeo 20] MUSEU DE ARTE DO RIO. Construção em diálogo - Dja Guata Porã. 7 mar. 2017. (3h29m33s). Disponível em: https://youtu.be/8ljDnheYaN0. Acesso em: 23 jun. 2020.

[vídeo 21] MUSEU DE ARTE DO RIO. MAR na Academia :: Museus e Emergências Contemporâneas | Dja Guata Porã Dia 01 Parte 01. 27 set. 2017. (1h34m09s). Disponível em: https://youtu.be/izVtOAp7SKw. Acesso em: 21 jul. 2020.

[vídeo 22] MUSEU DE ARTE DO RIO. MAR na Academia :: Museus e Emergências Contemporâneas | Dja Guata Porã Dia 03 Parte 03. 28 set. 2017. (1h20m33s). Disponível em: https://youtu.be/3YLBFVmA1Wc. Acesso em: 23 jul. 2020.

\section{3}

\section{Será que o MAR vai virar sertão? - O MAR em crise e o MAR em tempos de pandemia - Casa Carioca}

Como já discutido no subcapítulo 4.1, desde 2017, os equipamentos culturais do Rio de Janeiro que funcionam através de contratos de OS vinham experienciando dificuldades financeiras, devido à diminuição de repasse da Prefeitura. Em 2019, a crise orçamentária chegou ao seu limite. Os equipamentos mais afetados foram aqueles simbolicamente ligados à gestão anterior da Prefeitura, como o MAR e o Museu do Amanhã. Chegou a ser noticiado que os dois equipamentos poderiam fechar ao final de 2019. Como discutido no item 4.1.2, o MAR já vinha encontrando a solução para algumas questões de ordem financeira em novas parcerias e o Museu do Amanhã se ligou ainda mais ao capital privado. Ambos chegaram a ter uma redução significativa da equipe, mas, ao final daquele ano, a Prefeitura colocou as contas do contrato de gestão em dia e as instituições conseguiram seguir operando até o início de 2020. Entretanto, frente à pandemia do novo coronavírus que entrou no Brasil em 2020, todos os equipamentos culturais foram forçados a fechar desde março.

Como mencionado no capítulo 3, o MAR se manteve fechado durante quase todo o ano de 2020. Como uma maneira de compensar o não funcionamento físico da instituição, o museu buscou formas de operar online.

O fechamento do MAR aconteceu em 16 de março de 2020. A exposição Casa Carioca, cuja abertura estava agendada ainda para a primeira metade do ano, foi "aberta" virtualmente, através de uma transmissão ao vivo, realizada no 
canal do YouTube da instituição, pelos curadores, Marcelo Campos e Joice Berth. Aconteceu ainda a publicação no canal de vídeos de artistas, que comentam seu processo criativo e detalhes das obras que fariam parte da mostra. E houve, nas redes, a campanha \#CasaCariocaMAR, com publicações de vários tipos abordando a exposição e sua temática. O museu começou a publicar em suas redes imagens de obras de arte e dados levantados na pesquisa da exposição e a realizar algumas transmissões ao vivo sobre a mostra. A temática de Casa Carioca se volta à casa e às formas de habitar no Rio de Janeiro e no Brasil.

Durante esse período, o MAR se manteve significativamente mais ativo em suas redes. Além de publicações referentes à exposição, o museu relembrava, por meio de fotos em seu Instagram e Facebook, alguns momentos que marcaram os seus sete anos de história. Em julho, algumas atividades - antes presenciais foram retomadas em formato virtual como parte do Programa de educação museal online, que incluía oficinas, formações com professores, debates sobre a coleção, visitas mediadas e o Café com Vizinhos.

No YouTube, aconteceu o lançamento da série Percursos Mediados, que reproduzia, em formato de pequenos vídeos, momentos de uma visita mediada. Cada série, que corresponde a uma exposição, é formada por cinco episódios de cerca de três minutos. Até o momento de fechamento da coleta havia somente a série da mostra $O$ Rio dos Navegantes. Com a exceção dos dois últimos, todos os vídeos da série contam com tradução em Libras e audiodescrição para cegos. O penúltimo vídeo da série é de caráter experimental, buscando usar um tipo de linguagem menos tradicional na apresentação de uma obra ou de parte da mostra. No caso de O Rio dos Navegantes, o vídeo (MAR, 2020, vídeo 23) é montado em formato de videoclipe, utilizando como linguagem o passinho ${ }^{84}$ e apresentando, atrelada a outros momentos da mostra, a obra Ramos 13 de Julio Bittencourt, uma fotografia de um casal se beijando dentro do Piscinão de Ramos ${ }^{85}$. Nesta série, foi criado o jogo Contra Maré (MAR, 2020, vídeo 24), um vídeo interativo, no qual o "visitante" pode escolher o caminho que deseja seguir na exposição, clicando em

\footnotetext{
${ }^{84} \mathrm{O}$ passinho é um tipo de dança da cultura funk carioca, considerada um patrimônio cultural do Rio de Janeiro. A dança consiste basicamente em uma movimentação acelerada dos pés acompanhando a batida do funk.

${ }^{85}$ Piscinão de Ramos é o nome mais popular do Parque das Vizinhanças de Ramos Carlos de Oliveira Dicró, uma praia artificial com uma piscina pública de água salgada, situada no bairro de Ramos, subúrbio do Rio de Janeiro.
} 
uma das opções oferecidas. Cada opção é um link, que leva o "visitante" a outro vídeo, onde ele é apresentado à outra obra ou sala da exposição, com uma narração que oferece mais informações ou até mesmo uma leitura de um texto literário que se relaciona com a mostra, e onde ele pode escolher ainda outro caminho. É um jogo que proporciona autonomia para que o "visitante" desenhe sua própria rota de visita na mostra e que pode demandar bastante de seu tempo, caso queira conhecer todos os percursos possíveis.

Quanto a Casa Carioca, na transmissão ao vivo de abertura da exposição (MAR, 2020, vídeo 25), Marcelo Campos, o curador da mostra junto com Joice Berth, explica que a ideia surgiu a partir do fato estatístico de que $85 \%$ das casas brasileiras são autoconstruídas. Afirma ele que a mostra busca refletir sobre essa autoconstrução, seus protagonistas, a mulher enquanto um pilar da casa, a sociabilidade desse espaço e a ameaça de remoção.

Alguns elementos podem ser evidenciados a partir dos vídeos que compõem a mostra, publicados no YouTube. O primeiro deles é o fato de reverberar mais uma vez no museu a temática da moradia, já abordada em outras exposições, inclusive em $O$ Abrigo e o Terreno. Outro elemento a ser destacado, do campo da ironia, está no fato de que, durante o ano de 2020, devido à pandemia, as pessoas tiveram que ficar em casa e a própria exposição foi, a princípio, apreciada de casa. Isso faz com que Casa Carioca consiga agir na visibilização de questões como a falta de moradia ou situações de vulnerabilidade que algumas pessoas vivenciam dentro de suas próprias casas. Um último elemento é referente a uma comparação entre o grupo de artistas que participaram desta exposição, que podem ser vistos apresentando suas obras nos vídeos da playlist da mostra ${ }^{86}$, com os grupos que participaram das mostras Linguagens do Corpo Carioca $^{87}$ e Pororoca, que podem ser vistos nos vídeos do evento Conversa de Galeria (MAR, 2016, vídeo 26; 2014, vídeo 27). É possível perceber que Casa Carioca traz um corpo artístico

\footnotetext{
${ }^{86}$ Participaram de Casa Carioca os artistas: Alan Fontes, Ana Clara Tito, Ana Hortides, Bruno Portella, Diambe, Érica Magalhães, Gilson Plano, Maria Fernanda Lucena, Mariana Par, Maxim Malhado, max wíllà morais, Millena Lízia, Mulambö, Rafael BQueeer, Raquel Nava, Yhuri Cruz, Yuri Firmeza e outros, que não entraram na análise realizada por seus vídeos terem sido publicados após o fechamento da coleta. Todos os vídeos analisados estão listados nas referências, ao final desta dissertação.

${ }^{87}$ Linguagens do Corpo Carioca [a vertigem do Rio] (06/2016 - 10/2016), curadoria de Paulo Herkenhoff e Milton Guran.
} 
menos branco, menos hétero, menos masculino e mais plural, o que indica que o museu vem aprofundando ainda mais a reflexão sobre representatividade.

Quanto à reabertura do MAR para visitação, como mencionado no capítulo introdutório, ela se deu em 22 de setembro, mas com agendamento prévio, a fim de manter um controle no número de visitantes para, assim, evitar aglomerações e a possível disseminação da covid-19. Até o final de 2020, o museu ainda não havia retomado o funcionamento nos moldes anteriores à pandemia.

\section{Lista de vídeos}

[vídeo 23] MUSEU DE ARTE DO RIO. Percursos Mediados - O Rio dos Navegantes | EP 4 O amor mora em Ramos. 27 jul. 2020. (2m41s). Disponível em: https://youtu.be/9bIS-d-WREk. Acesso em: 04 ago. 2020.

[vídeo 24] MUSEU DE ARTE DO RIO. Percursos Mediados - O Rio dos Navegantes | EP 5 Contra-maré. 03 ago. 2020. (1m14s). Disponível em: https://youtu.be/xmSsTbw08tA. Acesso em: 04 ago. 2020.

[vídeo 25] MUSEU DE ARTE DO RIO. Casa Carioca - Live com os curadores Marcelo Campos e Joice Berth. 22 mai. 2020. (58m53s). Disponível em: https://youtu.be/Yw-aho_rFTc. Acesso em: 15 ago. 2020.

[vídeo 26] MUSEU DE ARTE DO RIO. Conversa de Galeria Linguagens do corpo carioca [a vertigem do Rio]. 15 jun. 2016. (45m30s). Disponível em: https://youtu.be/OJ57tJrZHeQ. Acesso em: 06 jul. 2020.

[vídeo 27] MUSEU DE ARTE DO RIO. Conversa de Galeria - Pororoca: A Amazônia no MAR. 27 out. 2014. (2h23m02s). Disponível em: https://youtu.be/4zXKzB1ynaU. Acesso em 06 jul. 2020. 


\section{5}

\section{A crença na delicadeza: Notas conclusivas}

A partir do panorama traçado das práticas estético-político-pedagógicas do Museu de Arte do Rio (MAR), é possível depreender que este museu nada contra a maré porque encontra brechas em um projeto hegemônico, busca enfoques outros, protagonistas outros, recebe todo o tipo de público, convida para o debate, para o embate e para a decisão do que expor, de como expor, de como construir conhecimento através desse instrumento chamado museu, um instrumento colonial que, aqui, se reinventa em um espaço de encontro e de aprendizagens, desaprendizagens e reaprendizagens. Trata-se de um encontro com vizinhos, com bebês, com crianças, com escolas, com a Pequena África, com saberes e sujeitos historicamente invisibilizados, com as suas próprias contradições, com o conhecimento e com a arte.

Concebe-se o projeto do MAR como um todo como a prática de uma pedagogia decolonial, no sentido amplo e não instrumentalista proposto por Walsh (2013). Ao trazer questões identitárias, ao criar regimes de representação que rompem com o quadro de referências tradicional dos museus, branco e europeu, ao suscitar a subversão de lógicas epistêmicas coloniais/ modernas/ eurocêntricas, ao afirmar a arte enquanto espaço epistemológico, o MAR indica alternativas ao projeto modernidade/ colonialidade, à história oficial da cidade do Rio de Janeiro e às formas tradicionais de construção de conhecimento.

Buscando dar uma resposta às questões inicialmente propostas, é possível afirmar que talvez o MAR, enquanto fruto de uma operação urbana gentrificadora e dentro de um modelo de gestão associado à privatização, não possa ser exatamente caracterizado como um museu decolonial. Não obstante, sim, ele possui algumas práticas que podem ser identificadas como parte de um projeto ético-político e epistêmico de decolonização. Há de se compreender, no entanto, que toda instituição tem as suas nuances, afinal são feitas por pessoas e são elas que lhe conferem sentido. Existem ainda limites dentro da atuação de um museu. Em relação à segunda questão colocada, as práticas estético-político-pedagógicas do MAR que se destacam são: a construção coletiva, a promoção do empoderamento local, a visibilização de conflitos, o fortalecimento de identidades, o reconhecimento de saberes outros e de modos outros de construir conhecimento. Elas podem ser consideradas transgressoras de uma lógica colonial 
e instauradoras de uma práxis outra na medida em que constituem "exercícios radicais de des-pensar, des-disciplinar e re-educar" (MALDONADO-TORRES, em entrevista para DREXLER-DREIS, 2014), instaurando um "giro decolonial".

O MAR demonstrou buscar a elaboração de ações que visem a democratização de suas práticas em sentido amplo, pensando na acessibilidade, na compreensão e até mesmo na participação de diferentes tipos de público, desde a curadoria das exposições até as práticas estritamente pedagógicas desenvolvidas pela Escola do Olhar, como cursos, debates, visitas educativas, entre outras.

Verificou-se que a Escola do Olhar apresenta em suas práticas uma orientação influenciada pela pedagogia libertadora freireana. Além disso, o MAR vivencia o contexto de tensão entre arte e mercado, associada aos mecanismos de privatização da cultura e à responsabilização social da iniciativa privada, como citado por Dalla Zen (2011). Entretanto, o caráter híbrido do museu parece possibilitar que ele se mantenha aberto para críticas de ambos os lados, da iniciativa privada e dos órgãos públicos. Os participantes dos debates e demais eventos se sentiram livres para fazer críticas negativas à própria instituição e aos seus patrocinadores, assim como também foram constantes os comentários em reprovação ao governo federal, estadual e municipal. Isso demonstra que o MAR encontra um campo de atuação em uma área fronteiriça (MIGNOLO, 2003 apud BALLESTRIN, 2013), buscando caminhos dentro da própria modernidade para exercer uma prática decolonial, assumindo "posturas, posicionamentos, horizontes e projetos de resistir, transgredir, intervir, insurgir, criar e incidir" (WALSH, 2013, p. 25, tradução nossa). Como indica Walsh (2013), a decolonialidade exige movimentos não-lineares.

Em $O$ Abrigo e o Terreno $^{88}$, evidenciou-se que alguns atores dentro do museu conseguem encontrar espaços nas brechas da colonialidade (WALSH, 2016), como elemento presente na própria instituição museu de maneira geral e no MAR em específico, enquanto parte de um projeto de gestão urbana diretamente ligada à globalização e, portanto, ao projeto moderno/ colonial. Há de se considerar ainda que a forma de gestão por organização social (OS) coloca o MAR em uma posição de ambiguidade, como um museu com um discurso curatorial, museográfico e educativo com grande potencial decolonial, mas

${ }^{88}$ O Abrigo e o Terreno (03/2013 - 07/2013), curadoria de Paulo Herkenhoff e Clarissa Diniz. 
institucionalmente colonizado (COCOTLE, 2019). No entanto, como indica Walsh (2016), as brechas se encontram dentro da própria colonialidade. Assim, alguns agentes de dentro do museu indicaram a visibilização de espaços de insurgência, mesmo diante de um projeto de gentrificação e privatização.

Em Dja Guata Pora $\tilde{a}^{89}$, foi possível visualizar a interculturalidade crítica, enquanto ferramenta pedagógica (WALSH, 2009), atuando em um projeto que questiona e desafia o modelo de sociedade atual e engendra um modo outro de fazer museu, que é fundamentalmente um fazer "com". A mostra, em seu aspecto processual, composta por eventos e debates que aproximavam agentes indígenas e não indígenas, proporcionou um encontro entre diferentes culturas e o intercâmbio de saberes. Além disso, visibilizou a causa indígena e seus protagonistas. A mostra constituiu ainda uma maneira de desalienação quanto ao indígena em contexto urbano e quanto à arte indígena.

Já Casa Carioca $^{90}$ demonstrou a atualidade de um museu que se pensa e se reinventa. Os caminhos encontrados para que a mostra acontecesse, ainda em tempos de isolamento social, confirmam a posição do MAR como um museu que se esforça para se manter aberto e atuante apesar das dificuldades encontradas.

Outras questões que atravessaram esta dissertação foram a relação que o museu cultiva com a população local e as maneiras que encontra de incluir diferentes públicos. Neste sentido, evidenciou-se que, de maneira geral, a população local tem uma relação de afeto com a instituição. E o museu possui práticas para a recepção de crianças e bebês que destoam da maioria dos equipamentos culturais da cidade, onde esta audiência geralmente não é adequadamente acolhida.

Uma das questões ainda a ser explorada em trabalhos futuros seria relativa aos motivos que levaram a experiência de Dja Guata Porã a não ter ainda se repetido em outras exposições. Mesmo que algumas obras da mostra tenham sido incorporadas ao acervo, a temática indígena ainda não ressoou no museu, como aconteceu com o tema da moradia, que é continuamente retomado em diferentes exposições. Além disso, não foram encontrados textos ou vídeos que demonstrassem que outro projeto com o mesmo nível de colaboração ocorreu na

${ }^{89}$ Dja Guata Porã: Rio de Janeiro indígena (05/2017 - 03/2018), curadoria de Sandra Benites, José Ribamar Bessa Freire, Pablo Lafuente e Clarissa Diniz.

${ }^{90}$ Casa Carioca (09/2020 - 09/2021), curadoria de Marcelo Campos e Joice Berth. 
instituição, mesmo que trabalhando com outro tema. Essa não reincidência leva ao questionamento se há uma interferência dos patrocinadores, que, no caso de Dja Guata Porã, receberam muitas críticas negativas dos participantes, em especial o Grupo Globo e a Fundação Roberto Marinho (FRM). Essa possível interferência desmancharia a imagem de liberdade e de abertura que o MAR constrói para si mesmo.

Outro ponto que pode ser aprofundado no futuro se refere às muitas parcerias do MAR e aos projetos que se associam oficial ou extraoficialmente à instituição. Uma possibilidade seria a de abordar como se desenvolve a relação do museu com as universidades, ou ainda com as escolas. $\mathrm{O}$ material analisado indicou que existem muitas ações que ultrapassam até mesmo os limites físicos do museu. Além disso, acompanhando a atividade do MAR nas redes, foi possível identificar alguns projetos que não tinham uma ligação oficial com o museu, mas que realizavam ações que se associavam a ele de alguma forma, como um grupo que realizava passeios pela Pequena África e tinha o MAR como ponto de encontro.

Por fim, há de se considerar como questão para desenvolvimento futuro a reabertura e a retomada das atividades do MAR após a pandemia, tendo ainda em vista que, em janeiro de 2021, foi confirmada a mudança na gestão da instituição, que agora passa a ter como responsável a Organização de Estados Iberoamericanos para a Educação, a Ciência e a Cultura (OEI), um organismo internacional. Ainda quanto à pandemia, é importante que haja um mapeamento de como essas instituições foram afetadas por este tempo longo de fechamento e como vão se reinventar, porque não há como passar por essa experiência e voltar a funcionar da mesma maneira.

Em relação à pandemia, ela afetou também o próprio processo de escrita desta dissertação. Por vezes, eu me via tentando me manter positiva e pensando no tempo que eu ganhava em não ter que sair de casa - e nem poder sair de casa. Outras vezes, eu questionava o propósito de tudo isso. Tantas coisas acontecendo, pessoas adoecendo e morrendo, outras perdendo o emprego e passando dificuldades. E, enquanto isso, eu estudava um museu! Muitas vezes parecia que me dedicava a algo sem o menor sentido.

Ao mesmo tempo, esse período de isolamento social me fez perceber a importância da arte e como ela me ajudava a manter o mínimo de sanidade mental 
diante da loucura que foi 2020. A arte operava não apenas na dimensão do entretenimento, de oferecer alguma atividade para me ocupar, mas também e principalmente no que tange ao diálogo para além da ordem do inteligível, um diálogo sensível. O sentido que eu percebi em estudar o MAR veio de perceber o próprio sentido da arte e da vida, um sentido que não é dado pela utilidade, mas pelos detalhes e pela delicadeza.

Em um dos vídeos da série Percursos Mediados ${ }^{91}$, Georges Gonçalvez, educador do MAR, fala sobre a obra de Claudia Jaguaribe, a fotografia Menina na Laje da série Entre Morros. A obra se encontrava dentro do núcleo "A natureza da Baía de Guanabara", na mostra $O$ Rio dos Navegantes $^{92}$. Como sinaliza o educador, ela contrasta com as obras que a antecedem no percurso da exposição, pinturas acadêmicas do final do século XIX da paisagem carioca. A fotografia tem uma perspectiva aérea, verticalizada, onde, em primeiro plano, está uma menina entrando em uma caixa d'água e, ao fundo, um cenário de favela que parece imenso, como se a laje onde a menina se encontra estivesse bem no alto do morro, com toda a favela se estendendo abaixo dela. A artista cria uma ilusão de unidade através do uso de diversos planos. A fotografia corta o imaginário das paisagens bucólicas de um Rio de Janeiro idealizado das pinturas que a antecedem. No canto superior esquerdo da fotografia, como destaca o educador, é possível ver o Morro Dois Irmãos, "a natureza exuberante distante de toda a turbulência da favela, como se não houvesse questões problemáticas a discutir”.

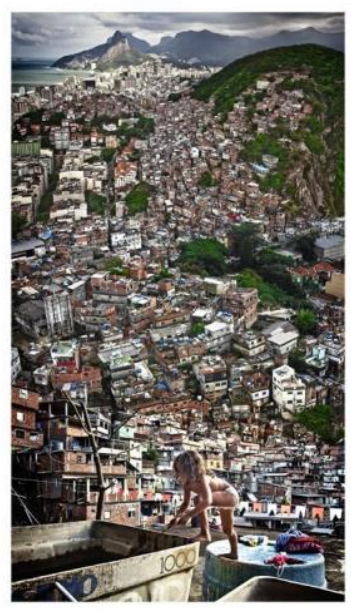

Figura 19: Menina na Laje - Claudia Jaguaribe

\footnotetext{
${ }^{91}$ MUSEU DE ARTE DO RIO. Percursos Mediados - O Rio dos Navegantes | EP 3 - Relações entre Claudia Jaguaribe e Rosana Paulino. 20 jul. 2020. (8m15s). Disponível em: https://youtu.be/V6UQYMBpAuc. Acesso em: 04 ago. 2020.

${ }_{92}$ O Rio dos Navegantes (05/2019 - 05/2020), curadoria de Evandro Salles, Fernanda Terra, Marcelo Campos, Pollyana Quintela e consultoria de Francisco Carlos Teixeira.
} 
A fotografia de Jaguaribe está entre as obras do acervo do MAR que mais gosto: A menina que despreocupadamente entra para seu banho na caixa d'água, enquanto a favela, com toda a sua carga imagética de violência, se estende imensa por baixo dela. Para mim, a obra convoca a pensar sobre as pessoas inocentes que são afetadas pelo conflito urbano, sobre como a vida é frágil e delicada.

É dentro dessa dimensão, da fragilidade e da delicadeza, que a arte opera. Neste sentido, é preciso concordar com o artista Armando Queiroz, que ao participar do evento Conversa de Galeria ${ }^{93}$, afirma: "A gente só pode violentar a violência senão com delicadeza. [...] Eu acredito na delicadeza".

${ }^{93}$ MUSEU DE ARTE DO RIO. Conversa de Galeria - Pororoca: A Amazônia no MAR. 27 out. 2014. (2h23m02s). Disponível em: https://youtu.be/4zXKzB1ynaU. Acesso em 06 jul. 2020. 


\section{Referências Bibliográficas}

ALMEIDA, Karina Figueiredo de; RIBEIRO, Rosina Trevisan Martins. Museu de Arte do Rio - MAR: Uma Abordagem do Valor Patrimonial. 3er Congresso Iberoamericano y XI Jornada Tecnicas de Restauracion y Conservacion del Patrimonio. Tópico 1 - № 18, 2013.

AMARAL, João Paulo Pereira do. Da colonialidade do patrimônio ao patrimônio decolonial. 2015. 166 f. Dissertação (Mestrado Profissional em Preservação do Patrimônio Cultural) - Instituto do Patrimônio Histórico e Artístico Nacional, Rio de Janeiro, 2015.

ANJOS, Moacir dos. Arte índia. Revista Zoom. jun. 2016. Disponível em: https//revistazoom.com.br/colunistas/arte-india. Acesso em: 20 jul. 2020.

ANJOS, Moacir dos (Curadoria). Arte, Democracia e Utopia: quem não luta tá morto $=$ Art Democracy Utopia: to fight or to fall (catálogo). Rio de Janeiro: Instituto Odeon, 2018.

ANGIOLILLO, Francesca. Em crise, Museu de Arte do Rio dá aviso prévio a todos os funcionários. Folha de São Paulo, São Paulo, 11 nov. 2019. Disponível em: https://www1.folha.uol.com.br/ilustrada/2019/11/em-crisefinanceira-museu-de-arte-do-rio-da-aviso-previo-a-todos-osfuncionarios.shtml. Acesso em: 03 dez. 2019.

ARAÚJO, Helena Maria Marques. Museu da Maré: entre educação, memórias e identidades. 2012. 238 f. Tese (Doutorado em Educação) Programa de Pós-Graduação em Educação, Pontifícia Universidade Católica do Rio de Janeiro, Rio de Janeiro, 2012.

ARIAS, Luciana. et al. Estudios decoloniales: Un panorama general. Kula. Antropólogos del Atlántico Sur. ISSN 1852 -3218, n. 6, abr. 2012.

BAKER, Julia. Curadoria participativa: O caso da exposição Dja Guata Porã no Museu de Arte do Rio (MAR). Anais do $27^{\circ}$ Encontro da Associação Nacional dos Pesquisadores em Artes Plásticas, pp. 2600-2611. São Paulo: Universidade Estadual Paulista (UNESP), Instituto de Artes, 2018.

BALLESTRIN, Luciana. América Latina e o giro decolonial. Revista Brasileira de Ciência Política, № 11, PP. 89 - 117, mai./ago. 2013.

BARBOSA, Andréa da Silva; SALDANHA, Gustavo Silva. O livro de artista, o colecionador e a coleção no museu: um intinerário intersubjetivo da coleção de livros de artista de Paulo Herkenhoff no Museu de Arte do Rio. InCID: Revista de Ciência da Informação e Documentação. Ribeirão Preto, v. 8, n. 2, p. 176-191, set/ 2017 - fev. 2018.

BARDIN, Laurence. Análise de Conteúdo. Lisboa: Edições 70, 2009. 
BARRAGÁN, Almudena. Cinco 'fake news' que beneficiaram a candidatura de Bolsonaro. El País, 19 out. 2018. Disponível em: https://brasil.elpais.com/brasil/2018/10/18/actualidad/1539847547_146583 .html. Acesso em: 03 jan. 2021.

BENITES, Sandra; LAFUENTE, Pablo. A Way of Working Together. On Dja Guata Porã: Rio de Janeiro indígena. South: As a State of Mind, Athens, v. 10, p. 74-79, $2018 . \quad$ Disponível em: http://southasastateofmind.com/article/a-way-of-working-together-on-djaguata-pora-rio-de-janeiro-indigena/. Acesso em: 15 jan. 2020.

BOING, Maria Clara Baldez. A educação praticada no/com o MAR: o que nos dizem gestos e narrativas dos educadores do museu? 2016. 106f. Dissertação (Mestrado em Educação) - Programa de PósGraduação em Educação, Universidade do Estado do Rio de Janeiro (UERJ), Rio de Janeiro, 2016.

BORGES, Fabiane; LIMA, Élida. Sobre a exposição Zona de Poesia Árida - Conversa de véspera. Catahistorias, blog de Fabiane M. Borges. 2015. Disponível em: https://catahistorias.files.wordpress.com/2015/01/ sobre-zona-de-poesia-c3a1rida1.pdf. Acesso em: 15 abr. 2020.

BRASIL. Lei 10.639/2003, de 9 de janeiro de 2003. Altera a Lei no 9. 394, de 20 de dezembro de 1996. Diário Oficial da União, Poder Executivo, Brasília.

BRITO, Joaquim Pais de. O museu, entre o que guarda e o que mostra. In: SEMEDO, Alice; LOPES, João Teixeira. Museus, Discursos e Representações. Porto: Edições Afrontamento, 2005.

BURKE, Peter. A Revolução Francesa da historiografia: a Escola dos Annales 1929-1989. Trad. Nilo Odália. São Paulo: Editora Universidade Estadual Paulista, 1991.

CALAZANS, Vevé; GERÔNIMO. Agradecer e Abraçar. Intérprete: Maria Bethânia. In: MARIA BETHÂNIA. A força que nunca seca. Rio de Janeiro: BMG, 1999.

CAMARGOS, Bruna et al. Seminário Internacional Desafio dos Museus no Século XXI. Rio de Janeiro: Instituto Odeon, 2018.

CANDAU, Vera Maria. "Ideias-força" no pensamento de Boaventura Sousa Santos e a educação intercultural. In: CANDAU, Vera Maria (org.) Interculturalizar, Descolonizar, Democratizar: uma educação "outra"? Rio de Janeiro: 7 Letras, 2016.

CANDAU, Vera Maria. Educación Intercultural Crítica: Construyendo Caminos. In: WALSH, Catherine (Ed.). Pedagogías Decoloniales: Prácticas insurgentes de resistir, (re)existir y (re)vivir (Tomo I). Quito Equador, Ed. Abya-Yala, 2013. 
CARNEIRO, Amanda; MESQUITA, André. Entre o visível e o não-dito: uma entrevista sobre histórias e curadoria com Lilia Moritz Schwarcz. Arte e Descolonização. MASP e Afterall, 2019. Disponível em: https://masp.org.br/arte-e-descolonizacao. Acesso em: 16 jan. 2020.

CAVALCANTI, Hannah da Cunha Tenório. Espaços museais e memórias sociais na zona portuária do Rio: $O$ Instituto dos Pretos Novos (IPN). 2016, 123f. Dissertação (Mestrado em Memória Social). Programa de Pós-Graduação em Memória Social. Universidade Federal do Estado do Rio de Janeiro (Unirio), Rio de Janeiro, 2016.

CARVALHO, Cristina. Quando a escola vai ao museu. Campinas: Papirus, 2016.

CARVALHO, Cristina; CAMPOLINA, Gabriela; MARTINS, Valéria. Bebês no MAR: Samba de roda para os pequenos no museu. V SEMINÁRIO LUSO-BRASILEIRO DE EDUCAÇÃO INFANTIL / II CONGRESSO LUSO-AFRO-BRASILEIRO DE INFÂNCIAS E EDUCAÇÃO. São Paulo, 2020. Disponível em: https://www.doity.com.br/anais/clabie2019/trabalho/ 128269. Acesso em: 15 out. 2020.

CHAVES, Thaís. Lei Rouanet: da ascensão à queda provocada pelas fake news. Carta Capital, 23 mai. 2019. Disponível em: https://www.cartacapital.com.br/cultura/lei-rouanet-da-ascensao-a-quedaprovocada-pelas-fake-news/. Acesso em: 03 jan. 2021.

COCOTLE, Brenda Caro. Nós prometemos descolonizar o museu: uma revisão crítica da política museal contemporânea. Arte e Descolonização. MASP e Afterall, 2019. Disponível em: https://masp.org.br/arte-e-descolonizacao. Acesso em: 14 nov. 2019.

DACOSTA, Alexandre Franco. O Rio do Samba - Resistência e Reinvenção. Concinnitas, ano 19, volume 01, número 32, PP. 382-387, ago. 2018.

DALLA ZEN, Laura Habckost. O dispositivo pedagógico da arte. 2011. 108f. Dissertação (Mestrado em Educação). Programa de Pós-Graduação em Educação. Universidade Federal do Rio Grande do Sul (UFRGS), Porto Alegre, 2011.

D’ANGELO, Ana Cristina. Um MAR de arte e educação. Página 22: Informação para o novo século. Seção Página Cultural, n. 73. São Paulo: FGV, abr. 2013.

DE LIRA BOTTURA, Ana Clara. O Paradigma Da Cidade Global E As Olimpíadas Do Rio De Janeiro. Oculum Ensaios, vol. 11, n. 1, jan-jun, pp. 119-135 Campinas: Pontifícia Universidade Católica de Campinas, 2014.

DÍAZ, José Alberto Romaña; MUNHOZ, Angélica Vier. Práticas Educativas no Museu de Arte do Rio. Revista Educação, Artes e Inclusão. ISSN 1984-3178, v. 15 n. 2, abr. - jun. 2019. 
DINIZ, Clarissa (org.). Pernambuco Experimental (catálogo). Rio de Janeiro: Instituto Odeon, 2014.

DINIZ, Clarissa; CARDOSO, Rafael (org.). Do Valongo à Favela: Imaginário e periferia (catálogo). Rio de Janeiro: Instituto Odeon, 2015.

DREXLER-DREIS, Joe. Interview: Nelson Maldonado-Torres. 9th Newsletter of Centre for Liberation Theologies. Leuven, Belgium, October, 2014. Disponível em: https://theo.kuleuven.be/en/research/ centres/centr_lib/newsletter-clt-9-maldonado-torres-interview.pdf. Acesso em: 12 nov. 2019.

DUSSEL, Enrique. Europa, modernidade e eurocentrismo. In: LANDER, E. (comp.). La colonialidad del saber: eurocentrismo y ciencias sociales. Perspectivas latinoamericanas. Buenos Aires: CLACSO, 2000.

EQUIPE MAR. Mulheres na coleção MAR (catálogo). Rio de Janeiro: Instituto Odeon, 2019.

ESCOBAR, Arturo. Mundos y conocimientos de outro modo: el programa de investigación de modernidad/colonialidad latinoamericano. Tabula Rasa. Bogotá - Colombia, № 1, pp. 51-86, jan/dez 2003.

ESTELITA, Mariana. O contexto epistêmico do museu e da história da arte a partir de uma abordagem decolonial. Concinnitas. v. 20, no 35 , setembro, 2019.

FERREIRA, Ricardo Franklin; CALVOSO, Genilda Garcia; GONZALES, Carlos Batista Lopes. Caminhos da Pesquisa e a Contemporaneidade. Psicologia: Reflexão e Crítica. 15 (2), pp. 243-250, 2002.

FREIRE, Quintino Gomes. Museu de Arte do Rio pode fechar as portas. Diário do Rio, Rio de Janeiro, 12 nov. 2019. Disponível em: https://diariodorio.com/museu-de-arte-do-rio-pode-fechar-as-portas/.

Acesso em: 03 dez. 2019.

GALEANO, Eduardo. 0 livro dos abraços. Tradução de Eric Nepomuceno. Porto Alegre: L\&PM, 9.ed, 2002.

GHANEM, Elie. Educação formal e não-formal: Do sistema escolar ao sistema educacional. In: TRILLA, Jaume et al. (Org.). Educação formal e não-formal: pontos e contrapontos. São Paulo: Summers, 2008.

GIL, Carmen Zeli de Vargas; MEINERZ, Carla Beatriz. Educação, patrimônio cultural e relações étnico-raciais: possibilidades para a decolonização dos saberes. Horizontes, v. 35, n. 1, p. 19-34, jan./abr. 2017.

GIL, Antonio Carlos. Como elaborar projetos de pesquisa. $4^{\underline{a}}$ Ed. São Paulo: Atlas, 2002. 
GOLDMAN, Marcio. Cavalo dos Deuses: Roger Bastide e as transformações das religiões de matriz africana no Brasil. Revista de Antropologia. v. 54 n. 1. São Paulo, USP, 2011.

GUEDES, Leandro; SOUZA, Luciana; BRULON, Bruno. Dja Guata Porã: Construções em diálogo. In: Seminário Brasileiro de Museologia, III, 2017, Belém. Anais III Sebramus. Belém: Universidade Federal do Pará, 2017.

HONORATO, Raquel. Museu de Arte do Rio pode fechar as portas por falta de repasse da prefeitura a funcionários. G1, Rio de Janeiro, 11 nov. 2019. Disponível em: https://g1.globo.com/rj/rio-de-janeiro/noticia/2019/ 11/12/museu-de-arte-do-rio-pode-fechar-as-portas-por-falta-de-repasseda-prefeitura-a-funcionarios.ghtml Acesso em: 03 dez. 2019.

HOOKS, Bell. Olhares Negros: raça e representação. São Paulo: Elefante, 2019.

JANDIR, Jr. Dentro - Programa Sala de Encontro: Museu de Arte do Rio, Rio de Janeiro - Abertura: 25 de março de 2017. Arte \& Ensaios, revista do PPGAV/ EBA/ UFRJ, n. 33, jul. 2017.

JORNAL NACIONAL. Artistas protestam contra extinção do Ministério da Cultura. G1, 17 mai. 2016. Disponível em: http://g1.globo.com/jornalnacional/noticia/2016/05/artistas-protestam-contra-extincao-do-ministerioda-cultura.html. Acesso em: 03 jan. 2021.

LEITE, Caroline Alciones de Oliveira; OLIVEIRA, Luiz Sérgio de. Arte, educação e poder: discursos ocultos nas narrativas de museus brasileiros de arte. Ouvirouver. Uberlândia, v. 11, n. 2, p. 462-476, jul./dez. 2015.

LEMINSKI, Paulo. Caprichos \& Relaxos. $3^{\text {a }}$ ed. São Paulo: Brasiliense, 1985.

LISPECTOR, Clarice. Para não esquecer. Rio de Janeiro: Rocco, 1999.

LOPES, João Teixeira. Notas conclusivas: Os museus como terceiras culturas. In: SEMEDO, Alice; LOPES, João Teixeira (coord.). Museus, Discursos e Representações. Porto: Edições Afrontamento, 2005.

LOPES, Thamiris Bastos. Outras Formas de Conhecer o Mundo: Educação Infantil em Museus de Arte, Ciência e História. 2019. 221 f. Tese (Doutorado em Educação) - Programa de Pós-Graduação em Educação. Pontifícia Universidade Católica do Rio de Janeiro. Rio de Janeiro, 2019.

MACHADO, Célia. Museus e vizinhança - o desafio de partilhar território. Ensaios e Práticas em Museologia. Porto, Departamento de Ciências e Técnicas do Património da FLUP, 2012, vol. 2, pp. 70-91.

MALDONADO-TORRES, Nelson. Sobre la colonialidad del ser: contribuciones al desarrollo de un concepto. In: CASTRO-GÓMEZ, Santiago; GROSFOGUEL, Ramón (Orgs.). El giro decolonial. 
Reflexiones para una diversidad epistémica más allá del capitalismo global. Bogotá: Universidad Javeriana-Instituto Pensar, Universidad Central-IESCO, Siglo del Hombre Editores, 2007. p. 127-167.

MARTINS, Sérgio Bruno. Port of call. Artforum, vol. 52, n. 9, May 2014.

MARTINS, Sérgio Bruno. O MAR de cima a baixo. Blog do IMS. 7 abr.,2013. Disponível em: blogdoims.com.br/o-mar-de-cima-a-baixo-porsergio-bruno-martins. Acesso em: 30 out. 2019.

MARTINS, Sérgio Bruno. Tunga: Museu de Arte do Rio. Artforum, vol. 57, n. 2, p. 239-50, out. 2018.

MENDES, Mario. Um ato de beleza: a mostra da Coleção Boghici, no novo Museu de Arte do Rio, apresenta um importante painel de dois séculos de cor, caos e paixão. Veja, vol. 46, issue 2322, p. 130, mai. 2013.

MICHAELIS. Moderno Dicionário da Língua Portuguesa. Disponível em: http://michaelis.uol.com.br. Acesso em: 01 ago. 2020.

MIGNOLO, Walter. Colonialidade: o lado mais escuro da modernidade. Revista Brasileira de Ciências Sociais. vol. 32, n. 94. São Paulo: 2017.

MIGNOLO, Walter. A colonialidade está longe de ter sido superada, logo, a decolonialidade deve prosseguir. Arte e Descolonização. MASP e Afterall, 2019. Disponível em: https://masp.org.br/arte-e-descolonizacao. Acesso em: 14 nov. 2019.

MIGNOLO, Walter. Aesthesis decolonial. Calle 14. v. 4 n. 4, p. $10-25$. jan. - jun. 2010.

MIRANDA, Claudia; ARAÚJO, Helena Maria Marques. Memórias contrahegemônicas e educação para as relações étnico-raciais: práticas decoloniais em contextos periféricos. Perspectiva: Revista do Centro de Ciências da Educação, vol 7 no 2, p. 378 - 397. Florianópolis, abr./ jun., 2019.

MOMBAÇA, Jota. A plantação cognitiva. Arte e Descolonização. MASP e Afterall, 2020. Disponível em: https://masp.org.br/arte-e-descolonizacao. Acesso em: 05 set. 2020.

MOTTA, Gustavo de Moura Valença. Discursos de Contrainformação: Coletivos de artistas e curadores-autores no Brasil (2000-2015). 2018. Tese (Doutorado em Artes) - Programa de Pós-Graduação em Artes Visuais. Universidade de São Paulo. São Paulo, 2018.

MOURA, Roberto. Tia Ciata e a Pequena África no Rio de Janeiro. $2^{a}$ Ed. Rio de Janeiro: Secretaria Municipal de Cultura, Dep. Geral de Doc. e Inf. Cultural, Divisão de Editoração, 1995. 
MUNHOZ, Angélica Vier; COSTA, Cristiano Bedin da; GUEDES, Betina Silva. Notas sobre uma residência pedagógica no Museu de Arte do Rio. Revista GEARTE, Porto Alegre, v. 3 n. 3, p. 367-381, set/ dez. 2016.

MUÑIZ-REED, Ivan. Pensamentos sobre práticas curatoriais no giro decolonial. Arte e Descolonização. MASP e Afterall, 2019. Disponível em: https://masp.org.br/arte-e-descolonizacao. Acesso em: 14 nov. 2019.

MUSEU DE ARTE DO RIO. Museu de Arte do Rio. Homepage da instituição. Disponível em: museudeartedorio.org.br.

NOBRE, Ana Luiza. A city at play. Rio de Janeiro on the eve of the 2016 Olympic and Paralympic Games. Architectural Design, 3, vol. 86, 2016.

OLEIRO, Manuel Bairrão. Apresentação. In: SEMEDO, Alice; LOPES, João Teixeira. Museus, Discursos e Representações. Porto: Edições Afrontamento, 2005.

OLIVEIRA, Cêurio de. Dicionário Cartográfico. IBGE. 4a Ed. Rio de Janeiro, RJ, 1993. Disponível em: https://www.ibge.gov.br/geociencias/ metodos-e-outros-documentos-de-referencia/vocabulario-e-

glossarios/16496-dicionario-cartografico.html. Acesso em: 15 ago. 2020.

OLIVEIRA, Luiz Fernandes de; CANDAU, Vera Maria Ferrão. Pedagogia decolonial e educação anti-racista e intercultural no Brasil. Educação em Revista. v. 26, Belo Horizonte, 2010.

OLIVEIRA, Maria Marly de. Como fazer pesquisa qualitativa. $3^{\underline{a}}$ ed. Petrópolis: Vozes: 2008.

PADRÓ, Carla. Educación en museos: representaciones y discursos. In: SEMEDO, Alice; LOPES, João Teixeira. Museus, Discursos e Representações. Porto: Edições Afrontamento, 2005.

PADUAN, Roberta; SILVA, José Benedito da. Investigação sobre fake news reaviva fantasma que assombra Bolsonaro. Veja, 29 mai. 2020. Disponível em: https://veja.abril.com.br/brasil/investigacao-sobre-fakenews-reaviva-fantasma-que-assombra-bolsonaro. Acesso em: 03 jan. 2021.

PEREIRA, Marcele Regina Nogueira. Museologia Decolonial: Os Pontos de Memória e a insurgência do fazer museal. 2018. Tese (Doutorado em Museologia). Universidade Lusófona de Humanidades e Tecnologias. Lisboa, 2018.

PUCU, Izabela; CAMARGOS, Bruna. A Pequena África e o MAR de Tia Lúcia: Homenagem a Maria de Lúcia dos Santos (catálogo). Rio de Janeiro: Instituto Odeon, 2019.

PUCU, Izabela; CAMARGOS, Bruna (Ed.). O Olhar dos Vizinhos no Jornal da Zona. 2ª Ed. Rio de Janeiro: Instituto Odeon, nov. 2019. 
PUCU, Izabela; NICHOLS, Natália (org.). Jornada de educação e relações étnico-raciais do MAR. Rio de Janeiro: Instituto Odeon, 2018.

PUCU, Izabela; NICHOLS, Natália; ZACA, Rafael (org.). Dispositivos Artístico-Pedagógicos. Rio de Janeiro: Instituto Odeon, 2019.

QUIJANO, Aníbal. Colonialidad del poder, eurocentrismo y América Latina. In: LANDER, Edgardo (comp.). La colonialidad del saber: eurocentrismo y ciencias sociales. Perspectivas latinoamericanas. Buenos Aires: CLACSO, 2000.

RAMOS, Luiza Gomes. Mergulho no MAR: Um estudo-reportagem sobre - Museu de Arte do Rio - A relevância sociocultural de um museu temático da cidade do Rio de Janeiro. 2014. Monografia (Graduação em Comunicação Social - Jornalismo). Universidade Federal do Rio de Janeiro. Rio de Janeiro, 2014.

REBOUÇAS, Natália Pinto. Navegar é preciso: decolonização de saberes no MAR. In: CANDAU, Vera Maria (Org.). Pedagogias decoloniais e interculturalidade: insurgências. Rio de Janeiro: APOENA, 2020.

RIBEIRO, Débora. O conhecimento moderno-ocidental à luz do pensamento decolonial latino-americano: aprender, desaprender $e$ reaprender a partir dos movimentos sociais. Currículo sem Fronteiras. v. 18, n. 3, PP. 1057- 1076, set./dez. 2018.

ROSÁRIO, Miguel do. Com ataques à cultura e à educação, Temer mostra que seu objetivo é calar as vozes dissidentes. O Cafézinho, 19 mai. 2016. Disponível em: https://www.ocafezinho.com/2016/05/19/comataques-a-cultura-e-a-educacao-temer-mostra-que-seu-objetivo-e-calaras-vozes-dissidentes. Acesso em: 03 jan. 2021.

SALLES, Evandro et al (org.). O Rio do Samba: resistência e reinvenção (catálogo). Rio de Janeiro: Instituto Odeon, 2018.

SALLES, Evandro et al (org.). O Rio dos navegantes (catálogo). Rio de Janeiro: Instituto Odeon, 2019.

SANTOS, Maria Célia Teixeira Moura. Encontros museológicos: reflexões sobre a museologia, a educação e o museu. Rio de Janeiro: MinC/ IPHAN/ DEMU, 2008.

SÁ-SILVA, Jackson Ronie; ALMEIDA, Cristóvão Domingos de; GUINDANI, Joel Felipe. Pesquisa documental: pistas teóricas e metodológicas. Revista Brasileira de História \& Ciências Sociais. Ano I, Número I, jul. 2009.

SCHWARCZ, Lilia Moritz. 0 espetáculo das raças: cientistas, instituições e questão racial no Brasil - 1870 - 1930. São Paulo: Companhia das Letras, 1993. 
SEMEDO, Alice. Introdução. In: SEMEDO, Alice; LOPES, João Teixeira. Museus, Discursos e Representações. Porto: Edições Afrontamento, 2005.

SILVA, Joana Angélica Flores. Mulheres negras e a construção de gênero na construção das narrativas nos museus de Salvador. Revista Mosaico. v. 9, n. 2, p. 178-188, jul./ dez. 2016.

SILVA, Vanessa de Freitas. \#museumselfie: sociabilidades mediadas por imagens conectadas no Instagram. 160f. Dissertação (Mestrado em Comunicação Social) - Universidade do Estado do Rio de Janeiro (UERJ), Faculdade de Comunicação Social, 2018.

SOUZA, Angela Gomes de. Museu de Arte do Rio - MAR: Reflexões sobre arte contemporânea, cidade e museus. Revista do Colóquio de Arte e Pesquisa do PPGA-UFES, ano 3, v.3, n.5, dezembro de 2013.

TRILLA, Jaume. A educação não-formal. In: TRILLA, Jaume et al. (Org.). Educação formal e não-formal: pontos e contrapontos. São Paulo: Summus, 2008.

TURINO, Célio. Lei Rouanet e a cultura em demolição. Outras Palavras, 24 abr. 2019. Disponível em: https://outraspalavras.net/crise-brasileira/leirouanet-e-a-cultura-em-demolicao. Acesso em: 03 jan. 2021.

VALENTE, Maria Esther Alvarez. Educação e museus: a dimensão educativa dos museus. In: GRANATO, Marcus; SANTOS, Claudia Penha dos; LOUREIRO, Maria Lucia de N. M. (Org.). Museu e Museologia: interfaces e perspectivas. Rio de Janeiro: Museu de astronomia e Ciências Afins, 2009.

VARINE, Hugues de. Um instrumento do desenvolvimento: o museu. In: VARINE, Hugues de. As raízes do futuro: o patrimônio a serviço do desenvolvimento local. Porto Alegre: Ed. Medianiz, 2012.

VIEIRA, Mariane Aparecida do Nascimento. Dja Guata Porã: O rio indígena que desaguou no MAR. In: Horizontes Antropológicos. v. 25 p. $227-256,31$ jan. 2019.

WALSH, Catherine. Lo pedagógico y lo decolonial: Entretejiendo caminos. In: WALSH, Catherine (Ed.). Pedagogías Decoloniales: Prácticas insurgentes de resistir, (re)existir y (re)vivir (Tomo I). Quito - Equador, Ed. Abya-Yala, 2013.

WALSH, Catherine. Notas pedagógicas a partir das brechas decoloniais. In: CANDAU, Vera Maria (org.). Interculturalizar, Descolonizar, Democratizar: uma educação "outra"? Rio de Janeiro: 7 Letras, 2016.

WALSH, Catherine. Interculturalidad y (de)colonialidad: perspectivas críticas y políticas. In: ANAIS DO XII CONGRESSO DA ARIC, Florianópolis, 2009. 
WORLD HEALTH ORGANIZATION. Coronavirus disease (COVID-19) pandemic. Disponível em: https://www.who.int/emergencies/diseases/ novel-coronavirus-2019. Acesso em: 01 ago. 2020.

\section{1}

\section{Eventos presenciais}

GONÇALVES, Guilherme Leite. Um porto no capitalismo global: desvelando as acumulações entrelaçadas no Rio de Janeiro. IV Seminário Arte, Cultura e Poder (Seminário). Rio de Janeiro: Universidade do Estado do Rio de Janeiro (UERJ), 2019.

MUSEU DE ARTE DO RIO. \#MARé. Rio de Janeiro: Museu de Arte do Rio (MAR), 12 de fevereiro de 2020.

\section{2}

\section{Obras de Arte}

BANIWA, Denilson. Cobra do Tempo. Mural. $75 \mathrm{~m}$. Rio de Janeiro: Museu de Arte do Rio, 2017.

BANIWA, Denilson. La Gioconda Kunhã. Infogravura. Dimensões variáveis. 2017.

BANIWA, Denilson; MUNIZ, Anapuáka. [Sem título]. Instalação sonora. Rio de Janeiro: Museu de Arte do Rio, 2017.

BITTENCOURT, Julio. Ramos 13. Fotografia em C-Print. $110 \times 165 \mathrm{~cm}$. São Paulo: Galeria Lume, 2012.

BROCOS, Modesto. A Redenção de Cam. Painel a óleo sobre tela. 199 x $166 \mathrm{~cm}$, Rio de Janeiro: Museu Nacional de Belas Artes, 1895.

CARYBÉ, Hector. Sete Lendas Africanas da Bahia. Coleção de xilogravuras. 71 × $50 \mathrm{~cm}$, Rio de Janeiro: Museu de Arte do Rio, século $\mathrm{XX}$.

CLARK. Lygia. Abrigo Poético. Escultura em lata, dimensões variáveis. 1964.

FIRMEZA, Yuri. Ação 3. Fotografia (registro de performance), $90 \times 68 \mathrm{~cm}$. Coleção do artista, 2004.

FRENTE 3 DE FEVEREIRO et al. Poética do Dissenso. Instalação. Rio de Janeiro: Museu de Arte do Rio, 2013.

JAGUARIBE, Claudia. Menina na Laje: Série Entre Morros 1. Reprodução fotográfica. $180 \times 110 \mathrm{~cm}$, Rio de Janeiro: Museu de Arte do Rio, 2010. 
NETO, Ernesto. Mar revolto é coisa do passado, mar tranquilo é nunca navegado. Instalação 3744 x 5616. Rio de Janeiro: Museu de Arte do Rio, 2013.

OITICICA, Hélio. Nas quebradas. Penetrável PN28. 3,50 de altura x $4 \times$ 2 , telhas de fibrocimento, sarrafos de madeira, juta, náilon, tela de galinheiro, tijolos maciços, compensado, brita, plástico lonavinil, pregos. Rio de Janeiro: Coleção César e Cláudio Oiticica, 1979.

PATAXÓ. Pataxó Hã Hã Hãe: Índio Guerreiro. Vídeo documental. 6 min. Rio de Janeiro/ RJ, 2017.

PEREIRA, Eduardo. A Saga da Aldeia Maracanã (2006-2016). Documentário. 32 min. Rio de Janeiro/ RJ, 2017.

PROJETO MORRINHO. Morrinho. Maquete em tijolos. Rio de Janeiro: Museu de Arte do Rio, 2013.

SOUZA, Francisco de. Retrato de Tia Lúcia. Impressão sobre papel fotográfico. Rio de Janeiro: Museu de Arte do Rio, 2017.

STEWART, Ana. Carolina da praia de Mauá 2011 e 2016. Ampliação fotográfica C-Print. Rio de Janeiro: Museu de Arte do Rio, 2016.

VALENTIM, Rubem. Emblema 85. Pintura acrílica sobre tela. $35 \times 50 \mathrm{~cm}$, Rio de Janeiro: Museu de Arte do Rio, 1985.

\section{3}

\section{Exposições}

BENITES, Sandra; FREIRE, José Ribamar Bessa; LAFUENTE, Pablo; DINIZ, Clarissa. DjaGuata Porã: Rio de Janeiro indígena. Rio de Janeiro: Museu de Arte do Rio, 05/2017 - 03/2018.

CAMPOS, Marcelo; BERTH, Joice. Casa Carioca. Rio de Janeiro: Museu de Arte do Rio, 09/2020-09/2021.

DINIZ, Clarissa; CARDOSO, Rafael. Do Valongo à Favela: imaginário e periferia. Rio de Janeiro: Museu de Arte do Rio, 05/2014 - 05/2015.

EQUIPE MAR; GRUPO EMPREZA. Eu como Você. Rio de Janeiro: Museu de Arte do Rio, 05/2014 - 07/2014.

EQUIPE MAR. Mulheres na Coleção MAR. Rio de Janeiro: Museu de Arte do Rio, 11/2018 - 11/2019.

GALLOIS, Dominique Tilkin. Tempo e espaço no Amazonas: os Wajãpi. Rio de Janeiro: Museu do Índio, 2001.

GÓMEZ, Pedro Pablo; MIGNOLO, Walter. Estéticas Decoloniales. Bogotá, Colômbia: Museo de Arte Moderno de Bogotá, 2010. 
GUERRERO, Inti; ROMERO, Carlos Maria. Josephine Baker e Le Corbusier - Um caso Transatlântico. Rio de Janeiro: Museu de Arte do Rio, 04/2014 - 08/2014.

HERKENHOFF, Paulo. 24a Bienal de São Paulo: Bienal da Antropofagia. São Paulo: Pavilhão da Bienal - Parque do Ibirapuera, 1998.

HERKENHOFF, Paulo; CONDURU, Roberto. Vontade Construtiva na Coleção Fadel. Rio de Janeiro: Museu de Arte do Rio, 03/2013 10/2013.

HERKENHOFF, Paulo; DINIZ, Clarissa; FIRMEZA, Yuri. Yuri Firmeza: Turvações Estratigráficas. Rio de Janeiro: Museu de Arte do Rio, 09/2013 $-12 / 2013$.

HERKENHOFF, Paulo; DINIZ, Clarissa. O Abrigo e o Terreno: arte e sociedade no Brasil I. Rio de Janeiro: Museu de Arte do Rio, 03/2013 07/2013.

HERKENHOFF, Paulo; DINIZ, Clarissa. Pernambuco Experimental. Rio de Janeiro: Museu de Arte do Rio, 12/2013 - 03/2014.

HERKENHOFF, Paulo; GURAN, Milton. Linguagens do Corpo Carioca [a vertigem do Rio]. Rio de Janeiro: Museu de Arte do Rio, 06/2016 $10 / 2016$.

HERKENHOFF, Paulo. ImagináRIO. Rio de Janeiro: Museu de Arte do Rio, 08/2013 - 04/2014.

HERKENHOFF, Paulo. Pororoca - A Amazônia no MAR. Rio de Janeiro: Museu de Arte do Rio, 09/2014 - 11/2014.

KAZ, Leonel; MIGLIACCIO, Luciano. O Colecionador: Arte brasileira e internacional na coleção Jean Boghici. Rio de Janeiro: Museu de Arte do Rio, 03/2013 - 09/2013.

LAGNADO, Lisette. 27ª Bienal de São Paulo: Como Viver Junto. São Paulo: Pavilhão da Bienal - Parque do Ibirapuera, 2006.

LAGROU, Els. No Caminho da Miçanga: Um mundo que se faz de contas. Rio de Janeiro: Museu do Índio, 2015.

LASCH, Pedro. Black Mirror. Carolina do Norte, Estados Unidos: Nasher Museum of Art, 2008.

LOPES, Nei; SALLES, Evandro; DINIZ, Clarissa; CAMPOS, Marcelo. 0 Rio do Samba: resistência e reinvenção. Rio de Janeiro: Museu de Arte do Rio, 04/2018 - 04/2019.

MARTíN, Jean-Hubert. Magiciens de la Terre. Paris, França: Centre Georges Pompidou/ Grande halle de la Villete, 1989. 
MARTINS, Carlos; CARDOSO, Rafael. Rio de Imagens. Rio de Janeiro: Museu de Arte do Rio, 03/2013-07/2013.

PUCU, Izabela; CAMARGOS, Bruna. A Pequena África e o MAR de Tia Lúcia. Rio de Janeiro: Museu de Arte do Rio, 11/2018 - 03/2019.

SALLES, Evandro. Dentro: Programa Sala de Encontro. Rio de Janeiro: Museu de Arte do Rio, 03/2017 - 03/2018.

SALLES, Evandro. Feito Poeira ao Vento: Fotografia na Coleção MAR. Rio de Janeiro: Museu de Arte do Rio, 08/2017 - 08/2018.

SALLES, Evandro; TEIXEIRA, Francisco Carlos; TERRA, Fernanda; CAMPOS, Marcelo; QUINTELLA, Poliana. O Rio dos Navegantes. Rio de Janeiro: Museu de Arte do Rio, 05/2019-03/2020.

WILSON, Fred. Mining the Museum. Baltimore, Estados Unidos: Maryland Historical Society, 1992.

WILSON, Fred. Site unseen: Dwellings of the Demon. Gotemburgo, Suécia: Museum of World Culture, 1992.

\section{4}

\section{Vídeos do YouTube}

MUSEU DE ARTE DO RIO. Abertura da exposição "A Pequena África e o MAR de Tia Lucia". 05 de dez. 2018. (3m16s). Disponível em: https://youtu.be/S2hV9tqenQc. Acesso em: 06 jun. 2020.

MUSEU DE ARTE DO RIO. Abertura da exposição "O Rio dos Navegantes". 10 de jul. 2019. (5m43s). Disponível em: https://youtu.be/fgrq3356adQ. Acesso em: 06 jun. 2020.

MUSEU DE ARTE DO RIO. Abertura da exposição "Pardo é papel", de Maxwell Alexandre. 11 de dez. 2019. (4m16s). Disponível em: https://youtu.be/0Dg89gHA3Jc. Acesso em: 06 jun. 2020.

MUSEU DE ARTE DO RIO. Abertura da exposição "Rosana Paulino: A Costura da Memória". 12 de jun. 2019. (7m10s). Disponível em: https://youtu.be/3aGA0E3QadA. Acesso em: 06 jun. 2020.

MUSEU DE ARTE DO RIO. Abertura da exposição "Rua!". 27 de fev. 2020. (3m32s). Disponível em: https://youtu.be/-OMz2zo6S5Q. Acesso em: 06 jun. 2020.

MUSEU DE ARTE DO RIO. Abertura da Spider (Aranha), de Louise Bourgeois, na Coleção Itaú Cultural. 04 de dez. 2019. (4m20s). Disponível em: https://youtu.be/kMDP0zJWPGk. Acesso em: 06 jun. 2020.

MUSEU DE ARTE DO RIO. Abertura de "Da abstração ao neoconcretismo: uma homenagem a Décio Vieira". 10 de mai. 2017. 
(26m58s). Disponível em: https://youtu.be/i3P-sexfMfQ. Acesso em: 06 jun. 2020.

MUSEU DE ARTE DO RIO. Abertura 'UóHol', de Rafael BQueer + Batalha de Close. 24 de jan. 2020. (4m27s). Disponível em: https://youtu.be/JaiXU80KMUU. Acesso em: 06 jun. 2020.

MUSEU DE ARTE DO RIO. Ação educativa - especial O Abrigo e o Terreno. 05 de ago. 2013. (08m15s). Disponível em: https://youtu.be/YtmNRQckkO4. Acesso em: 12 jan. 2020.

MUSEU DE ARTE DO RIO. ARTE DEMOCRACIA UTOPIA | Abertura da exposição. 23 de out. 2018. (5m21s). Disponível em: https://youtu.be/kH13J0UGTuo. Acesso em: 06 jun. 2020.

MUSEU DE ARTE DO RIO. Café com Vizinhos | Dezembro 2017. 11 de jun. 2018. (02m18s). Disponível em: https://youtu.be/RQxAzV_kAR8. Acesso em 13 jul. 2020.

MUSEU DE ARTE DO RIO. Café com Vizinhos do MAR - Dezembro. 12 de jan. 2015. (44m21s). Disponível em: https://youtu.be/Fun5AFNMPgs. Acesso em 13 jul. 2020.

MUSEU DE ARTE DO RIO. Carioca Itinerante - Atividade com alunos do GEA. 12 de jan. 2015. (08m18s). Disponível em: https://youtu.be/EJuBAzzsOLs. Acesso em: 22 jan. 2020.

MUSEU DE ARTE DO RIO. Carioca Itinerante - Conversa de Galeria. 12 de jan. 2015. (12m57s). Disponível em: https://youtu.be/enlnF5ObHbE. Acesso em: 22 jan. 2020. Acesso em: 22 jan. 2020.

MUSEU DE ARTE DO RIO. Carioca Itinerante - Depoimentos de Bruno Faria e Clarissa Diniz. 12 de jan. 2015. (06m59s). Disponível em: https://youtu.be/L5nZU-ZXIDA. Acesso em: 22 jan. 2020.

MUSEU DE ARTE DO RIO. Carioca Itinerante - Depoimento de Robson Letiere. 12 de jan. 2015. (10m49s). Disponível em: https://youtu.be/5fDkx5FymdA. Acesso em: 22 jan. 2020.

MUSEU DE ARTE DO RIO. Casa Carioca - Live com os curadores Marcelo Campos e Joice Berth. 22 de mai. 2020. (58m53s). Disponível em: https://youtu.be/Yw-aho_rFTc. Acesso em: 15 ago. 2020.

MUSEU DE ARTE DO RIO. Casa Carioca por Alan Fontes. 10 de ago. 2020. (3m22s). Disponível em: https://youtu.be/i2ZUl1Rz9iM. Acesso em: 16 ago. 2020.

MUSEU DE ARTE DO RIO. Casa Carioca por Ana Clara Tito. 15 de jun. 2020. (2m16s). Disponível em: https://youtu.be/v6zW8Ltgjp4. Acesso em: 16 ago. 2020. 
MUSEU DE ARTE DO RIO. Casa Carioca por Ana Hortides. 03 de ago. 2020. (1m49s). Disponível em: https://youtu.be/VNDwAuJOlKc. Acesso em: 16 ago. 2020.

MUSEU DE ARTE DO RIO. Casa Carioca por Bruno Portella. 17 de ago. 2020. (1m43s). Disponível em: https://youtu.be/tL1G8y1UYOo. Acesso em: 17 ago. 2020.

MUSEU DE ARTE DO RIO. Casa Carioca por Diambe. 29 de jun. 2020. (2m46s). Disponível em: https://youtu.be/hN-gpZcBhoU. Acesso em: 16 ago. 2020.

MUSEU DE ARTE DO RIO. Casa Carioca por Érica Magalhães. 01 de jun. 2020. (2m10s). Disponível em: https://youtu.be/eciDI-h3tfk. Acesso em: 16 ago. 2020.

MUSEU DE ARTE DO RIO. Casa Carioca por Gilson Plano. 27 de abr. 2020. (1m50s). Disponível em: https://youtu.be/HJt_wHsMtqw. Acesso em: 16 ago. 2020.

MUSEU DE ARTE DO RIO. Casa Carioca por Marcelo Campos. 20 de abr. 2020. (2m20s). Disponível em: https://youtu.be/ohhqVaikS8E. Acesso em: 16 ago. 2020.

MUSEU DE ARTE DO RIO. Casa Carioca por Maria Fernanda Lucena. 27 de jul. 2020. (1m57s). Disponível em: https://youtu.be/e8_TMvc1XTk. Acesso em: 16 ago. 2020.

MUSEU DE ARTE DO RIO. Casa Carioca por Mariana Par. 22 de jun. 2020. (2m08s). Disponível em: https://youtu.be/tb1k5p3YpBc. Acesso em: 16 ago. 2020.

MUSEU DE ARTE DO RIO. Casa Carioca por Maxim Malhado. 20 de jul. 2020. (1m49s). Disponível em: https://youtu.be/zGjyBFgG5Fs. Acesso em: 16 ago. 2020.

MUSEU DE ARTE DO RIO. Casa Carioca por max wílà morais. 04 de mai. 2020. (3m26s). Disponível em: https://youtu.be/JqoBFny90sw. Acesso em: 16 ago. 2020.

MUSEU DE ARTE DO RIO. Casa Carioca por Millena Lízia. 11 de mai. 2020. (1m56s). Disponível em: https://youtu.be/2K8hcChM6HI. Acesso em: 16 ago. 2020.

MUSEU DE ARTE DO RIO. Casa Carioca por Mulambö. 25 de mai. 2020. (1m51s). Disponível em: https://youtu.be/DQkYbGB4bkM. Acesso em: 16 ago. 2020.

MUSEU DE ARTE DO RIO. Casa Carioca por Rafael BQueer. 08 de jun. 2020. (2m57s). Disponível em: https://youtu.be/bDX3EazxgjU. Acesso em: 16 ago. 2020. 
MUSEU DE ARTE DO RIO. Casa Carioca por Raquel Nava. 13 de jul. 2020. (2m20s). Disponível em: https://youtu.be/Yw7_zsB9Wx0. Acesso em: 16 ago. 2020.

MUSEU DE ARTE DO RIO. Casa Carioca por Yhuri Cruz. 18 de mai. 2020. (1m54s). Disponível em: https://youtu.be/g8h72d3Xc44. Acesso em: 16 ago. 2020.

MUSEU DE ARTE DO RIO. Casa Carioca por Yuri Firmeza. 06 de jul. 2020. (2m16s). Disponível em: https://youtu.be/jJePaKDHido. Acesso em: 16 ago. 2020.

MUSEU DE ARTE DO RIO. Construção em diálogo - Dja Guata Porã. 7 de mar. 2017. (3h29m33s). Disponível em: https://youtu.be/8ljDnheYaNO. Acesso em: 23 jun. 2020.

MUSEU DE ARTE DO RIO. Conversa de Galeria com Ernesto Neto Especial de encerramento 0 Abrigo e o Terreno. 05 de ago. 2013. (30m37s). Disponível em: https://youtu.be/VNTOGOZv1GE. Acesso em 29 out. 2019.

MUSEU DE ARTE DO RIO. Conversa de Galeria com Livia Flores encerramento 0 Abrigo e o Terreno. 01 de ago. 2013. (12m59s). Disponível em: https://youtu.be/38gCUCOOzY0. Acesso em 11 jan. 2020.

MUSEU DE ARTE DO RIO. Conversa de Galeria com Vizinho Convidado. 12 de nov. 2018. (36m42s). Disponível em: https://youtu.be/vquNjs3uwik. Acesso em 13 jul. 2020.

MUSEU DE ARTE DO RIO. Conversa de Galeria da exposição A cor do Brasil. 11 de ago. 2016. (23m49s). Disponível em: https://youtu.be/BOsPFHwlYC0. Acesso em: 23 jun. 2020.

MUSEU DE ARTE DO RIO. Conversa de Galeria | Dja Guata Porã: Rio de Janeiro indígena | Parte 1. 29 de jun. 2017. (52m30s). Disponível em: https://youtu.be/fuFrz4kx4Go. Acesso em 20 jul. 2020.

MUSEU DE ARTE DO RIO. Conversa de Galeria | Dja Guata Porã: Rio de Janeiro indígena | Parte 2. 03 de jul. 2017. (1h35m03s). Disponível em: https://youtu.be/wGgf17uWpEk. Acesso em 20 jul. 2020.

MUSEU DE ARTE DO RIO. Conversa de Galeria Especial com Vizinhos Convidados. 24 de mar. 2016. (44m23s). Disponível em: https://youtu.be/JtafdT5MJNO. Acesso em: 13 jul. 2020.

MUSEU DE ARTE DO RIO. Conversa de Galeria Linguagens do corpo carioca [a vertigem do Rio]. 15 de jun. 2016. (45m30s). Disponível em: https://youtu.be/OJ57tJrZHeQ. Acesso em: 06 jul. 2020.

MUSEU DE ARTE DO RIO. Conversa de Galeria - Pororoca: A Amazônia no MAR. 27 de out. 2014. (2h23m02s). Disponível em: https://youtu.be/4zXKzB1ynaU. Acesso em 06 jul. 2020. 
MUSEU DE ARTE DO RIO. Conversa de galeria | Vizinho Convidado. 21 de jun. 2018. (59m05s). Disponível em: https://youtu.be/KjXkc-b5XjU. Acesso em: 14 jul. 2020.

MUSEU DE ARTE DO RIO. Curso Arte, ação e pensamento anticoloniais - Aula com Rosana Paulino. 10 de out. 2019. (2h45m42s). Disponível em: https://youtu.be/sww6jN3_yyg. Acesso em: 01 fev. 2020. Acesso em: 01 fev. 2020.

MUSEU DE ARTE DO RIO. Curso Arte, ação e pensamento anticoloniais - Como escutar o Falatório?. 30 de set. 2019. (2h30m31s). Disponível em: https://youtu.be/PbDI35yN7Ro. Acesso em: 31 jan. 2020.

MUSEU DE ARTE DO RIO. Curso Arte, ação e pensamento anticoloniais - Estamira: corpos que pesam, vidas que importam. 10 de out. 2019. (2h41m54s). Disponível em: https://youtu.be//47NLCARm1M. Acesso em: 01 fev. 2020.

MUSEU DE ARTE DO RIO. Curso Arte, ação e pensamento anticoloniais - Monólogo com Cyda Moreno. 10 de out. 2019. (1h59m16s). Disponível em: https://youtu.be/gVQAVrzCwwc. Acesso em: 02 fev. 2020.

MUSEU DE ARTE DO RIO. Curso Arte, ação e pensamento anticoloniais - Por uma práxis anticolonial, com Claudia Miranda. 30 de set. 2019. (2h19m). Disponível em: https://youtu.be/BGWR3O8JG68. Acesso em: 31 jan. 2020.

MUSEU DE ARTE DO RIO. Curso de História da Arte Brasileira :: Claudio Paiva | O colecionador de linhas - Aula 1. 28 de jun. 2018. (1h38m28s). Disponível em: https://youtu.be/M3FtrDALnOI. Acesso em: 21 mai. 2020.

MUSEU DE ARTE DO RIO. Curso de História da Arte Brasileira :: Claudio Paiva | O colecionador de linhas - Aula 2. 29 de jun. 2018. (2h02m31s). Disponível em: https://youtu.be/QAOv2MOuBml. Acesso em: 21 mai. 2020.

MUSEU DE ARTE DO RIO. Curso de História da Arte Brasileira :: Feito poeira ao vento | fotografia na coleção MAR - Aula 1. 19 de jun. 2018. (1h48m20s). Disponível em: https://youtu.be/YGrzbymrLVw. Acesso em: 22 mai. 2020.

MUSEU DE ARTE DO RIO. Curso de História da Arte Brasileira :: Feito poeira ao vento | fotografia na coleção MAR - Aula 2. 19 de jun. 2018. (2h28m37s). Disponível em: https://youtu.be/wp6RVOhn0sl. Acesso em: 22 mai. 2020.

MUSEU DE ARTE DO RIO. Curso Mulheres, Arte e Ciência :: Diálogos sobre Estação Mulheres com Niara do Sol. 06 de jul. 2017. 
(1h44m26s). Disponível em: https://youtu.be/nazpjWqPTWM. Acesso em: 25 jul. 2020.

MUSEU DE ARTE DO RIO. Curso Mulheres, Arte e Ciência | Diálogos sobre Estação Mulheres em "Dja Guata Porã" | Parte 01. 27 de jul. 2017. (1h12m48s). Disponível em: https://youtu.be/tBgRxyVj0xA. Acesso em: 24 jul. 2020.

MUSEU DE ARTE DO RIO. Curso Mulheres, Arte e Ciência | Diálogos sobre Estação Mulheres em "Dja Guata Porã" | Parte 02. 28 de jul. 2017. (1h37m57s). Disponível em: https://youtu.be/ZMx7tYlsdkl. Acesso em: 24 jul. 2020.

MUSEU DE ARTE DO RIO. Debate de encerramento da exposição 0 Abrigo e o Terreno. 06 de ago. 2013. (02h05m01s). Disponível em: https://youtu.be/ccqO_ywk1cY. Acesso em: 20 nov. 2019.

MUSEU DE ARTE DO RIO. Desmontagem da obra "Where to?", de Marcio Almeida. 06 de ago. 2013. (13m38s). Disponível em: https://youtu.be/vEXA9kUFbV4. Acesso em: 20 nov. 2019.

MUSEU DE ARTE DO RIO. Dja Guata Porã :: Curso de História da Arte Brasileira - Aula 1. 17 de jan. 2018. (1h51m15s). Disponível em: https://youtu.be/BqV-5F1dVtY. Acesso em: 26 jul. 2020.

MUSEU DE ARTE DO RIO. Dja Guata Porã :: Curso de História da Arte Brasileira - Aula 2. 29 de jan. 2018. (2h03m37s). Disponível em: https://youtu.be/4x_e8Y-c3hM. Acesso em 26 jul. 2020.

MUSEU DE ARTE DO RIO. Dja Guata Porã :: Curso de História da Arte Brasileira - Aula 3. 29 de jan. 2018. (1h21m51s). Disponível em: https://youtu.be/sV5bnL7qhts. Acesso em 27 jul. 2020.

MUSEU DE ARTE DO RIO. Entrevista com Márcio Almeida - Museu de Arte do Rio. 17 de mai. 2013. (03m43s). Disponível em: https://youtu.be/HUIWaDNrsUw. Acesso em: 20 nov. 2019.

MUSEU DE ARTE DO RIO. MAR na Academia :: Museus e Emergências Contemporâneas | Dja Guata Porã Dia 01 Parte 01. 27 de set. 2017. (1h34m09s). Disponível em: https://youtu.be/izVtOAp7SKw. Acesso em: 21 jul. 2020.

MUSEU DE ARTE DO RIO. MAR na Academia :: Museus e Emergências Contemporâneas | Dja Guata Porã Dia 01 Parte 02. 27 de set. 2017. (1h41m37s). Disponível em: https://youtu.be/izVtOAp7SKw. Acesso em: 21 jul. 2020.

MUSEU DE ARTE DO RIO. MAR na Academia :: Museus e Emergências Contemporâneas | Dja Guata Porã Dia 02 Parte 01. 27 de set. 2017. (1h31m28s). Disponível em: https://youtu.be/asoFdnGjgE8. Acesso em: 22 jul. 2020. 
MUSEU DE ARTE DO RIO. MAR na Academia :: Museus e Emergências Contemporâneas | Dja Guata Porã Dia 02 Parte 02. 27 de set. 2017. (1h28m43s). Disponível em: https://youtu.be/_KZNbLs029o. Acesso em: 22 jul. 2020.

MUSEU DE ARTE DO RIO. MAR na Academia :: Museus e Emergências Contemporâneas | Dja Guata Porã Dia 02 Parte 03. 28 de set. 2017. (1h10m54s). Disponível em: https://youtu.be/k1wb_leR_IM. Acesso em: 22 jul. 2020.

MUSEU DE ARTE DO RIO. MAR na Academia :: Museus e Emergências Contemporâneas | Dja Guata Porã Dia 02 Parte 04. 28 de set. 2017. (50m14s). Disponível em: https://youtu.be/LRe0qWRNFh0. Acesso em: 22 jul. 2020.

MUSEU DE ARTE DO RIO. MAR na Academia :: Museus e Emergências Contemporâneas | Dja Guata Porã Dia 03 Parte 01. 28 de set. $2017 . \quad$ (1h15m03s). Disponível em: https://youtu.be/G4j2egQJCGM. Acesso em: 23 jul. 2020.

MUSEU DE ARTE DO RIO. MAR na Academia :: Museus e Emergências Contemporâneas | Dja Guata Porã Dia 03 Parte 02. 28 de set. 2017. (1h05m01s). Disponível em: https://youtu.be/AyemZid3hIQ. Acesso em: 23 jul. 2020.

MUSEU DE ARTE DO RIO. MAR na Academia :: Museus e Emergências Contemporâneas | Dja Guata Porã Dia 03 Parte 03. 28 de set. 2017. (1h20m33s). Disponível em: https://youtu.be/3YLBFVmA1Wc. Acesso em: 23 jul. 2020.

MUSEU DE ARTE DO RIO. MAR na Academia :: Museus e Emergências Contemporâneas | Dja Guata Porã Dia 03 Parte 04. 28 de set. 2017. (1h17m32s). Disponível em: https://youtu.be/bQceUg8ZZQA. Acesso em: 23 jul. 2020.

MUSEU DE ARTE DO RIO. MAR na Rua - EP 1 "O MAR olha para o Rio", com Pâmela Carvalho. 14 de nov. 2019. (3m35s). Disponível em: https://youtu.be/xr7ePj_GvrY. Acesso em: 03 ago. 2020.

MUSEU DE ARTE DO RIO. MAR na Rua - EP 2 "Representação de si Representação do outro", com Mauricio Hora. 28 de nov. 2019. (3m21s). Disponível em: https://youtu.be/3HEiy2WkoqE. Acesso em: 03 ago. 2020.

MUSEU DE ARTE DO RIO. MAR na Rua - EP 3 "Esqueletos no subsolo", com Merced Guimarães. 04 de dez. 2019. (3m09s). Disponível em: https://youtu.be/_GCrdxjTamk. Acesso em: 03 ago. 2020.

MUSEU DE ARTE DO RIO. MAR na Rua - EP 4 "O que é preciso para fazer arte", com Mulambö. 12 de dez. 2019. (3m10s). Disponível em: https://youtu.be/OuroCP-F0vo. Acesso em: 03 ago. 2020. 
MUSEU DE ARTE DO RIO. MAR na Rua - EP 5 "Cosmovisões Negras", com Mãe Celina de Xangô. 19 de dez. 2019. (3m29s). Disponível em: https://youtu.be/wTdw7N_U9JI. Acesso em: 03 ago. 2020.

MUSEU DE ARTE DO RIO. Ofícios e Saberes da Região com Eliana Rosa. 06 de mai. 2018. (16m33s). Disponível em: https://youtu.be/1AeqPXMcHDA. Acesso em: 13 jul. 2020.

MUSEU DE ARTE DO RIO. O Rio do Samba | Abertura da exposição. 15 de mai. 2018. (4m30s). Disponível em: https://youtu.be/rnid-MFSiZo. Acesso em: 06 jun. 2020.

MUSEU DE ARTE DO RIO. Palestra com Clarissa Diniz - Arte: História, Crítica e Curadoria (PUC/SP). 12 de dez. 2014. (1h13m57s). Disponível em: https://youtu.be/KPWOIN5rDcw. Acesso em: 21 mar. 2020.

MUSEU DE ARTE DO RIO. Palestra com Gleyce Heitor - Arte: História, Crítica e Curadoria (PUC/SP). 12 de dez. 2014. (1h27m14s). Disponível em: https://youtu.be/dE-bcEiXedM. Acesso em: 22 mar. 2020.

MUSEU DE ARTE DO RIO. Palestra com Paulo Herkenhoff - Arte: História, Crítica e Curadoria (PUC/SP). 08 de dez. 2014. (1h29m02s). Disponível em: https://youtu.be/xls-a3sPTZ8. Acesso em: 20 mar. 2020.

MUSEU DE ARTE DO RIO. Percursos Mediados - O Rio dos Navegantes | EP 1 - Apresentação. 06 de jul. 2020. (4m15s). Disponível em: https://youtu.be/Z-2GUmw_wlw. Acesso em: 04 ago. 2020.

MUSEU DE ARTE DO RIO. Percursos Mediados - O Rio dos Navegantes | EP 2 - O contemporâneo atemporal. 13 de jul. 2020. (4m13s). Disponível em: https://youtu.be/IGvTNiFXhcs. Acesso em: 04 ago. 2020.

MUSEU DE ARTE DO RIO. Percursos Mediados - $O$ Rio dos Navegantes | EP 3 - Relações entre Claudia Jaguaribe e Rosana Paulino. 20 de jul. 2020. (8m15s). Disponível em: https://youtu.be/V6UQYMBpAuc. Acesso em: 04 ago. 2020.

MUSEU DE ARTE DO RIO. Percursos Mediados - O Rio dos Navegantes | EP 4 - O amor mora em Ramos. 27 de jul. 2020. (2m41s). Disponível em: https://youtu.be/9bIS-d-WREk. Acesso em: 04 ago. 2020.

MUSEU DE ARTE DO RIO. Percursos Mediados - 0 Rio dos Navegantes | EP 5 - Contra-maré. 03 de ago. 2020. (1m14s). Disponível em: https://youtu.be/xmSsTbw08tA. Acesso em: 04 ago. 2020.

MUSEU DE ARTE DO RIO. Projeto Qual é a graça? 15 de out. 2014. (09m56s). Disponível em: https://youtu.be/k2qX99ddC1g. Acesso em: 08 out. 2019. 
MUSEU DE ARTE DO RIO. Reinauguração da Biblioteca e Centro de Documentação MAR. 01 de out. 2019. (5m17s). Disponível em: https://youtu.be/c7w3zdvyg_4. Acesso em: 20 fev. 2020.

MUSEU DE ARTE DO RIO. Seminário "O Terceiro Setor na Gestão da Cultura"| Pt. 1. 29 de mar. 2017. (2h38m52s). Disponível em: https://youtu.be/ZRdTNra3MpU. Acesso em: 15 fev. 2020.

MUSEU DE ARTE DO RIO. Seminário "O Terceiro Setor na Gestão da Cultura"| Pt. 2. 29 de mar. 2017. (2h07m21s). Disponível em: https://youtu.be/GsLHHZcDcRE. Acesso em: 16 fev. 2020.

MUSEU DE ARTE DO RIO. Seminário "O Terceiro Setor na Gestão da Cultura"| Pt. 3. 29 de mar. 2017. (2h09m46s). Disponível em: https://youtu.be/OkDLJpX4ymY. Acesso em: 17 fev. 2020.

MUSEU DE ARTE DO RIO. Tunga | Abertura da exposição. 20 de jul. 2018. (4m22s). Disponível em: https://youtu.be/1dWYVXD1qS4. Acesso em: 06 jun. 2020. 